CORVINUS E G Y E T E M

Élelmiszertudományi Kar
Budapesti Corvinus Egyetem

Élelmiszertudományi Kar

Élelmiszeripari Műveletek és Gépek Tanszék

\title{
MEMBRÁN- ÉS OZMOTIKUS DESZTILLÁCIÓ ÉLELMISZERIPARI ÉS KÖRNYEZETVÉDELMI VONATKOZÁSAI
}

Doktori (PhD) értekezés

Készítette: Rácz Gábor

Témavezető: Dr. Vatai Gyula

Társtémavezető: Dr. Kovács Zoltán

Budapest 


\section{A doktori iskola}

megnevezése: Élelmiszertudományi Doktori Iskola

tudományága: Élelmiszertudományok

vezetője:

Dr. Felföldi József

Egyetemi tanár, $\mathrm{PhD}$

BUDAPESTI CORVINUS EGYETEM, Élelmiszertudományi Kar

Fizika-Automatika Tanszék

Témavezető:

Dr. Vatai Gyula

Egyetemi tanár, DSc

BUDAPESTI CORVINUS EGYETEM, Élelmiszertudományi Kar

Élelmiszeripari Műveletek és Gépek Tanszék

Társtémavezető: Dr. Kovács Zoltán

Egyetemi docens, $\mathrm{PhD}$

BUDAPESTI CORVINUS EGYETEM, Élelmiszertudományi Kar

Élelmiszeripari Műveletek és Gépek Tanszék

A jelölt a Budapesti Corvinus Egyetem Doktori Szabályzatában elöírt valamennyi feltételnek eleget tett, az értekezés mühelyvitájában elhangzott észrevételeket és javaslatokat az értekezés átdolgozásakor figyelembe vette, ezért az értekezés nyilvános vitára bocsátható. 
A Budapesti Corvinus Egyetem Élettudományi Területi Doktori Tanácsának 2015. március 13-i határozatában a nyilvános vita lefolytatására az alábbi bíráló Bizottságot jelölte ki:

\title{
BÍRÁLÓ BIZOTTSÁG:
}

\author{
Elnöke \\ Biacs Péter, DSc
}

Tagjai

Bélafiné Bakó Katalin, DSc

Simonné Sarkadi Livia, DSc

Stégerné Máté Mónika, $\mathrm{PhD}$

Rektor Attila, PhD

\section{Opponensek}

Hodúr Cecília, DSc

Nemestóthy Nándor, PhD

Titkár

Bánvölgyi Szilvia, PhD 


\section{TARTALOMJEGYZÉK}

JELÖLÉSEK, RÖVIDÍTÉSEK JEGYZÉKE

1. BEVEZETÉS

2. IRODALMI ÁTTEKINTÉS. 9

2.1. A membrán- és ozmotikus desztilláció alapjai .............................................................. 9

2.2. A membrán- és ozmotikus desztilláció modellezése ....................................................... 14

2.2.1. A membrán- és ozmotikus desztilláció anyagátbocsátása .......................................... 14

2.2.2. Müveleti paraméterek hatása ............................................................................ 16

2.2.2.1. Betáplálás hőmérsékletének és a hőmérséklet-különbségnek a hatása ........................ 16

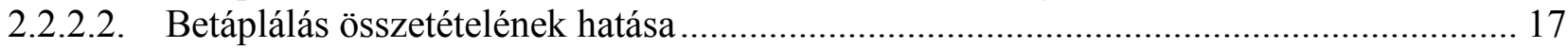

2.2.2.3. Betáplálás áramlási sebességének hatása ............................................................ 18

2.2.3. Membránra jellemző paraméterek hatása .............................................................. 18

2.2.3.1. Folyadék behatolási nyomás (Liquid entry pressure (LEP)) .................................... 19

2.2.3.2. A membrán pórusok nedvesedésének hiszterézises jelensége .................................... 21

2.2.3.3. LEP mérése statikus módszerrel az irodalomban ................................................. 22

2.2.4. A membrán- és ozmotikus desztilláció alkalmazási területei ..................................... 25

2.2.4.1. Sós víz, tengervíz sótalanítás, talajvíztisztítás ................................................. 25

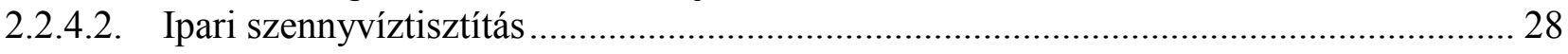

2.2.4.3. Vegyipar, fermentációs eljárások, gyógyszeripar ................................................. 29

2.2.4.4. Olaj-víz emulzió szétválasztása ....................................................................... 33

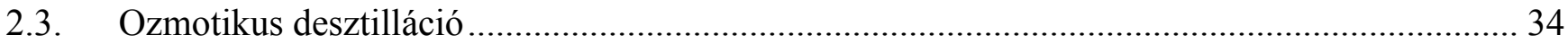

2.3.1 Élelmiszer-adalékanyagok ozmotikus ágensként.................................................... 36

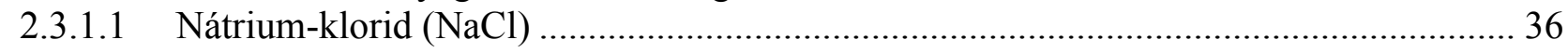

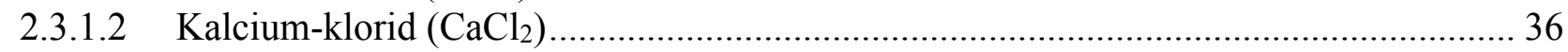

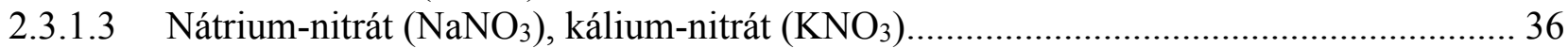

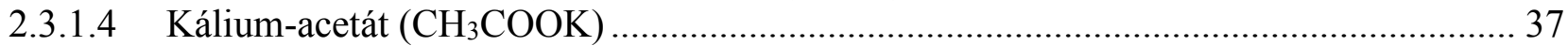

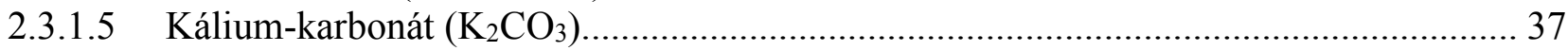

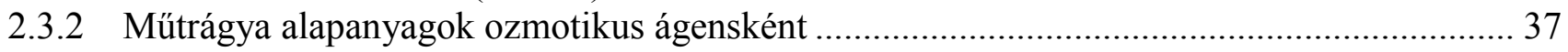

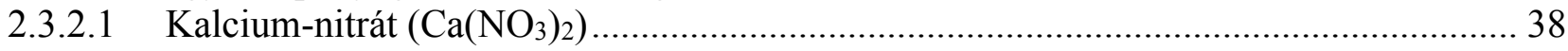

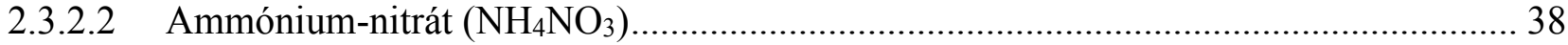

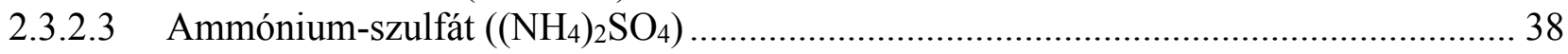

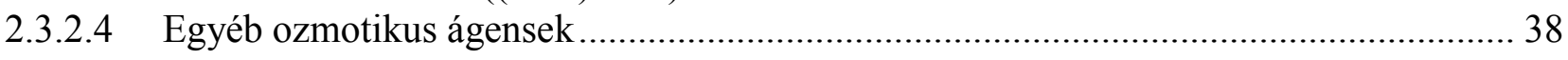

2.4 Többlépcsős membrános eljárás hatóanyagok kinyerésére ................................................. 39

2.5 A meggy és annak egészségmegőrző tulajdonságai ................................................. 40

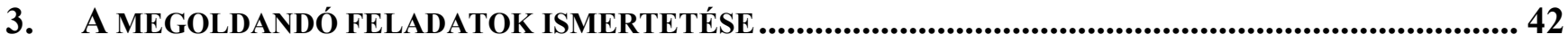

3.1. A membránpórus-nedvesedés jelenségének vizsgálta membrándesztilláció esetén .................. 42

3.2. Olaj-víz emulzió szétválasztása vákuum-membrándesztilláció segítségével ..........................42

3.3. Többlépcsős membrános eljárás zsályahatóanyagok kinyerésére .......................................43

3.4. Meggysürítmény előállítása kapcsolt membrános müvelettel, új ozmotikus oldatokkal............43 


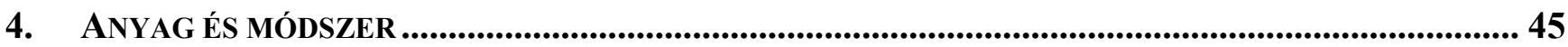

4.1. A membránpórus-nedvesedés jelelenségéhez kapcsolódó kísérleti módszerek ....................... 45

4.1.1. Kísérleti berendezés összeállítása és az $\mathrm{LEP}_{\mathrm{w}}$ mérése - statikus módszer ...................... 45

4.1.2. Kísérleti berendezés összeállítása és az LEP $_{\mathrm{w}}$ mérése - dinamikus módszer................... 47

4.1.2.1. DCMD elrendezés felépítése és az $\mathrm{LEP}_{\mathrm{w}}$ mérése .................................................. 47

4.1.2.2. VMD elrendezés felépítése és LEP $_{\mathrm{w}}$ mérése ....................................................... 49

4.1.3. Nedvesedett membránpórusok regenerálásának lehetőségei ........................................ 51

4.1.3.1. Regenerálás magas hőmérsékleten............................................................... 51

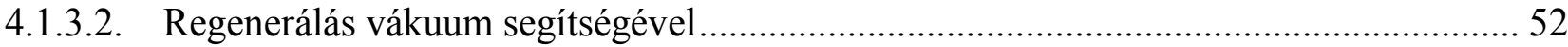

4.2. Olaj-víz $(\mathrm{O} / \mathrm{V})$ emulzió szétválasztása vákuum-membrándesztilláció segítségével.................. 53

4.2.1. LEP érték változásának vizsgálata a model $\mathrm{O} / \mathrm{V}$ emulzió összetételének függvényében

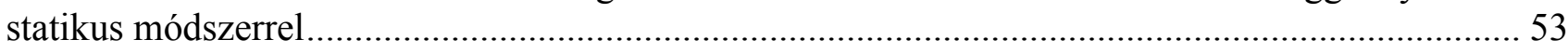

4.2.2. LEP érték változásának vizsgálata a model $\mathrm{O} / \mathrm{V}$ emulzió összetételének függvényében

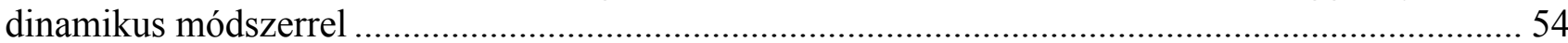

4.2.3. $\mathrm{O} / \mathrm{V}$ emulzió szétválasztásának vizsgálata vákuum-membrándesztillációs berendezéssel 55

4.3. Anyagok és módszerek többlépcsős membrános eljárással való zsályahatóanyagok kinyerésére .

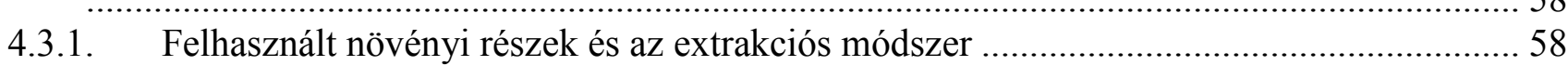

4.3.2. Alkalmazott membrán müveletek ........................................................................ 58

4.3.3. Alkalmazott analitikai módszerek a bioaktív komponensek vizsgálatára ........................ 61

4.3.3.1. Spektrofotometriás eljárások az összes polifenol tartalom, az összes flavonoid tartalom és antioxidáns kapacitás meghatározásához .................................................................. 61

4.3.3.2. Polifenolok vizsgálata nagy teljesítményü folyadékkromatográfiás analitikai módszerrel

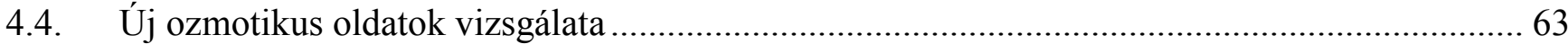

4.4.1. Különböző ozmotikus oldatok hatékonyságának összehasonlítása ................................ 63

4.4.2. Kiválasztott ozmotikus oldat esetén a desztillátum fluxusára ható müveleti paraméterek

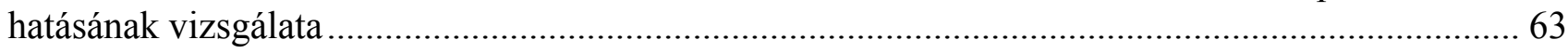

4.5. Meggysürítmény kíméletes sürítése kapcsolt membrános eljárással .......................................6 65

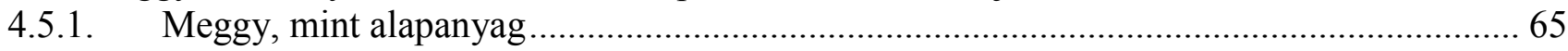

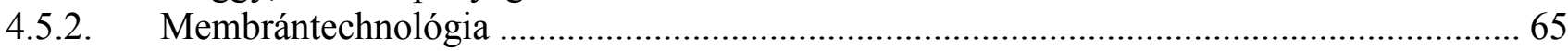

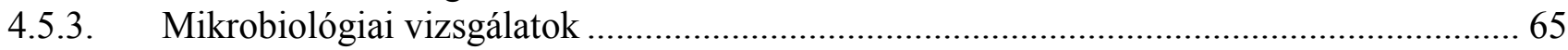

4.5.3.1. Összcsíraszám meghatározása lemezöntéssel .................................................... 66

4.5.3.2. Ozmofil élesztő- és xerofil penészgombaszám meghatározás lemezöntéssel ................ 66

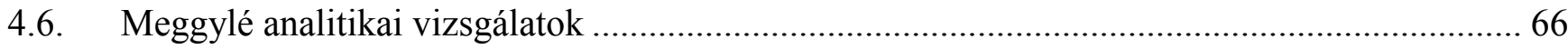

4.6.1. Meggylé antioxidáns kapacitása FRAP módszer szerint .............................................. 66

5. EREDMÉNYEK ................................................................................................................................... 67

5.1. A membránpórus-nedvesedés jelenségéhez kapcsolódó kísérleti eredmények .......................67

5.1.1. $\quad$ LEP $_{\mathrm{w}}$ kísérleti meghatározásának eredményei statikus módszerrel.................................6 67

5.1.2. $\quad \mathrm{LEP}_{\mathrm{w}}$ kísérleti meghatározásának eredményei dinamikus módszerrel .......................... 67

5.1.2.1. VMD elrendezés eredményei és a hiszterézis megállapítása .................................... 67

5.1.2.2. DCMD elrendezés eredményei és a hiszterézis megállapítása ................................. 69

5.1.3. $\quad \mathrm{LEP}_{\mathrm{w}}$ mérési módszerek összehasonlítása ....................................................... 72

5.1.4. Nedvesedett membránok regenerálásának eredményei ........................................... 72 
5.1.4.1. Regenerálás magas hőmérsékleten.............................................................. 72

5.1.4.2. Regenerálás vákuum segítségével............................................................... 73

5.2. Olaj-víz emulzió szétválasztása vákuum-membrándesztilláció segítségével .......................... 74

5.2.1. LEP érték változásának vizsgálata a model $\mathrm{O} / \mathrm{V}$ emulzió összetételének függvényében,

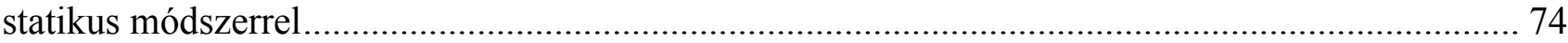

5.2.2. LEP érték változásának vizsgálata a model $\mathrm{O} / \mathrm{V}$ oldat összetételének függvényében,

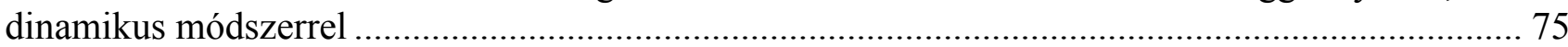

5.2.3. $\mathrm{O} / \mathrm{V}$ emulzió szétválasztásának eredményei vákuum-membrándesztillációs berendezéssel..

5.3. A többlépcsős membrános eljárás zsályahatóanyagok kinyerésének eredményei..................... 82

5.3.1. Zsályakivonat mikroszürésének eredményei ........................................................... 82

5.3.2. Zsályakivonat fordított ozmózisos elősürítésének eredményei ...................................8 83

5.3.3. Zsályakivonat végsürítése ozmotikus desztillációval ............................................... 85

5.3.4. Zsályakivonat bioaktív komponseinek vizsgálata...................................................... 86

5.3.4.1. Zsályakivonat összes polifenol, összes flavonoid és antioxidáns kapacitásának vizsgálata

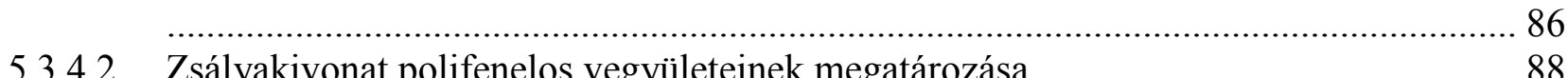

5.4. Új ozmotikus oldatok lehetőségének vizsgálata ........................................................... 91

5.4.1. Különböző ozmotikus oldatok hatékonyságának összehasonlítása ............................... 91

5.4.2. Kísérletterv kiértékelése a kiválasztott ozmotikus oldat müveleti paramétereire.............. 92

5.5. Meggysürítmény kíméletes sürítése kapcsolt membrános eljárással ...................................96

5.5.1. Meggylé elöszürése és hideg csírátlanítása mikroszüréssel.........................................96

5.5.2. Meggylé elösürítése fordított ozmózissal spirál tekercs modullal ............................... 101

5.5.3. Meggylé elősürítése fordított ozmózissal, lapmembrán modullal ................................ 102

5.5.4. Meggylé koncentrálása ozmotikus desztillációval..................................................... 104

5.5.5. Meggylé analitikai vizsgálata............................................................................... 108

5.6. Új tudományos eredmények.................................................................................. 113

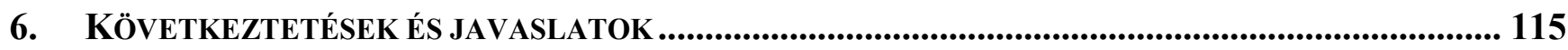

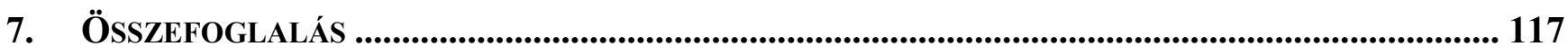

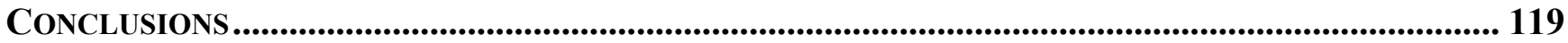

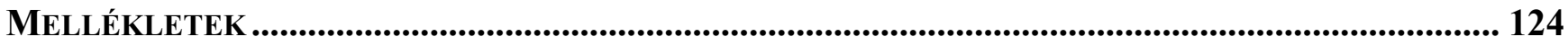




\section{JELÖLÉSEK, RÖVIDÍTÉSEK JEGYZÉKE}

$J_{i} \quad$ i-edik komponens komponensáram sürüsége (fluxus), $\quad \mathrm{kgm}^{-2} \mathrm{~s}^{-1}$

$k_{f} \quad$ betáplált elegy membrán desztillációs anyagátadási együtthatója, $\quad s m^{-1}$

$k_{p} \quad$ permeátum membrán desztillációs anyagátadási együtthatója, $\quad s m^{-1}$

K membrán desztilláció anyagátbocsátási tényező, $s m^{-1}$

$k_{m} \quad$ membrán permeabilitási együtthatója $\quad s m^{-1}$

$P_{i} \quad$ i-edik komponens gőznyomása $\quad P a$

$T_{i} \quad$ i-edik komponens hömérséklete $\quad{ }^{\circ} \mathrm{C}$

$\delta \quad$ határréteg vastagsága, $\quad m$

$\delta_{m} \quad$ membrán vastagsága, $m$

$d_{p} \quad$ pórusok átlagos átméröje, $\quad m$

f csősurlódási tényező,

$L_{e} \quad$ egyenértékủ csőhossz, $\quad m$

$\gamma_{L} \quad$ felületi feszültség, $\quad \mathrm{Nm}^{-2}$

$\theta \quad$ peremszög,

A membrán hasznos felülete, $\quad m^{2}$

$\Delta m \quad$ tömegváltozás, $\quad \mathrm{kg}$

$\Delta t \quad$ mérési időintervallum, $s$

VRF sürítési arány,

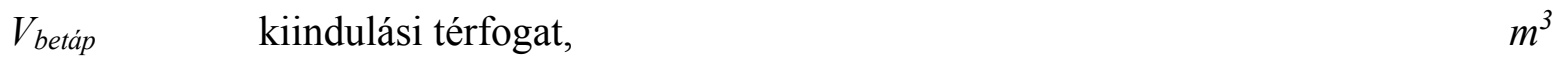

$V_{\text {Ret }} \quad$ retentátum térfogata, $\quad m^{3}$ 
$v$

$\eta$

$r_{p}$

$L$

$\varrho$

$\lambda_{v}^{\prime}$

$c$

LEP

B

$R_{M}$

$R_{P}$

$R_{F}$

$D C M D$

LGMD „liquid gap membrane distillation”

VMD „vacuum membrane distillation”

AGMD ,air gap membrane distillation”

SGMD „Sweeping gap membrane distillation”

TSGMD „thermal sweeping gas membrane distillation” $m s^{-1}$

Pas

$m$

$m$

$\mathrm{kgm}^{-3}$

$W m^{-1} K^{-1}$

moldm-3

$P a$

$\mathrm{m}^{-1}$

$\mathrm{m}^{-1}$

$\mathrm{m}^{-1}$ 


\section{BeVEZETÉS}

A mai ember pazarló habitusával nemcsak saját jövőjét, hanem az egész földi bioszféra fennmaradását veszélyezteti, vagy legalábbis jelentős hatást gyakorol rá. Mint ahogyan az élő szervezetek alapvető eleme a víz, így a bioszféra számára is elengedhetlen annak megfelelö állapota, hozzáférhető optimális mennyisége. Az ember által a történelem során feltárt fizikai jelenségeken alapuló ipari folyamatok megváltoztatták a bioszférában jelenlevő víztömeg tulajdnoságait, ezzel közvetlen hatást gyakorolva az összes élőlényre. Így beláthatjuk, hogy az egyik legfontosabb - hanem a legfontosabb - feladatunk, kihívásunk olyan eljárások kidolgozása, azaz olyan termodinamikai utak feltárása, melyekkel nem tovább távolodunk, hanem inkább újra közelítünk az alapvetően holisztikus létezés „fenntarthatósága” felé. Úgy hiszem, hogy a membrándesztilláció technológiája jelentős részt vehet ki ennek a küldetésnek a beteljesítéséből.

Habár a membrándesztilláció alapvető elveit már az 1960-as évek elején szabadalmaztatták (BODELL 1963, FINDLEY 1967), az 1980-as évek közepéig alig találunk olyan szakirodalmi forrásokat, amelyek ennek a müveletnek a mélyebb vizsgálatával, vagy fejlesztésével foglalkoznának. Az 1980-as évek közepére új területek nyíltak meg a membrános eljárások fejlesztésében, így a membrándesztilláció kutatása is új erőre kapott. Ettől az időszaktól kezdődően világszerte egyre több kutatócsoport fordította figyelmét a membrándesztilláció alap- illetve alkalmazási területeinek kutatására, és ez a tendencia azóta is töretlen (KHAYET 2011b) (1. ábra).

A membrándesztilláció egy olyan müvelet, amely homogén folyadékelegyek és oldatok komponenseinek szétválasztására alkalmas. A membrándesztilláció, mint elnevezés a hagyományos desztillációs eljárásból ered: mindkét esetben a szétválasztás alapja a gőz-folyadék rendszerek egyensúlyi feltételei, és mindkét müvelet hőenergiát igényel a megvalósításhoz. A fő különbség közöttük az, hogy amíg a hagyományos desztillácós és bepárlásos eljárások esetében a szétválasztani kívánt elegy hőmérsékletét annak forráspontjáig kell emelni - melyet külső energia bevitelével, leggyakrabban gőzzel való fütéssel érhetünk el, mely jelentős fosszilis energiát igényelhet-, addig a membrándesztilláció esetében a membrán jelenléte miatt a forrásig nem kell eljutnunk. 


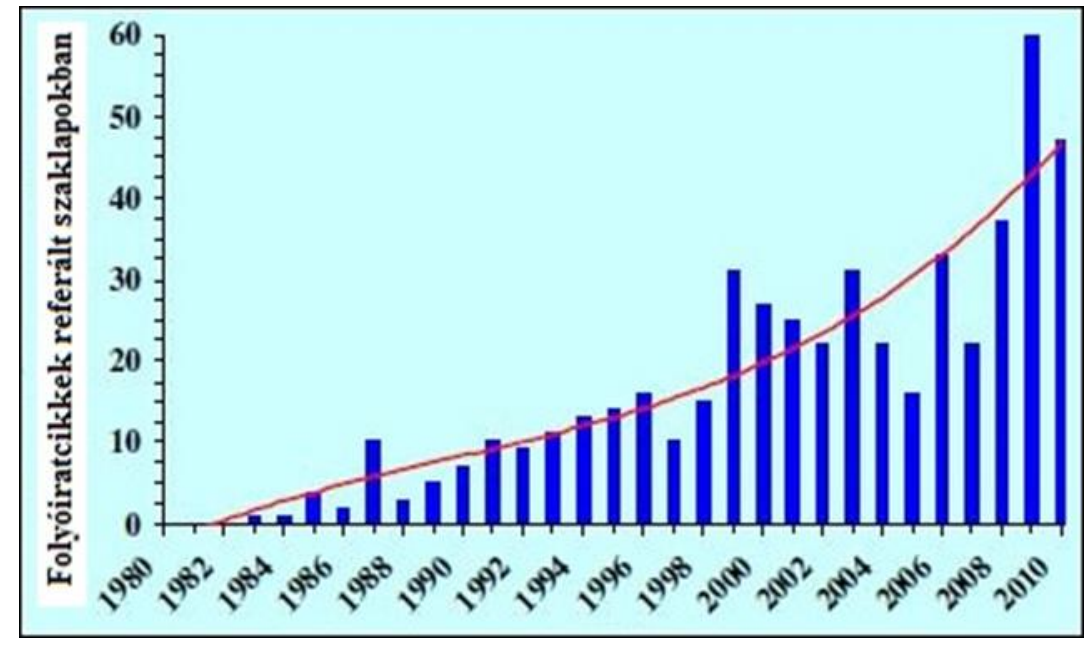

1. ábra A membrándesztillációs folyóiratcikkek számának rohamos növekedése (KHAYET és MATSUURA 2011b)

Habár intenzív párolgás történik a membrán modulban, mégis a szétválasztást elviekben akár szobahőmérsékleten is el tudjuk végezni. Így, ha az elegy $40-60^{\circ} \mathrm{C}$-on áll rendelkezésre, ez a hőtartalom már elegendő lehet a membrándesztilláció müveletének végrehajtásához, ezáltal a külső energiaszükséglet jelentősen lecsökken. Ebből kifolyólag a membrándesztilláció alapvető előnye a hagyomány termikus eljárásokkal szemben az, hogy az ún. technológiai hulladékhők is alkalmasak a folyamat megvalósítására, mint például ipari motorok és kompresszorok, generátorok müködése során felszabaduló súrlódásos hőveszteség, vagy a hulladékégetők füstgázának hőtartalma. Ezeket a „felesleges hőket” eddig gyakran a környezet felé vezették el, illetve egyéb, az adott termelés szempontjából kevésbé értékes célokra használtak fel. A membrándesztilláció alkalmazásával gazdaságosabb és környezetvédelmi szempontból is elönyösebb rendszerek valósíthatóak meg. Ezen felül, a hagyományos müveletekhez képest alacsonyabb üzemletési hőmérséklet miatt kiváló alternatívát nyújt különböző élelmiszeripari alkalmazások megvalósítására, ahol az oldat, vagy elegy értékes komponensei gyakran hőre érzékeny alkotók.

Az ozmotikus desztilláció gyakorlatilag a membrándesztilláció egyik formája, izotermikus membrándesztillációnak is szokták nevezni, ezáltal szintén homogén folyadékelegyek és oldatok komponenseinek szétválasztására alkalmas. Ebben az esetben az anyagtranszporthoz a kívánt hajtóerő nem közvetlenül hőmérsékletkülönbségen alapul, hanem, egy az átadott komponensre vonatkozatott alacsony kémiai aktivitású ozmotikus ágens segítségével áll elő - az anyagtranszport egészen addig tart, amíg ennek az ágensnek az átadott komponensre vonatkoztatott kémiai aktivitása a kezelni kívánt elegy aktivitásától alacsonyabb. A szétválasztást alapvetően itt is a gőz-folyadék egyensúly szabja meg. Ez a 
művelet különösen nagy lehetőségeket rejthet magában élelmiszeripari alkalmazások tekintetében az említett hőérzékeny komponensek megóvása miatt. Gyümölcslevek, gyógyszer hatóanyagok sürítésére például egy kiváló lehetőségnek mutatkozik, mivel nem igényel kívülröl befektetendő hőt, $25-30^{\circ} \mathrm{C}$-on is elvégezhetö.

A membrán- és ozmotikus desztilláció folyamatának ipari léptékü megvalósítására jelenleg még csak elvétve találunk példákat, leginkább a tengervíz sótalanítására kialakított membrándesztillációs rendszereket lehet már megvásárolni, melyeket gyakran napenergia és/vagy kapcsoltan technológiai hulladékhő hajt. Az alacsony fajlagos produktivitás miatt szükséges nagy membránfelület, a termékek a kiindulási eleggyel bizonyos körülmények mellett történő szennyeződése (membránpórusok nedvesedése), a léptéknöveléshez szükséges megfelelö modulkialakítások meglétének hiánya még korlátozzák a nagyipari méretü megvalósítást. Az ozmotikus desztilláció alkalmazását leginkább a kimerült ozmotikus ágens gazdaságos regenerálása korlátozza.

Dolgozatomban bemutatom ennek a két müveletnek a legjellemzőbb tulajdonságait, egy átfogó irodalmi áttekintéssel azokat a mérnöki megfontolásokat, melyek segíthetnek e müveletek müködésének mélyebb megértésében, így a további fejlesztési utak feltárásában. Majd dolgozatom első téziseként a membrán- és ozmotikus desztillációs müveletek során előállított termékek minősége szempontjából kiemelten fontos paraméter, az ún. folyadék behatolási nyomás (Liquid Entry Pressure LEP) mérésének egy új, dinamikus módszerét mutatom be, összehasonlítva az irodalomban fellelhető statikus módszer eredményeivel. Ehhez kapcsolódóan a nedvesedett membránpórusok vákuumos regenerálásának új lehetőségét is bemutatom. Második tézisként zsályakivonat és meggylé kíméletes besürítsését végeztem kapcsolt membrános eljárással, nyomon követve a termékek összantioxidáns kapacitását, összflavonoid és összpolifenol tartalmát, mint minőségi jellemzőket. Harmadik és negyedik tézisként az ozmotikus desztilláció produktivitásának céljából új, eddig kevéssé vizsgált ozmotikus ágenseket alkalmaztam, melyeket az élelmiszeripar, vagy mezőgazdaság opcionálisan értékesíthet. A leghatékonyabbakkal konkrét besürítési feladatokat valósítottam meg meggylé sürítésére, miközben vizsgáltam antioxidáns kapacitásának, polifenoltartalmának változását. 
IRODALMI ÁTTEKINTÉS

\section{IRODALMI ÁTTEKINTÉS}

\subsection{A membrán- és ozmotikus desztilláció alapjai}

A membrándesztilláció egy jellemző példája az ún. membránkontaktorok családjának. A membránkontaktor olyan jellegü alkalmazás, ahol a membrán nem a „hagyományos”, szürési elven szabja meg a szétválasztást (mint például a nyomás által vezérelt membránszürések esetében), hanem sokkal inkább, mint egy kapocs, kapcsolatot létesít, elősegíti a hatékony érintkeztetést két elegyedö, vagy nem elegyedő fázis között. Így a membránkontaktorok alkalmazásakor a membránon való áthaladás más jelenségek alapján zajlik le, szemben az említett membránszürésekkel. Ilyen eljárások például a membrános abszorpció/sztrippelés, membránextrakció, membrános kristályosítás, membrános emulzifikálás, valamint a membrándesztilláció is.

A membrándesztilláció egy olyan szétválasztási müvelet, mely homogén folyadékelegyek és oldatok komponenseinek szétválasztására alkalmas. Kombinálja a membrántechnológiát és a hagyományos desztillációt, a szétválasztás termodinamikai alapja a szétválasztandó elegy gőz-folyadék egyensúlya. A folyamat során hő- és anyagátviteli jelenségek együttesen zajlanak le (CSÉFALVAY 2011). A membrándesztillációs membránnal szemben támasztott alapvető követelmények a membrán pórusossága és hidrofobicitása. E két jellemző kulcsfontosságú, mivel a legtöbb ipari folyadék vizes közeget jelent. Ezáltal az elegy, vagy oldat nem képes nedvesíteni a hidrofób membrán pórusait, azok belsejébe nem tud behatolni, ezért a pórusok bejáratainál gőz-folyadék határfelületek jönnek létre. A pórusokban levegö, valamint az illékony komponensek gőzállapotú molekulái találhatóak (2. ábra).

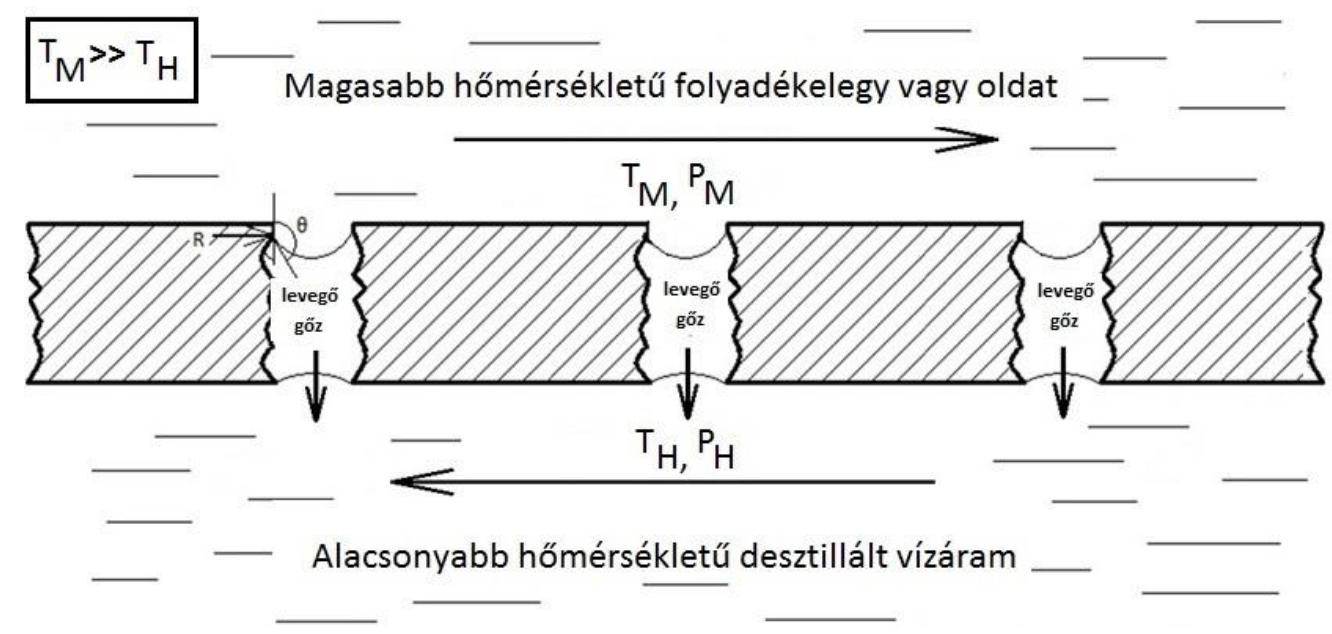

2. ábra A membrándesztilláció egyik jellemző megvalósítási módja

(IMDAKM és MATSUURA 2005) 
Ha a membrán két oldalán található közegek gőznyomása eltérő, a magasabb gőznyomású gőz-folyadék határfelületről az alacsonyabb gőznyomású határfelület felé gőz fázisú, illékonykomponens-áram indul a membrán pórusain át, azaz az illékonyabb komponens „átpárolog”. Így, a szétválasztás hatékonyságát alapvetően mindig az adott körülményekre vonatkozó gőz-folyadék egyensúlyok szabják meg, amely egyensúlyok a hőmérséklet, az összetétel és a nyomás függvényei.

A membrándesztilláció jellemző alkalmazásai az oldatok koncentrációjának növelése, azaz a sủrítés, valamint tiszta víz, desztillált víz előállítása tengervízböl, vagy különböző szennyvizekböl. A leginkább nem illékony komponenseket tartalmazó vizes oldatok esetében (ilyen például a tengervíz) gyakorlatilag csak az oldószer, azaz a vízmolekulák párolognak át a membrán pórusain, amely folyamat a kiindulási oldatot nagyobb koncentrációjú állapotba juttatja, míg a másik oldalon desztillált víz jelentkezik, mint termék. Természetesen többféle illékony komponens jelenléte esetén (pl. alkoholok fermentlevekben, vegyipari szennyvízek, stb.) a többkomponensű gőz-folyadék rendszereknél megismert elvek alapján zajlik le a szétválasztás, azaz a jelen lévő komponensek gőztenziójának viszonyai fogják meghatározni a szétválasztás hatékonyságát.

A membrándesztilláció műveletének tanulmányozása során a kutatók és fejlesztők többféle megvalósítási módokat, ún. konfigurációkat alakítottak ki. A 3. ábra szemlélteti az alapvető membrándesztillációs konfigurációkat. A membrándesztilláció művelete gyakorlatilag a következő részjelenségekből tevődik össze, és a különböző konfigurációk csak a membránon áthaladt komponensek kondenzációjának megvalósításában térnek el egymástól:

- az illékony komponens(ek) elpárolgása a betáplálás oldalon, a pórusok bejáratánál létrejövő gőz-folyadék határfelületekröl,

- az elpárolgott, gőz fázisban lévő illékony komponens(ek) molekuláinak a membrán pórusain diffúzióval való áthaladása,

- a gőzmolekulák kondenzációja:

- DCMC ("direct contact membrane distillation") esetében a membrán másik oldalán áramló hideg folyadékáramba történik a kondenzáció (3. a.),

- LGMD ("liquid gap membrane distillation"), ahol egy hütött felületen mentén felhalmozódó desztillátumba történik a kondenzáció. E felületet egy, annak másik oldalán áramló hideg folyadékárammal tartjuk alacsony hőmérsékleten (3. b.), 
○ VMD ("vacuum membrane distillation”) esetében a vákuumenergia által elpárologtatott gőzmolekulák a membránmodulon kívül, egy hűtőcsapdában kondenzálnak (3. c),

○ SGMD ("sweeping gas membrane distillation”) esetében egy inert gázáram távolítja el a gőzmolekulákat a pórusokból és viszi a membrán modulon kívülre, ahol azok a VMDhez hasonlóan kondenzálnak (3. d.),

○ TSGMD ("thermostatic sweeping gas membrane distillation”) esetén a SGMD-hez hasonlóan, egy inert gázáram viszi el a molekulákat, miközben ennek hütését még a membrán modulba beépített, folyamatosan hütött felülettel biztosítják (3. e.),

○ AGMD (“air gap membrane distillation”) esetében egy, a membrán túloldalától meghatározott távolságra lévő (általában 1-5 mm) hütött felület mentén történik a kondenzáció (3. f.).

Mindegyik konfigurációnak vannak előnyei és hátrányai is egyaránt. Említésképpen, a DCMD konfiguráció viszonylag egyszerü kivitelezésének elönyét az ebben a konfigurációban fellépő legnagyobb arányú, a membrán anyagán történő vezetéses hőveszteség korlátozza. Ez a hőveszteségi jelenség az AGDM esetén jelentősen lecsökken, mivel ebben az esetben egy mozdulatlan, kis vastagságú légréteg van jelen a desztillátum oldalán, ami növelni a hőellenállást, így csökkenti a vezetéses hőveszteséget. A VMD szintén hatékonynak bizonyul a hőveszteség minimalizálása szempontjából a kisebb, explicit hőmérsékletkülönbség miatt, viszont a vákuum által létrehozott magasabb transzmembrán hidrosztatikai nyomáskülönbség növeli a pórusok nedvesedésének, elárasztásának kockázatát. Ezek alapján beláthatjuk, hogy minden egyes feladat esetén külön mérlegelnünk kell, mely előnyök illetve hátrányok hangsúlyosabbak, hogyan tudnánk hatékonyabb szétválasztást elérni gazdaságosan.

Itt meg kell említenem a membrándesztilláció egy speciális esetét, az ozmotikus desztillációt, amely gyakorlatilag a DCMD konfiguráció egyik megvalósítási formája. Ebben az esetben a két fázis között nincs hömérséklet-különbség (pontosabban, nem feltétlen van), viszont a betáplálás és az ozmotikus ágens közötti kémiai potenciálkülönbség biztosítja a hajtóerőt a betáplált elegy szétválasztásához. Ez az ozmotikus ágens általában egy telített sóoldat (leggyakrabban $\mathrm{CaCl}_{2}$ oldat), mely biztosítja a kívánt alacsony gőznyomást a szétvalasztani kívánt, betáplált fázissal szemben. 


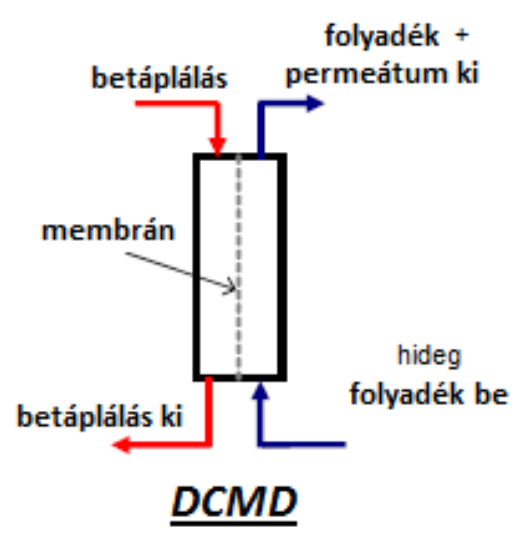

(a)

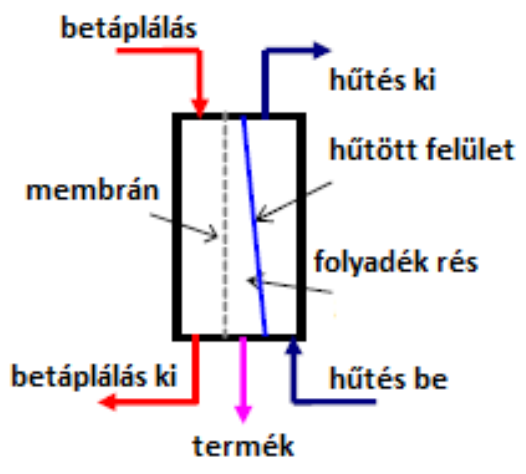

$\underline{L G M D}$

(b)

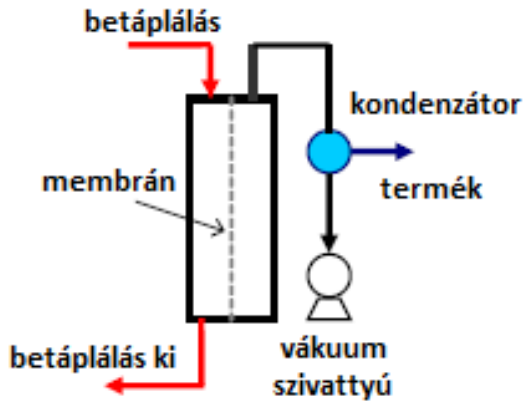

$\underline{V M D}$

(c)

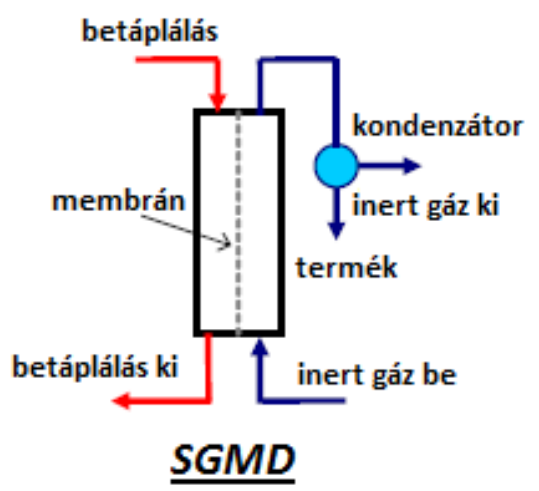

(d)

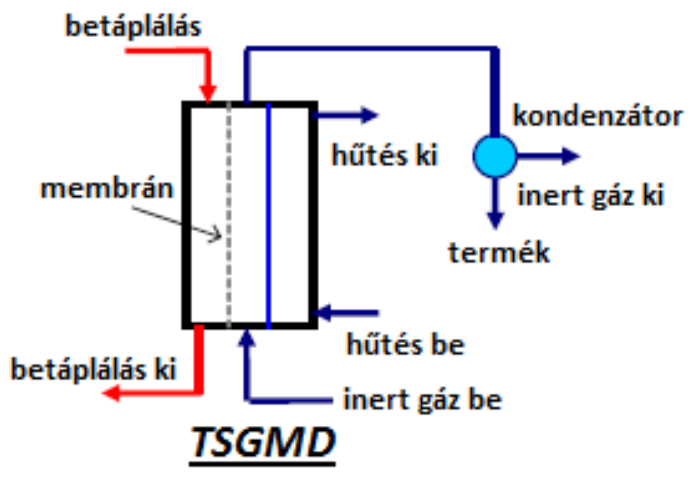

(e)

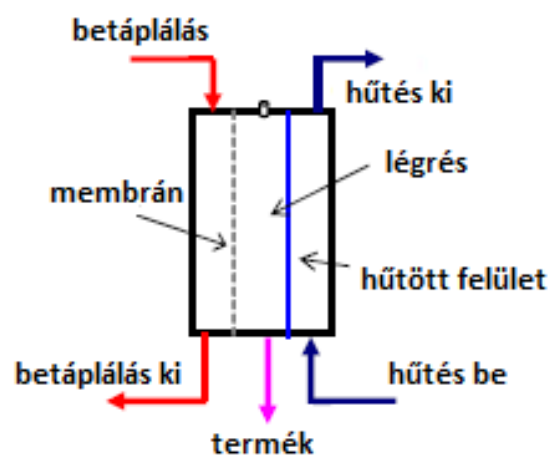

AGMD

(f)

3. ábra Membrándesztillációs konfigurációk: a.) DCMD, b.) LGMD c.) VMD d.) SGMD, e.) TSGMD, f.) AGMD (KHAYET és MATSUURA, 2011b)

Mint már azt említettem, az összes konfigurációban közös az, hogy hidrofób, porózus membránt alkalmaz. A gyakorlat szerint a megfelelö pórusméret-tartomány 0,01-1 $\mu \mathrm{m}$, mely 
tartományban kellő produktivitás érhető el a pórusok nedvesedésének csekély lehetőségével. A leggyakrabban alkalmazott membránok polimerekből készülnek, polipropilénből (PP), polivinilidénfluoridból (PVDF), politetrafluoretilénből (PTFE) valamint polietilénböl (PE). Ezeknek az anyagoknak vizes oldatokkal való nedvesítése során a nedvesítési peremszög nagy (hozzávetőlegesen 130), így a pórusok spontán nedvesedésének esélye viszonylag alacsony. A kereskedelemben hozzáférhető, hidrofób polimer mikroszürő membránok általában alkalmasak ezeknek az igényeknek a kielégitésére, a fellelhető membrándesztillációs publikációk jelentős része ezeknek a membránoknak az alkalmazásán alapul, de egyre többen foglalkoznak kifejezetten membrándesztillációs célokra előállított membránok fejlesztésével, vagy a meglévő hidrofób, vagy esetleg hidrofil membránok felületének módosításával. A modulelrendezést illetően szinte az összes klasszikus membránmodult vizsgálták; találunk példát lapmembránok, csőmembránok, kapillárcsöves, vagy akár spirál tekercs modulokkal elvégzett kutatásokra is. Különböző speciális kialakítású modulokat és berendezéseket is fejlesztenek, melyek közül a szabadalmaztatott eljárások közül egy-kettő már a kereskedelemben is kapható.

SUSANTO (2011) szerint más szétválasztási műveletekkel szemben a következő előnyei lehetnek a membrándesztillációnak:

- alacsony hőmérsékleten el lehet végezni, így az olyan energiaforrások, mint a napenergia, napkollektorok használata, geotermikus energia, különböző ipari folyamatokból származó hulladékhök hatékonyan felhasználhatóak (habár ez nem jelenti azt, hogy a folyamat fajlagos energia szükséglete alacsony lenne, mivel a párolgási hőt mindenféleképpen be kell fektetni!),

- kisebb helyet foglal, mint egy hagyományos desztillációs berendezés,

- magas végső oldottanyag-koncentráció érhető el,

- müködik magas koncentrációjú betáplálás mellett, akár közel telített oldatokkal is,

- jelentősen kisebb transzemembrán hidrosztatikus nyomáskülönbség szükséges, szemben a nyomás által vezérelt membránszürési eljárásokkal (fordított ozmózis akár $>50$ bar)

- kevésbé érzékeny a betáplálás fizikai és kémiai jellemzöire ( $\mathrm{pH}$, összes oldott anyag, stb.), kevesebb előkezelés szükséges, mint a nyomás által vezérelt membránszürési eljárások esetében.

Sajnos ezek mellett az elönyök mellett jelenleg több tényező is megakadályozza a membrándesztilláció ipari alkalmazását. Ilyenek például az alacsony desztillátumfluxus, a müvelet 
leírásának komplexitása, valamint az, hogy jelenleg a kereskedelemben nem hozzáférhető kifejezetten membrándesztillációs célokra fejlesztett membrán, membráncsoport. Ezek a korlátok elegendőek ahhoz, hogy az iparban még alig terjedt el ez a müvelet.

\subsection{A membrán- és ozmotikus desztilláció modellezése}

Ebben a fejezetben azokat az alapvető müszaki fogalmakat foglalom össze, melyek bemutatása elengedhetetlenül szükséges a membrán-és ozmotikus desztilláció műveletének megértéséhez, tanulmányozásához.

\subsubsection{A membrán- és ozmotikus desztilláció anyagátbocsátása}

Az 4. ábra szemlélteti a membrán-és ozmotikus desztillációs anyagátbocsátás folyamatát.
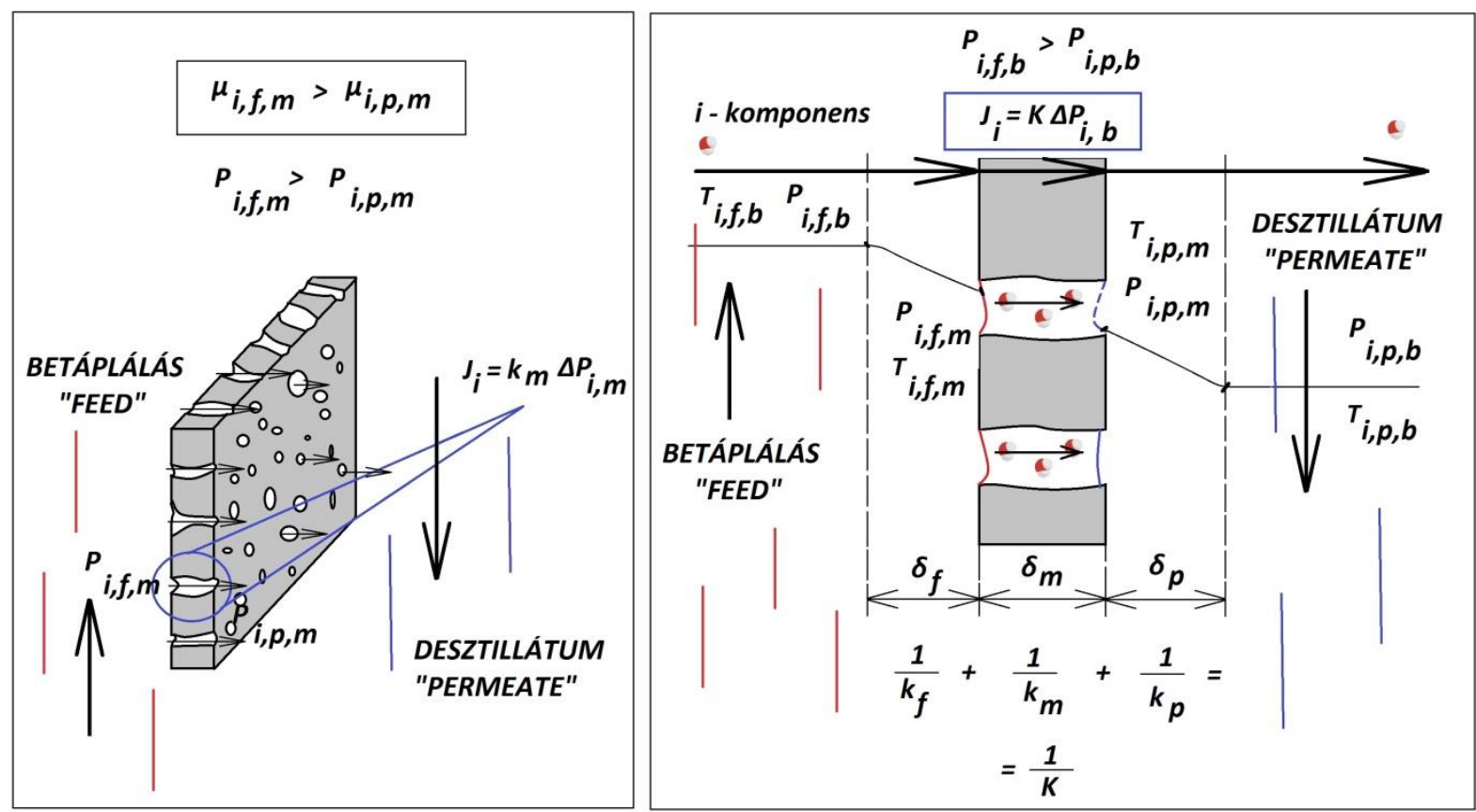

4. ábra Anyagátbocsátás membrán- és ozmotikus desztilláció (EL AMALI et al. 2004)

A membrándesztilláció fluxusának általános képlete a membrán pórusainak bejáratánál kialakuló gőz-folyadék fázishatárok parciális gőznyomáskülönbsége alapján:

$$
J_{i}=k_{m} \Delta p_{i, m}
$$

ahol $\Delta p_{i, m}$ jelenti az i-edik komponens parciális gőznyomáskülönbségét a gőz-folyadék fázishatárokon, a membrán felülete mentén, $J_{i}$ pedig a folyamat komponensáram-sürüsége, azaz a desztillátum fluxusa. 
A (1) összefüggés megadja a membrán- és ozmotikus desztilláció fluxusát a membrán permeabilitás és a membrán felületén jelen lévő gőznyomások ismeretében. A valóságban azonban a membrán felületén levő gőznyomások értékeit nem tudjuk megmérni, sokkal inkább a fötömegbeli összetételről és hőmérsékletről tudunk információt szerezni hőmérsékletméréssel, vízgőznyomás méréssel, számítással.

Felhasználva a Lewis-Whitman féle kétfilm elméletet (1923), az anyagátbocsátás folyamatát stacionárius állapotban felírhatjuk a részfolyamatok figyelembe vételével is (2):

$$
J_{i}=k_{f}\left(p_{i, f, b}-p_{i, f, m}\right)=k_{m} \Delta p_{i, m}=k_{p}\left(p_{i, p, m}-p_{i, p, b}\right)=K \Delta p_{i, b}
$$

Tehát a membrándesztilláció fluxusa a következő részfolyamatokból tevődik össze:

- anyagátadás a betáplálás oldal főtömegétől az anyagátadási határrétegen keresztül $\left(\delta_{f}\right)$ a membrán pórusok bejáratánál kialakult gőz-folyadék határfelületig $\left(P_{i, f, b}-P_{i, f, m}\right)$,

- az elpárolgott illékony komponensek diffúziója gőz formában a membrán pórusain keresztül $\left(P_{i, f, m}-P_{i, p, m}\right)$,

- az átadott komponensek kondenzációja után azok anyagátadása a desztillátum oldali gőz-folyadék határfelületről a desztillátum oldal fötömegéig az anyagátadási határrétegen $(c)$ keresztül $\left(P_{i, p, m}-P_{i, p, b}\right)$.

ahol $\Delta p_{i, b}$ a fötömegbeli gőznyomáskülönbség, $K$ a membrán desztillációs együttható, amely magában foglalja a betáplálás oldali anyagátadási tényezőt $\left(k_{f}\right)$, a membrán permeabilitási tényezőt $\left(k_{m}\right)$ és a permeátum oldali anyagátadási tényezőt $\left(k_{p}\right)$. $K$ értékének reciproka jelenti az anyagátbocsátás összes ellenállását, ami a részfolyamatok ellenállásának az összege (3) (CHIAM és SARBATLY 2013):

$$
\frac{1}{K}=\frac{1}{k_{f}}+\frac{1}{k_{m}}+\frac{1}{k_{p}}
$$

A membrán- és ozmotikus desztilláció leírására általánosságban két fő szempont szerint osztályozhatjuk a müveletre ható paramétereket, melyek a hajtóerőt, a fázisok anyagátadási tényezőit, valamint a membrán permeabilitását befolyásolják.

A membránra jellemző paraméterek:

- membrán anyaga, felületének fizikai-kémiai viselkedése a betáplált oldattal szemben (membrán felületi energiája, betáplálás felületi feszültsége $(\gamma)$, peremszög $(\theta)$ ), 
- membrán vastagsága $\left(\delta_{m}\right)$,

- membrán pórusok átlagos átmérője $\left(d_{p}\right)$,

- membrán pórusátmérő eloszlása,

- membrán porozitás $(\varepsilon)$,

- membránpórus kanyargóssága (tortuozitás) $(\tau)$,

- folyadék behatolási nyomás (LEP).

A müveleti paraméterek és a betáplálás állapota:

- betáplálás hőmérséklete $\left(T_{f}\right)$,

- betáplálás összetétele $\left(X_{i}\right)$,

- betáplálás fizikai jellemzői (sürüség, viszkozitás, diffúziós állandók, stb.),

- betáplálás áramlási sebessége, vagy keverési sebessége (eljárás függvénye) $\left(v_{f}\right)$,

- áramlási csatorna geometriája,

- a membrán két oldala közti gőznyomáskülönbség, azaz a hajtóerö $\left(\Delta p_{m}\right)$,

Természetesen, a különböző membrándesztillációs konfigurációknál további műveleti paramétereket kell számításba vennünk (pl.: DCMD-nél a desztillátum oldali áramlási sebesség, áramlási körülmények, AGMD esetében a mozdulatlan légréteg vastagsága, SGMD esetében az inert gázáram áramlási sebessége, hőmérséklete, stb). Ezeken kívül léteznek még a folyamat hatékonyságát korlátozó egyéb jelenségek is, mint például a hőmérséklet és koncentráció polarizáció, a pórusok eltömődése, lerakódások a membrán felületén, vagy akár a membrán tömörödöttségének mértéke, (GRYTA et al. 2008a; GRYTA et al. 2008b; LAWSON et al. 1995; NGHIEM és CATH 2011).

\subsubsection{Múveleti paraméterek hatása}

Az előzőekben bemutatott összefüggések, és az irodalomban fellelhető vizsgálati eredmények alapján a következő alfejezetekben röviden összefoglalom, hogyan hatnak a müveleti paraméterek a membrándesztilláció hatékonyságára.

\subsubsection{Betáplálás hőmérsékletének és a hőmérséklet-különbségnek a hatása}

A betáplálás hőmérsékletének hatása a desztillátum fluxusára széles körben vizsgált paraméter, leginkább a $20-80^{\circ} \mathrm{C}$ hőmérséklet-tartományban való vizsgálatról vannak eredmények. Általánosságban megállapítható, hogy a desztillátumfluxus exponenciálisan növekszik a betáplálás hőmérsékletének 
emelésével, mely jelenség a gőznyomás exponenciális hőmérsékletfüggésének köszönhető (KHAYET és MATSUURA, 2011a; LAWSON 1997). A membrándesztilláció hajtóereje a membrán két oldala közt fennálló gőznyomáskülönbség, amit a két oldal hőmérsékletkülönbségével állítunk elő DCMD, AGMD, SGMD esetében és az eltérő koncentrációkkal ozmotikus desztilláció esetén. Lineáris kapcsolat van a hőmérsékletkülönbség és a desztillátumfluxus között (LAWSON 1997; SCHOFIELD et al. 1987; SANJAY NENE et al. 2002; KIM et al. 2004).

\subsubsection{Betáplálás összetételének hatása}

Ha a betáplálás nem illékony komponenseket tartalmaz, mint például oldott sókat, azok jelenléte csökkenti a parciális vízgőznyomást, ezáltal a membrándesztilláció folyamatának hajtóerejét. Emellett a koncentrációpolarizáció jelensége is csökkenti a transzmembrán desztillátumfluxust, mivel így a membrán felületén magasabb a koncentráció, mint a fötömegben az elpárolgás miatt (4. ábra). Habár ennek a polarizációnak a szerepe minimális a hőmérsékletpolarizáció hatékonyságcsökkentő hatásával összehasonlítva (4. ábra) (KHAYET et al. 2004; MARTINEZ-DIEZ et al. 1998; MARTÍINEZ-DÍEZ et al. 1999; SCHOFIELD et al. 1990a).

Abban az esetben, ha a betáplálás illékony szerves alkotókat tartalmaz (mint például alkoholok), a megnövekedő koncentráció hatása teljesen eltérö lehet az előbb leírtaktól, a jelen levő szerves komponens termodinamikai jellemzőitől és a vízhez való viszonyától függ, hogyan történik a szétválasztás. Általában a megnövekedett illékony szerves komponens koncentráció a desztillátumfluxus növekedéséhez vezet, mivel az illékony szerves komponens növeli a parciális gőznyomás értékét. Ilyen esetekben különös tekintettel kell lenni a membrán nedvesedésének lehetősége iránt.

Amit érdemes még itt megemlíteni, hogy abban az esetben, amikor az oldat az illékony szerves komponens mellett valamilyen nem illékony alkotót is tartalmaz (sók), a termodinamikai tulajdonságok szintén megváltoznak, és hatással lehetnek mind a folyamat hatékonyságára, mind a szelektivitására (Banat 1999; Lee 2001). Továbbá, abban az esetben, ha a betáplálás illékony szerves komponenst tartalmaz, a hőmérséklet növelése a szétválasztás hatékonyságának csökkenését eredményezheti, ez számos publikációban bemutatásra került (RIVIER et al. 2002; GARCÍA-PAYO et al. 2002; BANAT 1999; BANDINI és SARTI 1997; HASANOĞLU et al. 2012; TOMASZEWSKA és MORAWSKI 1998; DRIOLI et al. 1987). 


\subsubsection{Betáplálás áramlási sebességének hatása}

A betáplálás áramlási sebességének növelése növeli a höátadási tényező és anyagátadási tényező értékét, valamint csökkenti a hőmérséklet és koncentráció polarizáció hatásának szerepét, ezáltal a desztillátumfluxus növekedéséhez vezet. Ez a hatás telítési görbe jellegü, magasabb áramlási sebességek mellett egy maximális érték felé tart (BANAT 1994; GARCÍA-PAYO et al. 2000; BANAT 1999; ALKLAIBI és LIOR, 2005). Egyes tanulmányok gyakorlatilag lineáris kapcsolatról számolnak be az áramlási sebesség és a desztillátum fluxusa között (MENGUAL et al. 2004; PHATTARANAWIK et al. 2003; LEE et al. 2001). A nagyobb hatékonyság érdekében érdemes turbulens áramlási tartományban müködtetni a berendezést, ami nagyobb áramlási sebességgel érhető el. Így a membrán felületének hőmérséklete közelebb kerül a fötömeg hőmérsékletéhez, növelve a folyamat hatékonyságát (LAWSON et al., 1996; IZQUIERDO-GIL et al. 1999; SAKAI et al. 1988; MARTINEZ-DIEZ et al. 1998; SCHOFIELD et al. 1990b). Abban az esetben, ha illékony komponens van jelen a betáplálásban, az áramlási sebesség közvetlenül hatást gyakorolhat a szétválasztás hatékonyságára is (BANDINI et al. 1992; GARCÍA-PAYO et al. 2000; BANDINI et al. 1997).

Fontos még megemlíteni, hogy a Re-szám és az áramlási sebesség között lineáris kapcsolat van, míg a nyomásesés a membrán modul hossza mentén és az áramlási sebesség között négyzetes függvénykapcsolat áll fenn (4).

$$
\Delta P_{s}=f \frac{L_{e}}{d_{e}} \rho \frac{v^{2}}{2}
$$

ahol $\Delta P_{s}$ a hidraulikus nyomásesés, $f$ a csősurlódási tényező, $L_{e}$ egyenértékü csőhossz, $d_{e}$ az egyenértékủ csőátmérő, $\rho$ a sürüség, $v$ az áramlási sebesség.

Ezáltal a betáplálás térfogatáram értékének megválasztásánál figyelembe kell vennünk a pórusok esetleges nedvesedését; a transzmembrán hidrosztatika nyomásnak kisebb értéknek kell lennie, mint a kritikus folyadékbehatolási nyomás (lásd. 2.2.3. alfejezet) értékének. Ennek figyelembe vétele mellett lehetőség szerint biztosítani kell a turbulens áramlási körülményeket.

\subsubsection{Membránra jellemző paraméterek hatása}

A membránra jellemző paraméterek közül csak a folyadék behatolási nyomás értékét ismertetem, a többi hatásának mélyebb áttekintése a jelenlegi munka szempontjából nem kiemelkedően fontos, így azt mellőzöm. 


\subsubsection{Folyadék behatolási nyomás (Liquid entry pressure (LEP))}

A membránra jellemző paraméterek közül csak a folyadék behatolási nyomás értékét ismertetem, a többi hatásának mélyebb áttekintése a jelenlegi munka szempontjából nem kiemelkedően fontos, így azt mellözöm.

Az LEP értéke az a minimális transzmembrán hidrosztatikai nyomáskülönbség, ami elegendő a folyadék állapotú betáplálásnak ahhoz, hogy az a felületi és kapilláris erők leküzdésével nedvesítse a membránpórusokat, behatoljon a pórusok belsejébe (5. ábra) (KHAYET et al. 2001; KHAYET et al. 2003; KHAYET et al. 2006; LAWSON 1997; GRYTA 1999).

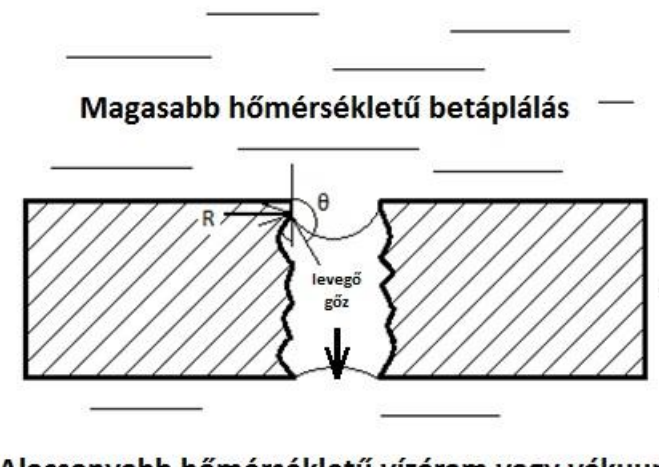

Alacsonyabb hőmérsékletũ vízáram vagy vákuum

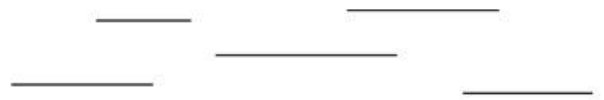

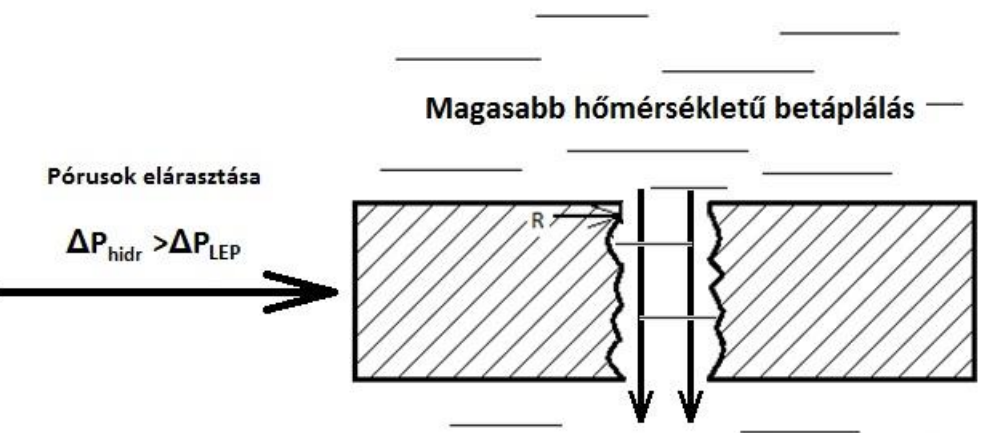

Alacsonyabb hőmérsékletű vízáram vagy vákuum

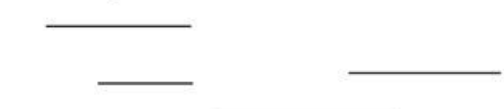

5. ábra LEP - a pórusok nedvesedésének folyamata, DCMD elrendezésben

Mivel ennek a paraméternek a meghatározását vizsgáltam egy új, általam kialakított módszerrel, ennek a paraméternek a definiálására és mélyebb ismertetésére fordítom a következő fejezetet.

Az LEP definíció szerint a Young-Laplace egyenletből vezethető le. Egy membrándesztillációs membrán LEP értékét általában desztillált vízre vonatkoztatva határozzák meg (LEPw) és ez egy jellemző paramétere a membránnak (LAWSON 1997) (5):

$$
L E P_{w}=\frac{-2 B \gamma_{L} \cos \theta}{R_{\max }}
$$

ahol $L E P_{w}$ a desztillált vízre vonatkoztatott folyadék belépési nyomás, $B$ a pórus geometriájára, annak hengerességére utaló tényező ( $B=1$, teljesen hengeres pórust feltételezve), $\gamma_{L}$ a szilárd-folyadék határfelület felületi feszültsége, $\cos \theta$ a peremszög, $R_{\max }$ pedig a legnagyobb pórusok sugara. 
Annak ellenére, hogy a müveleti hőmérséklet és a betáplálás összetétele explicit nem szerepel az összefüggésben, ezek a tényezők hatással vannak a felületi feszültség és peremszög értékére, így közvetve a LEP-t is befolyásolják. A felületi feszültség csökken a hőmérséklet növelésével, tehát magasabb hőmérsékleten nagyobb a pórusok nedvesedésének kockázata. Tiszta víz esetében, a membrán desztillációs müködési hőmérsékleti tartományokon belül ennek hatása gyakorlatilag elhanyagolható; ha a hőmérsékletet $25^{\circ} \mathrm{C}$-ról $50^{\circ} \mathrm{C}$-re emeljük, a felületi feszültség mindössze $5 \%$-ot csökken (6. ábra), így kiválóan megfelel a pórusok elárasztásához szükséges sztenderd körülmények biztosításához. Természetesen ez a hatás a különböző oldatok és emulziók, vagy egyéb diszperz rendszerek esetén kifejezettebb lehet.

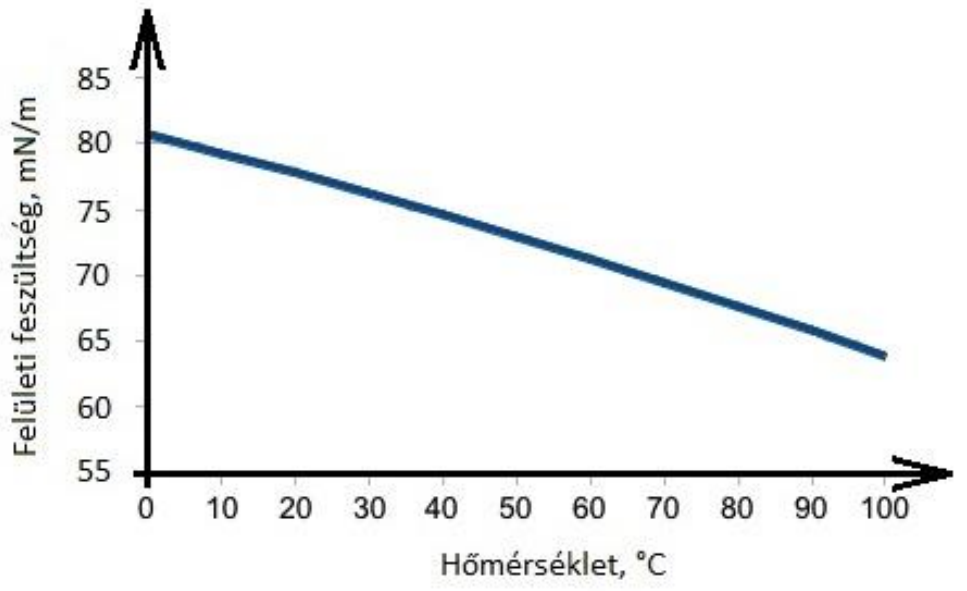

6. ábra Víz felületi feszültségének változása a hőmérséklet függvényében

Általánosságban elmondható, hogy a betáplálási folyadék és a szilárd membránfelület által létrehozott folyadékcsepp peremszögének nagyobbnak kell lennie, mint 90, hogy egy membrándesztillációs feladat megvalósítható legyen az adott membránanyaggal - ettől a peremszögértéktől nevezzünk egy felületet hidrofóbnak. Szuperhidrofób felületeknek és membránoknak nevezzük azokat, ahol ez az érték a $150^{\circ}$-ot is meghaladja (egyes speciális, új membránok esetében ez elérheti a $180^{\circ}$-ot is, de általában a $130^{\circ}$ körüli érték a jellemzö (KHEMAKHEM és AMAR 2011).

Ha abból indulunk ki, hogy tiszta víz - hidrofób membrán által létrejövő peremszög $130^{\circ}$ értéke mellett, közel hengeresnek feltételezett pórusok esetén $(B=1), 1 \mu \mathrm{m}$-es pórusátmérő mellett, akkor az LEP $_{\mathrm{w}}$ értéke mindössze 1,85 bar (LAWSON 1997). A leggyakrabban alkalmazott, kereskedelemben hozzáférhető lapmembránok $\mathrm{LEP}_{\mathrm{w}}$ értéke $0,48-4,63$ barközött található $0,2-1 \mu \mathrm{m}$ átlagos pórusátmérő között. Az M.II. mellékletben megtalálhatóak az irodalomban fellelhető tanulmányokban leggyakrabban alkalmazott membránok LEP ${ }_{\mathrm{w}}$ értékei. MENGUAL és mtsai (2004) vákuum- 
membrándesztilláció során vizsgálták a hő és anyagátadási folyamatokat, és a kísérleteikhez MD 020 CP 2N kapilláris membránt használtak, ami egy nagyon közkedvelt laboratóriumi méretü, mikroszürő membránmodul membrándesztillációs kísérletek elvégzésére. Ennek LEP ${ }_{\mathrm{w}}$ értéke 1,40 bar(g)-nak bizonyult.

A hőmérséklet mellett a betáplálás összetétele is hatással van az LEP értékére. Elektrolitok esetében (mint például a tengervíz) a növekvö koncentráció növeli a felületi feszültséget, csökkentve a nedvesedés esélyét, míg a szerves vegyületek és felületaktív anyagok csökkentik azt (7. ábra). Ezáltal az LEP kiemelten fontos tényező, ha ezek a komponensek is jelen vannak a betáplálásban, mivel jelenlétükben Young-Laplace (5) egyenlet értelmében a $\gamma_{L} \cos \theta$ szorzat értéke csökkenhet, így növelve a pórusok nedvesedésének veszélyét. Azt az összetételt, amely mellett a membrán spontán nedvesedik a betáplált folyadékelegytől, kritikus összetételnek nevezzük.

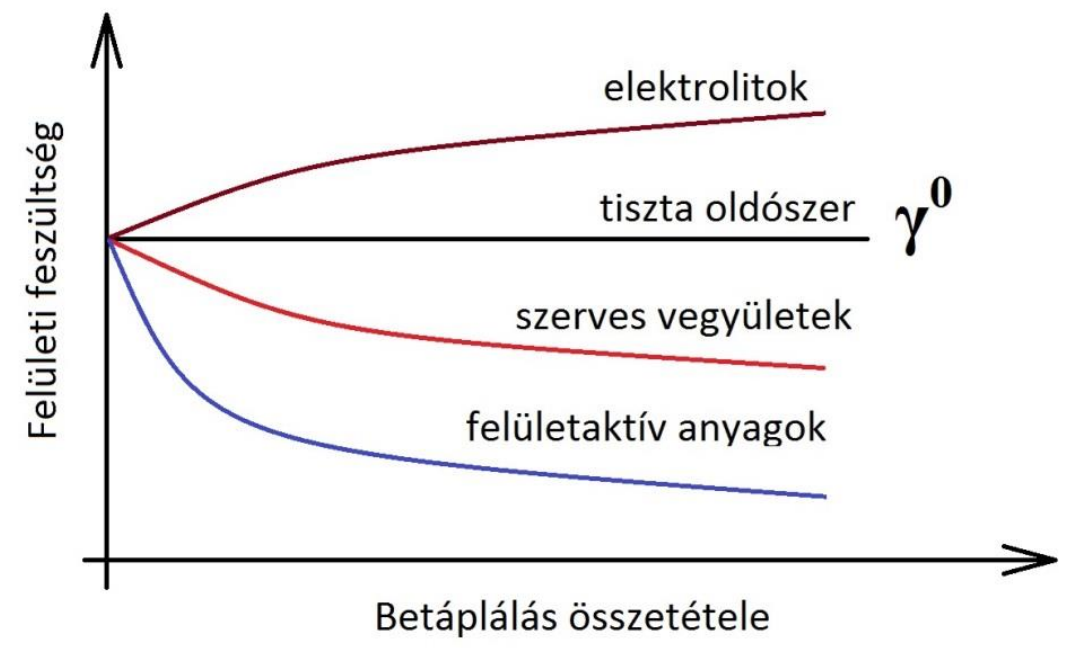

7. ábra A felületi feszültség változása különböző anyagok növekvő koncentrációja esetén

\subsubsection{A membrán pórusok nedvesedésének hiszterézises jelensége}

A 8. ábrán a membránpórusok nedvesedése után fenálló hiszterézis-jelenséget figyelhetjük meg. Amint az látható, a transzmembrán nyomáskölönbség növelésével (1. szakasz) az LEP érték eléréséig nem figyelhetünk meg folyadékállapotú szürletet, ekkor ugyanis a kapilláris erők megóvják a pórusok közvetlen nedvesedését a folyadékállapotú betáplálástól. Viszont az LEP érték elérésétől kezdve egyre több pórus kezd átnedvesedni (2. szakasz), így folyadékállapotú szürletet kapunk a membrán másik oldalán. Ekkor a membrán fokozatosan elveszíti azt a képességét, mely lehetővé teszi a membrándesztillációt, és átlagos pórusméretének megfelelően mikroszürőként müködik tovább. Abban az esetben, ha akkora nyomáskülönbséget biztosítunk, mely elegendő az összes pórus nedvesítéséhez, 
ez után a nyomáskülönséget csökkentve egy lineáris összefüggéshez jutunk (3. szakasz), és az ábrán látható módon a folyadékállapotú szürlet és a transzmembrán nyomáskülönbség jelensége máshogy zajlik le. Ez a jelenség a hiszterézis.

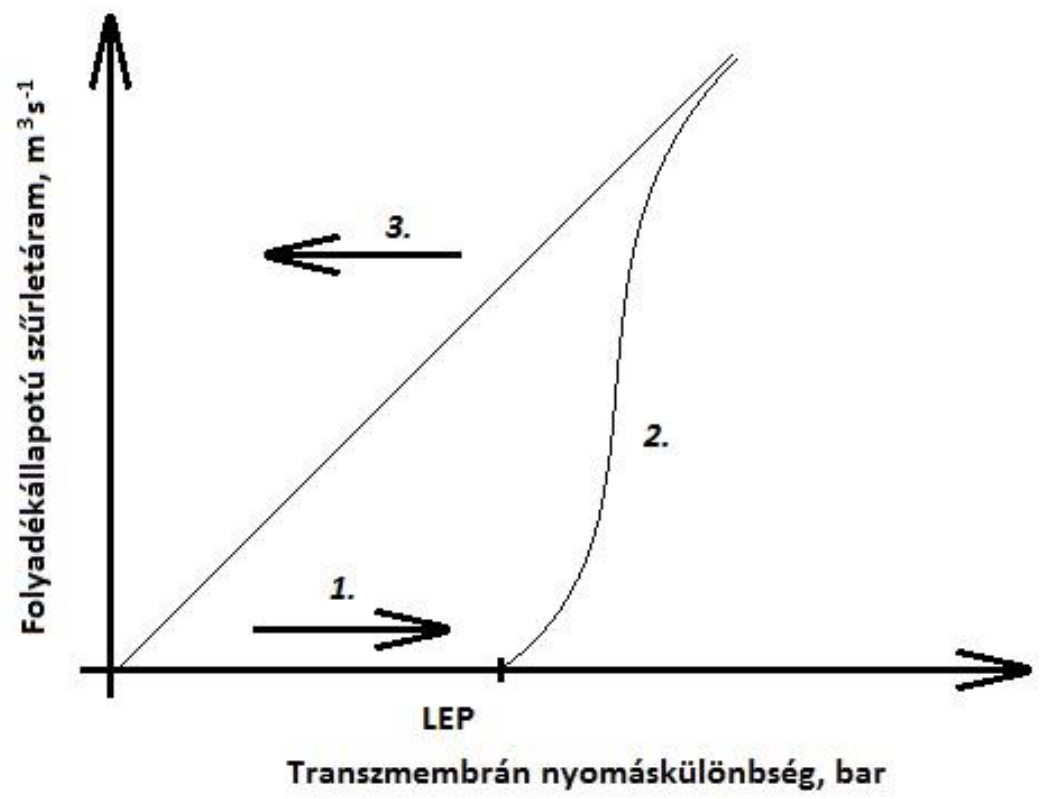

8. ábra A hiszterézis jelensége desztillált víz betáplálás mellett (LAWSON 1997)

Ha a membrán pórusai elárasztódtak, tovább nem alkalmas membrán desztillációs feladatok elvégézésére, egészen addig, amíg egy regenerációs eljárás segítségével a pórusokban lévő nedvességet teljes egészében el nem távolítottuk. Erre a regenerálási eljárásnak a vizsgálatára nem található szakirodalmi forrásmunka.

\subsubsection{LEP mérése statikus módszerrel az irodalomban}

A pórusok nedvesedése a termék minőségének romlásához vezet, ezért nagyon fontos ennek ismerete és az, hogy az LEP értéke a lehetö legmagasabb legyen. Az (5)-ös modell több feltételezésen alapszik. A pórusok alakjára vonatkozó $B$ faktor értékét gyakran a hengeres pórushoz tartozó értékkel helyettesítjük, habár a pórusok alakja a valóságban ettől jelentősen eltérhet. FRANKEN és mtsai (1987) korai tanulmányukban rámutattak, hogy ebből kifolyólag érdemes az LEP értékét inkább kísérleti úton meghatározni, mint számítással megbecsülni.

Az LEP mérésére többféle módszert is alkalmaztak a kutatók ezidáig. Ezek közös jellemzője, hogy hasonló, statikus müveleti körülmények mellett vizsgálták az LEP értékét, azaz a közeg(ek) nincsenek mozgásban, szemben egy valódi müveleti eljárással. KYAHET és mtsai (2001) új PVDF 
membrándesztillációs lapmembrán készítésének folyamatát vizsgálták, és az elkészült membrán jellemzésére többek közt az $\mathrm{LEP}_{\mathrm{w}}$ értéket jelölték meg, mint fontos, kritikus paramétert. Ennek az értéknek a meghatározását kísérleti módszerrel végezték, a kísérleti berendezés sematikus képe a 9.a) ábrán látható.

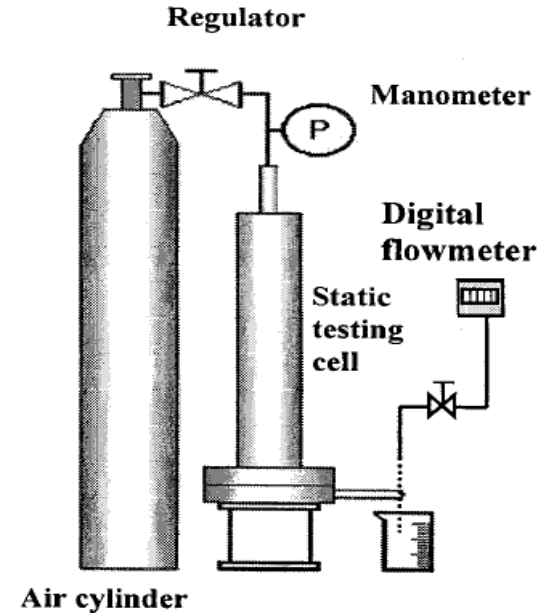

a.)

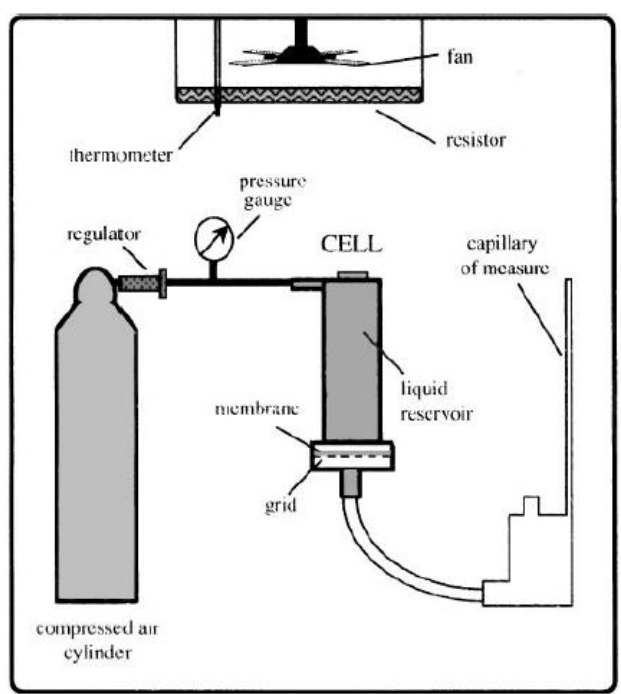

b.)

9. ábra LEP ${ }_{\mathrm{w}}$ meghatározása kísérleti úton: a.) KYAHET (2001) szerint, b.) GARCÍA-PAYO (2000) és mtsai szerint

A membrán egy vízszintes rozsdamentes acél cellában feküdt egy felső és egy alsó kamra között. A felső kamra tiszta vízzel volt feltöltve, az alsóhoz pedig egy digitális áramlásmérőt csatlakoztattak. A felső, vízzel töltött kamrához továbbá egy levegőtartályt csatlakoztattak. A felső, vízzel tötlött tartály nyomását a levegővel kismértékü túlnyomás ( 0.3 bar(g)) alá helyezték, 10 percig. Ezt követően, lépésenként, mindössze 0,0068 bar(g) egységenként növelték a nyomást. Ahol egy folytonos folyadékáramlást tudtak észlelni a digitális áramlásmérővel a desztillátum oldalon, azt nevezték az LEP ${ }_{w}$ értékének. Smolder (1989) korai munkájában szintén ezt a módszert találhatjuk.

Hasonló módszert alkalmaztak GARCÍA-PAYO és mtsai (2000), PVDF és PTFE membránok LEP értékeit vizsgálták desztillált vízzel, valamint etil-alkohol- víz eleggyel szemben. A 9.b.) ábrán látható, hogy az előző módszerhez képest a digitális áramlásmérő helyett a desztillátum oldalon, egy $1 \mathrm{~mm}$ belső átmérőjü kapilláriscsőt alkalmaztak, ami fel volt töltve desztillált vízzel, vagy etil-alkoholvíz eleggyel, így egy állandó meniszkusz szint volt megfigyelhető. Az előző módszerhez hasonlóan az alkalmazott hidrosztatikai nyomáskülönbséget lépésenként növelték egy gáztartály segítségével a 
membrán feletti térrészben. Az LEP érték elérésének pillanatában az alsó részhez kapcsolt meniszkusz szint elmozdult, jelezve a megnövekedett nyomást és folyadékmennyiséget, ezt az elmozdulást cathetometer segítségével mérték.

A 10. ábrán látható módszert is alkalmazták az LEP meghatározására (HE et al. 2011). A membráncella $20 \mathrm{~mm}^{-1} \%$-os sóoldatot tartalmazott, melyet egy desztillált vízzel feltöltött kádban helyeztek el. A túlnyomást $\mathrm{N}_{2}$ gáztartály biztosította. A desztillált vizet tartalmazó kádban konduktométerrel követték nyomon a vezetőképességet, és túlnyomást alkalmazva az LEP értéket elérve a $\mathrm{NaCl}$ oldat áthaladt a membránon, ezzel ugrásszerű változást okozva a víz vezetőképességében. Az ugrásszerü változáshoz tartozó nyomásérték jelentette az LEP értékét $20 \mathrm{~mm}^{-1} \%$-os $\mathrm{NaCl}$ oldat nedvesítése során.

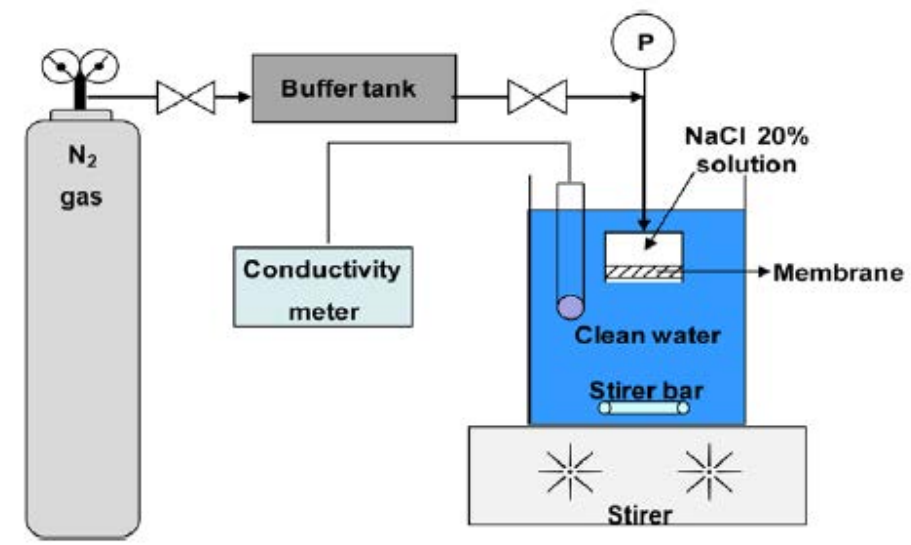

10. ábra LEP meghatározása (HE et al. 2011)

Még ezen ismeretek függvényében is a pórusátmérőt egy adott feladathoz úgy kell választanunk, hogy a lehető legnagyobb legyen, mivel így növelhetjük a gőz-folyadék határfelületeket, viszont ezzel szemben növelhetjük a nedvesedés esélyét is. Így ennek megválasztása nagy körültekintést, valamint megfontolt kompromisszumot igényel. Emellett a pórusátmérő - eloszlásának széles tartománya is növelheti a nedvesedés esélyét, így érdemes olyan membránt választani, esetleg fejleszteni, melynek ez a tartománya a lehető legszükebb érték.

A felsorolt publikációkat szemügyre véve látható, hogy az irodalom a statikus módszeren kívül más módszert nem ismertet, tehát ezek alapján nem tudhatjuk, hogy vajon valós körülmények mellett, amikor a közegek áramolnak, hogyan viselkedik, változik-e az LEP értéke a statikus módszerrel szemben. Munkámmal többek közt erre kívánok választ adni, illetve megoldást nyújtani. 


\subsubsection{A membrán- és ozmotikus desztilláció alkalmazási területei}

A számos elméleti, a folyamat általános hatékonyságának növelésére fókuszáló kutatás mellett a membrándesztilláció szabadalmazása óta (BODELL 1963; FINDLEY 1967) rendkívül sokféle alkalmazást is vizsgáltak a különböző kutatócsoportok. A teljesség igénye nélkül ezek közül emelem ki a legfontosabbakat, illetve az érdekesebb alkalmazásokat.

\subsubsection{Sós víz, tengervíz sótalanítás, talajvíztisztítás}

A membrándesztilláció összes alkalmazási lehetősége közül talán a legnagyobb jelentősége a tengervíz sótalanításának van. Az ivóvíz hiánya a forróövi országok számára mindig komoly problémát jelentett, de a világ népességének folyamatos növekedésével és a vízkészletek egyre nagyobb mértékü szennyezettségével várhatóan a megfelelő mennyiségü és minőségủ ivóvíz zavartalan előállítása és szolgáltatása hamarosan az egész világon kardinális problémává válik. Azokban az országokban, ahol magas az egy évre jutó napsütéses órák száma, ott a napenergia felhasználása egyértelmünek mutatkozik, de egyéb megújuló energiaforrásokat is képes hasznosítani egy membrán desztilláció rendszer, ilyenek például a geotermikus energia, vagy akár a szélenergia (AMALI et al. 2004). A 2000es évek közepétől fogva a világ legkülönbözöbb pontjain kezdtek el foglalkozni félüzemi és nagyobb teljesítményü membrándesztillációs berendezések, telepek fejlesztésével és telepítésével e célok megvalósítására.

A MEDESOL (MEmbrane DEsalination SOLar energy") projekt, öt ország konzorciumának eredménye (Spanyolország, Portugália, Németország, Mexikó, Svédország), innovatív, napenergiával működő tengervíz sótalanító rendszer fejlesztését foglalja magában (GÁLVEZ et al., 2009). Célja olyan nagy hatásfokú, költséghatékony membrándesztillációs rendszer tervezése volt tengervíz sótalanítására napi $0,5 \mathrm{~m}^{3}-50 \mathrm{~m}^{3}$ termelékenység mellett, mely konstrukciós egyszerüséggel, hosszú karbantartásmentes üzemeltetési időszakkal, kiváló minőségủ ivóvíz előállításának képességével bír. A szükséges hőt napkollektorok szolgáltatják, ezeket a speciális napkollektorokat a konzorcium megfelelő tagjai fejlesztették. Az alkalmazott membrándesztillációs konfiguráció AGMD volt. A projekt eredményeként a rendszer eleget tesz a fenntartható fejlődés követelményeinek még olyan területeken is, ahol az elektromos hálózat müködése megbízhatatlan, vagy az egyáltalán nem érhető el. Sikeresen növelte a napenergia müködtette MD folyamat hatékonyságát a már létező, félüzemi berendezésekkel szemben is, valamint költséghatékony tud lenni összehasonlítva olyan rendszerekkel szemben, mint a hagyományos napkollektoros desztillációs rendszerek: napkollektoros többlépcsős flash-desztilláció (,,MSF - Multi-stage flash”), illetve napkollektoros többtestes bepárlás (,,MED-multieffect distillation"). 
Hasonlóan, membrándesztillációval történő tengervíz sótalanítását valósították meg félüzemi körülmények között AGMD konfigurációban a Memstill ${ }^{\circledR}$ program keretén belül, ami egy kilenc tagot magában foglaló konzorcium volt. A berendezést Szingapúrban, Senoko városában 2006-ban telepítették, egy hulladékgyüjtő égetőmüben keletkező hőt alkalmazva. A Keppel Seghers vállalat, a konzorcium egyik tagja végezte a kivitelezést, ezt követően pedig Hollandiában további megvalósítások folytatódtak. A szingapúri berendezés teljesítménye 1-2 $\mathrm{m}^{3} \mathrm{~h}^{-1}$ (HANEMAAIJER 2004; HANEMAAIJER et al. 2006).

Üzemi méretủ spirál tekercs modult felhasználó membrándesztillációs berendezést valósítottak meg sótalanítási feladatra WINTER és mtsai (2011). Az alkalmazott hasznos membrán felület 5-14 $\mathrm{m}^{2}$ volt, PTFE anyagból készült, 0,2 $\mu \mathrm{m}$-es névleges pórusmérettel. A müvelet elvégzésére egy speciális konfigurációt alkalmaztak, amit „Permeate Gap Membrane Distillation”-ek neveztek el, (gyakorlatilag a 3. ábrán bemutatott LGMD-val megegyező elven müködik, csak a membránt egy spirál tekercs modulba tekerik fel a kompakt modulkialakítás és a hatékony hőcsere érdekében). A 11. ábra demonstrálja a modul elvi alapjait.

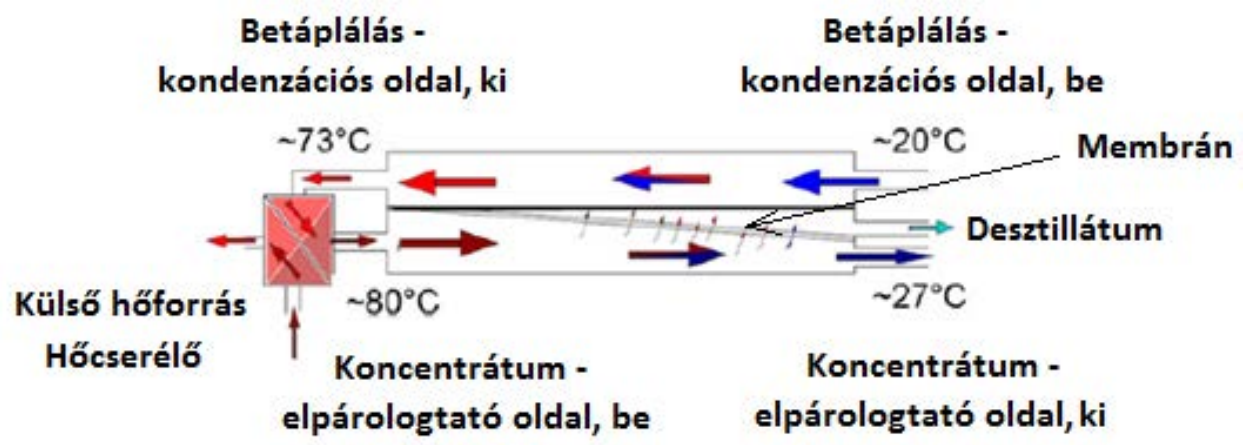

11. ábra PGMD konfiguráció WINTER nyomán (2011)

Vizsgálták a fajlagos energiafelhasználást számos müveleti paraméter mellet, és vizsgálták ezeknek a paramétereknek a hatását. Eredményként $10-25 \mathrm{kgh}^{-1}$ tömegáramú, maximum 3,5 $\mu \mathrm{Scm}^{-1}$ vezetőképességü desztillátumot tudtak elöállítani 130-207 $\mathrm{kWhm}^{-3}$ fajlagos hőenergiafelhasználás mellett. Az előkísérletek során sikeresen tudtak akár $0,19 \mu \mathrm{Scm}^{-1}$ vezetőképességü desztillátumot előállítani. Továbbá megállapították, hogy a betáplálás áramlási sebességének nagy hatása volt a müveletek hatékonyságára különböző hömérsékletkülönbség és hidrodinamikai paraméterek mellett. További meghatározó változónak a betáplálás sókoncentrációja mutatkozott. A magasabb sótartalom kisebb gőznyomás különbséget eredményezett, ezen keresztül csökkentve a folyamat hajtóerejét. 10 $\mathrm{gkg}^{-1}$ sókoncentráció növelés $10 \mathrm{kgh}^{-1}$ desztillátum fluxus csökkenést eredményezett. 
További fontos membrándesztillációs sótalanítási kísérleteket végeztek a Kanári-szigetcsoport Grand Canaria szigetén. A 2004-ben, a MEMDIS projekt keretén belül megvalósított sótalanító berendezés vizsgálatát a MEDIRAS projekt folytatta (RALUY et al. 2012). A félüzemi berendezés legfontosabb jellemzői:

- Névleges desztillátumelőállítási kapacitás: 7-20 $\mathrm{Lh}^{-1}$

- Napenergiával felfütő hőcserélő hatásos felülete: $6,96 \mathrm{~m}^{2}$ (3 sík kollektor párhuzamosan)

- Napelem: $80 \mathrm{Wp}$ (a recirkulációs pumpa és a vezérlő rendszer részére)

- Tengervíz betáplálás (patron előszürt)

- 500 L-es puffer tengervíz tartály, ami a tengervíz kúthoz csatlakozik, újratöltő szivattyúval

- Membrándesztillációs modul hatásos felülete: 8,5 m²-10 m² (PGMD konfiguráció)

- Modulba belépő hőmérséklet: $60-80{ }^{\circ} \mathrm{C}$ (ez az a hőmérséklet-tartomány, ahol a napenergiával felfütő hőcserélő hatékonyan müködik)

- Pnévleges: 1 bar

- Nyári, napi üzemóra: 8-9 h

A tengervízből való ivóvíz előállítása mellett különböző felszín alatti vizek tisztításának lehetőségét is vizsgálták a kutatók. A talajvíz magas arzéntartalma komoly probléma a világ legkülönbözőbb pontjain, az Egyesült Államok délnyugati részétől kezdve, Taiwanon, Thaiföldön, Kínán és Indián keresztül, vagy akár Kelet-Közép-Európán, Magyarországon át. Az arzén az élő szervezetre toxikus, elősegítheti daganatos betegségek kialakulását, de különböző kardio-vaszkuláris, immunológiai, neurológiai és endokrin megbetegedéseket is okozhat.

Talajvíz arzén mentesítését is elvégezték napenergia müködtette membrándesztillációs berendezéssel, DCMD konfigurációban PAL és MANNA (2010). A kísérlethez PTFE és PP membránokat használtak, egyenként 0,0120 $\mathrm{m}^{2}$-es felülettel, keresztáramban müködtetve. A kísérletekhez szükséges talajvizet Indiából, Nyugat-Bengáliából szerezték be. Vizsgálták a betáplálás kiindulási arzén koncentrációjának (0-1200ppb), a betáplálás áramlási sebességének és hőmérsékletének $\left(30-61^{\circ} \mathrm{C}\right)$, valamint az alacsonyabb hőmérsékletü desztillált víz modulba belépő hőmérsékletének hatását az arzén visszatartás hatékonyságára és a müveletet fluxusára. Azt tapasztalták, hogy még 120 óra üzemeltetés mellet is 100\%-os arzénvisszatartást sikerült elérni, a membrán pórusai nem nedvesedtek, a legnagyobb fluxus, amit elértek $49,80 \mathrm{kgm}^{-2} \mathrm{~h}^{-1}$ volt. A betáplálás áramlási sebességének és hőmérsékletének növelésével a folyamat hatékonyabbnak bizonyult, a 
desztillátum áramlási sebessége is növelte a desztillátum fluxust, viszont a desztillátum hőmérsékletének növelése, valamint a kezdeti arzén koncentráció növekedése csökkentette a folyamat hatékonyságát.

As(III) és As(V) ionok eltávolítását is vizsgálták DCMD konfigurációval, saját gyártású PVDF membránnal QU és mtsai (2009). A legnagyobb fluxus 20,90 $\mathrm{kgm}^{-2} \mathrm{~h}^{-1}$-nak bizonyult. Kiváló visszatartást értek el ebben a rendszerben, ennek mértéke függött a hőmérséklettől és a pH-tól. Általánosságban megállapítást nyert, hogy a hagyományos membránszürési eljárásokhoz képest hatékonyabb szétválasztást sikerült elérni membrándesztilláció alkalmazásával, a desztillátum maximális arzénkoncentrációja $10 \mu \mathrm{gL}^{-1}$ volt 40-2000 mgL ${ }^{-1}$ betáplálás arzénkoncentráció mellett.

Szennyezett talajvizet modellező oldatból arzént, uránt és fluoridot is távolítottak el membrándesztillációval, DCMD konfigurációban (YARLAGADDA et al. 2011). PP és PTFE membránokat használták, vizsgálták a permeabilitást és a sóvisszatartást, a betáplálás 100-10000ppm arzén, 10-400 ppm urán, 1-30 ppm fluorid volt. Ebben az esetben is nagyon hatékony, 99 \%-os sóvisszatartást értek el, ami kiváló lehetőséget jelenthet ivóvíz előállítására szennyezett talajvízből, különösen akkor, ha könnyen hozzáférhető hulladékhöt tudunk felhasználni a folyamat végrehajtásához.

\subsubsection{Ipari szennyvíztisztítás}

A különböző ipari folyamatok során keletkező szennyvizek megfelelő kezelése kulcskérdés a fenntarthatóság szempontjából. A gyárak a legkülönbözőbb biológiai, fizikai és kémiai eljárásokat alkalmazzák a megfelelő határértékek betartására, az előzőekben bemutatottak alapján ennek egyik lehetséges alternatívája lehet a membrándesztilláció is. Ha az adott technológiában hulladékhő is keletkezik, ennek alkalmazásával különösen bíztató lehetőségek adódhatnak. Számos ipari területröl származó szennyvizek kezelésének lehetőségét vizsgálták már membrándesztillációval.

Az egyik tanulmányban ZAKRZEWSKA-TRZNADEL és mtsai (1999) kis radioaktivitású szennyvizek koncentrálásának lehetőségét vizsgálták membrándesztillációval. Ennek a nagy mennyiségben keletkező radioaktív anyagnak a kezelése nem tartozik a szokványos ipari szennyvizek kezelésének körébe, speciális eljárást igényel. A fö cél a radioaktív komponensek koncentrálása a további, hatékonyabb kezelés, vagy lerakás érdekében. Tanulmányuk kimutatta, hogy a jelenlevő összes radioaktív komponenst képes visszatartani a membrándesztillációs membrán, így a kapott desztillátum gyakorlatilag tiszta víz, amit biztonságosan fel lehet használni más területeken, illetve 
vissza lehet engedni a környezetbe. A szerzők azt is bemutatták publikációjukban, hogy a nukleáris reaktorok hütővizének hulladékhője kiválóan alkalmazható a membrándesztilláció megvalósítására.

Kőolaj kitermelésből származó, nagy oldott sótartalmú vizet, valamint kitermelési szennyvizet szimuláló modellelező oldatot (,,produced water”, $P W$ ) választottak szét DCMD konfigurációban, egy másik tanulmányban (SINGH és SIRKAR 2012). PTFE lapmembrán alkalmaztak 0,03 $\mu \mathrm{m}$ pórusmérettel, a betáplált sóoldat $10000 \mathrm{ppm} \mathrm{NaCl-ot} \mathrm{tartalmazott,} \mathrm{és} \mathrm{a} \mathrm{PW-t} \mathrm{modellező} \mathrm{elegy}$ összetétele 3000 ppm NaCl, 45 ppm fenol, 45 ppm krezol és 10 ppm nafténsav volt. A vizsgálatokat 80-130 ${ }^{\circ} \mathrm{C}$ betáplálási hömérsékleteken, és 2-3 bar(a) nyomáson végezték és ebben a tartományban $\mathrm{NaCl}$ nem hatolt át a membránon. A legnagyobb fluxus $195 \mathrm{kgm}^{-2} \mathrm{~h}^{-1}$ értéknek adódott, ami jelentősen magasabb, mint fordított ozmózis alkalmazása esetén, ami a magas hőmérésklethez tartozó magas gőznyomásértéknek tulajdonítható be. A keletkezett desztillátumot HPLC, valamint GC-EI-MS müszeres analitikai elemzésnek vetették alá. Ez kimutatta, hogy csekély mértékủ, mindössze 5 ppm érték körüli fenol, valamint krezol jelentkezett a desztillátumban, 2 ppm körüli érték volt mérhető a nafténsavra vonatkozólag, a sótartalmat pedig teljes egészében visszatartotta a membrán.

\subsubsection{Vegyipar, fermentációs eljárások, gyógyszeripar}

Az eddig bemutatott alkalmazási területeken a termék a tiszta víz volt. Ebben az alfejezetben viszont a cél bizonyos értékes komponensek kinyerése, koncentrációjának növelése egy oldatban, vagy pedig különböző komponensek elválasztása gőz-folyadék egyensúlyuk alapján, mint például illékony szerves komponensek, alkoholok, illékony zsírsavak.

Vegyipari alkalmazások tekintetében széles körü lehetőségeket kutattak már eddig. Alacsony koncentrációjú, $100 \mathrm{mgL}^{-1}$ ammóniát tartalmazó modell oldat szeparálását végezték SGMD konfigurációban XIE és mtsai (2009). Különböző műveleti paraméterek hatását vizsgálták a művelet hatékonyságára, az ammónia eltávolításának mértékére. Ilyen paraméterek a betáplálás hőmérséklete, betáplálás áramlási sebessége, az inert gázáramlási sebessége. Az eredmények azt mutatták, hogy kritikus műveleti paraméter a betáplálás hőmérséklete, ennek az értéknek az emelése növekvő desztillátumfluxust eredményez, viszont rontja a szétválasztás mértékét. A legnagyobb fluxust a legmagasabb hőmérsékleten és legnagyobb gázáramlási sebesség mellett tudták elérni, így 97\%-os ammónia eltávolítást sikerült elérniük, és a kezelt vízben az ammónia értékét $3,3 \mathrm{mgL}^{-1}$-ra csökkentették. 
További ammóniamentesítést is vizsgáltak más konfigurációkban is (DING et al. 2006). A tanulmányban három membrándesztillációs konfigurációt (VMD, DCMD, SGMD) hasonlítottak össze, vizsgálták az anyagátadási együttható és a szeparációs tényező értékének változását a legfontosabb müveleti paraméterek változtatása mellett (membránjellemzők, betáplálás hőmérséklete, betáplálás és desztillált víz/inert gázáramlási sebessége, kezdeti ammóniatartalom és $\mathrm{pH}$ ). Eredményként a legnagyobb anyagátadási tényezőt a VMD-vel érték el, viszont itt lett a legkisebb a szétválasztás hatékonysága. A DCMD konfiguráció esetében volt a legjobb a szétválasztás, viszont az anyagátadási együttható itt adódott a legkevesebbnek. Az SGMD esetében az anyagátadási együttható és a szétválasztási tényező is mérsékelt volt.

Amikor az alkoholok és egyéb illékony szerves komponensek a vízzel elegyet képeznek, ezeknek az elegyeknek a szétválasztására a hagyományos eljárások tekintetében számtalan megoldás létezik. Ilyen széles körben elterjedt módszer az extraktív desztilláció, azeotróp desztilláció, hagyományos, továbbá a kétnyomásos rektifikálás, stb. A vizsgálatok azt mutatják, a membrándesztilláció is egy lehetséges alternatíva lehet erre a feladatra.

Aceton-víz és etanol-víz elegy szeparálását is végezték SGMD konfigurációval (BOI et al. 2005). Vizsgálták a betáplálás hőmérsékletének, összetételének, áramlási sebességének hatását, valamint az inert $\mathrm{N}_{2}$ gáz áramlási sebességének hatását a szeparáció hatásfokára. A párolgás sebessége erősen függ a hőmérséklettől, így a folyamat sebessége itt is nagyobb a magasabb hőmérsékleten történő üzemeltetésen. Az inert gáz áramlási sebességének növekedése enyhén növelte a folyamat fluxusát, bár ezzel párhuzamosan kissé csökkentette a szerves fázis koncentrációját a desztillátumban. A betáplálás térfogatáramának növelése mind a fluxust, mind pedig a szétválasztás hatékonyságát növelte.

Alacsony koncentrációjú izopropil-alkohol-víz elegy szétválasztására vizsgálták SGMD konfigurációban (LEE 2001). A desztillátumfluxust határozták meg, miközben változtatták a betáplálás összetételét, térfogatáramát, a müveleti hőmérsékletet, valamint az inert gázáram belépési hőmérsékletét és térfogatáramát. Továbbá vizsgálták az oldathoz $5 \mathrm{~mm}^{-1} \%$-ban hozzáadott $\mathrm{MgCl}_{2}$ só hatását. Kapilláris, PTFE modult használtak, a legnagyobb izopropil-alkohol koncentráció $10 \mathrm{~mm}^{-1} \%$ volt. $20-50{ }^{\circ} \mathrm{C}$-os hőmérséklet-tartományban a szétválasztási tényező értéke 10-25 között volt mérhető. A hőmérséklet növelésével a desztillátumfluxus és az izopropil-alkohol szelektivitása nőtt, a betáplálás térfogatárama ugyanolyan hatással volt mind a fluxusra, mind a szelektivitásra, viszont az inert gázáram hőmérsékletének hatása elhanyagolható volt. A kritikus paraméter az inert gázáramlási 
sebessége volt, ennek növelése jelentősen növelte a folyamat sebességét. A só szerepét tekintve a desztillátumfluxus tekintetében csak kismértékü csökkenés volt érzékelhető, szelektivitást nézve szignifikáns csökkenés volt kimutatható, viszont a só a membránon nem haladt át, mindössze $2 \mu \mathrm{Scm}^{-1}$ vezetőképességet mértek, ami gyakorlatilag 100\%-os sóvisszatartást jelent.

Illékony szerves komponensek (VOCs) eltávolítását végezték vákuum-membrándesztillációval, vegyipari szennyvízből (BANAT 1995). Kapillárcsöves polipropilén membránt alkalmaztak alacsony koncentrációjú benzol-víz elegy szétválasztására. A vizsgálat során a benzol áthaladása a membránon bizonyítást nyert. Vizsgálták a különböző müveleti paraméterek hatását, a betáplálás összetételét, térfogatáramát, hőmérséklet és nyomás hatását. Azt találták, hogy az elegy kiindulási benzol koncentrációja nem gyakorol hatást az anyagátbocsátási tényező értékére. A nagyobb alkalmazott vákuum növeli a desztillátumfluxust, viszont csökkenti a szelektivitást. A növekvő betáplálási sebesség növelte az anyagátbocsátási koefficiens értékét.

COUFFIN és mtsai (1998) olyan ipari szennyvizek tisztításának lehetőségét vizsgálták, melyek különböző illékony, szerves halogénvegyületeket tartalmaznak, mint például triklór-etilén vagy tetraklór-etilén. $400 \mu \mathrm{gL}^{-1}$ triklór-etilént tartalmazó vizes közegből vákuum-membrándesztillációs berendezéssel távolították el a szerves fázist. A betáplálás és desztillátum triklór-etilén tartalmát GC-ECD müszerrel követték nyomon. A betáplálás áramlási sebessége $0,23 \mathrm{~ms}^{-1}$ sebességü volt, ami $\operatorname{Re}=550$ jelentett, $30{ }^{\circ} \mathrm{C}$-on. A desztillátum oldalon a hőmérséklet értékét $30-50{ }^{\circ} \mathrm{C}$ között változtatták, és 10-70 mbar(a) közti vákuumértéket alkalmaztak. A teljes desztillátumfluxus csökkent a magasabb abszolút nyomással, illetve az alacsonyabb hőmérséklettel. Ezzel szemben viszont a szelektivitás nőtt az alacsonyabb nyomással, és csökkent a magasabb hőmérséklettel. Ez arra a következtetésre juttatta a szerzőket, hogy az alacsonyabb müveleti hőmérséklet $\left(30^{\circ} \mathrm{C}\right)$ és magasabb nyomás, azaz mérsékelt vákuum (30-35 mbar(a)) nyomás tartományban hatékony a folyamat. Ez, mint optimum jelent meg a vizsgálat során, mivel így a legkedvezőbb az energiafelhasználás, és a szelektivitási tényező értéke elérte a 860-as értéket. Érdemes megemlíteni, hogy a tertraklór-etilén fluxusa elég alacsony az összes fluxushoz viszonyítva, és magára a tertraklór-etilén fluxusára nincs nagy hatása az alkalmazott vákuumnak, rögzített hőmérsékleti értékek mellett a vákuum mértékének változtatása nem okozott jelentős változást a vizsgált 10-70 mbar(a) tartományban. Továbbá a tertraklór-etilén fluxusa nagyobbnak bizonyult $30^{\circ} \mathrm{C}$-on, mint $40^{\circ} \mathrm{C}$, illetve $50^{\circ} \mathrm{C}$-on.

Különböző szervetlen és szerves savak koncentrálását végezték membrándesztillációval DCMD konfigurációban (TOMASZEWSKA, 1995). Szervetlen savak közül kénsav oldatot, foszforsav oldatot, 
sósav oldatot és salétromsav oldatot, szerves savak közül pedig citromsav oldatot koncentráltak. A betáplálás hőmérséklete $50-60{ }^{\circ} \mathrm{C}$ volt, és $20-25{ }^{\circ} \mathrm{C}$ volt a hidegoldali desztillált víz hőmérséklete. Kimutatták, hogy a magasabb savkoncentráció csökkenti a desztillátum fluxust. A nem illékony savak esetében a visszatartás 100\%-os volt, valamint független volt a betáplálás koncentrációjától, viszont sósav és salétromsav esetében ezek koncentrációja a desztillátumban növekedett a koncentrációval a betáplálásban az azeotróp pont eléréséig.

Textiliparban képződő szennyvíz kezelésére is találunk példát, itt a festőanyagok nem, illetve kevésbé illékony mivoltuk alapján javarészt visszamaradnak, ezáltal a tiszta víz előállítása és az értékes festőanyagok visszanyerése megvalósítható. Öt különböző ipari textilfestékből előállított modell oldatokat szeparáltak VMD konfigurációval, a festőanyagok kiindulási koncentrációja 25-500ppm között volt (CRISCUOLI et al. 2008). A membrándesztilláció használata itt azért előnyös, mivel a festőfürdő hőmérséklete $80-90{ }^{\circ} \mathrm{C}$, így külön energia befektetése a betáplálás felmelegítésére nem szükséges. Az alkalmazott vákuum értéke 10 mbar(a) volt. Spektrofotométerrel mérték a festékoldatok koncentrációját, mind a betáplálás, mind pedig a desztillátum oldalon. A müvelet során a festőanyagokat 100\%-ig visszatartotta a membrán, ezáltal a festékek koncentrálása sikeres volt. Vizsgálták a betáplálás hőmérsékletének, áramlási sebességének hatását, és a festékoldat kiindulási koncentrációjának hatását a folyamat hatékonyságára. Az eredmény megegyezett a vártakkal, mind a hőmérsékletnek, mind pedig az áramlási sebességnek pozitív hatása volt a desztillátumfluxusra. A kiindulási koncentrációt tekintve ez a hatás ellentétes, nagyobb érték kisebb desztillátumfluxust eredményezett. Érdekes jelenség, hogy a festéket tartalmazó oldat fluxusa nagyobb volt, mint a tiszta, desztillált vízzel elért fluxus. A szerző ezt a festőanyag és a polimer membrán interakciójának tulajdonítja, miszerint a membrán megduzzadt a festőanyag hatására, ezzel javítva a hatékonyságot. Alapos mosás után, megszabadítva a membrán felületét a festékanyagoktól, a kiindulási fluxus ismét mérhető volt desztillált vízzel.

GRYTA (2001) bioetanol fermentációját végezte Saccharomyces cerevisiae-vel, a fermentációjából származó fermentlé szeparálása DCMD konfigurációban történt. A fermentáció során képződő alkohol és egyéb illékony szerves metabolit molekulák gátolják a fermentációt, így azok eltávolítása egy folytonos rendszer alkalmazásával nagyobb produktivitáshoz vezet. Az általuk vizsgált bioreaktorral összekapcsolt MD berendezés sikeresen állított elő nagyobb alkohol tartalmú desztillátumot, mint a betáplálás (2-6-szor nagyobb koncentráció), és ezen keresztül a csökkentett etanol tartalom a betáplálásban növelte a szétválasztási koefficiens értékét. Az alkalmazott 
hőmérsékletkülönbség $20^{\circ} \mathrm{C}$ volt. A permeabilitás mértéke a folyamat során nem csökkent, amely azt bizonyítja, hogy a sejtek nem tapadtak meg a membrán felületén. A membrán felületet SEM módszerrel megvizsgálták a fermentáció előtt és után, ami ezt az állítást alátámasztotta. Továbbá a diszpergált inaktív élesztősejtek jelenléte csökkentette az MD folyamat hatékonyságát, $10 \mathrm{~g}$ liofilizált sejt hozzáadása a rendszerhez több mint 50\% fluxuscsökkenést eredményezett a MD folyamatában. A fermentáció során képződő szén-dioxid buborékok elősegítették a keveredés mértékét, így csökkentve az anyagátadási határréteg mértékét, növelve a fluxus hatékonyságát. GRYTA (2002) további vizsgálatokat is végzett. LEWANDOWICZ (2011) is végzett fermentációs kísérleteket hasonló eredményekkel.

Tradicionális kínai gyógynövény kivonatot koncentráltak membrándesztillációval DCMD konfigurációban DING és mtsai (2008), ginseng kivonatot koncentráltak vákuummembrándesztillációval ZHAO és mtsai (2011). Az analitikai kémiában is alkalmazzák a membrándesztillációt (GETHARD és MITRA 2011). Az orvoslás gyakorlatában, izotópos vizsgálatoknál is alkalmazható a membrándesztilláció (KIM 2004).

\subsubsection{Olaj-víz emulzió szétválasztása}

Olaj-víz emulzió szétválasztását különböző hagyományos membránszürési eljárásokkal, mikroszüréssel és ultraszüréssel már többen kutatták (NANDI 2009; SINGH 2011). Ezzel szemben példát olaj-víz diszperz rendszerek membrándesztillációval való szétválasztására a szakirodalomban csak elvétve találunk (GRYTA és KARAKULSKI 2001) annak ellenére, hogy az iparban jelentős szennyező forrás lehet az olaj, és annak egy része emulziót alkotva jelenik meg.

KARAKULSKI (1995) korábbi munkájában bemutatott kísérletben a cseppek eloszlásának tekintetében az 1-3 $\mu$ m-es tartomány a meghatározó. A membrándesztillációnál alkalmazott membránok pórus átmérője 0,1-1 $\mu \mathrm{m}$ között jellemző, így a cseppek nagyobbak, mint a pórusok, ami egy fontos kritérium az olaj-víz emulzió membrándesztillációval való szétválasztása során. Elméletileg az olajos fázis átjutásának a membrán pórusain három fó módja lehet:

- az emulzió átáramlik a pórusokon keresztül a pórusok nedvesedése során,

- a membrán felülethez ragadt olajcseppek áthaladása a membránpórusokon,

- a nyersolaj párolgása egyes komponenseinek.

GRYTA és KARAKULSKI (1999) munkája alapján a legfontosabb limitáló tényező egy olaj-víz emulzió szétválasztásánál a membrán nedvesedésének veszélye. A tanulmányban vizsgált 
modul kapillárcsöves volt, a membrán polipropilénből készült, a maximális pórusátmérő $0,62 \mu \mathrm{m}$ volt. Az olajkoncentrációt 0-2000 ppm közt volt változta. Az olajtartalom növelésével csökkent a desztillátum fluxus, és egészen 1000 ppm olaj koncentrációig nem jelentkezett olajszennyezés a desztillátumban. Magasabb olajkoncentráció esetében, 2000 ppm betáplálás mellett a desztillátumban 0,6 ppm olajtartalom volt mérhető.

Ezek alapján láthatjuk, hogy az elmúlt több mint 50 év alatt számos területet és lehetőséget vizsgáltak a különböző kutatók. Ezzel szemben, hogy az igazi ipari áttörést még nem sikerült elérni annak számos oka lehet. Munkám szemponjából kiemelném az utóbbiakban felmerült problémakört, miszerint is a membránok nedvesedése, ezáltal a desztillátum minőségének romlása egy elég nagy limitáló tényezőként ismert. Ezért tartottam fontosnak az LEP értékéhez körhető mérési módszerek alaposabb vizsgálatát, mivel a szakirodalom ennek elismert fontosságától függetlenül méltánytalanul keveset foglalkozik. Továbbfüzve a gondolatot, ha a pórusok nedvesednek, azok regenerálására lehetőség van, viszont ennek a hatékony megoldására sem történtek kifejezett, publikációban fellelhető törekvések, így hatékony megoldásukra tettem kísérletet jelen munkában. Olajos szennyvizek, olaj-víz emulziók szempontjából szintén kiemelten fontos a membrán korlátainak ismerete, e tekintetben sincs túl elérhető eredmény, így kutatásaimat az előzőek fényében, ebbe az irányba is szükségesnek láttam kiterjeszteni.

\subsection{Ozmotikus desztilláció}

Az ozmotikus desztilláció hajtóerejének nagyságát a membrán két oldalán áramló oldatok gőznyomásának, koncentrációjának különbsége, és a hőmérséklet lehetséges különbsége határozza meg. Ekkor a folyamatot membrán ozmotikus desztillációnak nevezzük (MOD), vagy elterjedt még az ozmotikus membrándesztilláció kifejezés is (OMD) (BÉLAFI-BAKÓ és KOROKNAI 2006; KOROKNAI et al. 2006). A hajtóerő létrehozására szolgáló oldatot ozmotikus oldatnak, vagy ozmotikus ágensnek nevezi a szakirodalom. Ez leggyakrabban valamilyen sóoldat, de egyéb, alacsony gőznyomással és viszonylag nagy felületi feszültséggel rendelkező $\left(>70 \mathrm{mNm}^{-2}\right)$ folyadék is megfelel. $\mathrm{Az}$ alkalmazott magas koncentrációjú sóoldatok legtöbbször $\mathrm{CaCl}_{2}, \mathrm{NaCl}, \mathrm{MgCl}_{2}$ sók vizes oldatai, de ritkábban fellelhetőek más sóoldatok alkalmazása is. Ezek az oldatok könnyen hozzáférhetőek és áruk is viszonylag kedvező. A szakirodalomban találhatunk elvétve példát olyan esetekre, ahol szerves anyagokat is, glikol, illetve glicerin oldatokat is vizsgáltak ozmotikus oldatként, ezek eredményeiről a következő fejezetekben írok részletesebben. 
A ozmotikus desztilláció művelete során az ozmotikus oldat folyamatosan hígul a membránon áthaladó víz hatására. Így a legnagyobb kihívás az ozmotikus desztilláció ipari méretben való alkalmazására a felhígult ozmotikus ágens regenerálása, gazdaságos és környezetkímélő módon. A bepárlás természetesen járható út, de akkor gyakorlatilag ugyanazt az energiát kell befektetnünk az elvont nedveség elpárologtatására, mint hogyha bepárolnánk, mindössze az alacsony hömérésékleten történő besűrítés előnyét tartottuk meg. Így a termék árának „el kell szenvednie“ a plusz membrános beruházási költségeket, mely eset csak különösen értékes és höérzékeny gyógyszeripari komponensek esetében lenne esetleg megvalósítható. A szakirodalmoban elvétve találunk különböző megoldásokat erre. Kujawski és mtsai (2009) pervaporációt alkalmaztak a kimerült ozmotikus oldat visszatöményítésére, viszont a magasabb fokú regenerálás szignifikánsan csökkenő fluxust eredményezett, így ennek alkalmazása nem túl bíztató.

Dolgozatomban olyan anyagokkal végzett kísérleteim eredményeit mutatom be, melyek ilyen, felhígult állapotban lehetnek értékesíthetőek az élelmiszeriparban, vagy a mezőgazdaságban. Mint nyilvánvaló, a müvelet hatékonyságának kulcsfontosságú eleme e megfelelö membrán mellett a megfelelő ozmotikus ágens kiválasztása. Összefoglalva a következő tulajdonságok a legfontosabbak:

- ne legyen mérgező,

- ne legyen korrozív,

- gyorsan, nagy koncentrációban oldódjon, alacsony gőznyomást eredményezve (12. ábra)

- kémiailag stabil maradjon,

- vizes oldata megfelelő felületi feszültséggel bírjon,

- alacsony viszkozitással rendelkezzen.

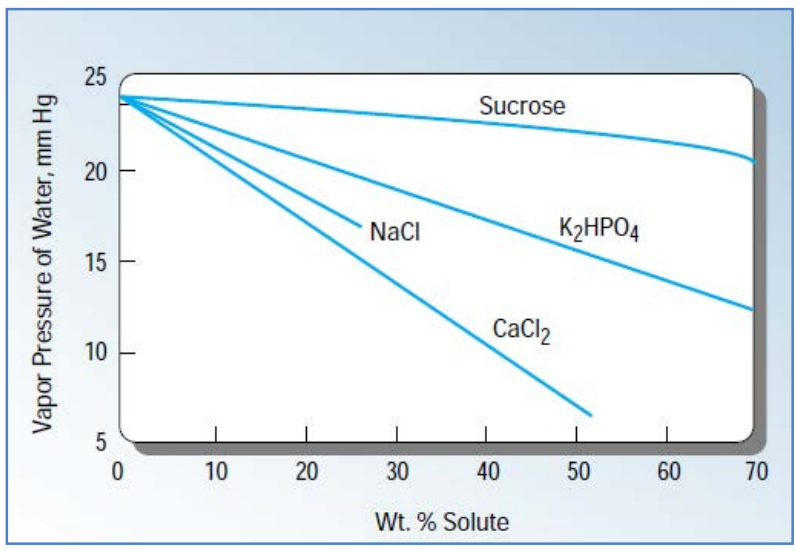

12. ábra Ozmotikus oldat vízgőznyomás-koncentráció diagramja (HOGAN et al. 1998) 


\subsection{1 Élelmiszer-adalékanyagok ozmotikus ágensként}

Az élelmiszerek megfelelő eltarthatósága, konzisztenciája és egyéb fontos tulajdonságai miatt gyakran elengedhetetlen bizonyos adalékanyagok használata. Ezeknek az adalékanyagoknak egy része szervetlen só, melyek a természetben szintén előfordulnak. Az ezekből előállított oldatok alkalmasak lehetnek az ozmotikus desztilláció müveletének elvégzésére és egyesek kedvezőbb tulajdonsággal bírhatnak, mint a jelenleg felhasznált anyagok. Akkor, ha ezek felhígulás után közvetlen felhasználhatóak valamilyen élelmiszeripari technológia esetében, illetve értékesíthetőek, elkerülhető az oldatok regenerálásának energiaköltsége. A következőekben olyan anyagokat mutatok be, melyek potenciálisan megfelelnek ezeknek a követelményeknek.

\subsubsection{Nátrium-klorid $(\mathrm{NaCl})$}

Tiszta állapotban nem higroszkópos, de szennyezett formája nedvszívóssá, tapadóssá válik. Kémiailag stabil vegyület, magas hömérséklet hatására sem bomlik el. Fontos szerepe van a szervezetben az izotónia, azaz a megfelelő ozmózis nyomás beállításához. Oldhatósága $30^{\circ} \mathrm{C}$-on mindössze 36,6 g/100g víz. erősen korrozív tulajdonságú. Ozmotikus ágensként manapság ritkán használják, mivel alacsony desztillátumfluxus érhető csak el vele, még telített állapotban is. Viszont a legegyszerübb és legolcsóbb a beszerzése, így ozmotikus hatékonyságát érdemes összehasnlítani.

\subsubsection{Kalcium-klorid $\left(\mathrm{CaCl}_{2}\right)$}

A kalcium-klorid szobahőmérsékleten szilárd sót alkot, vízben nagyon jól oldódik $\left(30^{\circ} \mathrm{C}\right.$-on $102 \mathrm{~g} / 100 \mathrm{~g}$ víz). Erősen higroszkopikus, ezért tárolásánál erre különösen ügyelni kell. Nagyon sokfelé használják az iparban és a mindennapi életben is, mind például utak sózására, jégtelenítésre. Élelmiszeriparban a $\mathrm{NaCl}$ kiváltására használják sajtfélék, paradicsomsürítmények, és konzerv zöldségek sózására (E509). Azonban kiváló ozmotikus tulajdonságai miatt, és mivel nagy mennyiségben, olcsón elő́llítható, az ozmotikus desztilláció egyik leggyakrabban használatos oldata. A számos publikáció közül példaként említeném ananászlé, és nonilé besürítését $\mathrm{CaCl}_{2}$ ozmotikus oldat segítségével (HONGVALEERAT et al. 2008; VALDÉS et al. 2009). Hátránya, hogy erősen korrodáló hatása van, a fém alkatrészeket hamar megtámadja, különösen nagy koncentráció tartományban.

\subsubsection{Nátrium-nitrát $\left(\mathrm{NaNO}_{3}\right)$, kálium-nitrát $\left(\mathrm{KNO}_{3}\right)$}

A nátrium-nitrát (E251) és kálium-nitrát (E252) a talaj természetes összetevői, ezért változó mennyiségben, de elöfordulhatnak minden növényi élelmiszerben. A nátrium-nitrát oldhatósága 96 g/100 g víz, a kálium-nitrát oldhatósága 45,8 g/100 g víz. Élelmiszeradalékként a baktériumok, különösen a botulizmust elöidéző Clostridium botulinum ellen alkalmazzák. A hatóanyag viszont nem 
a nitrát, hanem a nitrit, amely a nitrát mikrobiológiai átalakulása nyomán képződik. Ez a folyamat ellenőrizhetetlenül zajlik le, ezért a nátrium-nitrátos pác-sót csak száraz pácokhoz javasolt használni. A nátrium-nitrát, mint a pác-só összetevője húskészítményeknél, kemény- és félkeménysajtoknál, pácolt hering és ruszli termékeknél engedélyezett. Ozmotikus ágensként ígéretesnek tủnnek, mivel felhígulva, pác-sóként közvetlen felhasználható a fent megemlített élelmiszerek előállítása során.

\subsubsection{Kálium-acetát $\left(\mathrm{CH}_{3} \mathrm{COOK}\right)$}

A kálium-acetát egy kálium tartalmú bázis és ecetsav reakciójából keletkező szerves só. Oldhatósága $30^{\circ} \mathrm{C}$-on $283,8 \mathrm{~g} / 100 \mathrm{~g}$ víz. Kloridok helyett jégtelenítésre, síkosság mentesítésére használják. Élelmiszerekben tartósítószerként, valamint savanyúságot szabályozó anyagként alkalmazzák (E261) mivel lágyítják a túl erősen savanyú ízhatást. Az élelmiszeriparban az acetátok gondoskodnak a kocsonyák, az ömlesztősók és a húsaprításhoz szükséges segédanyagok (kuttersegédanyagok) megfelelő savfokáról. Ozmotikus ágensként kevésbé korrodál, mint a $\mathrm{CaCl}_{2}$ és $\mathrm{NaCl}$, ezt SHIN és JOHNSON (2007) korrózióvizsgálattal bizonyította. Kísérleteik során jól kivehető, hogy a legnagyobb desztillátumfluxust ezzel az oldattal érték el. Magas oldhatósága miatt ez ígérkezik a leghatékonyabbnak.

\subsubsection{Kálium-karbonát $\left(\mathrm{K}_{2} \mathrm{CO}_{3}\right)$}

A kálium-karbonátok (hamuzsír) (E 501 i) sav hatására lebomlanak, miközben szén-dioxid szabadul fel. Ennek a jelenségnek hatására tudják megnövelni például a tészták térfogatát, lazábbá téve állományukat. A péksütemények barnulását is elősegíthetik.

A kálium-karbonátokat kémiai úton szén-dioxidból (E 290) és kálilúgból állítják elö. A káliumkarbonátok az élelmiszerekben mennyiségi korlátozás nélkül, általánosan engedélyezettek. Ez alól csupán a kezeletlen és hasonló élelmiszerek a kivételek, amelyek a törvényalkotó szándéka szerint adalékanyagokkal nem módosíthatók. Többek között sütőporok, csokoládé- és kakaókészítmények, kakaó- és kávéhelyettesítő termékek adalékanyagaként használja az élelmiszeripar. A kálium-karbonátot ezenkívül konyhasó-helyettesítőként, valamint a fehérjék és a kakaó feltárására is használják. Gyakori felhasználása miatt értékesítése szintén ígéretesnek tünik, ezzel jó alapot adva az ozmotikus ágensként való felhasználásra.

\subsubsection{Mütrágya alapanyagok ozmotikus ágensként}

A mütrágyaként felhasználható, jó oldhatóságú szervetlen sók az ozmotikus desztillációs müvelet elvégzése után visszahígítás nélkül kivihetőek a szántóföldekre, vagy értékesíthetőek. Ezek 
élelmiszeripari alkalmazása vitatott, de egyéb, nem élelmiszeripari koncentrációs feladatok elvégzése szempontjából vizsgálatuk érdekes lehet.

\subsubsection{Kalcium-nitrát $\left(\mathrm{Ca}\left(\mathrm{NO}_{3}\right)_{2}\right)$}

A növények a kalcium-nitrátot leginkább a vegetatív növekedés idején, azaz a fő levéltömegek kifejlődésekor igénylik. A későbbiekben a megfelelő nitrogén ellátás a tároló részekben (mint a magvakban, hagymákban és termésekben) megnövekedett fehérje szintézis miatt szükséges. Különösen szikes talajokon használható jól.

\subsubsection{Ammónium-nitrát $\left(\mathrm{NH}_{4} \mathrm{NO}_{3}\right)$}

Az ammónium-nitrát egy szervetlen só, erősen higroszkópos vegyület. Normál körülmények közt 10 mól kristályvizet tartalmaz. Vízben jól oldódik. Vízben való oldása endoterm, erős hülés tapasztalható. Magasabb hőmérsékleten, vízmentes állapotban erős oxidálószer. Műtrágyának és robbanószerek készítésére használják. Magas nitrogéntartalma miatt mütrágyagyártásra használják. Ozmotikus oldatként való alkalmazása speciális körültekintést igényel, de folyamatos, endoterm oldása növelheti a hőmérséklet-különbséget, ezzel a desztillátumfluxus értékét.

\subsubsection{Ammónium-szulfát (( $\left.\left.\mathrm{NH}_{4}\right)_{2} \mathrm{SO}_{4}\right)$}

Az ammónium-szulfát egy szervetlen vegyület, melyet elsősorban lúgos kémhatású talajok mütrágyaként alkalmaznak. A talajba kerülve kénsav szabadul fel, mely csökkenti a talaj pH-értékét, valamint a növények növekedéséhez nélkülözhetetlen nitrogén is jut a talajba.

- A mezőgazdaságban elősegíti a különféle gombaölö, rovarirtó- és gyomirtó-szerek müködését.

- A különféle ammóniatartalmú vegyületek szintézisekor is alkalmazzák.

- A biokémiában az ammónium-szulfátot a fehérjék tisztítására is használják.

- Számos gyógyszerben megtalálható.

Az élelmiszeriparban elsősorban stabilizálószerként, pufferanyagként, valamint térfogatnövelöként alkalmazzák (E 517). Elsősorban pékárukban, és cukrászipari termékekben fordul elő. Az ammóniumszulfátok kizárólag más adalékanyagok hordozóanyagaként engedélyezettek. A bor és a gyümölcsbor előállítása során az élesztők tápanyagaként szolgálnak.

\subsubsection{Egyéb ozmotikus ágensek}

A fentiekben kiemelt ozmotikus ágenseken kívül is van még számos alternatív megoldás a tömény sóoldatra. Sok esetben jobb e sók oldhatósága, de élelmiszeripari szempontból nem 
alkalmazhatók biztonságtechnikai okok miatt (JIAO et al., 2004). CELERE és GOSTOLI (2004; 2005) például propilén-glikol, glicerin és glicerin-só alkalmazását hasonlították össze a $\mathrm{CaCl}_{2}$ oldattal. Számos paramétert vizsgáltak (oldhatóság, viszkozitás, hajtóerő, desztillátum fluxus, membrán behatási nyomás) és arra a következtetésre jutottak, hogy bár a glicerinnel és propilén-glikollal hasonló fluxust tudtak elérni, alkalmazásukat mégsem ajánlott a $\mathrm{CaCl}_{2}$-hoz képest nagyobb viszkozitás értékük és élelmiszerbiztonsági szempontok miatt. A propilén-glikol alacsony penetrációs nyomása miatt áthaladt a membránon a desztillátum oldalra, a glicerinnek pedig magas viszkozitás értékeket mértek, ami negatívan hatott a folyamatra. A propilén-glikol szintén használatos az élelmiszeriparban, hordozószerként. A propilén-glikol kizárólag a következő alkalmazásokra engedélyezett, rágógumi (mennyiségi korlátozás nélkül), aromák (max. $1 \mathrm{~g} / 1)$. Oldószerként és nedvesítőszerként a propilénglikolt többek között kozmetikumokban és dohánytermékekben is alkalmazzák.

\subsection{Többlépcsős membrános eljárás hatóanyagok kinyerésére}

A zsálya a legnagyobb nemzetség az árvacsalánfélék családjában, közel 900 faj tartozik ide (DELAMARE et al., 2007). A zsálya ősidők óta ismert gyógynövény, több mint hatvanféle szimptómának a kezelésére használják, különböző fájdalmak enyhítésére, megfázás ellen, hörghurutos megbetegedések kezelésére, tüdőbaj, valamint menstruácós problémák enyhítésére egyaránt (TOPCU 2006). A Salvia fruticosa Miller (vagy Salvia triloba L.), más néven görög zsálya egy kiemelkedően fontos növény a zsályanemzetségben, amely a mediterrán térségben őshonos. Törökország az egyik vezető ország a görög zsálya feldolgozását és exportját tekintve (1544 tonna 2009-ben) (DINCER et al. 2012). A görög zsálya számottevő bioaktív molekulát tartalmaz, mint például a polifenolok, terpének, melyek gyulladáscsökkentő (EL-SAYED et al. 2006), antimikrobiális (DELAMARE et al., 2007) és antioxidáns (TEPE et al. 2006) hatással rendelkeznek. Hagyományosan a zsálya leveleit 3-5 perces extrakcióval, forrázatként gyógytea formájában fogyasztják. Manapság értékesítik hagyományos teafilteres formában, de ez igazán nem praktikus a nem megfelelő extakciós idő, és a viszonylag kis kihasználatlanság miatt. A zsályakivonatot oldható por formában, instant oldható gyógyteaként, illetve gyógykészítmény formájában értékesítve nagyobb értékes komponens kinyerés valósítható meg, így ebben a formában való értlkesítése is egyre inkább előtérbe kerül.

Az instant italok előállítása általában a következő részfolyamatokból tevődik össze: extrakció, aromakinyerés, koncentrálás, és végül porlasztva szárítás (VINCZE et al. 2007). A szárítási kihozatal növelése céljából a porlasztva szárítási lépés előtt az előkoncentrálást $20-40 \mathrm{~m} / \mathrm{m} \%$-ig szokás elvégezni, a kisebb elpárologtandó nedvesség miatt. Ez a koncentrálási müvelet hagyományosan 
valamilyen bepárlási technikával kerül megvalósításra, annak ellenére, hogy közismert tény, hogy az értékes, bioktív komponensek károsodást szenvednek magas hőmérsékleten, így a termék veszít egészségmegőrző hatásából.

Alternatív megoldás lehet erre a folyamatra a membrántechnológia alkalmazása, vagy a kifagyasztásos technika. A hagyományos kifagyasztásos technikák felhasználásával elkerülhető az értékes anyagok mennyiségének jelentős csökkenése, viszont jelentős energiabefetetést igényel, az eljárás költséges. A membrántechnológiák alkalmasak folyékony élelmiszerek koncentrálására jelentős bioaktív komponens csökkenés nélkül. Általában ezek a müveletek szobahőmérsékleten véghezvihetőek $\left(20-25^{\circ} \mathrm{C}\right)$, mely csökkenti a hődegradáció mértékét. Ezek a kapcsolt, vagy más néven integrált membrános műveletek legalább két-három műveleti lépést jelentenek. Általában először egy tükrösítési, illetve hideg csírátlanítási mikroszürő, vagy ultraszürő müvelet az első egység. Ezt követően egy elö-koncentrálási lépés történik fordított ozmózissal, vagy nanoszüréssel, mellyel a kiindulási oldat koncentrációja 20-25 mm ozmotikus desztillációs, vagy membrándesztillációs eljárással lehet a végső $35-70 \mathrm{~mm}^{-1} \%$-ot elérni, mely koncentrációérték gátolja a mikrobák elszaporodását, így a sürítmény egyéb tartósítószerek hozzáadása nélkül is eltartható.

Ezeket a többlépcsős membrános müveletek gyümölcslé sürítmények előálítására már több ízben is megvizsgálták, mint például kiwilé (CASSANO et al. 2004; 2006) camu-camu gyümölcslé (RODRIGUES et al. 2004), szőlőlé (REKTOR et al., 2006), almalé (ÁLVAREZ et al. 2000), citrusgyümölcslé (CASSANO et al., 2003) koncentrálására, vagy fekete ribizlilé koncentrálására (KOZÁK et al. 2008; 2009), de gyógynövény extraktumok, drogextraktumok koncentrálására ozmotikus desztillációs végkocentrációval példát a szakirodalomban nem találtam. Találunk példát viszont membrándesztilláció alkalmazására ginseng-kivonat (ZHAO et al. 2008; 2011) koncentrálására, habár ezek a vizsgálatok a inkább müveleti hatékonyságra, és nem a bioaktív komponensek megóvására fókuszáltak. Ilyen tekintetben munkám hiánypótlónak tekinthető, mely bár szorosan illeszkedik a már gyümölcslére elvégzett kapcsolt müveletekhez, mégis új eredménynek tekinthető.

\subsection{A meggy és annak egészségmegőrző tulajdonságai}

A meggy egy nagyon jellemző gyümölcs Európában, de egyaránt az egész világon. A meggy (Prunus Cerasus) polifenolokat tartalmaz, antioxidáns és gyulladáscsökkentő hatással bír, és a belőle nyert lé elfogyasztásával kiválóan tudjuk kezelni izomfájdalmainkat, alvászavarunkat, és általános egészségünket. Magas antioxidáns kapacitása ennek egyik jellemző bizonyítéka. Legjellemzőbb fajtái 
Magyarországon a Korai Pipacs, az Érdi bőtermő, az Oblacsinszka, az Újfehértói fürtös, Pipacs 1, Balaton, de még számos fajta létezik. Antioxidáns kapacitásuk FRAP módszer alapján mérve a 2-25 mmol aszkorbinsav egyenérték literenként. Kiemelkedően magas az Pipacs I, melynek $23 \mathrm{mmol}$ aszkorbinsav egyenérték literenként a FRAP értéke.

Egyik fontos antioxidáns hatású molekulacsoport a flavonoidok csoportába tartozó antocianinok, melyek olyan vízoldható színanyagok, melyek a pH függvényében különböző színủek lehetnek: vörös, bíbor, vagy kék. Az antocianinok nemcsak színanyagok, hanem fontos alkotóik lehetnek egy egészséges diétának. A meggynek gyulladáscsökkentő hatása is van, csökkenti a duzzanatokat, gyulladást és az oxidatív stresszt. További fontos egészségvédő hatás a meggy antocianinjainak gyulladáscsökkentő hatása reumás, köszvényes megbetegedések esetén (WANG et al. 2005). Azt is fontos megjegyezni, hogy a meggy antocianinjainak gátló hatása van a COX-1 és COX-2 enzimekre, melyek a gyulladást erősítik (SEERAM et al. 2001). Továbbá KANG és mtsai (2003) megállapították, hogy a meggy védelmet nyújthat a bélrendszer daganatos megbetegedése ellen.

Az elmúlt években számos tanulmány született az antocianinokról és erős antioxidáns kapacitásukról, lehetőségükről a kemoterápiában. Szintén hatásosnak bizonyult a „kettes típusú“ diabétesz ellen, növelve az inzulin kiválasztást (JAYAPRAKASAM et al. 2005). Egyes fajták, mint például a Montmorency és Balaton melatonint is tartalmaz, mely egy fontos hormon az alvási ciklusok kialakításásban , valamint erős antioxidáns hatással is bír. A vitaminok közül A-vitamin és C-vitamin a jellemző, melyet a meggy tartalmaz, ez szintén növeli az egészségmegőrző hatást.

Ezek alapján látható, hogy a meggy és az abból préseléssel készült meggy olyan termékek, melyeknek minőségét érdemes megőrizni, és erre korszerủ és hatékony folyamatokat kidolgozni. 


\section{A MEGOLDANDÓ FELADATOK ISMERTETÉSE}

\subsection{A membránpórus-nedvesedés jelenségének vizsgálta membrándesztilláció esetén}

A membrándesztillációs vizsgálataim első része a müvelet egyik alapvető paraméterének, a folyadék behatolási nyomásnak $\left(\mathrm{LEP}_{\mathrm{w}}\right)$ a meghatározásával foglalkozik. Abban az esetben, ha a membránpórusok már nedvesedtek, csak egy regenerálási eljárás elvégzése után lehetséges további membrándesztillációs müveletek elvégzése. Ez gyakorlatilag a nedvesség teljes eltávolítását jelenti a pórusokból, amit általában csak a membrán berendezésből való elávolítása után lehet megfelelően elvégezni. A szakirodalomban gyakorlatilag nem lehet fellelni olyan publikációt, ami teljes egészében erre a problémakörre fókuszálna, illetve alternatívát nyújtana a gyors és hatékony regenerálási eljárásra.

\section{Kapcsolódó feladatok pontokba szedve a következőek:}

- Kísérleti berendezés összeállítása és az $\mathrm{LEP}_{\mathrm{w}}$ mérése a szakirodalom alapján - statikus módszer,

- DCMD és VMD kísérleti berendezések összeállítása az új, dinamikus LEP ${ }_{\mathrm{w}}$ mérési módszerek tesztelésére, hiszterézisgörbe kimérése,

- Regenerálási kísérletek: magas hőmérsékletű és vákuummal törénő szárítás a membránpórusok nedvesedését követően.

\subsection{Olaj-víz emulzió szétválasztása vákuum-membrándesztilláció segítségével}

Ha a betáplált oldatunk valamilyen felületaktív anyagot, illetve szerves fázist tartalmaz, az LEP értéke drasztikusan csökkenhet. A vizsgálataim során alacsony koncentrációjú model olaj-a-vízben $(\mathrm{O} / \mathrm{V})$ emulzió szétválasztását valósítottam meg vákuum-membrándesztillációval.

\section{Kapcsolódó feladatok pontokba szedve a következőek:}

- LEP érték változásának vizsgálata a model O/V emulzió összetételének függvényében, állandó hőmérsékleten, statikus és dinamikus módszerrel,

- O/V emulzió szétválasztásának vizsgálata vákuum-membrándesztillációs berendezéssel,

- A müvelet hatékonysága, az előállított desztillátum minőségének analitikai elemzése. 


\subsection{Többlépcsős membrános eljárás zsályahatóanyagok kinyerésére}

A membrándesztilláció egyik megvalósítási módjának, az ún. ozmotikus desztillációnak az élelmiszeripari alkalmazása egy jelentős kutatási terület. A müvelet alacsony hőmérsékleten való elvégzésének lehetősége miatt folyamatosan a kutatások tárgyát képezi. Az élelmiszeripari alkalmazások mellet elvétve találunk kifejezetten gyógynövénykivonatok koncentrálására összpontosító kutatásokat.

A zsályafélék családjának sok tagja ismert gyógy-és füszernövény, magas antioxidáns tartalommal bírnak, fogyasztják gyógyteaként, de egyéb gyógyhatású készítményként egyaránt. Az egészségre jótékony hatásának a megörzése céljából egy új, kíméletes és hatékony tartósítási módszer kidolgozására törekedtem.

\section{Kapcsolódó feladatok pontokba szedve a következőek:}

- Folyadékfázisú extrakum kinyerése a szárított görög zsálya (Salvia Fruticosa Miller) gyógynövény leveleiből,

- Az elkészített extraktum előszürése mikroszüréssel, a mikroszürés kritikus és limitáló paramétereinek megállapítása a desztillátum fluxus és a transzmembrán nyomáskülönbség tekintetében,

- Az előszürt extraktum elősürítése fordított ozmózissal, a kritikus paraméterek megállapítása,

- Az elkészített elősürítmény végsürítése ozmotikus desztillációval,

- A kiindulási extraktum és a termékek összes flavonoid, összes polifenol és antioxidáns kapacitás változásának nyomon követése spektrofotometriás eljárásokkal, valamint a jellemző polifenolok vizsgálata nagy teljesítményü folyadékkromatográfiás analitikai módszerrel.

\subsection{Meggysűrítmény előállítása kapcsolt membrános müvelettel, új ozmotikus oldatokkal}

Meggy préselése során kinyert meggylé koncentrálását valósítottam meg többlépcsős membrán müvelettel. Vásznon történő elöszürés után a meggylevet mikorszüréssel tükrösítettem és hidegen csírátlanítottam, majd pedig két fajta fordított ozmózisos eljárással elősürítettem. Az így kapott elősürített meggylevet négy különböző szervetlen sóból előállított ozmotikus oldattal sürítettem végkoncentrációig. Külön fejezetben vizsáltam a leghatékonyabbnak bizonyult ozmotikus oldat müveleti jellemzőit a desztillátum fluxusra. 


\section{Kapcsolódó feladatok pontokba szedve a következőek:}

- Új ozmotikus oldatok hatékonyságának vizsgálata desztillált vízfluxusra vonatkoztatva,

- A leghatékonyabb ozmotikus oldat felhasználásával, $2^{\mathrm{p}}$ teljes faktoros analízissel vizsgáltam a kiindulási koncentráció, a beteáplálás hőmérsékletének, és a hőmérésklet különbségnek a szerepét a desztillátum fluxusra,

- Meggylé mikroszürése, a mikroszürés ellenállásainak meghatározása,

- Elősürítés két fordított ozmózisos konfiguráció végrehajtásával,

- Végsürítés négyfajta ozmotikus oldat segítségével,

- A leghatékonyabb ozmotikus oldat anyagátadási jelenségeinek vizsgálata,

- Analitikai vizsgálatok az értékes anyagok vizsgálatára, statisztikai módszerekkel igazolva. 


\section{ANYAg ÉS MÓDSZER}

\subsection{A membránpórus-nedvesedés jelelenségéhez kapcsolódó kísérleti módszerek}

Membrán desztilláció során a hidrofób membrán pórusainak nedvesedése nem kívánt, sőt, kifejezetten kerülendő jelenség, így az $\mathrm{LEP}_{\mathrm{w}}$ értékének pontos ismerete a müveleti tervezés során kulcsfontosságú. Ebben az alfejezetben az LEP $_{\mathrm{w}}$ értékének kísérleti meghatározásához szükséges módszereket kívánom bemutatni. Az alfejezet második részében a már nedvesedett membránok regenerálásának módjait fejtem ki.

\subsubsection{Kísérleti berendezés összeállítása és az $\operatorname{LEP}_{\mathrm{w}}$ mérése - statikus módszer}

Durapore $^{\mathrm{TM}}$ GVPH lapmembrán (Merck Millipore Inc., Billerica, USA) LEP ${ }_{\mathrm{w}}$ értékét határoztam meg SMOLDER és FRANKEN (1989) alapján. A membrán polivinilidén-fluoridból készült (PVDF), névleges pórusmérete 0,22 $\mu \mathrm{m}$ és a hasznos membrán felület $0,00444 \mathrm{~m}^{2}$ volt. Egy szendvicsmodulban elhelyezve vizsgáltam. A méréseket szobahőmérsékleten végeztem el $\left(25^{\circ} \mathrm{C}\right)$. A szendvicsmodul elemeit és a vizsgált lapmembránt az 13. ábra szemlélteti.
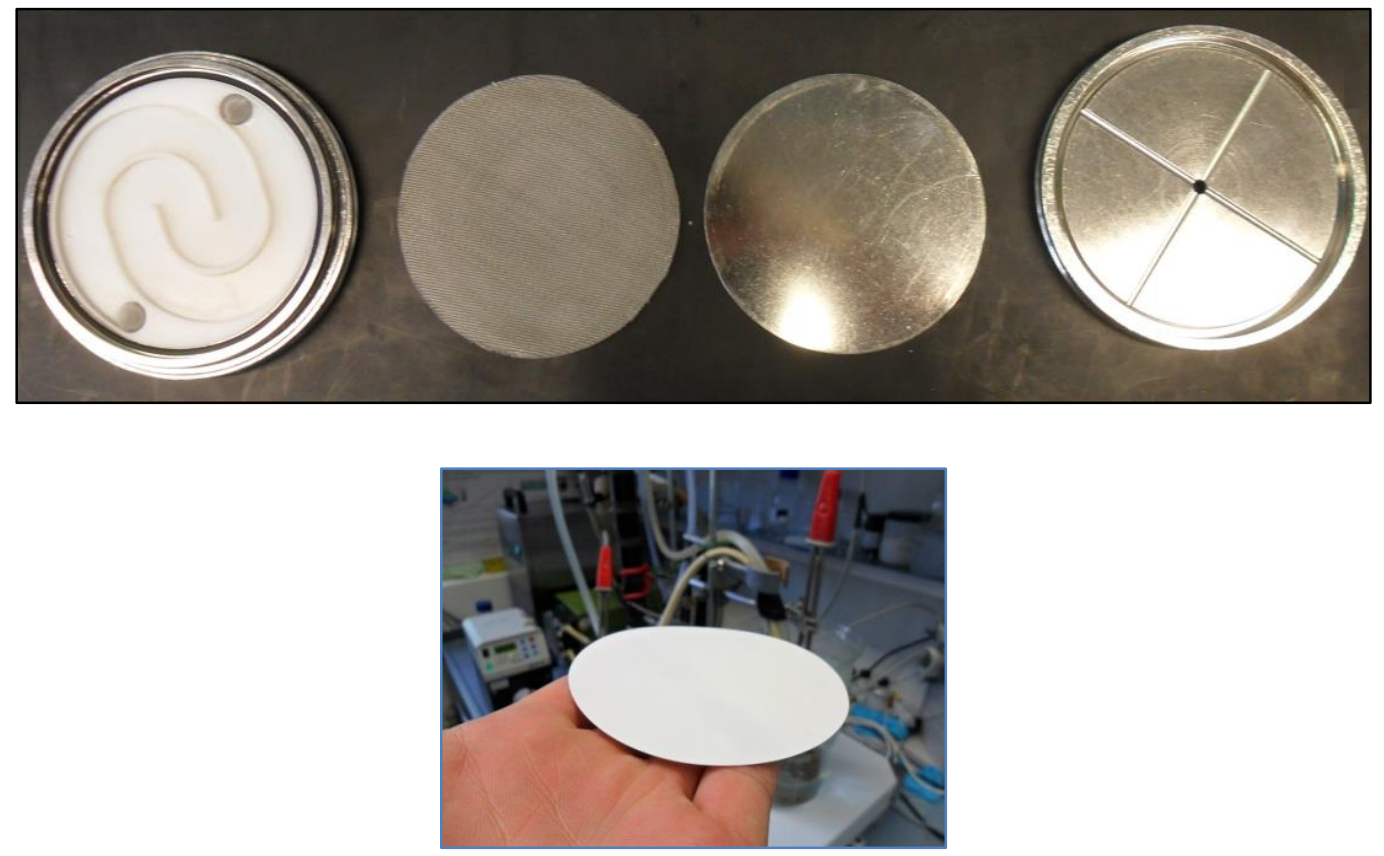

13. ábra Szendvics modul fent (betáplálási áramlási csatorna, támasztó réteg, merevítő lemez, permeátum oldali gyüjtő ház) és a vizsgált lapmembrán (Durapore ${ }^{\mathrm{TM}} \mathrm{GVPH}$ ) LEP lent $_{\mathrm{w}}$

Az LEP $_{\mathrm{w}}$ meghatározása az 14. ábrán látható laboratóriumi berendezésen valósult meg. Három párhuzamos mérést végeztem, minden mérésehez új membránt használtam. A modul felső részét (betáplálás oldal) feltöltöttem desztillált vízzel, mely így közvetlenül érintkezett a modulban elhelyezett 
hidrofób membrán felső felületével. A feltöltést követően a felső rész kilépő csonkját elzártam, ezáltal egy mozdulatlan desztillált víz réteg alakult ki a membrán felső érintkezési felületén, viszont a kapilláris erök miatt pórusait nem nedvesíthette. A desztillátum oldali folyadék elvezető csövet egy, a modul alatt elhelyezett, vízzel feltöltött edénybe vezettem, hogy a nedvesedés után a mozgó folyadékszint által a modulból kipréselt levegő megjelenését láthatóvá tegyem buborékok formájában.

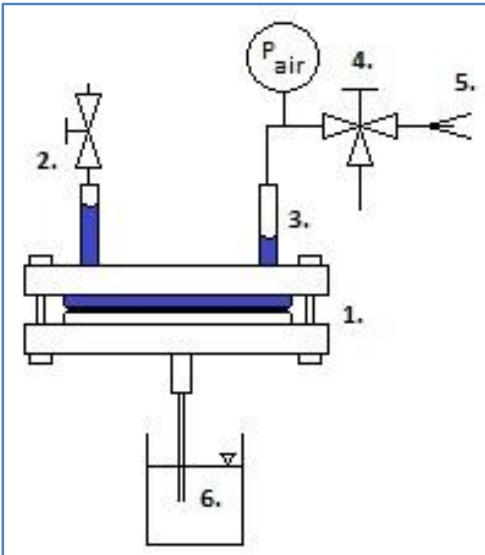

a.)

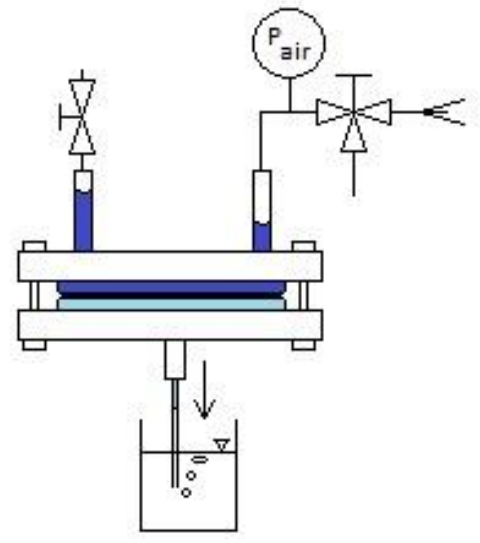

b.)

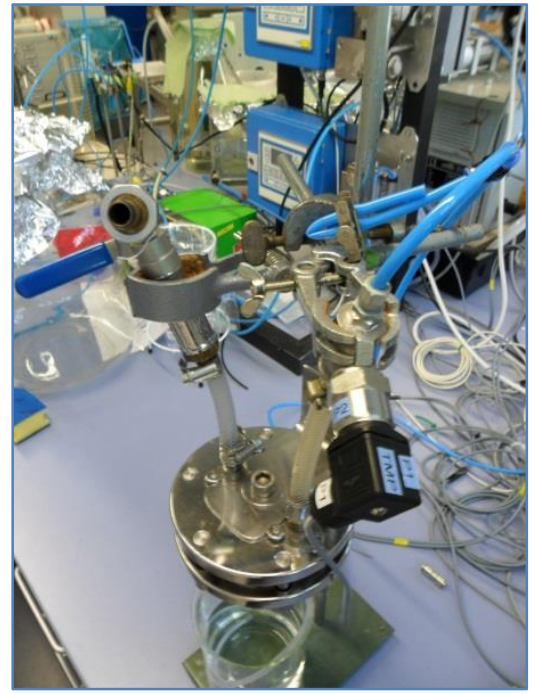

14. ábra Lapmembrán (Durapore $\left.{ }^{\mathrm{TM}} \mathrm{GVPH}\right) \mathrm{LEP}_{\mathrm{w}}$ értékének meghatározása statikus módszerrel a.) nedvesedés előtt, b.) LEP $\mathrm{w}_{\mathrm{w}}$ pillanatában (1. szendvics modul lapmembránnal, 2. elzáró csap, 3. a membrán betáplálási oldala desztillált vízzel feltötlve, 4. sűrített levegő-szabályozó, 5. sűrített levegő belépése, 6 . edény vízzel feltöltve)

Először, a 14. a) ábrán megfigyelhető módon, sürített levegőt alkalmazva állandó, 0,2 bar túlnyomást fejtettem ki a betáplált vízrétegre, 10 percig. A nyomás aktuális értékét egy nyomásmérő érzékelő (Wika GmbH, Németország) segítségével követtem nyomon, ami egy LAb-manager (HiTech Zang GmbH, Németország) interfészhez volt csatalakoztatva. Ha ez alatt az idő alatt nedvesedés nem történt meg, 5 percenként 0,10 bar-ral növeltem a sürített levegővel a betáplálás oldali nyomást - így a transzmembrán hidrosztatikai nyomáskülönbséget - egészen addig, míg a desztillált víz a betáplálás oldalról el nem kezdett behatolni a pórusokba, legyőzve a membránpórusok kapilláris erőit. Ekkor a modul alatt elhelyezett, vízzel feltöltött edényben elöször buborékok jelentek meg, majd egy mozgó meniszkuszt lehetett megfigyeli a membrán desztillátum elvezető csövében (14. b.) ábra). A buborékok megjelenésének pillanatában fenálló nyomáskölönbséget tekintettem a membrán LEP ${ }_{\mathrm{w}}$ értékének. 


\subsubsection{Kísérleti berendezés összeállítása és az LEP $P_{w}$ mérése - dinamikus módszer}

\subsubsection{DCMD elrendezés felépítése és $\operatorname{az} \operatorname{LEP}_{\mathrm{w}}$ mérése}

Az általam kidolgozott új, dinamikus módszerrel MD 020 CP 2N csöves modul (Microdyn-Nadir $\mathrm{GmbH}$, Wiesbaden, Németország) LEP ${ }_{\mathrm{w}}$ értékét határoztam meg, DCMD elrendezésben. Ez a modul 40 db hidrofób polipropilén (PP) csőmembránt tartalmazott, melyek belső átmérője egyenként 1,8 mm, külső átmérője 2,6 mm, hossza $500 \mathrm{~mm}$, a membrán átlagos pórusmérete $0,2 \mu \mathrm{m}$ és az összes, hasznos membránfelület $0,1 \mathrm{~m}^{2}$ volt. A vizsgálatokat $25^{\circ} \mathrm{C}$-on végeztem el. Mind a betáplálási, mind a desztillátum oldalon lamináris áramlási körülményeket biztosítottam. A betáplálás és a desztillátum oldali közegek egyenáramban áramoltak - a betáplálás a csövek belsejében, a desztillátum a köpenyoldalon. Mindkét közeg térfogatárama $36 \mathrm{Lh}^{-1}$ volt, ezáltal a betáplálás oldalon $\mathrm{Re}_{\text {betáp }}=200$, és a desztillátum oldalon pedig $\operatorname{Re}_{\text {deszt }}=170$ adódott. A vizsgálatok a 15. és 16. ábrákon bemutatott laboratóriumi berendezésen végeztem el.

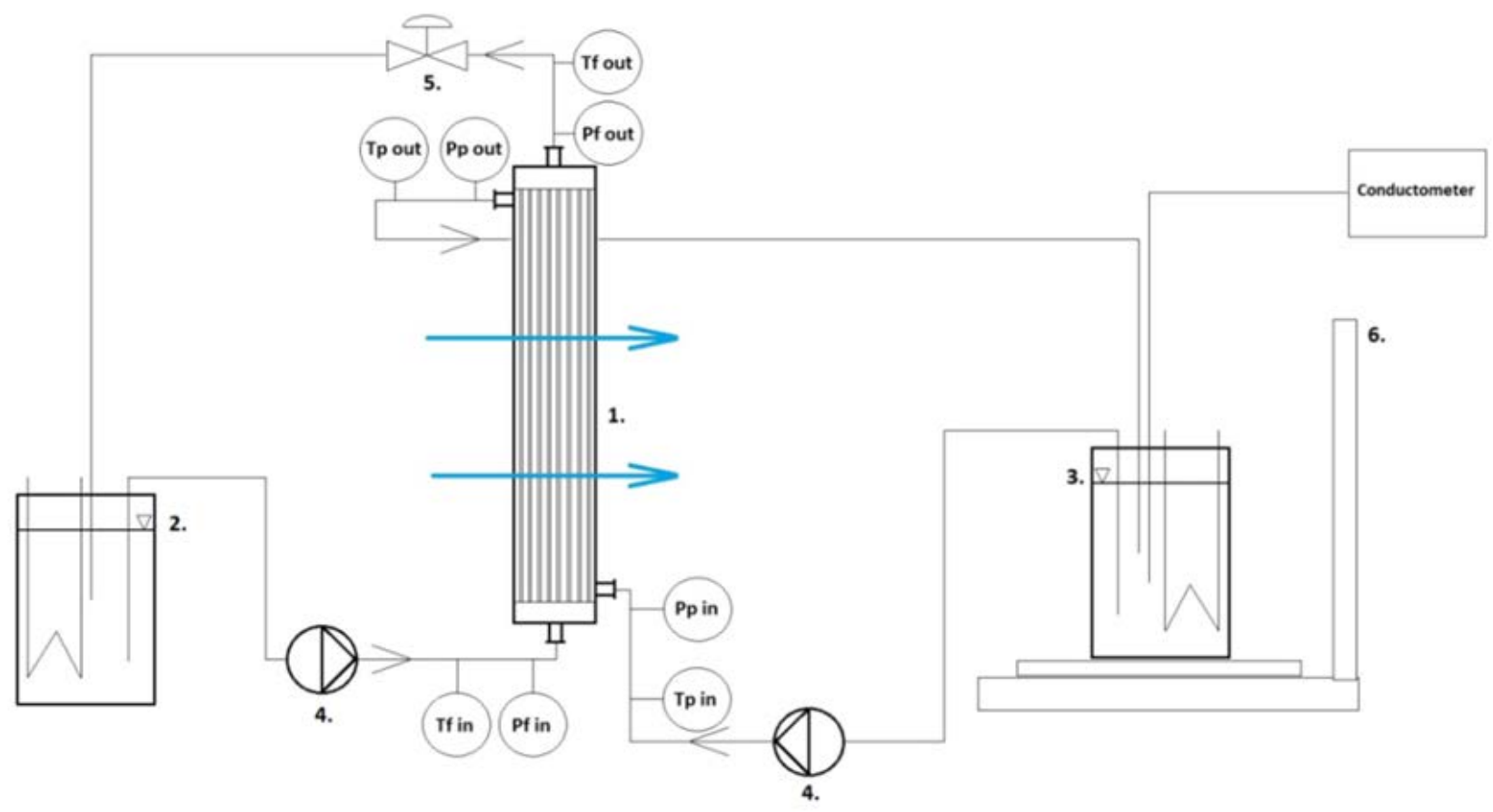

15. ábra Csöves membrán modul (MD 020 CP 2N) LEP ${ }_{w}$ értékének meghatározása dinamikus módszerrel, DCMD elrendezésben (1. csöves membrán modul, 2. betáplálás, 3. desztillátum gyüjtő edény, 4. laborszivattyú, 5. nyomásszabályozó, 6. digitális mérleg) 


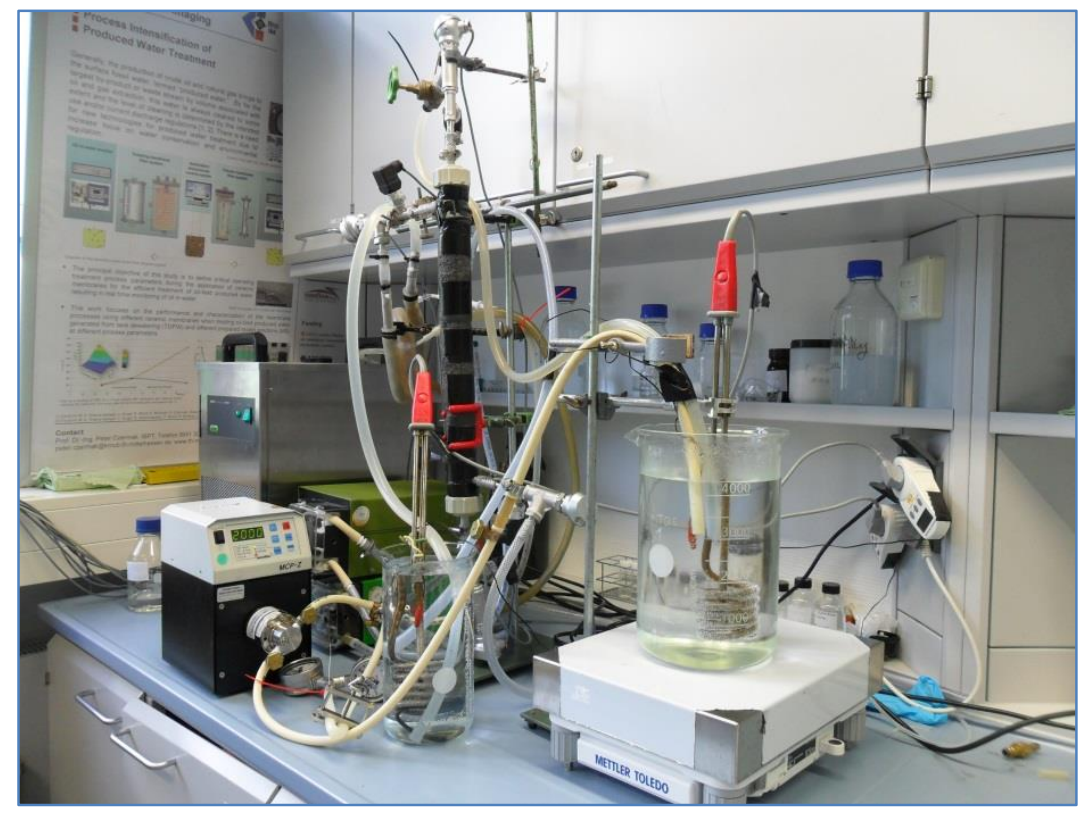

16. ábra Csöves membrán modul (MD 020 CP 2N) LEP ${ }_{w}$ értékének meghatározása dinamikus módszerrel, DCMD elrendezésben

Az LEP $_{\mathrm{w}}$ értékének megállapításához a betáplálás oldali nyomást lépcsőzetesen növeltem egy nyomásszabályozó szelep segítségével, manuálisan. A betáplálás $0,36 \mathrm{mScm}^{-1}$ vezetőképeségü sóoldat volt $\left(24,7^{\circ} \mathrm{C}\right)$ (Hanna HI 99301 EC meter, Hanna instruments, Woonsocket, Rhode Island, USA), a nedvesedés pillanatának pontosabb meghatározásához. Feltételeztem, hogy ez az alacsony sótartalom nem okoz szignifikáns változást $\mathrm{az} \mathrm{LEP}_{\mathrm{w}}$ értékében, mivel ez a felületi feszültség értékében kevesebb, mint 5\%-os eltérést ererményez. A DCMD elrendezés desztillátum oldalán desztillált vizet áramoltattam kevesebb, mint $0,01 \mathrm{mScm}^{-1}$ vezetőképeséggel $\left(25,1^{\circ} \mathrm{C}\right.$ ) (a Hanna HI $99301 \mathrm{EC}$ meter müszer kimutathatósági értéke alatt). A szürletfluxus, és ezen keresztül a hiszterézis megállapításához digitális mérleget használtam (Mettler-Toledo, Svájc), mely rögzítette a desztillátum tömegét az idő függvényében. A hőmérséklet és nyomások mérése érzékelők segítségével történt (Wika GmbH, Németország). Mind a digitális mérleg, mind pedig az érzékelők egy Lab-mananger (HiTech Zang $\mathrm{GmbH}$, Németország) interfészhez voltak kapcsolva, amely LabVision (HiTech Zang GmbH, Németország) szofter segítségével rögzítette az érzékelök jeleit az idő függvényében. Ezek alapján számítottam az $\mathrm{LEP}_{\mathrm{w}}$ pontos értékét majd pedig ábrázoltam a hiszterézisgörbét. Az edények a párolgási veszteség minimalizálása végett lefedtem a kísérletek alatt.

A vizsgálat maga két részletben folyt le: először az $\mathrm{LEP}_{\mathrm{w}}$ meghatározása történt, majd pedig a már nedvesedett membrán hiszterézisének kimérése zajlott le. A közegek áramoltatását a DCMD 
eljárás alapján végeztem, hőmérsékletkülönbség nélkül, így desztillátum valójában nem keletkezett, de az áramló közegek viselkedését a membránpórus-nedvesítés szempontjából meg tudtam figyelni.

Az LEP ${ }_{w}$ mérése során a betáplálás oldali nyomást emeltem 0,20 bar nyomással, a nyomásszabályozó szelep 5 percenkénti fokozatos elzárásával. A desztillátum oldalon állandó, 0,10 bar túlnyomás uralkodott. Abban a pillanatban, amikor a transzmembrán nyomáskülönbség elérte az LEP $_{\mathrm{w}}$ értékét, a betáplálási folyadékáram nedvesíteni kezdte a pórusokat és a desztillátum oldali vezetőképesség ugrásszerűen megnőtt, valamint a desztillátum tömege is el kedzett növekedni. Az ebben a pillanatban fenálló transzmembrán nyomáskülönbséget tekintettem az $\mathrm{LEP}_{\mathrm{w}}$ értékének adott hőmérsékleten.

Ezután a hiszterézis kimérése következett. A rendszerben maximálisan létrehozható transzmembrán nyomáskülönbségről fokozatosan csökkentve (0,20 bar), egészen nyomáskülönbség megszünéséig mértem a desztillátum fluxusokat. A fluxus az egységnyi idő alatt, egységnyi felületen áthaladt szürletet jelenti (6):

$$
J=\frac{1}{A} \frac{\Delta m}{\Delta t}
$$

ahol $J$ a szürlet fluxusa, $\mathrm{kgm}^{-2} \mathrm{~h}^{-1} ; \Delta m$ a desztillátum tömegének változása, $\mathrm{kg} ; A$ a hasznos membránfelület, $\mathrm{m}^{2}, \Delta t$ a mintavételezési időintervallum, $\mathrm{s}$.

Így ábrázoltam a kapott fluxusértékeket a transzmembrán nyomáskülönbségek függvényében az $\mathrm{LEP}_{\mathrm{w}}$ mérésekkel együtt - melyböl egyértelmüen megállapítható a membrán LEP ${ }_{\mathrm{w}}$ értéke és hiszterézis karaktere.

Itt fontos megjegyezni, hogy a csöves membránmodul esetében a statikus módszer kivitelezésére nem került sor, mivel az üreges membránokat eltávolítani csak a modul teljes tönkretételével lehetett volna végrehajtani. Így ebben az esetben csak az új dinamikus módszer, valamint a gyártó által megadott adatok álltak rendelkezésre, melynek pontos mérési módszerét a gyártó nem közölte.

\subsubsection{VMD elrendezés felépítése és $L E P_{w}$ mérése}

A 17. ábra szemlélteti a kísérleti berendezést az $\mathrm{LEP}_{\mathrm{w}}$ mérésére új, dinamkus módszerrel, VMD elrendezésben. A 4.1.1 alfejezeteben már ismertetett lapmembránt és szendvics modult alkalmaztam ebben a konfigurációban is. A betáplálás $35 \mathrm{Lh}^{-1}$ térfogatárammal áramlott a modulban, ami $R_{\text {betáp }}=900$, lamináris áramlási jelleget eredményezett. A desztillátum oldalon vákuum szivattyút 
(Büchi Labortechnik AG., Model V-700/ V-850, Flawil, Svájc) alkalmaztam, követve a VMD elrendezés követelményeit. Ebben a kialakításban kondenzátorra nem volt szükségünk, mivel az LEP értékéig nem képződött folyadékállaputú desztillátum, az LEP értéket elérve pedig a pórusok folyadékfázisú elárasztása következett, így a kondenzátor alkalmazása felesleges. Ebben az esetben is digitális mérleget használtam a fluxus értékének megállapításához, amely a hiszterézisgörbe felállításához volt szükséges.

A betáplálási és desztillátum oldalon elhelyezett nyomás- és hőmérsékletérzékelők, valamint a digitális mérleg is a 4.1.2.1. alfejezetben ismertetett interfészhez voltak kapcsolva.

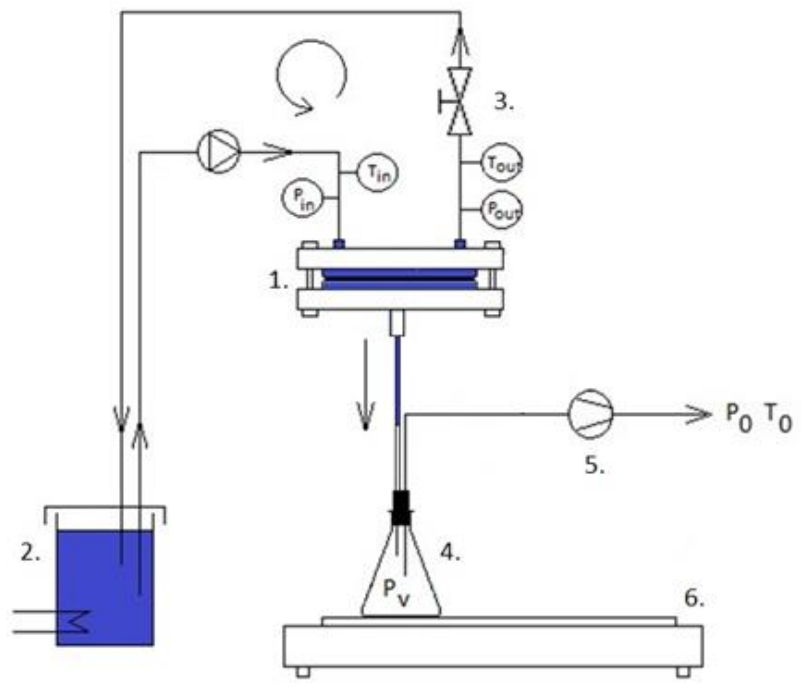

17. ábra Durapore ${ }^{\mathrm{TM}}$ GVPH lapmembrán LEPW értékének és hiszterézisének meghatározása VMD elrendezésben, dinamikus módszerrel (1. lapmembrán szendvics modulban, 2. betáplálás, 3. szelep, 4. desztillátum gyüjtő edény, 5. vákuum pumpa, 6. digitális mérleg)

Az LEP $_{\mathrm{w}}$ kiméréséhez először vákuum nélkül, csak a betáplálás oldali nyomást emeltem 0,20 bar-ral, 5 percenként, egészen 1,20 bar-ig. Ez a nyomásérték volt a 17. ábrán látható kialakításban alkalmazott szivattyú felső korlátja. Mikor elértem az 1,20 bar értéket, és a nedvesedés még nem történt meg, bekapcsoltam a vákuumszivattyút, és innen folytattam a transzmembrán nyomáskülönbség növelést, lépésenként. A maximális vákuumérték, melyet ezzel a felépítéssel el lehetett érni, 60 mbar(a) (-0,94 bar(g) légköri nyomáshoz viszonyított negatív nyomás) volt, így az ebben a rendszerben elöállítható, maximális transzmembrán nyomáskülönbség 2,14 bar érték volt. Amikor a betáplálás legyőzve a kaplilláris erőket - nedvesítette a membrán pórusait, egy gyorsan mozgó meniszkuszt lehetett észrevenni a desztillátum oldali elvezetőcsőben, és a szürlet tömege is növekedni kezdett. Az 
ekkor fenálló nyomáskülönbséget tekintettem az $\mathrm{LEP}_{\mathrm{w}}$ értékének. A hiszterézis görbe kimérésénél a 4.1.2.1 fejezetbel kifejtett módszert követtem.

\subsubsection{Nedvesedett membránpórusok regenerálásának lehetőségei}

\subsubsection{Regenerálás magas hőmérsékleten}

$\mathrm{Az} \mathrm{LEP}_{\mathrm{w}}$ meghatározása után a membránok pórusai teljes egészében átnedvesedtek a betáplálási folyadékárammal. Ahhoz, hogy a membránokat újra membrándesztillációs célokra használhassuk, elengedhetetlenül szükséges a pórusokban levő nedvesség teljes eltávolítása. Ennek egyik kézenfekvő megvalósítási módja a hőmérséklet emelésével való nedvesség-elpárologtatás, szárítás.

Mindkét viszgált membrántípus (Durapore ${ }^{\mathrm{TM}}$ GVPH lapmembrán és a MD $020 \mathrm{CP} 2 \mathrm{~N}$ csöves membrán) estetében alkalmaztam ezt a módszert. Továbbá ahhoz, hogy az összes nedvességet a lehető leghatékonyabban távolíthassam el a pórusokból, vizsgáltam a nedvesedett membránok etanollal való kezelésének hatékonyságát is. Az etanol „kimossa” a pórusokból a vizet, és magasabb gőztenziója miatt könnyebb annak kihajtása.

Az etanolos öblítés esetében a szárítás előtt $96 \mathrm{v} / \mathrm{v} \%$-os etanolt öblítettem át a nedvesedett membránokon 30 percen keresztül, 0,3 bar transzmembrán nyomáskülönbség mellett. Ez után friss, 96 v/v\%-os etanolban tároltam egy napig a membránokat. Majd pedig a szárítás következetett, melyet egy szárítószekrényben végeztem el $50^{\circ} \mathrm{C}$-on, 48 óráig. $\mathrm{Az} 50^{\circ} \mathrm{C}$ a csöves modul hőtürése miatt lett kiválasztva, ez volt a maximális üzemeltetési hőmérséklete. A lapmembrán (Durapore ${ }^{\mathrm{TM}} \mathrm{GVPH}$ ) esetében a membránt a szendvics modulból kivettem és csak magát a membránt szárítottam. A csöves membrán modul esetében a membránokat nem tudtam kivenni a modulból, mivel azok gyárilag rögzítve voltak abban, így az egész modult helyeztem a szárítószekrénybe. Három párhuzamos mérést végeztem.

A szárítás után mind az etanolos, mind pedig az etanol nélküli módszer sikerességét ellenőriztem. A regenerálás sikerességét lapmembrán esetében a szendvicsmodulba visszahelyezve, a 4.1.2.2. alfejezetben leírt VMD elrendezésben ellenőriztem, kiegészítve egy kondenzátorral $\left(\mathrm{T}_{\text {betáp }}=40^{\circ} \mathrm{C}, \mathrm{Re}_{\text {betáp }}=500, \mathrm{P}_{\text {vákuum }}=60 \mathrm{mbar}(\mathrm{a})\right)$, alacsony koncentrációjú sóoldat $\left(0,36 \mathrm{mScm}^{-1}\right.$, $24,7{ }^{\circ} \mathrm{C}$-on) betáplálása mellett. A csöves membrán modul regenerálásának sikerességét pedig DCMD elrendezésben ellenőriztem a 4.1.2.1. alfejezetben ismertetett üzemeltetési paraméterekkel, $8^{\circ} \mathrm{C}$-os hőmérsékletkülönbség mellet $\left(\mathrm{T}_{\text {betáp }}=25^{\circ} \mathrm{C}, \quad \mathrm{T}_{\text {deszt }}=17^{\circ} \mathrm{C}, \quad \mathrm{Re}_{\text {betáp }}=260, \quad \mathrm{Re}_{\text {deszt }}=170\right)$, alacsony 
koncentrációjú sóoldattal betáplálásként $\left(0,36 \mathrm{mScm}^{-1}, 24.7{ }^{\circ} \mathrm{C}\right.$-on $)$. Szükséges volt valódi szétválasztást megvalósítani, hogy lássam, mekkora mértékben lett sikeres a regeneráció.

Mindkét esetben mértem az előállított desztillátum vezetőképességét, és ha ez az érték a müszer kimutathatósági értéke alatt volt $\left(0,01 \mathrm{mScm}^{-1}\right)$, akkor a regenerálást sikeresnek tekintettem.

\subsubsection{Regenerálás vákuum segítségével}

A magas hőmérséklet mellett csökkentett nyomású légtérben, azaz vákuum alkalmazásával is növelhetjük a párolgás sebességét, száríthatunk hatékonyan akár szobahőmérsékleten is. Ebben az esetben nem szükséges a rendszer és modulok teljes szétszerelése, emiatt sokkal praktikusabbnak bizonyul. Így vákuum segítségével is vizsgáltam a nedvesedett lapmembrán (Durapore ${ }^{\mathrm{TM}}$ GVPH) és csöves membrán modul (MD $020 \mathrm{CP} 2 \mathrm{~N})$ pórusainak regenerálási lehetőségét, etanolos kezeléssel és kezelés nélkül egyaránt. Az etanolos kezelés eljárása megegyezett a 4.1.3.1. alfejezetben ismertetett eljárással.

A vákuummal megkísérelt nedvesség eltávolítás hatékonyságát annak függvényében is vizsgáltam, hogy a vákuumot a membrán melyik oldalán alkalmazzuk. Három összeállítás adódott: vákuum a betáplálás oldalról, vákuum a desztillátum oldalról, és vákuum mindkét oldaról, egyidőben alkalmazva. Ezek megvalósítását a 18. ábra illusztrálja.

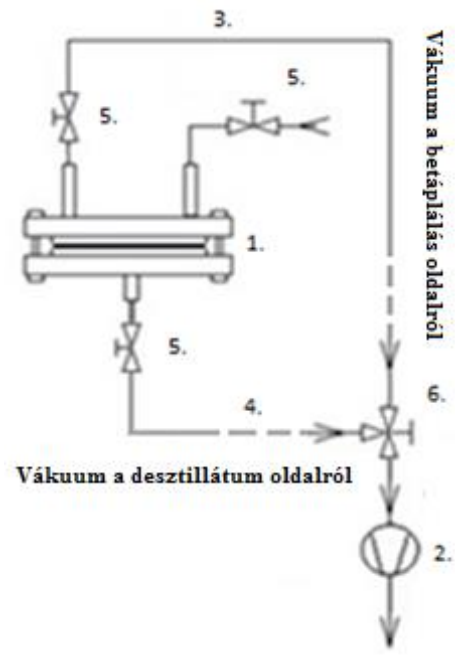

18. ábra Átnedvesedett pórusú membránok regenerálásának vizsgálata vákuum segítségével (1. átnedvesedett lapmembrán vagy csöves membrán, 2. vákuumpumpa, 3. vákuum alkalmazása a betáplálás oldalról, 4. vákuum alkalmazása a desztillátum oldalról, 5. szelep a levegő térfogatáramának szabályozására, 6. kapcsoló a különböző kapcsolási módok között). 
A vákuumos regenerálási eljárás folyamatábrája a M.III. mellékletben található. Az összes kapcsolási mód esete szobahőmérsékleten $\left(25^{\circ} \mathrm{C}\right)$ és 150 mbar vákuum alkalmazásával történt (az adott mérési kialakításban és a rendelkezésre álló vákuumpumpával ez volt a legnagyobb vákuumérték, amit elő tudtam állítani). Először egy nagynyomású levegőáramot alkalmaztam mind a betáplálás, mind pedig a desztillátum oldalán, a membrán felületén levő folyadékcseppek eltávolítására. Ezután következett a vákuumos szárítás, mind a három esetet vizsgálva, külön-külön. Elöször 30 perces kezeléseket alkalmaztam, és ha ez az ellenőrzés során kimutathatóan nem hozott sikert, rendre további 5 perccel növeltem $(35,40,45$ perc) a vákuumozási időt. A regenerálás hatékonyságának sikerességét a 4.1.3.1. alfejezetben leírt módszerrel ellenőriztem. Három párhuzamos mérést végeztem.

\subsection{Olaj-víz (O/V) emulzió szétválasztása vákuum-membrándesztilláció segítségével}

Ha egy membrándesztillációs rendszerbe betáplált folyadékáram valamilyen szerves fázist, és/vagy felületaktív anyagot tartalmaz, az LEP értéke drasztikusan megváltozhat (5), és a membránpórusok nedvesedése alacsonyabb transzmembrán nyomáskülönbség mellett megtörténhet. Továbbá, ha olaj-avízben emulzióról van szó, a diszpergált olajcseppek koncentrációja és méreteloszlása szintén hatással lehet az LEP értékére, és a szétválasztás mértékére, sebességére.

A következő alfejezetben ismertetem azokat az anyagokat és módszereket, melyekkel az LEP változását követtem nyomon a membrán olaj-a-vízben $(\mathrm{O} / \mathrm{V})$ emulzióval való érintkeztetése során, statikus és dinamikus módszerrel. Ezek alapvető eszközeit és módszereit már a 4.1-es fejezetben ismertettem, az esetleges eltéréseket ezen alfejezeten belül mutatom be.

Az alfejezet második részében $\mathrm{O} / \mathrm{V}$ elmuzió VMD konfigurációval való szétválasztásához szükséges anyagokat és módszereket, valamint a kísérletek kiértékeléséhez szükséges fogalmakat mutatom be.

\subsubsection{LEP érték változásának vizsgálata a model $\mathrm{O} / \mathrm{V}$ emulzió összetételének függvényében statikus módszerrel}

Az LEP mérését statikus módszerrel a 4.1.1-es alfejezetben bemutatott szendvicsmodulban elhelyezett lapmembránnal és berendezéskialakítással végeztem el. A vizsgálatokhoz szükséges betáplálási emulziót egy EmulsiFlex-C5 (Avestin Inv. Kanada, Ottawa) nagy nyomású homogenizátorral állítottam elö, $50 \mathrm{MPa}$ nyomáskülönbség mellett, desztillált víz és nyersolaj felhasználásával. Egy törzsoldat elkészítése után, hígítással állítottam be a különböző összetételeket, melyek 0-3200 ppm olajkoncentráció között állítottam be, amely értékek beállításához egy összes szerves komponenst elemzö müszert alkalmaztam (TOC V CHS instrument, Shimadzu Corp. Japan, 
Kyoto). Az elkészült emulziók diszpergált szemcseméret eloszlását egy, a fény szóródása alapján müködő (,,light-scattering”) (MASTERSIZER, Malvern Instrument Ltd, UK, Worcestershire) részecskeméret meghatározóval vizsgáltam. Az emulziókat úgy állítottam be, hogy az átlagos szemcseméret 1,2 - 1,5 $\mu \mathrm{m}$ között legyen (19. ábra). Minden egyes esetben sikerült egy hasonló, monodiszperz emulziót elő́llítanom.

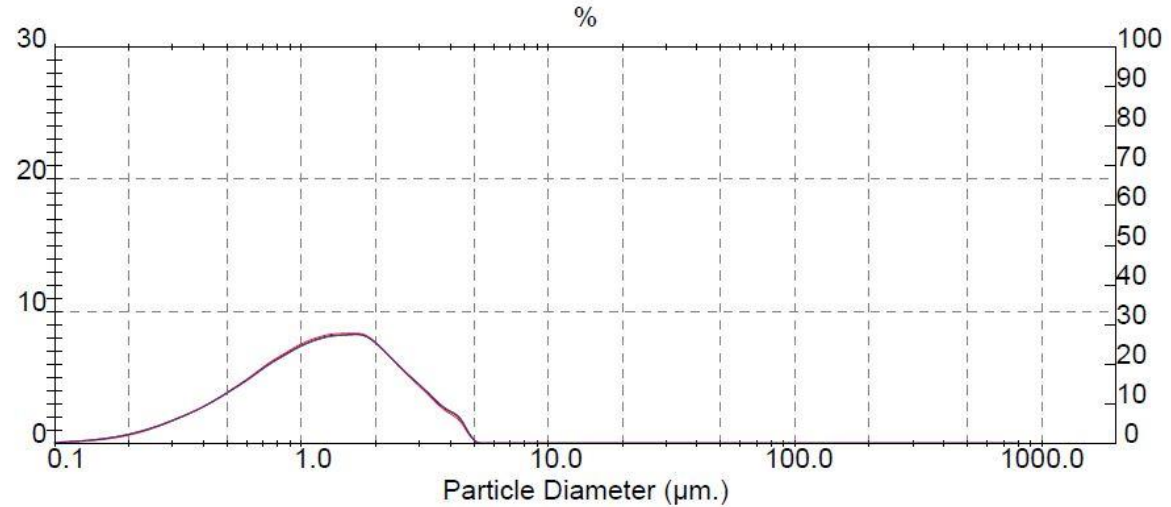

19. ábra Törzsoldat jellemző részecskeméret-eloszlása; átlagos átmérők: $\mathrm{D}(\mathrm{v}, 0.1)=0.43 \mu \mathrm{m}$, $\mathrm{D}(\mathrm{v}, 0.5)=1.24 \mu \mathrm{m} \mathrm{D}(\mathrm{v}, 0.9)=2.85 \mu \mathrm{m}$ (Range Lens: 300RF mm, Beam Length: $2.40 \mathrm{~mm}$, Obscuration: $17.4 \%)$.

Ez a mérettartomány a mérések szempontjából egy viszonylag stabil emulziót eredményezett (egy nap alatt nem képződött szerves felúszó fázis). Egyéb felületaktív anyagot az emulziók stabilitására nem alkalmaztam, mivel ezek közvetlenül befolyásolhatták volna az LEP mérését, így meghiúsítva az olaj valódi hatásának feltérképezését.

\subsubsection{LEP érték változásának vizsgálata a model $\mathrm{O} / \mathrm{V}$ emulzió összetételének függvényében dinamikus módszerrel}

A dinamikus módszer megvizsgálásához a 4.1.2.2. alfejezetben bemutatott VMD konfigurációt és szendvicsmodulba elhelyezett lapmembránt használtam. Ezeket a membránokat átnedvesedés után el lehetett dobni, így a mérések párhuzamos ismétlése megvalósítható volt, szemben a 4.1.2.1.-ben taglalt csöves membrán modullal, ahol annak tisztítása az olaj-víz emulzióval való érintekzése után rendkívül körülményes lett volna, és a nehezen visszamosható modullal ismételt mérések nem adtak volna hiteles eredményt.

Annak érdekében, hogy az olajtartalom valódi hatását az LEP értékére kimutathassam, ezeket a méréseket a következő, 4.2.3.-as alfejezetben ismertetésre kerülő VMD kísérletek után végeztem el. 
Így minden egyes koncentráció mellett a VMD művelet 5 óra hosszat volt üzemeltetve, így szimulálva egy esetleges valódi szeparálási müvelet hatását az LEP értékére.

Az emulziók előállítása itt is a 4.2.1. alfejezetben leírt módon történt. A hiszterézis görbék kimérésére itt is sor került a különböző betáplálási összetételek függvényében.

\subsubsection{O/V emulzió szétválasztásának vizsgálata vákuum-membrándesztillációs berendezéssel}

A kapcsolódó vizsgálatokat a 4.1.2.2. alfejezetben bemutatott VMD elrendezésben végeztem el, kiegészítve a rendszert egy gőzkondenzátorral, mely előállította az átdiffundált gőzfázisú desztillátum folyadék fázisát (20. ábra, 21. ábra).

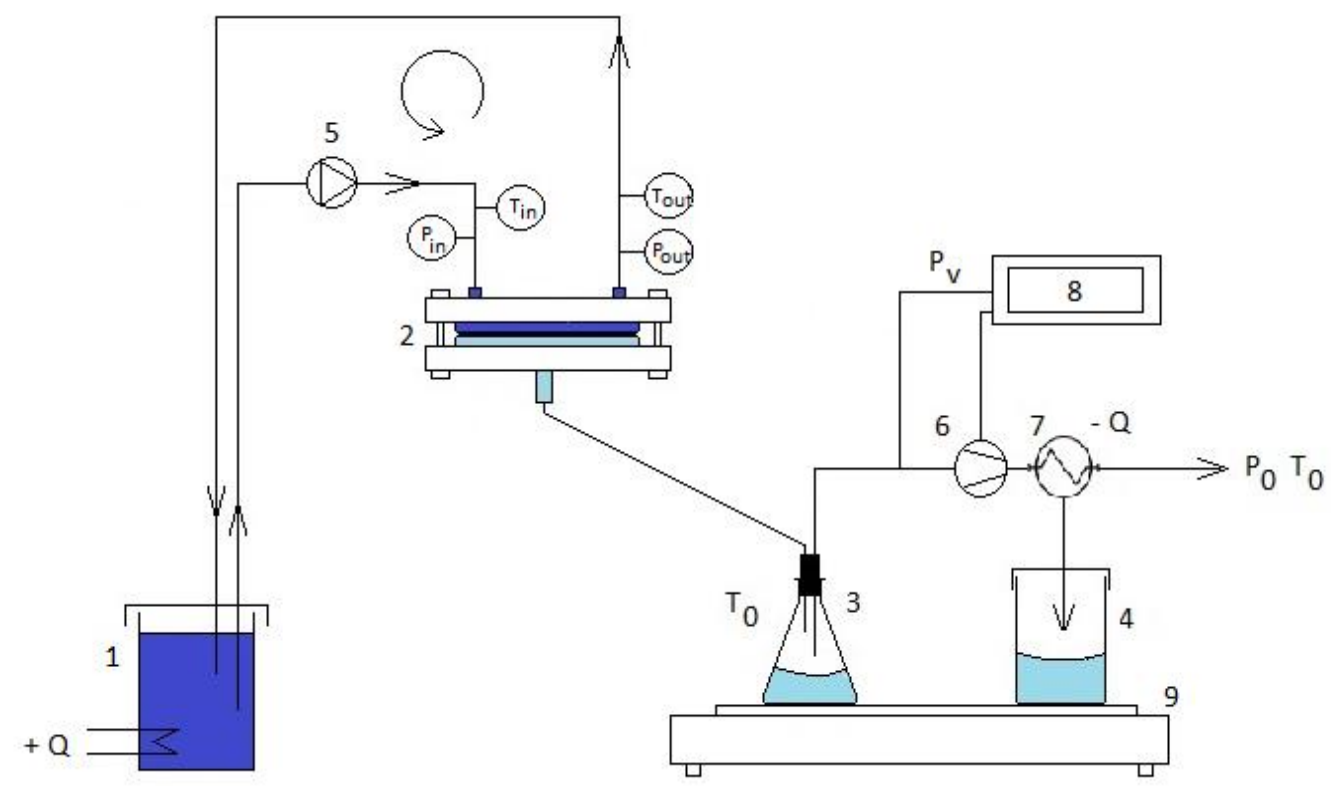

20. ábra VMD konfiguráció $\mathrm{O} / \mathrm{V}$ emulzió szétválasztására (1. betáplált $\mathrm{O} / \mathrm{V}$ emulzió,

2. szendvicsmodul a lapmembránnal, 3. elö-kondenzátumgyüjtö, 4. kondenzátum szedőedény, 5. perisztaltikus szivattyú, 6 . vákuum szivattyú, 7. kondenzátor, 8. vákuumérték kijelző, 9. digitális mérleg) 


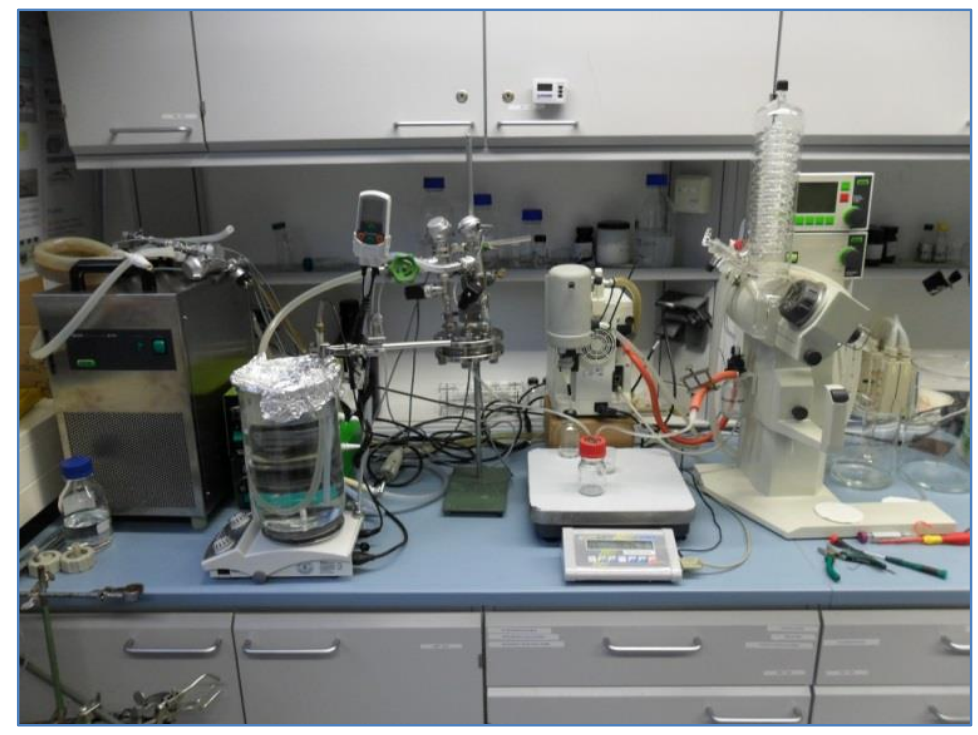

21. ábra A vákuum-membrándesztillációs kísérleti berendezés

A szükséges hajtóerő létrehozásához a betáplálási hőmérsékletet $50^{\circ} \mathrm{C}$-ra állítottam be, és a vákuumoldalon pedig 70 mbar(a) alacsony nyomást alkalmaztam.

$\mathrm{Az} 50^{\circ} \mathrm{C}$-os tiszta vízgőz telítési gőznyomása 122,3 mbar(a) (Antoine- egyenlet). A 24. ábrán látható 3-as jelzésű edényre azért volt szükség, mert a membrán pórusain áthaladt, telített állapotú, $50^{\circ} \mathrm{C}$-os desztillátum gőz egy része, érintkezve a környezeti hőmérsékletű ( $\left.\sim^{\circ} 25 \mathrm{C}\right)$ modul fém anyagával és desztillátum gyüjtő csővel, kondenzálni kezdett. A vákuumtérben uralkodó nyomásértéket 70 mbar állítottam be, melyhez a $39^{\circ} \mathrm{C}$ telítési hőmérséklet; ez alapján látszik, hogy a környezeti $25^{\circ} \mathrm{C}$ hőmérséklet elegendő a még alacsonyabb nyomásértéken törénő kondenzációhoz is. (Ha azt szerettük volna, hogy az összes desztillátumgőz a vákuumtér után kondenzáljon, a vákuumértéket a környzeti hőmérséklethez tartozó telítési gőznyomásérték alá kellett volna vinni $\left(\mathrm{T}=25^{\circ} \mathrm{C} ; 31 \mathrm{mbar}(\mathrm{a})\right)$, ami ebben a konfigurációban nem volt megvalósítható). Az esetleg még fennmaradt desztilláum gőzök a vákuum szivattyú után, légköri nyomáson egy $17^{\circ} \mathrm{C}$-os vízhütéses kondenzátorban kondenzáltak.

A kondezáció hatékonyságát előzetesen ellenőriztem, mely során mértem a betáplálás kiindulási és végső tömegét, továbbá a kapott desztillátum tömegét. Ebből tudtam párolgási veszteséget számolni, mely veszteség minden esetben 5\%-os érték alatt volt.

Mindkét szedőedény egy digitális mérlegen volt elhelyezve, és ez a mérleg rögzítette a desztillátum tömegének változását az idő függvényében, melyből a (6)-es egyenlet alapján a pillanatnyi 
desztillátum fluxus számítható volt. Majd egy teljes, 5 óra hosszúságú mủvelet után a kapott fluxusadatokból, a 22. ábrán látható módszerrel egy átlagos, ún. integrált fluxusértéket számítottam.

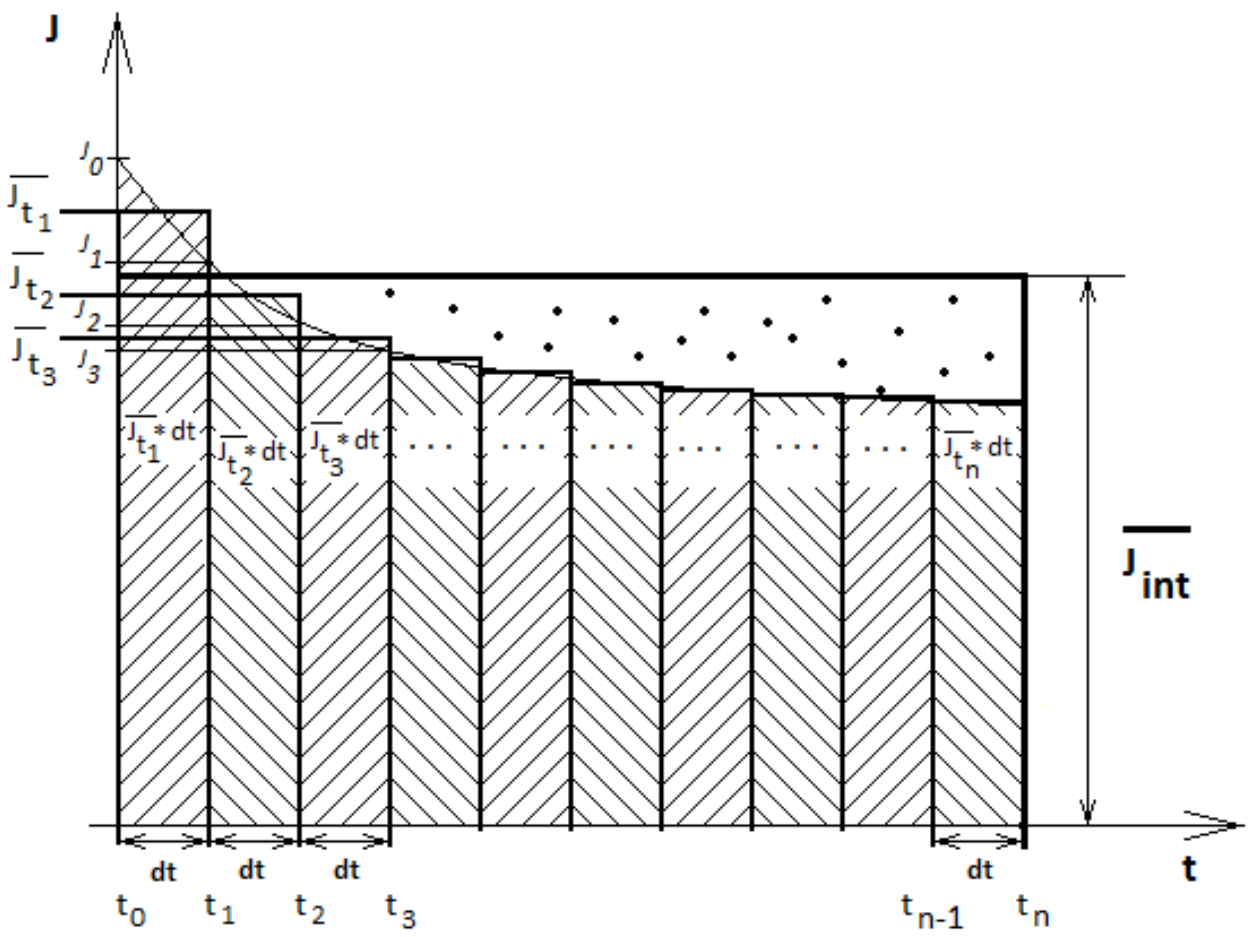

22. ábra Integrált fluxusérték képzése

Fontos megjegyeznem, hogy az elöállított desztillátum mennyisége (kb. 5 óra alatt $150 \mathrm{~g}$ desztillátum) a kiindulási betáplált elegy mennyiségének $(5 \mathrm{~kg})$ hozzávetőlegesen a 3\%-a volt, így ezt az eljárást „total recycle” eljárásmódnak tekintettem, ezzel azt feltételezve, hogy a betáplálás összetétele állandó. Ezek alapján, a folyamat során ezt a minimális koncentrációnövekedést nem tekintettem szignifikáns tényezőnek.

A különböző betáplálási összetétel előállításához, és a kapott desztillátum, valamint sürítmény minőségi meghatározásához a 4.2.1. alfejezetben bemutatott TOC és részecskeméret meghatározót használtam. 


\subsection{Anyagok és módszerek többlépcsős membrános eljárással való zsályahatóanyagok kinyerésére}

A következő alfejezetben a zsályakivonat kíméletes előállításához szükséges anyagokat és módszereket ismertetem.

\subsubsection{Felhasznált növényi részek és az extrakciós módszer}

A kísérletekhez szükséges görög zsálya (S. fruticosa Miller) a természetes élöhelyéről, Törökország nyugati, mediterrán éghajlatú területéről származott. A gyüjtése után a levelek szárítását levegőn, szobahőmérsékleten, árnyékos helyen végeztem el, annak egyensúlyi nedvességtartalmáig $(\sim 8 \mathrm{~g} / 100 \mathrm{~g})$. Az extrakciós eljárás egy egyszeri, forróvizes extrakció volt $\left(80^{\circ} \mathrm{C}\right), 1$ óra extrakciós idővel. Az alkalmazott oldószerarány $4 \mathrm{~g}$ száraz levél/100 mL forró víz volt. Az extrakció során a fözetet termosztáltam folyamatos keverés mellett, majd pedig egy $20 \mu \mathrm{m}$-es pórusméretü papírszürőn átszürtem a nagyobb levéldarabok és egyéb szilárd szennyeződések eltávolítása céljából. Az extrakció után $15 \mathrm{~L}, 0,9 \mathrm{~m} / \mathrm{m} \%$ szárazanyag tartalmú extraktumot kaptam, mely érték megállapításához egy kézi refraktométert használtam (Pal- $\alpha$ pocket, Atago, Tokyo, Japan).

\subsubsection{Alkalmazott membrán müveletek}

A 23. ábra mutatja az alkalmazott kapcsolt membrános müvelet folyamatábráját.

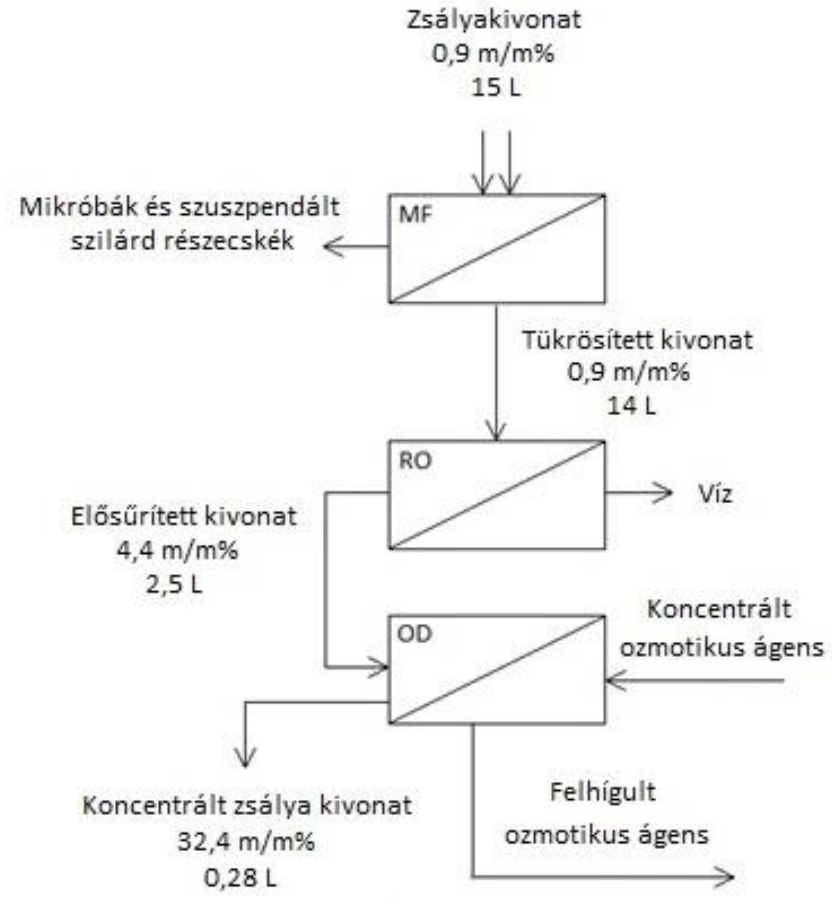

23. ábra Kapcsolt membrán müvelet zsályakivonat koncentrálására 
A folyamat három müveleti egységből épül fel: egy mikroszürésből (MF), egy fordított ozmózisból (RO) és egy ozmotikus desztillációs eljárásból (OD). A mikroszürés célja a hideg csírátlanítás, illetve a visszamaradt kisebb növényi részek eltávolítása. A fordított ozmózissal egy elősürítési lépést hajtottam végre, végül pedig az ozmotikus desztilláció célja volt a végsürítmény előállítása.

A 24. ábra mutatja a mikroszürő és a fordított ozmózisos berendezés felépítését. Az eljárás kezdete előtt az (1) jelü betáplálási tartályba töltöttem az extrakció során nyert friss zsályakivonatot. A (2) jelü hütörendszerrel tartottam az állandó müködési hömérsékletet. A (3) jelü elvezető csapon vezettem el a folyamat végén a retentátumot. A megfelelő transzmembrán nyomáskülönbséget, azaz a hajtóerőt a (4)-es jelü nyomás szabályozó szelepekkel állítottam be, az (5)-ös jelü elvezető cső a permeátum folyamatos elvételét szolgálta. A (6)-os jelü rotaméter a recirkulációs térfogatáram beállítását és ellenőrzését szolgálta. A (7)-es jelü membránbefogó modul tartalmazta a mikroszürő kerámia csőmembránt $0,45 \mu \mathrm{m}$ átlagos pórusmérettel, 0,125 $\mathrm{m}^{2}$ aktív szürőfelülettel (Schumasiv, Pall Corporation, NY, USA), ami fordított ozmózis során egy ACM2 jelzésű lapmembrán modult jelentett 0,18 m² aktív szürőfelülettel, 93\%-os sóvisszatartással (DDS, Silkeborg, Dánia).

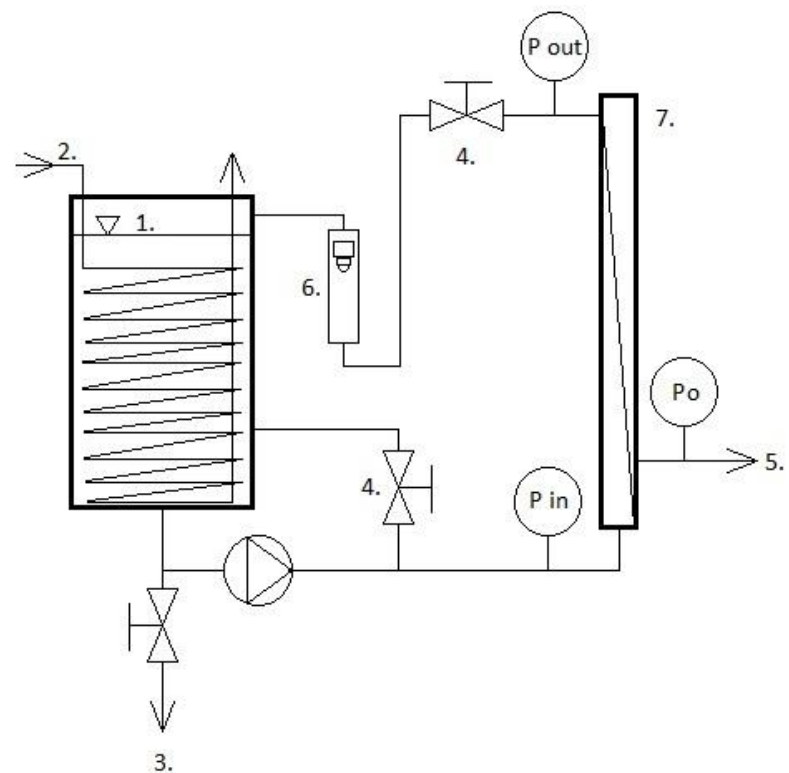

24. ábra Mikroszürő és fordított ozmozisos berendezés működési elve (1. betáplálási tartály, hütőrendszer, retentátum elvétel, 4. nyomás szabályozó szelepek, 5. permeátum elvétel, 6. rotaméter, 7. membrán befogó modul az MF, vagy RO membránnal)

A mikroszürés művelete $30^{\circ} \mathrm{C}$-on zajlott, a rögzített recirkulációs térfogatáram $500 \mathrm{Lh}^{-1}$ volt. A fordított ozmózis szintén $30^{\circ} \mathrm{C}$-on zajlott, rögzített, $600 \mathrm{Lh}^{-1}$ térfogatáram mellett. 
A permeátum fluxus megállapítását meghatározott időközönként, „köbözéssel” végeztem, azaz mértem az egységnyi idő alatt képződött szürlet térfogatáramát, és a (7)-as egyenlet alapján számítottam ki:

$$
J=\frac{V_{p}}{A t}
$$

ahol $J$ a permeátum fluxus, $\mathrm{Lm}^{-2} \mathrm{~h}^{-1}, V_{p}$ permeátum térfogata, $\mathrm{L} ; A$ a hasznos membránfelület, $\mathrm{m}^{2}, t$ a mérési időintervallum, $h$.

Továbbá egy úgynevezett sürítési arányt (,, volume reduction factor” - VRF) is definiláltam és használtam a jelenségek megfelelő szemléltetése céljából (8):

$$
V R F=\frac{V_{\text {Betáp }}}{V_{\text {Ret }}}
$$

ahol $V_{\text {Betáp }}$ a betáplálás kiindulási térfogata, $V_{R e t}$ pedig a retentátum végső térfogata.

Mind a mikroszürés, mind pedig a fordított ozmózisos méréseim során törekedtem arra, hogy meg tudjam határozni az ún. kritikus és limitáló fluxus értékeit, valamint az ehhez tartozó transzmembrán nyomáskülönbségeket, melyhez a következő módszert alkalmaztam. A betáplálás betöltése után „totalrecycle" módban üzemeltettem a berendezéseket, ami azt jelentette, hogy a képződő szürletet visszavezettem közvetlen a betáplálási tartályban. Így mértem különböző transzmembrán nyomáskülönbségek mellett a fluxust. Ez a módszer lehetővé teszi a fluxusértékek vizsgálatát úgy, hogy a növekvő betáplálás koncentráció hatását a folyamatos visszavezetéssel ki tudjuk küszöbölni, azaz állandó értéken tartani.

Mikroszürés esetén a kiindulási transzmembrán nyomáskülönbség 0,3 bar volt, és ezt a hajtóerőt 30 perces idöközönként 0,5 bar értékkel növeletem. A 30 perc elegendő volt a stacionárius körülmények létrehozásához. Fordított ozmózis esetén a kiindulási transzmembrán nyomáskülönbség 13 bar volt, és ezt az értéket pedig 5 bar-ral növeltem, szintén 30 perc elteltével. A kapott értékeket egy diagrammon szenmléltetem. Azt a pontot, ahol a permeátum fluxus és a transzmembrán nyomáskülönbség közötti függvénykapcsolat elveszti linearitását, jelöltem meg kritikus fluxusnak, és ahol a fluxus értéke függetlenné válik a transzmembrán nyomáskülönbségtől, limitáló fluxusnak neveztem.

Az ozmotikus desztilláció a 25. ábrán szemléltetett berendezésen zajlott le. 


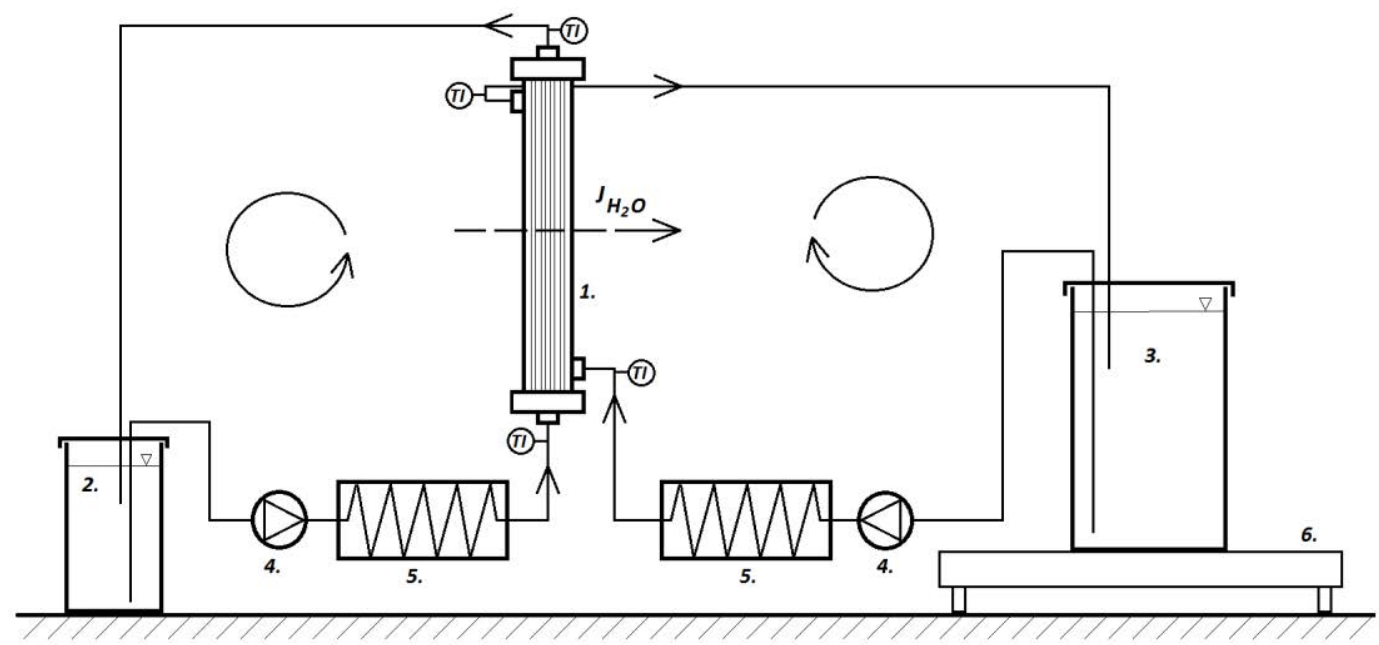

25. ábra Ozmotikus desztillációs berendezés felépítése (1. membrán modul, 2. betáplálási tartály,

3. ozmotikus ágens tartály, 4. perisztaltikus szivattyúk, 5. hőcserélők, 6. digitális mérleg)

A feladathoz az (1)-es jelü, mikroszürő polipropilén csőmembránt használtam (MD 020CP2N, Microdyn-Nadir GmbH, Wiesbaden, Németország), mely 0,1 $\mathrm{m}^{2}$ hasznos membránfelülettel, 0,2 $\mu \mathrm{m}$-es átlagos pórusmérettel rendelkezett. A müveletet szakaszos müveletként, szobahőmérsékleten, $25^{\circ} \mathrm{C}$-on végeztem el. A membrán csöveiben áramlott az elősürített zsályakivonat, a köpenytérben pedig az ozmotikus oldat. A recirkulációs térfogatáram a membrán mindkét oldalán $30 \mathrm{Lh}^{-1}$ volt, a közegeket ellenáramban áramoltattam. Ozmotikus ágensként $\mathrm{CaCl}_{2}$ oldatot használtam, kiindulási koncentrációja telített volt (42 m/m\%, $25^{\circ} \mathrm{C}$-on). Az ozmotikus oldat kiindulási mennyisége négyszer nagyobb volt (10 L), mint az elősürített zsályakivonaté (2,5 L), azért, hogy az ozmotikuss ágens hígulása okozta hajtóerőcsökkenés hatása minimális legyen. Mind a betáplálási zsályakivonat, mind pedig az ozmotikus oldat tartályát a párolgási veszteség hatásának minimalizálása céljából lefedtem. A (6)-os jelü digitális mérleg rögzítette az ozmotikus oldat tömegének változását az idő függvényében, amiből a 4.1.2.1-es fejezetben fellelhető (6)-os egyenlet alapján a desztillátum fluxusértékek számíthatóak voltak.

\subsubsection{Alkalmazott analitikai módszerek a bioaktív komponensek vizsgálatára}

\subsubsection{Spektrofotometriás eljárások az összes polifenol tartalom, az összes flavonoid tartalom és antioxidáns kapacitás meghatározásához}

Az összes polifenol tartalom (TPC - total phenolic content) mérését a SINGLETON és ROSSI (1965) által használt, módszerrel végeztem el. A módszer elnevezése nem teljesen pontos, mivel nemcsak a fenolok, hanem a vízoldható, elektronátadásra képes antioxidánsok vizsgálatára is alkalmas (HEGEDÜS 2012). 765 nm-es hullámhosszon határoztam meg spektrofotometriás készülékkel 
(Shimadzu UV-Vis160A, Japán). A kapott értékeket galluszsav-egyenértékre határoztam meg (mg GSE/ml kivonat).

Az összes flavonoid tartalom (TFC - total flavonoid content) meghatározását a következőek alapján történt (CHANG et al. 2002). A minta abszorbanciáját $510 \mathrm{~nm}$-en mértem meg, és a kapott koncentráció értéket $(+)$ katechin egyenértékben fejeztem ki (mg $(+) \mathrm{KE} / \mathrm{mL}$ kivonat).

Blois alapján az antioxidáns kapacitást a stabil DPPH gyök megkötésén alapuló módszer segítségével határoztam meg (BLOIS 1958). A reakció a követekzőképpen zajlik: a sötétlila színű gyök antioxidánsokkal reagálva elveszti színét. Széles körben alkalmazzák, mert a molekula kereskedelmi forgalomban kapható, stabil, kevésbé reakcióképes és kevésbé agresszív, ami a lezajló reakció során hasznos, a mérés egyszerü (HEGEDÜS és STEFANOVITS-BÁNYAI 2012).

\subsubsection{Polifenolok vizsgálata nagy teljesítményü folyadékkromatográfiás analitikai módszerrel}

A polifenolok vizsgálatát nagy teljesítményü folyadékkromatográfiás analitikai módszerrel (HPLC) végeztem el. A polifenolok HPLC-s vizsgálatához a következő mintaelőkészítési módszert alkalmaztam. 0,5 mL mintához $40 \mathrm{~mL}, 65,5 \%$-os metanolt adtam hozzá, mely $1 \mathrm{gL}^{-1}$ BHT-tartalmazott. Óvatos keverés mellet $10 \mathrm{~mL} 6$ mólos $\mathrm{HCl}$ oldatot adtam hozzá. Minden lépés során nitrogén buborékoltattam át a mintán, 60 s-ig. Ezután 15 perces ultrahangos kezelés következett, majd hagytam visszahülni szobahőmérsékletre a mintát. Továbbá, metanolt adtam a mintához úgy, hogy a mintát 100 mL-re egészítettem, majd pedig egy $0,45 \mu \mathrm{m}$ pórusméretü szürőn szürtem át (Macherey Nagel, Németország). A kromatografikus szétválasztás mintabevitelét egy 20AD (Shimadzu, Japán), automata mintaadagoló látta el (SIL-20A Shimadzu, Japán). Az alkalmazott oszlopok: (Lichro-CART ${ }^{\circledR} 250-4250 \mathrm{~mm}$ x 4mm $5 \mu \mathrm{m}$ Nucleosil ${ }^{\circledR} 5 \mathrm{C} 18$ ), továbbá egy $30^{\circ} \mathrm{C}$ oszlop termosztáló berendezés (CTO-20Ac, Shimadzu, Japán). Az egyes csúcsokat egy SPD-M20A diódasoros detektorral (Shimdazu, Japán) állapítottam meg, melyet egy LC Solution nevű szoftverrel értékeltem ki.

Mobil fázisként a következő keverékeket használtam: víz/ecetsav/metanol (88/2/10 v/v/v - „Solvent A”) és metanol/ecetsav/víz (90/2/8 v/v/v - „Solvent B”). 0,9 mL min ${ }^{-1}$ térfogatáram mellett a következő beállítást használtam: kezdeti A:B 100:0, 15 percnél A/B 85:15, 25 percnél A:B 50:50, 35 percnél A:B 30:70, 50 percnél 25:75 és 55 percnél A:B 0:100. 
Az egyedi polifenolos vegyületek megállapításához a következőket végeztem el. A minta $20 \mu \mathrm{L}$-ét vittem fel az oszlopokra, és az elkülönülö csúcsok a saját hullámhosszukon a maximum abszorbanciánál elemeztem ki (280 nm - heszperetin, $320 \mathrm{~nm}$ - kávésav, p-kumársav, ferulasav, rozmaringsav, $335 \mathrm{~nm}$ - apigenin, $350 \mathrm{~nm}$ - rutin).

\section{4. Új ozmotikus oldatok vizsgálata}

\subsubsection{Különböző ozmotikus oldatok hatékonyságának összehasonlítása}

A vizsgálatok végrehajtásához szükséges szervetlen sókat szilárd, kristályos formában szereztem be, majd készítettem belőle ioncserélt víz hozzáadásával telített oldatokat. Az 1. táblázat mutatja a felhasznált szervetlen sók oldhatóságát. Az elkészített oldatokat a 25. ábrán bemutatott laboratóriumi ozmotikus desztillációs berendezésen vizsgáltam. Minden oldatból $1000 \mathrm{~g}$ mennyiséget állítottam elö, és ezeket vizsgáltam $30^{\circ} \mathrm{C}$-on. A desztillátum fluxusok megállapításához itt is a 4.3.2-es alfejezetben kifejtett módon jártam el.

1. táblázat vizsgált szervetlen sók oldahtósága $\left(30^{\circ} \mathrm{C}, 101,3 \mathrm{kPa}\right)(\mathrm{PERRY} 1984)$

\begin{tabular}{|c|c|c|}
\hline Szervetlen sók & Oldhatóság 30 ${ }^{\circ} \mathbf{C}-\mathbf{o n}, \mathbf{g} / \mathbf{1 0 0 g}$ víz & Oldhatóság 30 ${ }^{\circ} \mathbf{C}-\mathbf{o n}, \mathbf{m} / \mathbf{m} \%$ \\
\hline $\mathrm{CH}_{3} \mathrm{COOK}$ & 283,8 & 73,95 \\
\hline $\mathrm{NH}_{4} \mathrm{NO}_{3}$ & 241,8 & 70 \\
\hline $\mathrm{Ca}\left(\mathrm{NO}_{3}\right)_{2}$ & 152,6 & 60,41 \\
\hline $\mathrm{K}_{2} \mathrm{CO}_{3}$ & 113,7 & 53,2 \\
\hline $\mathrm{CaCl}_{2}$ & 102 & 50 \\
\hline $\mathrm{NaNO}_{3}$ & 96 & 48,98 \\
\hline$\left(\mathrm{NH}_{4}\right)_{2} \mathrm{SO}_{4}$ & 78 & 43,8 \\
\hline $\mathrm{KNO}_{3}$ & 45,8 & 31,41 \\
\hline $\mathrm{NaCl}$ & 36,3 & 26,63 \\
\hline
\end{tabular}

\subsubsection{Kiválasztott ozmotikus oldat esetén a desztillátum fluxusára ható múveleti paraméterek hatásának vizsgálata}

A különböző ozmotikus ágensek által maximálisan kinyerhető desztillátum fluxus alapján kiválasztottam a leghatékonyabbat. Ezt követően ehhez kapcsolódóan kiválasztottam azokat a müveleti paramétereket, melyek az irodalom alapján a legnagyobb hatást fejthetik ki. Ezek a betáplálás hőmérésklete, az ozmotikus ágens koncentrációja, és a betáplálás és az ozmotikus oldat 
höméréskletének különbsége. A szakirodalmi adatok alapján, $\mathrm{CaCl}_{2}$ ozmotikus oldat eredményei alapján várható volt mind a három szignifikáns hatása.

A $2^{\mathrm{p}}$ típusú teljes faktoranalízis kísérletterv alapján elvégzett mérések eredményeinek kiértékelésére regressziós elemzést alkalmaztam. A regressziós elemzés lehetővé teszi a vizsgált faktorok (müveleti paraméterek) hatásának modellezését a vizsgált értéktartományon belül. A regressziós elemzés nem csak az egyes faktorok főhatását, hanem azok kölcsönhatását, vagy más néven együttes hatását is figyelembe veszi (ún. interakciós hatás).

A hatások vizsgálatához variancia analízist (ANOVA) is elvégeztem, mely lehetővé teszi a faktorszintek váltása következtében elöállt szórásnak és a kísérlet szórásának az összehasonlítását. Ennek segítségével meghatározható, hogy az egyszerü hatásszámítással kimutatott főhatások és kölcsönhatások a faktorok és kombinációik tényleges befolyását mutatják-e, vagy egyszerủen csak a véletlen változékonyságnak tudhatóak be.

Három paraméter esetén ez tizenegy mérési pontot jelent; nyolcat a szélső értékek különböző kombinációival és három ismétlést a középpontban. A műveleti paraméterek értékeit a 2. táblázat foglalja össze, a kísérletterv menetét az M.IV. melléklet mutatja be. A választott betáplálás hömérésklet felső határa az értékes komponensek megőrzése céljából általában megjelölt hőmérsékletet választottam. Hőméréskletkülönbségnek pedig a rendelkezésre álló hütőkapacitás szabott határt, mivel ebben az esetben a legalacsonyabb ozmotikus oldat hömérésklet $17^{\circ} \mathrm{C}$ höméréskletet jelentett (ez volt a a minimum, amit a müködő rendszerben tartósan fennt tudtam tartani).

A kiválasztott koncentrációkat telítettségi értékben, százalékosan adtam meg. A szakaszos folyamatból folytonos rendszerbe történő váltásban a felhíguló ozmotikus oldatnak találnunk kell egy olyan reális minimum koncentrációt, mellyel a müvelet gazdaságosan elvégezhető. Ezért választottam a 25\%-ot alsó határnak, mert ez alatt a folyamat már túlságosan lelassul, és semmiféleképpen nem müködhet gazdaságosan. 
2. táblázat. $2 p$ típusú kísérletterv paramétereinek értékei

\begin{tabular}{|c|c|c|c|}
\hline Normál érték & $\Delta \mathbf{T},{ }^{\circ} \mathbf{C}$ & Telítettség $\mathbf{C}_{\text {sóoldat }}$ & $\mathbf{T}_{\text {betáp, }}{ }^{\circ} \mathbf{C}$ \\
\hline+ & 15 & $100 \%$ & 42 \\
\hline- & 5 & $25 \%$ & 32 \\
\hline 0 & 10 & $62,5 \%$ & 37 \\
\hline
\end{tabular}

\subsection{Meggysürítmény kíméletes sürítése kapcsolt membrános eljárással}

\subsubsection{Meggy, mint alapanyag}

Az Oblacsinszka fajtájú meggyet Újfehértóról szállíttatam, és préselés útján nyertem ki belőle a levet. A kimagozott és ledarált meggyet enzimes kezelés után egy átalakított szőlőpréssel kezeltem, és a kapott meggylevet ezután sürü szövésű vásznon átszürtem a durvább lebegő anyagok eltávolítása céljából. A kapott szürletet kiporcióztam, majd pedig fagyasztva tároltam a vizsgálat napjáig. Felolvasztáskor $4^{\circ} \mathrm{C}$-os hütőbe tettem, és igyekeztem elkerülni a fénnyel való érintkezés lehetőségét.

\subsubsection{Membrántechnológia}

A meggysürítésés vizsgálatokat a zsályakivonat koncentrálásához felhasznált berendezésekkel végeztem el, hasonló müveleti körülmények mellett (4.3.2. alfejezet). A 24. ábrán bemutatott mérési elrendezésben a lapmembrán modul mellett egy spirál tekercs modult is vizsgáltam (MFT Köln, CD1TYP3, Németország). Az alkalmazott recirculációs térfogatáram $500 \mathrm{Lh}^{-1}$, a műveleti hőmérséklet $30^{\circ} \mathrm{C}$, és a transzmembrán nyomáskülönbség kiindulási 40 bar volt. Az ellenállások kiszámolásához MD ALAM (2013) munkájában bemutatott mószert alkalmaztam.

Vízaktivitás méréseket végeztem egy Novasina LabMASTER-aw (Novasina AG, Lachen, Svájc), különböző koncentrációjú $\mathrm{CaCl}_{2}, \mathrm{CH}_{3} \mathrm{COOK}$ és meggylé vízaktivitásának, és abböl gőznyomásának megállapításához.

A dinamikus viszkozitások megállapítására Thermo Haake RotoVisco rotációs viszkoziméter segítségével történt a $\mathrm{CaCl}_{2}, \mathrm{CH}_{3} \mathrm{COOK}$ és meggylé viszkozitásainak meghatározására.

\subsubsection{Mikrobiológiai vizsgálatok}

A mikrobiológiaia vizsgálatok során fel kívántam térképezni, hogy a mikroszürés müvelete milyen hatékonysággal távolítja el a meggylében előforduló mikroorganizmusokat, melyek ronthatják a termék 
minőségét, csökkenthetik eltarthatóságát, esetleg patogének. Ennek céljából ISO szabvány szerinti összecsíraszámot és ozmofil élesztő- és xerofil penészgombaszámot végeztem el tenyésztés és lemezöntéssel. A preparált mintákat aszeptikus körülmények mellett vettem le, és a szabvány szerint inkubáltam $37^{\circ} \mathrm{C}$-on $18-24$ órát, majd $22^{\circ} \mathrm{C}$-on 3-5 napot.

\subsubsection{1. Összcsíraszám meghatározása lemezöntéssel}

A mosásra használt ioncserélt víz és a meggylé összecsíraszám meghatározását az MSZ ISO 4833:2003 szabványa alapján végeztem el. Sós peptonoldattal véghezvitt tízszeres hígítási sorral, tripton-glükóz-élesztőkivonat (TGY) agaron (Dichloran Rose Bengal Chloramphenicol Agar, 1.00466, Merck) lemezöntéssel végeztem el a vizsgálatot. A kapott eredményt CFU/ml mértékegységben adtam meg.

\subsubsection{Ozmofil élesztő- és xerofil penészgombaszám meghatározás lemezöntéssel}

A mosásra használt ioncserélt víz és a meggylé ozmofil élesztő- és xerofil penészgombaszám tenyésztés lemezöntéssel (ISO 21527-2:2008) DRBC agaron, Sós peptonoldattal véghezvitt tízszeres hígítási sorral (Dichloran Rose Bengal Chloramphenicol Agar, 1.00466, Merck) valósítottam meg. A kapott eredményt CFU/ml, iletve logCFU/ml mértékegységben adtam meg.

\subsection{Meggylé analitikai vizsgálatok}

A meggylé esetében összes polifenol tartalmat és antioxodáns hatást vizsgáltam. Az összes polifenol tartalmat a 4.3.3.1-es alfejezet alapján határoztam meg.

\subsubsection{Meggylé antioxidáns kapacitása FRAP módszer szerint}

A FRAP értékek meghatározása spektrofotometriásan $(\lambda=593 \mathrm{~nm})$ történt (Benzie and Strain, 1996). Az eredményeket L-(+) aszkorbinsavval készített kalibrációs görbe segítségével értékeltem ki. 


\section{EREDMÉNYEK}

\subsection{A membránpórus-nedvesedés jelenségéhez kapcsolódó kísérleti eredmények}

\subsubsection{LEP $P_{w}$ kísérleti meghatározásának eredményei statikus módszerrel}

$\mathrm{Az} \mathrm{LEP}_{\mathrm{w}}$ kísérleti értékének meghatározásához három párhuzamos mérést végeztem, minden mérésehez új Durapore ${ }^{\mathrm{TM}}$ GVPH lapmembránt használtam a 4.1.1. alfejezetben leírt módon. Így az

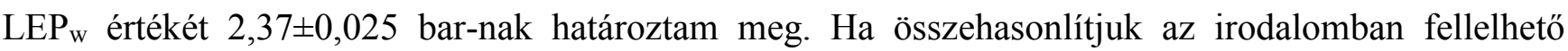

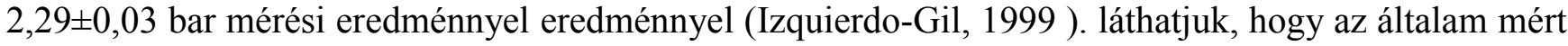
eredmény közel megegyezik ezzel, alátámasztva a statikus módszer reprodukálhatóságát és mérési eredményeim megbízhatóságát. Ez fog alapjául szolgálni az új, dinamikus módszer által kapott eredményekkel való összehasonlításhoz.

Összehasonlítva viszont a gyártó által közzétett, 2,04 bar értékkel, az általam kapott érték közel 15\%-os pozitív eltérést mutat. A gyártó nem tette közzé a mérési módszerét, így ennek az eltérésnek a pontos okáról adekvát módon nyilatkozni nem lehet - feltehetően a módszerek eltérésében lehet különbség.

\subsubsection{LEP $\mathbf{P}_{\mathrm{w}}$ kísérleti meghatározásának eredményei dinamikus módszerrel}

\subsubsection{VMD elrendezés eredményei és a hiszterézis megállapítása}

A 26. ábra az $\operatorname{LEP}_{\mathrm{w}}$ mérések eredményét mutatja Durapore ${ }^{\mathrm{TM}} \mathrm{GVPH}$ lapmembrán esetén, dinamikus módszerrel, VMD elrendezésben. Ha szemügyre vesszük, láthatjuk, hogy az adott mérési esetben 1,82 $\pm 0,1$ bar transzmembrán nyomáskülönbség mellett egy enyhén növekvő szürletfluxus volt érzékelhető. Ezt az értéket vehetjük a nedvesedési nyomás, azaz az LEP ${ }_{\mathrm{w}}$ értékének, itt kezdődött a pórusok lassú, de folyamatos nedvesedése. Ha összehasonlítjuk a M.II.-ben feltüntetett értékekkel

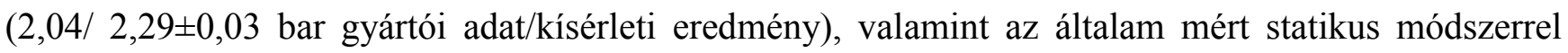
$(2,37 \pm 0,025$ bar) láthatjuk, hogy ez az eredmény egyértelmüen eltér ezektől. Ez arra enged következtetni, hogy a módszernek, mint olyan, határa van az LEP ${ }_{\mathrm{w}}$ értékére, valódi mérési körülményeket szimuláló módszer esetén a nedvesedés hamarabb történik meg, ami fokozott figyelmet igényel a müvelet végrehajtása során. 


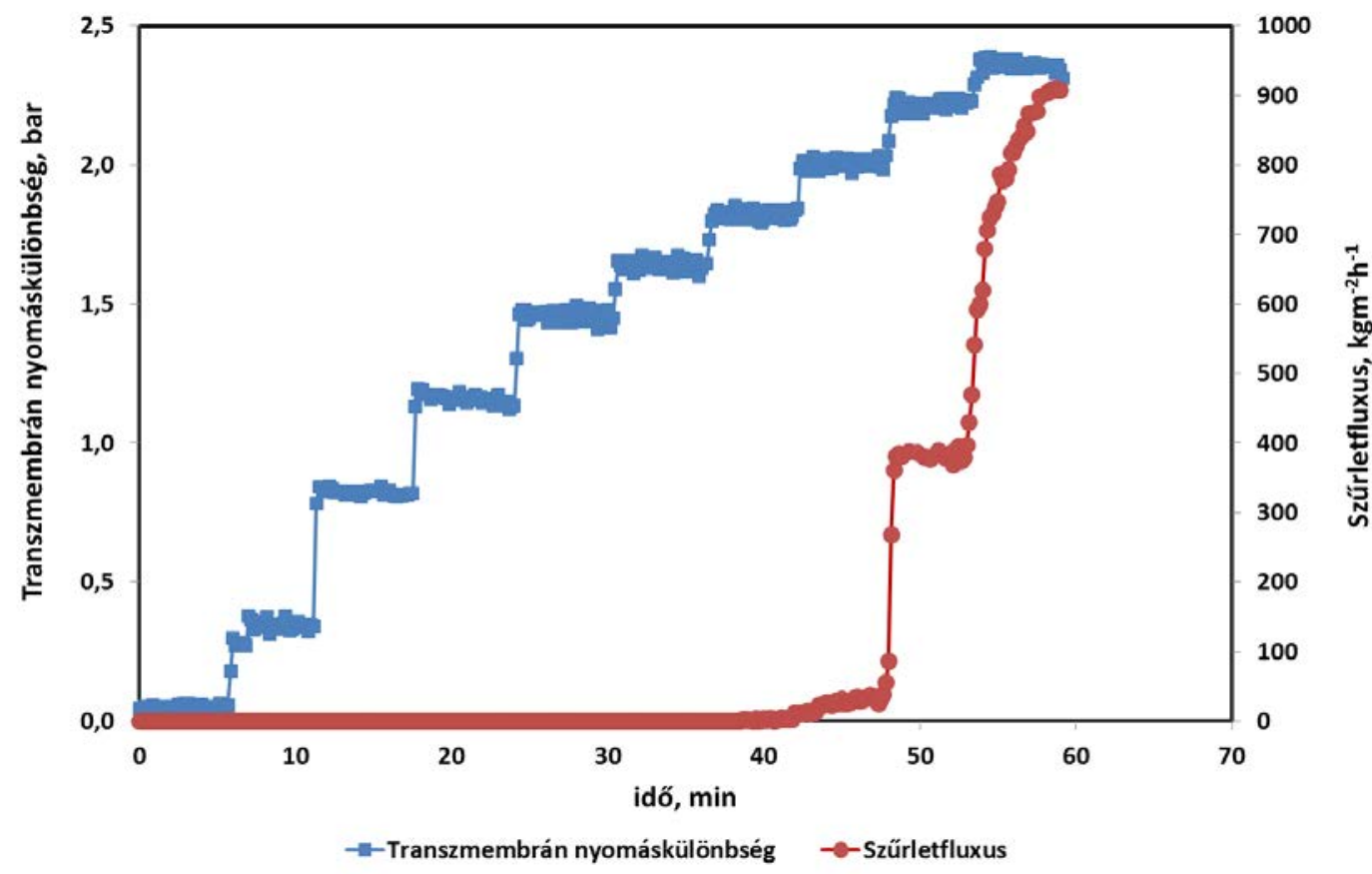

26. ábra Szürletfluxus az idő függvényében, növekvő transzmembrán nyomáskülönbség mellett lapmembrán (Durapore ${ }^{\mathrm{TM}} \mathrm{GVPH}$ ) esetén, szendvics modulban, VMD konfigurációban

A 27. ábra a lapmembrán hiszterézisét illusztrálja. Jól látszik, hogy az illesztett egyenes ebben az esetben $\mathrm{R}^{2}=0,76$ korrelációs együtthatót eredményezett.

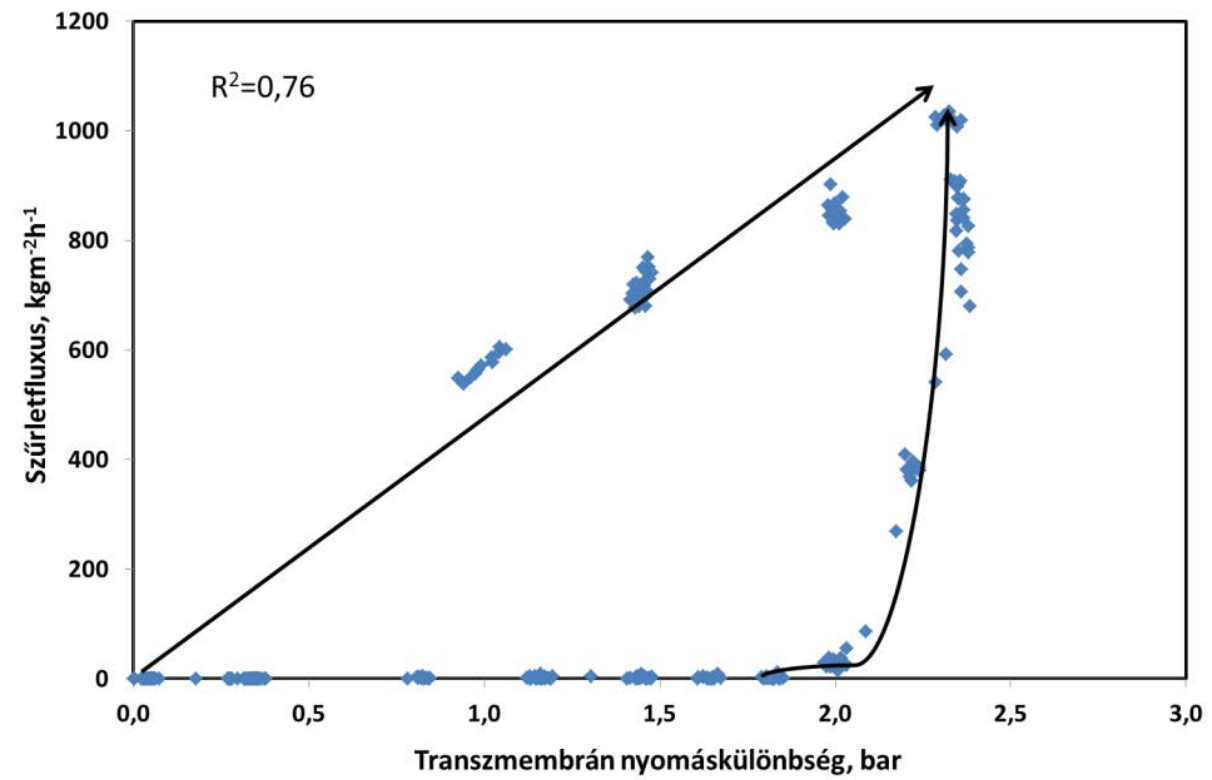

27. ábra Hiszterézis jelensége a nedvesedett lapmembrán (Durapore ${ }^{\mathrm{TM}} \mathrm{GVPH}$ ) esetében, VMD elrendezésben 


\subsubsection{DCMD elrendezés eredményei és a hiszterézis megállapítása}

A következő alfejezetben a csöves membrán modul (MD 020 CP 2N) LEP ${ }_{\mathrm{w}}$ meghatározásának eredeményeit mutatom be a 4.1.2.1. alapján, DCMD elrendezésben. Ha megfigyeljük az 28. ábrát azt vehetjük észre, hogy a transzmembrán nyomáskülönbség növelésével egy bizonyos értékig nem jelentkezik szürletáram. Ez azzal magyarázható, hogy mivel nincs a betáplálás és a desztillátum oldal között hőmérsékletkülönbség, így nem zajlik le gőz-folyadék egyensúlyon alapuló komponensátadás és mivel a még fennálló kapilláris erök miatt nem tudnak a folyadék fázisok a pórusokba behatolni, így konvektív komponensátadás sem történik.

Viszont ahogy növeltem a nyomáskülönbséget, elérkeztem egy ponthoz, ahol a betáplálási folyadékáram már képes volt benyomulni a pórusokba, ezzel elindult a konvektív szürletáram. Ahhoz, hogy részletesebben is megvizsgáljuk ezt az eseményt a 29. ábrát kell megfigyelnünk, mely felnagyítva

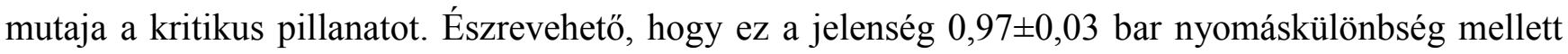
történik és a szürletáram megindulásának pillanatában $0,6 \mathrm{kgm}^{-2} \mathrm{~h}^{-1}$ konvektív fluxust eredményez, majd pedig fokozatosan emelkedik az idő és a transzmembrán nyomáskülönbség függvényében. A nedvesedés pillanatában a desztillátum oldali vezetőképesség növekedését észleltem, mely a betáplálás oldali sóoldat pórusokon való áthaladását biztosra jelezte. Visszatérve az 28. ábrára látható, hogy

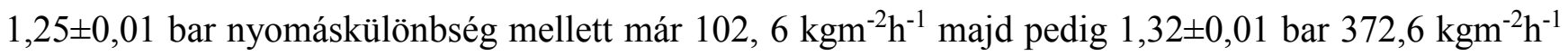
szürletfluxust tapasztaltam. Összehasonlítva az M.II. mellékletben a gyártó által közölt LEP ${ }_{w}=1,40$ bar értékkel (Mengual et al., 2004), a 0,97 bar 30\%-kal alacsonyabb értéket képvisel. Feltételezhetően az eltérés a módszerek különbségéből ered, de mivel a gyártó nem tette közzé a mérési módszert, így ezt egyértelműen kijelenteni nem lehet. 


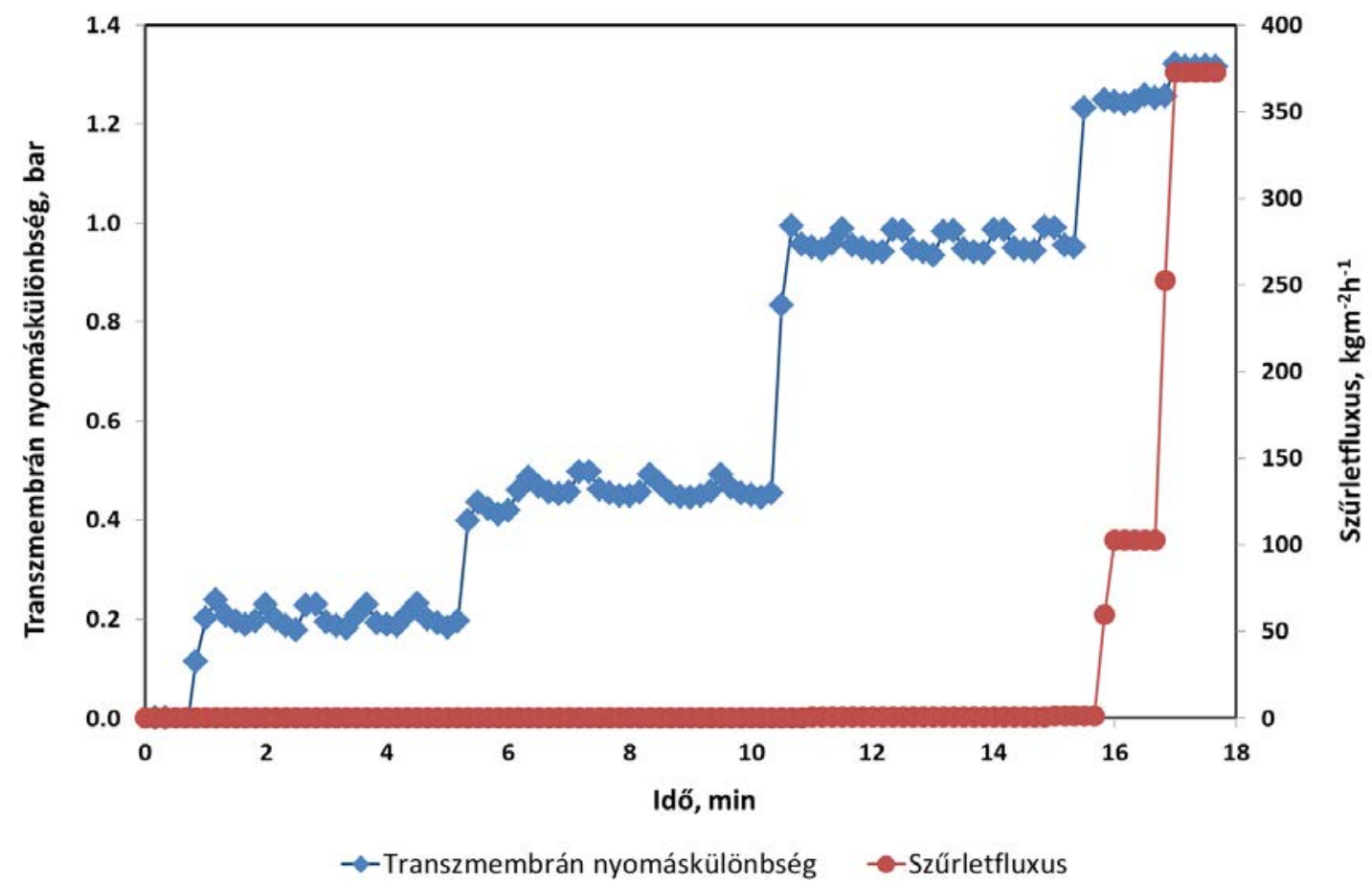

28. ábra Szürletfluxus az idő függvényében, növekvő transzmembrán nyomáskülönbség mellett csöves membrán modul esetében (MD 020 CP 2N), DCMD elrendezésben

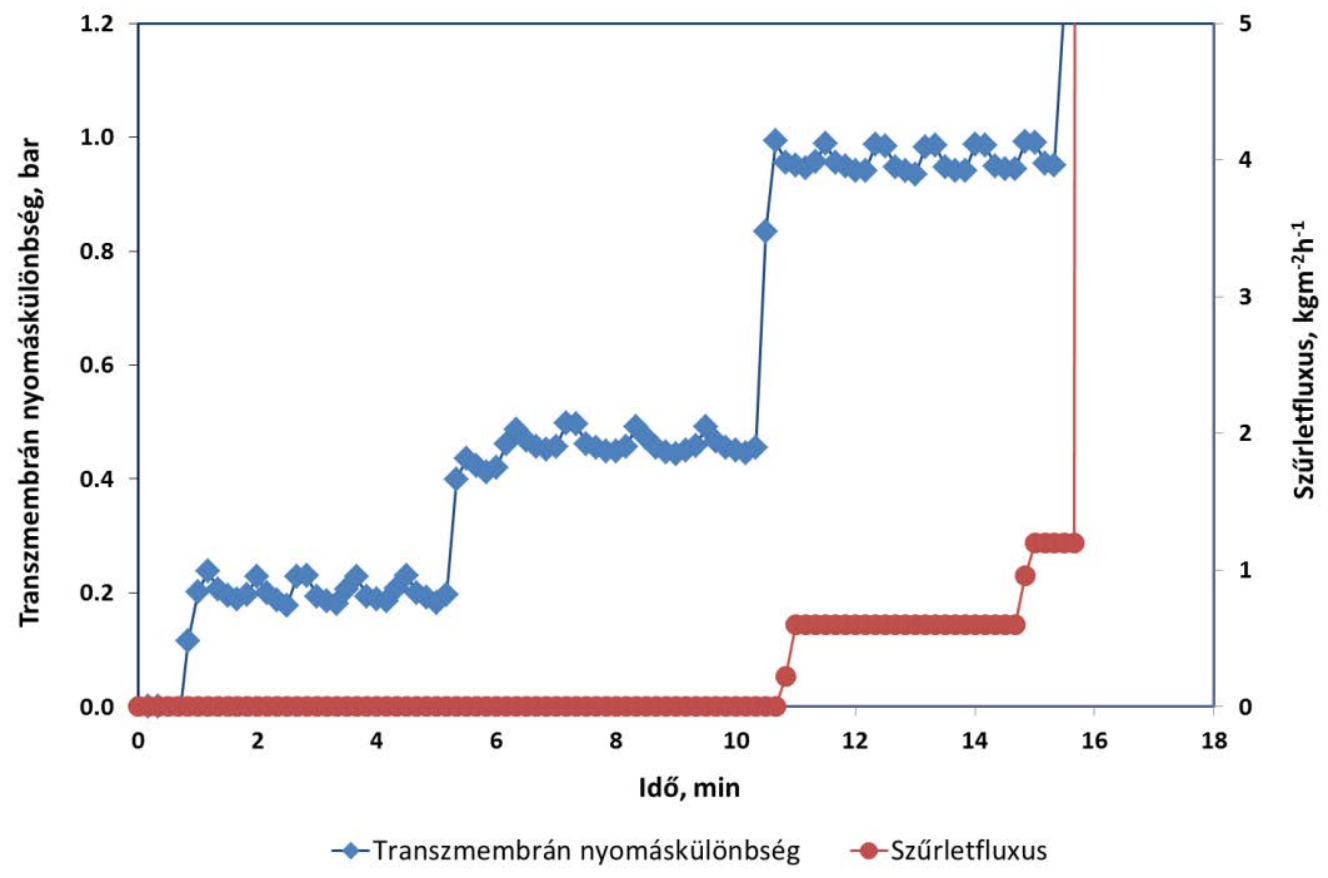

29. ábra Szürletfluxus az idö függvényében, növekvő transzmembrán nyomáskülönbség mellett csöves membrán modul esetében (MD 020 CP 2N), DCMD elrendezésben 
Az LEP ${ }_{\mathrm{w}}$ értékének meghatározását követően a hiszterézis jelenségének vizsgálatára került sor. A 30. ábra mutatja a szürletfluxsok alakulását a $\mathrm{LEP}_{\mathrm{w}}$ előtt és a nedvesedés után. A teljes nedvesedést követően lineáris összefüggést mutattam ki a vízfluxus és a transzmembrán nyomáskülönbség között. A nedvesedés után így gyakorlatilag membránszürés történik és ekkor egy egyenes illeszthető, melynek korrelációja ebben az esetben $\mathrm{R}^{2}=0,98$ értéknek adódott.

Ami szintén megfigyelhető a 30. ábrán, hogy bár az $\mathrm{LEP}_{\mathrm{w}}$ elérésének pillanatáig a rendszerben létre tudtam hozni az 1,32 $\pm 0,01$ bar nyomáskülönbséget, viszont az elárasztás után ezt a hajtóerőt már nem tudtam elérni, és így ilyen hajtóerő mellett nem tudtam megmérni az ehhez tartozó szürletfluxust. A maximális transzmembrán nyomáskülönbség, amit még létre tudtam a nedvesedés után hozni, 0,9 bar körüli érték volt, így az illesztett egyenes, mint extrapolált függvénykapcsolat érvényes a magasabb hajtóeröhöz tartozó fluxusértékek meghatározására, feltételezve a membránszürések vízfluxussal szembeni viselkedésének igazságát jelen rendszerünkre vonatkozóan is (tiszta víz a betáplálás, ahol nincs polarizációs réteg és eltömődés).

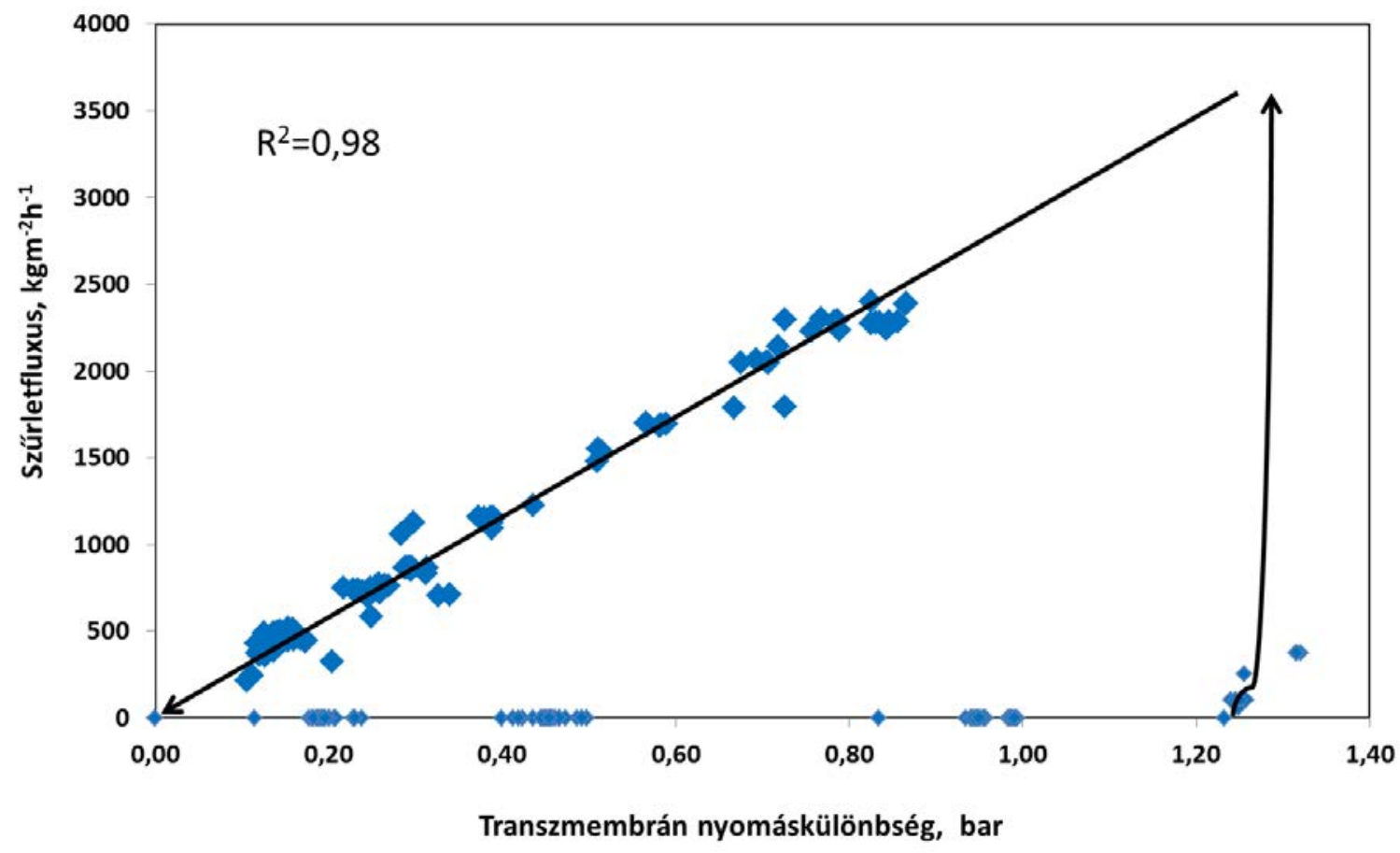

30. ábra Hiszterézis jelensége a nedvesedett csöves membrán (MD 020 CP 2N) esetében, DCMD elrendezésben 


\subsubsection{LEP ${ }_{w}$ mérési módszerek összehasonlítása}

Az LEP ${ }_{\mathrm{w}}$ meghatározására a szakirodalomban leggyakrabban a statikus módszert alkalmazzák, vagy annak különbözö variációit. Ezzel szemben az általam kifejlesztett dinamikus módszerre, módszerekre nem találtam példát. A lapmembránnal elvégzett kísérletek esetében a statikus módszerrel

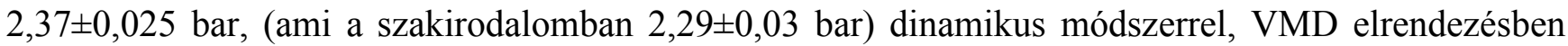
pedig 1,82 $\pm 0,02$ bar értéket kaptam. Itt már rögtön szembetünik, hogy magának a módszernek jelentős hatása van az $\mathrm{LEP}_{\mathrm{w}}$ értékére, és valós üzemeltetési körülmények között - azaz áramló fluidumok esetében - ez alacsonyabb értéknek bizonyul, mint nem áramló értinkezés mellett (23\%-kal kisebb).

Ha megvizsgáljuk ezeket az értékeket a csöves membrán modul esetében azt tapaszatljuk, hogy a szakirodalomban fellelhető 1,40 bar nedvesedési nyomás (aminek a mérési módszerét a gyártó nem

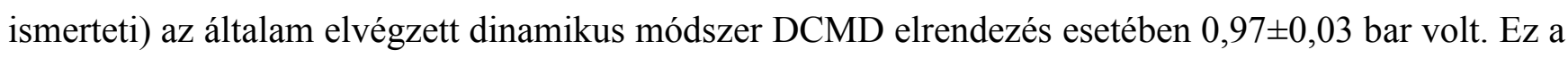
jelentős, 30\%-os eltétést jelent. Ez azt sejteti, hogy az áramlási viszonyok hatással lehetnek az $\mathrm{LEP}_{\mathrm{w}}$ értékére, és így érdemes azt a valós hidrodinamikai körülmények mellett megállapítani.

\subsubsection{Nedvesedett membránok regenerálásának eredményei}

\subsubsection{Regenerálás magas hőmérsékleten}

Először a csöves membrán modul (MD $020 \mathrm{CP} 2 \mathrm{~N}$ ) regenerálási eredményeit ismertetem, etanolos kezeléssel a 4.1.3.1. alfejezet alapján. Nem tapasztaltam nedvesedést a regenerálási eljárást követően, a DCMD elrendezében elöállított desztillátum vezetőképessége a kimutatási határérték alatt maradt (kisebb, mit $0,01 \mathrm{mScm}^{-1}$ ). Etanolos kezelés nélkül viszont, az $50^{\circ} \mathrm{C}$-os szárítás, 48 órás kezelési idő alatt sem sikerült a membránpórusok teljes regenerálása. A három párhuzamos mérés során alacsony, de egyértelmű szivárgás volt mérhető, ami $\left(0,026 \pm 0,003 \mathrm{mScm}^{-1}\right)$ desztillátum vezetőképességet eredményezett. A betáplálás $0,36 \mathrm{mScm}^{-1}$ vezetőképességéhez képest ez jóval alacsonyabb érték, de azt mutatja, hogy a regenerálás nem volt teljes, a membrán egyes részei még nem száradtak ki teljesen.

A lapmembrán (Durapore ${ }^{\mathrm{TM}} \mathrm{GVPH}$ ) regenerálása esetén a szendvicsmodulból először kivettem a nedvesedett membránt és azt helyeztem el a szárítószekrénybe $50^{\circ} \mathrm{C}-o n, 48$ órára. A kezelt membránokat ezután VMD elrendezésben teszteltem a 4.1.3.1. alfejezet ismertetett üzemeltetési paraméterek mellett. Az etanolos kezeléssel végzett szárítás sikeresenek bizonyult, mivel a kimutathatósági határérték alatti $\left(<0,01 \quad \mathrm{mScm}^{-1}\right)$ desztillátumot tudtam elóállítani a $0,36 \mathrm{mScm}^{-1}$ vezetőképességủ betáplálási sóoldatból. Etanolos kezelés nélkül a regenerálás ebben az 
esetben szintén sikeresnek bizonyult. $50^{\circ} \mathrm{C}-\mathrm{os}$, 48 órás száritás után az elöállított desztillátum vezetőképessége itt is a kimutatási határéték alatt volt $\left(<0,01 \mathrm{mScm}^{-1}\right)$.

Összegezve az eredményeket azt látjuk, hogy a csöves membrán modul esetén az etanolos kezeléssel sikerült a vizsgált 48 órás időintevallumon belül a pórusokat regenerálnom, etanolos kezelés nélkül ez sikertelennek bizonyult. Ez annak tudható be, hogy a zárt modulból, a nem megfelelő cirkuláció miatt a nedvesség (víz) nehezebben volt eltávolítható, mint az alkohol, ami könnyebben elillant. Viszont a lapmembrán esetében mind az etanolos, mind az etanol nélküli regeneráció sikeres volt. Itt csak magát a membránt helyeztem a szárítószekrénybe, melynek egész felülete folyamatosan érintkezett a friss szárító levegővel, így a szárítás sokkal hatékonyabb lehetett, mint a csöves modul esetében.

\subsubsection{Regenerálás vákuum segítségével}

A csöves membrán modul (MD $020 \mathrm{CP} 2 \mathrm{~N}$ ) vákuumos regenerálása sikertelennek bizonyult mindhárom, a 4.1.3.2 alfejezetben ismertetett, 18. ábrán bemutatott módszert alkalmazva mind etanolos kezeléssel, mind etanol nélkül. A vákuumos időt egészen 5 órára növelve, egyik vákuumos kapcsolás (betáplálás oldaról, desztillátum oldalról, mindkét odalról) sem hozott pozitív eredményt. Ennek oka az, hogy az adott vákuumérték illetve az áramlási körülmények az adott rendszerben nem voltak elegendőek a hatékony párolgáshoz, amit a csöves modul geometriája is segített. A további, vákuumszivattyú üzemeltetés pedig jelentősen megnövelheti az eljárás költségét.

A lapmembrán (Durapore ${ }^{\mathrm{TM}} \mathrm{GVPH}$ ) esetetében sikeresen tudtam a membrán regenerálni 1,5 órás vákuumozás után, etanolos kezelés nélkül, de csak a „mindkét oldalról vákuumozva” módszerrel, az ellenőrzés során a desztillátum vezetőképessége a kimutatási határérték alatt volt $\left(<0,01 \mathrm{mScm}^{-1}\right)$. Meglepő módon, viszont az etanolos kezelés nem hozott pozitív eredményt, egyik vákuum kapcsolási mód sem volt alkalmas a membrán pórusainak regenerálására, még 5 órás vákuumozási idő után sem. Ennek oka a cseppek mechanikai eltávolításában rejlhet, mivel ha a pórusok belsejéből sikeresen el is párolgott az etanol, a modul kialakítása miatt lehettek olyan helyek a modulon belül, ahol az etanol felhalmozódott, és az ellenőrzési folyamat során közvetlen éríntkezhetett ismételten a membránnal. Így eredményeim alapján a vizsgált müveleti körülmények mellett a vákuumos regenerálás esetén az etanolos kezelés nélküli módszer mutatkozott megfelelőnek. 


\subsection{Olaj-víz emulzió szétválasztása vákuum-membrándesztilláció segítségével}

Ebben az alfejezetben az olaj-víz emulzió vákuum-membrándesztillációval való szétválasztása során kapott eredményeimet kívánom bemutatni, kezdve az emulgeált olaj mennyiségének LEP értékére való hatásával, statikus és dinamikus módszerek esetében. A hiszterézis görbék bemutatását, valamint a vákuum-membrándesztillációs rendszer desztillátum fluxusának alakulását és szétválasztásának hatékonyságát különböző betáplálási összetételek mellett szintén bemutatom.

\subsubsection{LEP érték változásának vizsgálata a model $\mathrm{O} / \mathrm{V}$ emulzió összetételének függvényében, statikus módszerrel}

A 3. táblázat a statikus módszer eredményeit mutatja be, a 31. ábra pedig a membránok fizikai megjelenését mutatja kiindulási, majd elhasznált állapotban. Az eredmények azt mutatják, hogy gyakorlatilag nincs hatása az O/V emulzió összetételének az LEP értékére, attól függetlenül, hogy a vizsgálat után, a modulból kivett membránokon egyértelműen mutatkozik a lerakódott, olajos fázis.

Ez egy ellentmondásosnak tünő megfigyelés, a későbbiekben ennek okait a dinamikus módszer eredményeinek ismeretében részletesebben tárgyalom.

3. táblázat LEP értékének változása különböző betáplálás összetétel mellett, $20^{\circ} \mathrm{C}$-on

\begin{tabular}{|c|c|}
\hline Betáplált olajkoncentráció; ppm & $\underline{\text { LEP; bar }}$ \\
\hline 0 & $2,37 \pm 0,025$ \\
\hline 5 & $2,37 \pm 0,020$ \\
\hline 100 & $2,33 \pm 0,022$ \\
\hline 1000 & $2,29 \pm 0,010$ \\
\hline 3200 & $2,34 \pm 0,024$ \\
\hline
\end{tabular}



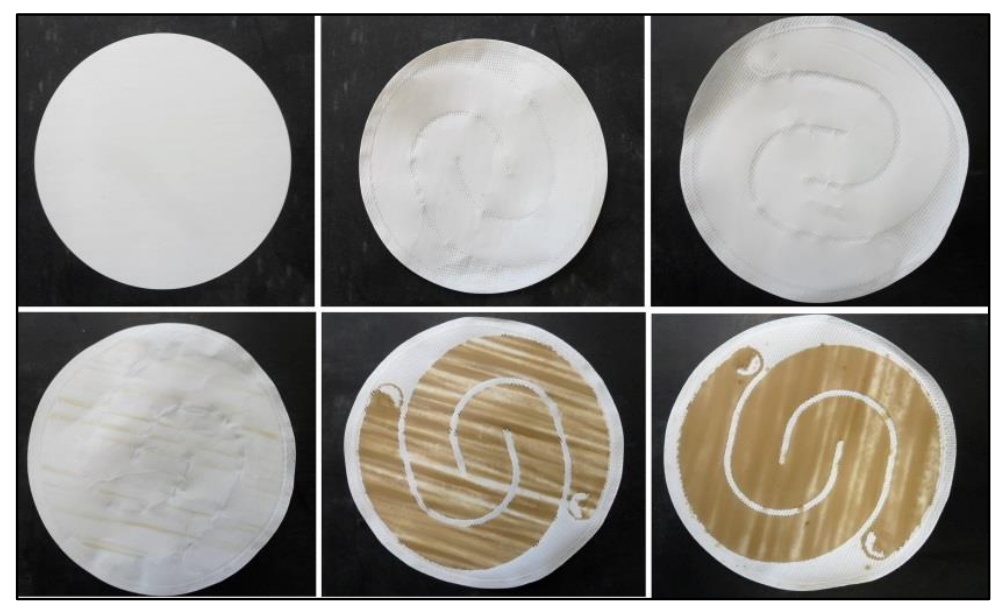

31. ábra A membrán felületének változása, olajlerakódás statikus LEP méréssel (bal felső sarokban az új, nem használt, fent középen a 0 ppm, jobb fennt 5 ppm, bal lent 100 ppm, bal közép 1000 ppm, jobb lennt 3200 ppm olajkoncentráció mellett)

\subsubsection{LEP érték változásának vizsgálata a model $\mathrm{O} / \mathrm{V}$ oldat összetételének függvényében, dinamikus módszerrel}

A 4. táblázat összegzi a dinamikus módszer eredményeit VMD konfigurációban, a 32. ábra pedig az elhasznált membránok olajos fázissal való érintkezési felületét szemlélteti. Ezzel a módszerrel a pórusok nedvesedése sokkal alacsonyabb transzmembrán nyomáskülönség mellett megtörtént. Látható, hogy alacsonyabb olajkoncentrációig nincs kimutatható LEP változás ( $0 ; 35$ ppm - 2,00 bar), viszont 200 ppm olajtartalom mellett már jelentős csökkenés volt érzékelhetö, továbbá 250 ppm-nél spontán nedvesedés következett be.

4. táblázat LEP értéke dinamikus módszerrel mérve, különböző olajkoncentrációk mellett

\begin{tabular}{|c|c|c|c|}
\hline$\frac{\text { Betáplált }}{\frac{\text { olajkoncentráció; }}{\text { ppm }}}$ & $\frac{\text { Vákuumoldali nyomás; }}{\underline{\operatorname{bar}(\mathrm{g})}}$ & $\begin{array}{l}\text { Betáplálás oldai } \\
\underline{\text { nyomás; } \operatorname{bar}(\mathrm{g})}\end{array}$ & $\underline{\text { LEP; bar }}$ \\
\hline 0 & $-0,93(70$ mbar(a)) & 1,07 & 2,00 \\
\hline 35 & $-0,92(80$ mbar(a)) & 1,08 & 2,00 \\
\hline 200 & $-0,93(70$ mbar(a)) & 0,50 & 1,43 \\
\hline 250 & --- & 0,21 & $\begin{array}{c}\text { Spontán } \\
\text { nedvesedés }(0,21)\end{array}$ \\
\hline
\end{tabular}



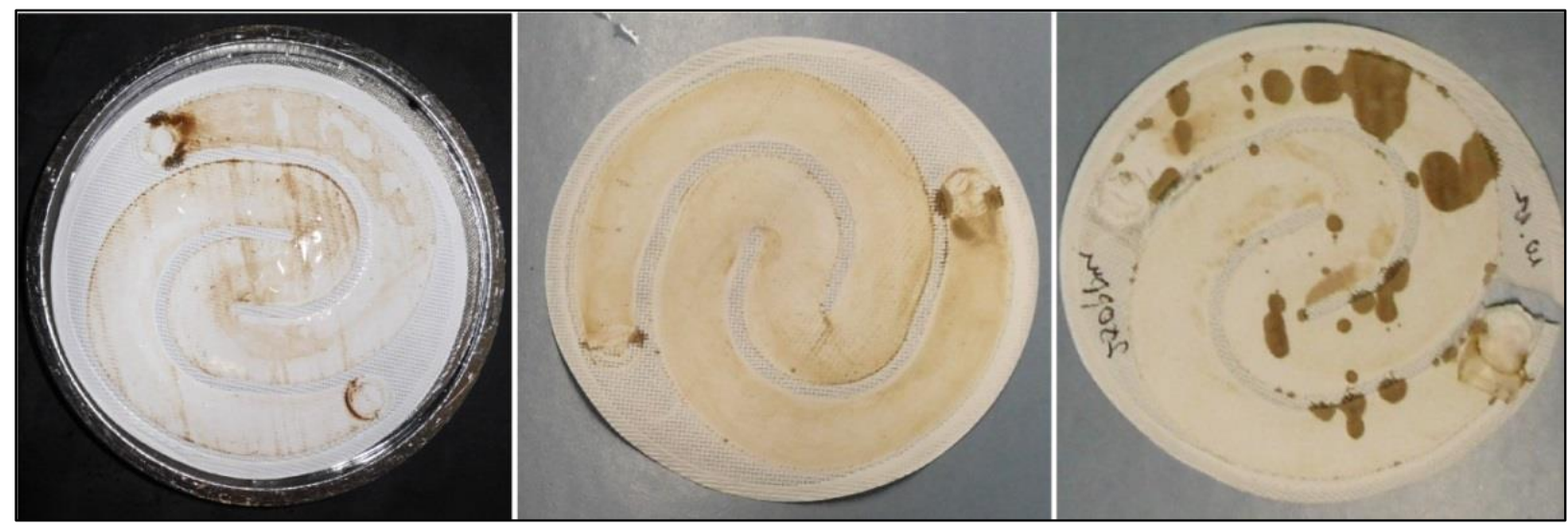

32. ábra A membrán felületének változása, olajlerakódás dinamikus méréssel (35 ppm, 200 ppm, 250 ppm)

A 32. ábrán látható, hogy 35 ppm-nél és 200 ppm-nél a modul belépési és kilépési oldalán találhatunk kifejezetten „olajos” foltokat, területeket, míg a 250 ppm-nél az egész áramlási csatorna mentén jelentkeznek ilyen foltok. Összehasonlítva a 31-32. ábrákat látható, hogy amennyiben a nyomáskülönbség a nyugvó emulzióra gyakorlatilag „felülről”, egy oldalról a membránra merőlegesen van kifejtve, 1000 ppm-ig alig észrevehető lerakódásokat okoz. Abban az esetben, amikor közeg áramlik és a nyomáskülönbég vákuum segítségével van létrehozva, a belépési és kilépési pontnál is megjelennek erősen szennyződött területek. A legjelentősebb a spontán nedvesedés különbsége, ami statikus módszernél még 3200 ppm esetében sem jelent meg.

Mivel a dinamikus mérési módszer gyakorlatilag a valóságos körülményeket szimulálja, így az itt kapott eredményeket fogadtam el, mint valós LEP értékek, és az O/V emulziók esetében a statikus módszer alkalmazását nem tekintem megfelelőnek. A módszerek közötti különbségek már az előző fejezetben is megjelentek, ott is a dinamikus módszerek eredményeztek alacsonyabb értékeket. Ezek alapján egyértelmüen kijelenthető, hogy az áramló emulzió a pórusokkal szemben máshogy viselkedik, mint a nyugvó, így ez az LEP értéke is hatással van.

A 33. és 34. ábrák a hiszterézis jelenségét mutatják 35 ppm és 200 ppm olajtartalom esetében. A 250 ppm esetében nem tudtam ilyen hiszteréztis görbét kimérni, mivel az emulzió a membránnal érintkezve azonnal átnedvesítette a membránt (0,21 bar nyomás jött létre csak az emulzió áramoltatása miatt). Mindkét esetben látszik, hogy a nedvesedés után a jelenség D’Arcy tövénye szerint zajlik, a lineáris korreláció mértékét jelző $\mathrm{R}^{2}$ érték nagyon magas. 
Ha szemügyre vesszük a 33. ábrát látható, hogy a nedvesedés nagyon meredeken következik be, egészen 2,00 bar-ig gyakorlatilag nem történik nedvesedés, viszont utána nagyon gyorsan átnedvesedik az összes pórus. A 34. ábrán viszont azt figyelhetjük meg, hogy 200 ppm olajkoncentráció mellett a nedvesedés fokozatosan történik, a növekvő transzmembrán nyomáskülönséggel egyre több-és több pórus nedvesedik, ezáltal korábban, de „lassabban” romlik a desztillátum minősége.

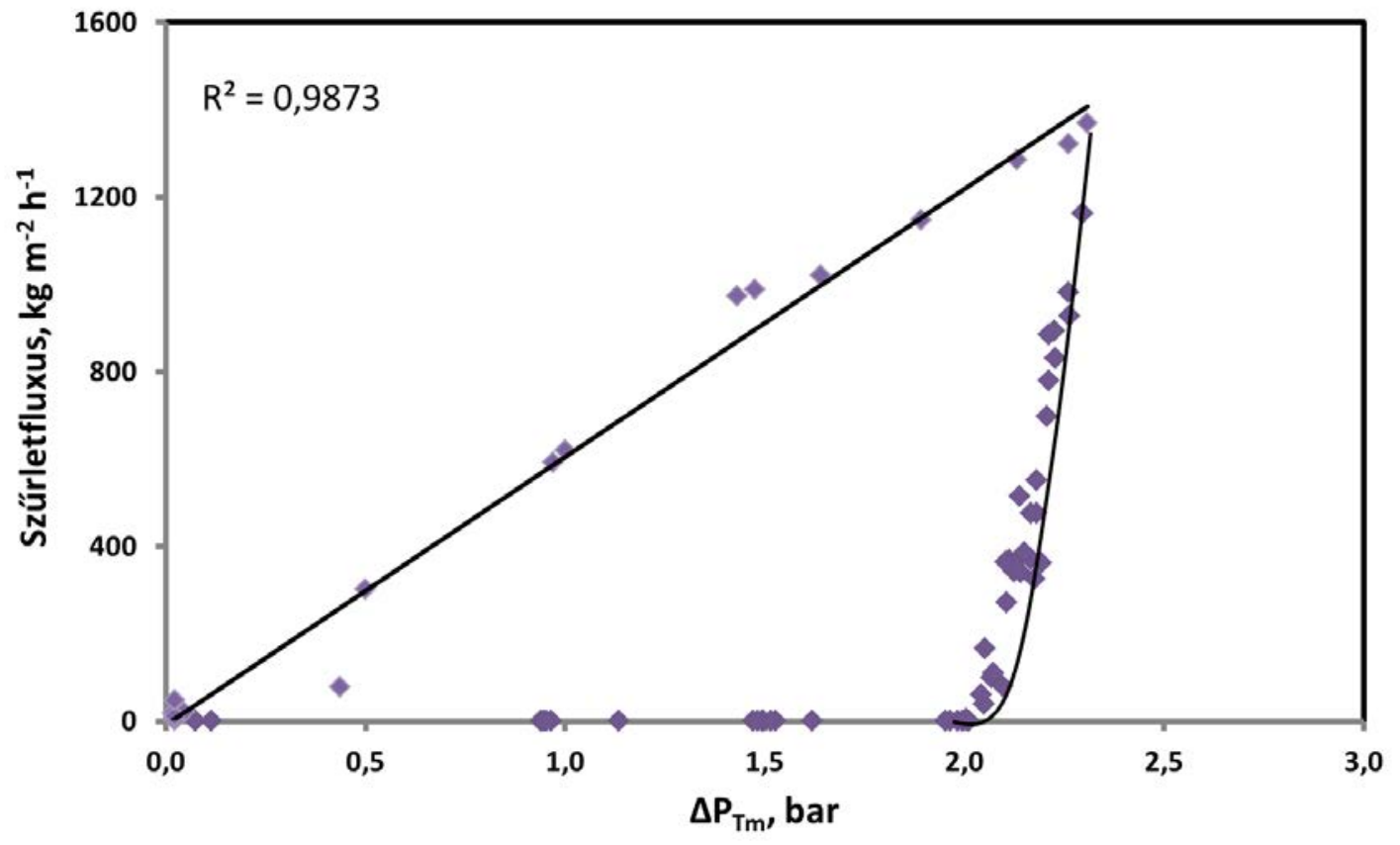

33. ábra Hiszterézis jelensége 35 ppm betáplálás mellett 


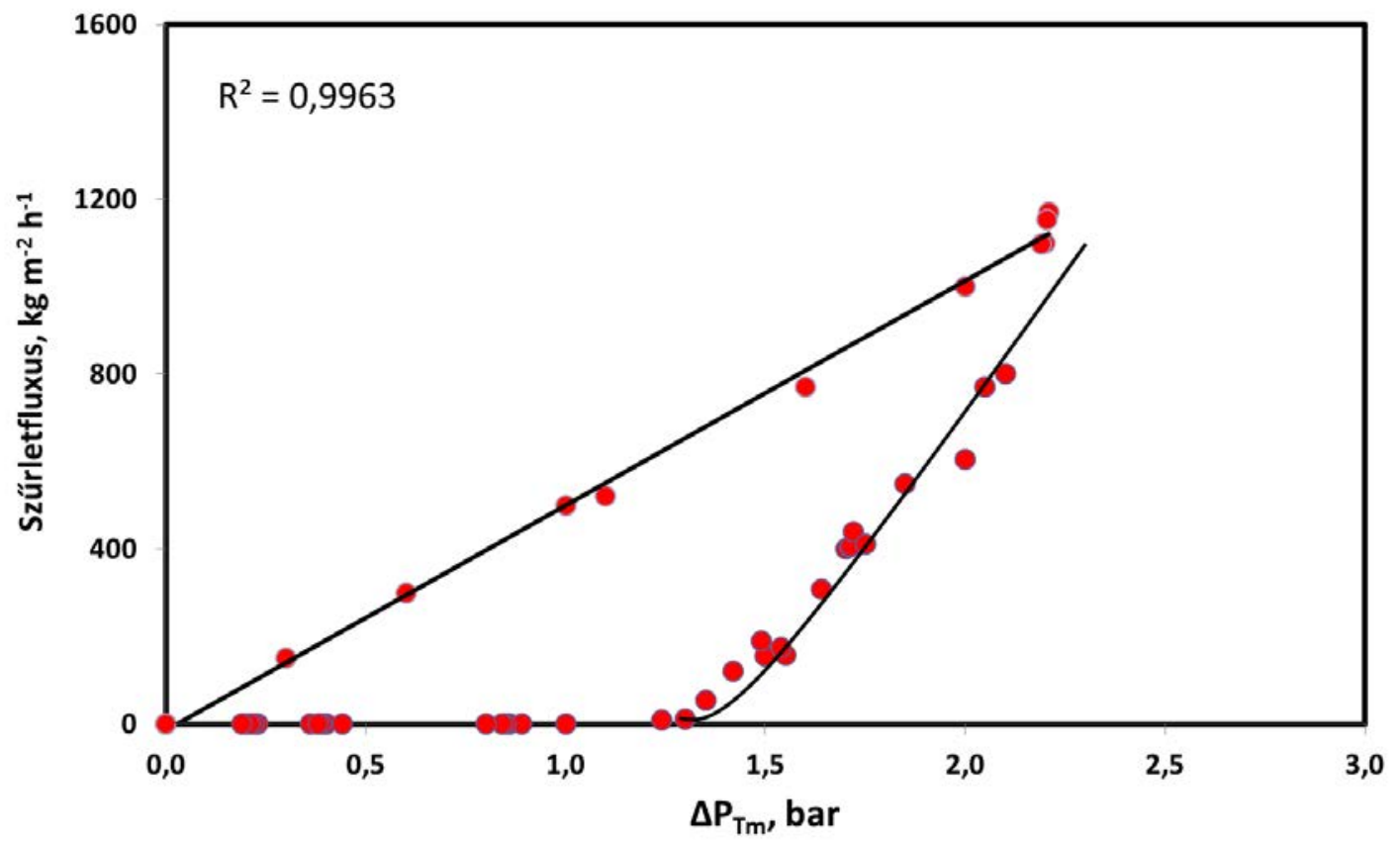

34. ábra Hiszterézis jelensége 200 ppm betáplálás mellett

\subsubsection{O/V emulzió szétválasztásának eredményei vákuum-membrándesztillációs berendezéssel}

A következő alfejezetben bemutatom a VMD elrendezésben elvégzett $\mathrm{O} / \mathrm{V}$ emulzió szétválasztásának eredményeit. A 35. ábra mutatja a különböző olajtartalom mellett mért desztilátum fluxus értékeket, 200 ppm-ig bezárólag. E fölött az érték fölött a membrán spontán nedvesedett, így ekkor már a membrándesztilláció nem volt megvalósítható.

Az 35. ábrán jól megfigyelehető, hogy a növekvő olajkoncentráció a vizsgált tartományban gyakorlatilag nem volt hatással a desztillátum fluxus értékére, melyet $5 \mathrm{kgm}^{-2} \mathrm{~h}^{-1}$ körüli értéknek határoztam meg. Ez az érték az irodalmonban fellelhető, hasonló műveleti paraméterek mellett elvégzett vákuum-membrándesztillációs kísérletek eredményeivel összehangban van (JANSEN et al. 2013; CRISCUOLI et al. 2012, GRYTA és KARAKULSKI, 1999). A vizsgált 5 órás intervallumban nem történt nedvesedés. A 36. ábra mutatja a kiindulási emulzió és a kapott termékek fizikai megjelenését. Látható, hogy gyakorlatilag tiszta, tükrös desztillátumot nyertem a VMD müvelettel.

A kapott eredményeket összehasonlítva GRYTA és KARAKULSKI (1999) közleményével, azokkal csak részben egyeznek meg. Ebben a közleményben a fluxusértékek $60^{\circ} \mathrm{C}$ betáplálási hőmérséklet mellett, 0-1000 ppm olajkoncentráció tartományban vizsgálva csökkenő fluxusértékeket 
mutatnak, a nedvesedés jelensége csak 1000 ppm-nél jelentkezett. Az általam vizsgált esetben már 250 ppm koncentráció mellett megtörtént a nedvesedés, viszont eddig a pontig nem történt desztillátum fluxus csökkenés. Fontos megjegyezni viszont, hogy DCMD konfigurációt alkalmaztak, $20^{\circ} \mathrm{C}$-os permeátum oldali hőmérséklettel, és kapillárcsöves polipropilén membránnal, melynek átlagos pórusátmérője 0,2 $\mu \mathrm{m}$ volt. Lamináris áramlási körülmények mellett üzemeltették a rendszert (A Reszámot, a publikációban megadott adatok alapján 1800-ra becsültem). Továbbá azt is fontos megemlíteni, hogy a szerzők nem vizsgálták az emulgeált olajcseppek méreteloszlását, aminek az ismerete pedig meghatározó az eredmények összehasonlítása céljából.

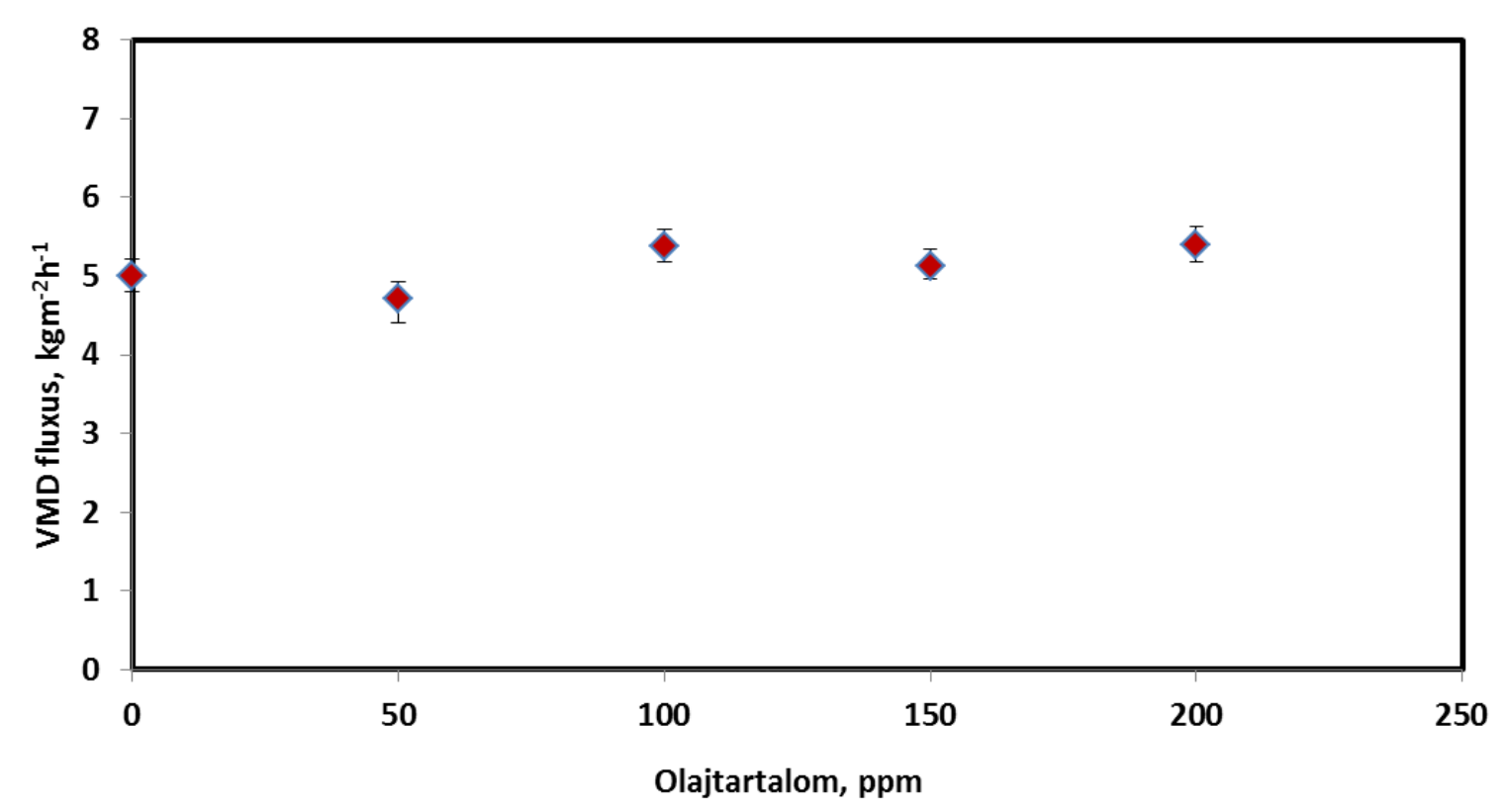

35. ábra Olajtartalom hatása a VMD fluxusára $\left(\mathrm{T}_{\text {betáp }}=50^{\circ} \mathrm{C}, \mathrm{Re}=900 \mathrm{p}_{\text {vákuum }}=70 \mathrm{mbar}(\mathrm{a})\right)$

A 5. táblázat a betáplálás, a desztillátum és a retentátum teljes szerves komponens (TOC) értékeit mutatja, a 6. táblázat pedig a különbözö összetételü betáplálás és retentátum részecskeméreteloszlását, melyet a 38. ábra szemléletet a teljes eloszlásokkal együtt. A 5. táblázatban feltüntetet értékek alapján megállapítható, hogy minden esetben nagyobb, mint 90\%-ban visszatartotta a membrán az olajos fázist. Az is megfigyelhető, hogy a retentátumban szignifikánsan alacsonybb koncentrációt mértem a kiindulási értéhez képest. Ez a 37. ábrán is egyértelmüen mutatkozik - a membrán felületére, bizonyos esetekben a pórusokba is beleragadt az olaj. A 6. táblázat értékei pedig azt mutatják, hogy a retentátumban a kiindulási emulzióhoz képest azt átlagos részecskeméret csökkent, tehát a nagyobb méretű szemcsék könnyebben rakódnak ki a membrán felületére. Összességében megállapható, hogy a 
VMD konfiguráció alkalmas az $\mathrm{O} / \mathrm{V}$ emulzió szétválasztására, de az adott műveleti körülmények mellett egy spontán nedvesedés tapasztalható 250 ppm olajtartalom mellett.

5. táblázat VMD elrendezés $\mathrm{O} / \mathrm{V}$ emulzió szétválasztása során kapott termékek teljes szerves komponens (TOC) értékei

\begin{tabular}{|c|c|c|c|c|}
\hline & $\mathbf{5 0} \mathbf{~ p p m}$ & $\mathbf{1 0 0} \mathbf{p p m}$ & $\mathbf{1 5 0} \mathbf{p p m}$ & $\mathbf{2 0 0} \mathbf{~ p p m}$ \\
\hline Betáplálás; ppm & 49,7 & 108,5 & 147,8 & 192,5 \\
\hline Retentátum; ppm & 20,7 & 75,1 & 74,0 & 73,3 \\
\hline Desztillátum; ppm & 3,3 & 4,0 & 4,7 & 5,8 \\
\hline Visszatartás; \% & 93,4 & 96,3 & 96,8 & 97,0 \\
\hline
\end{tabular}

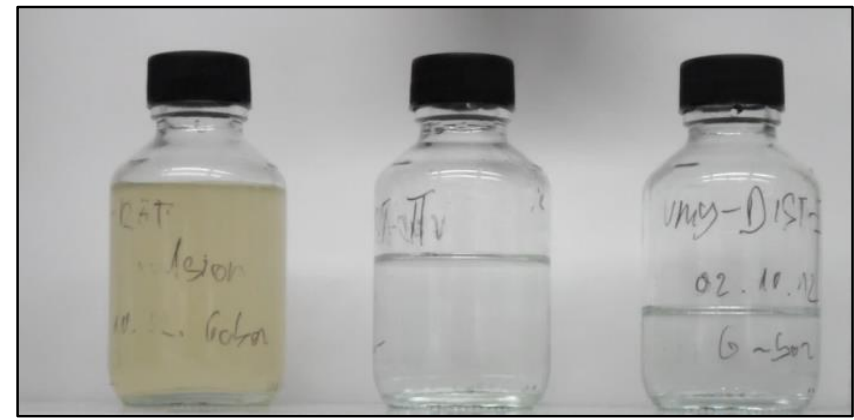

36. ábra Retentátum és desztillátum 100 ppm olajkoncentráció mellett, VMD konfigurációval
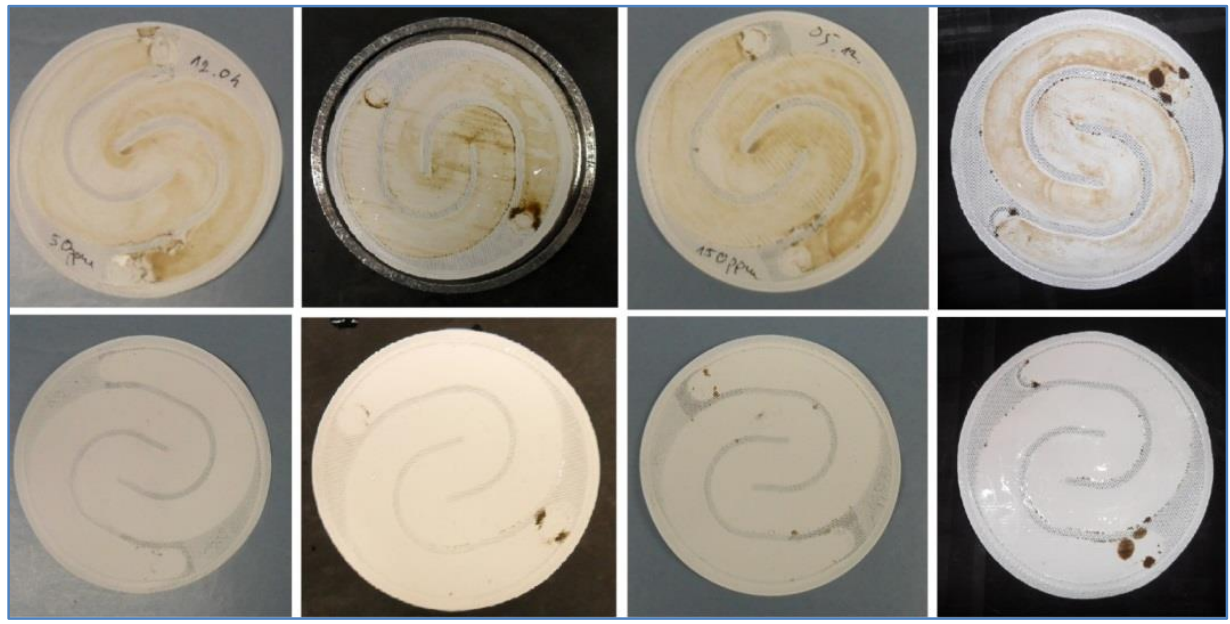

37. ábra Használt membránok retentátum és desztillátum oldalai (50-200ppm, balról jobbra, fent a retentátum oldal, lent a desztillátum oldali membránfelületek) 
6. táblázat Diszpergált olajcseppek átmérőjének eloszlása

\begin{tabular}{|c|c|c|c|c|c|c|c|c|}
\hline & \multicolumn{2}{|c|}{$\mathbf{5 0} \mathbf{p p m}$} & \multicolumn{2}{c|}{ 100 ppm } & \multicolumn{2}{c|}{ 150 ppm } & \multicolumn{2}{c|}{ 200 ppm } \\
\hline & Betáp. & Ret. & Betáp. & Ret. & Betáp. & Ret. & Betáp. & Ret. \\
\hline D (v, 0,1) $(\boldsymbol{\mu m})$ & 0,4 & 0,3 & 0,3 & 0,2 & 0,4 & 0,3 & 0,3 & 0,3 \\
\hline $\mathbf{D}(\mathbf{v}, \mathbf{0 , 5})(\boldsymbol{\mu m})$ & 1,5 & 0,9 & 1,1 & 0,8 & 1,1 & 0,8 & 1,0 & 0,8 \\
\hline $\mathbf{D}(\mathbf{v}, \mathbf{0 , 9})(\boldsymbol{\mu m})$ & 6,2 & 2,4 & 2,8 & 2,1 & 2,8 & 2,0 & 2,3 & 1,9 \\
\hline
\end{tabular}

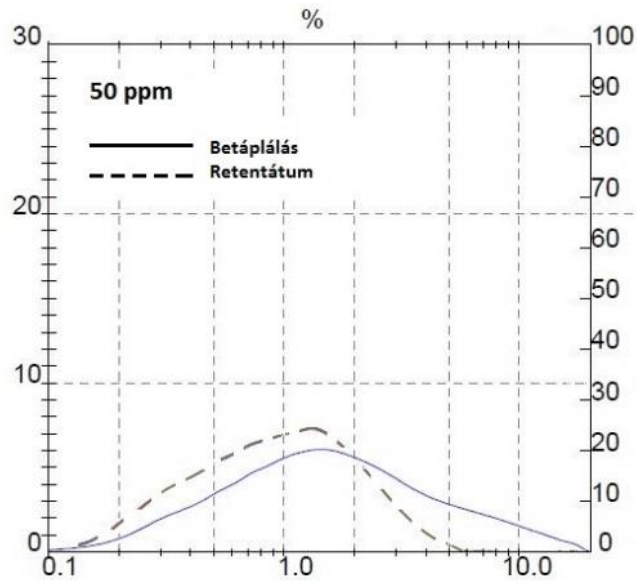

Részecske átmérője $(\mu \mathrm{m}$.)

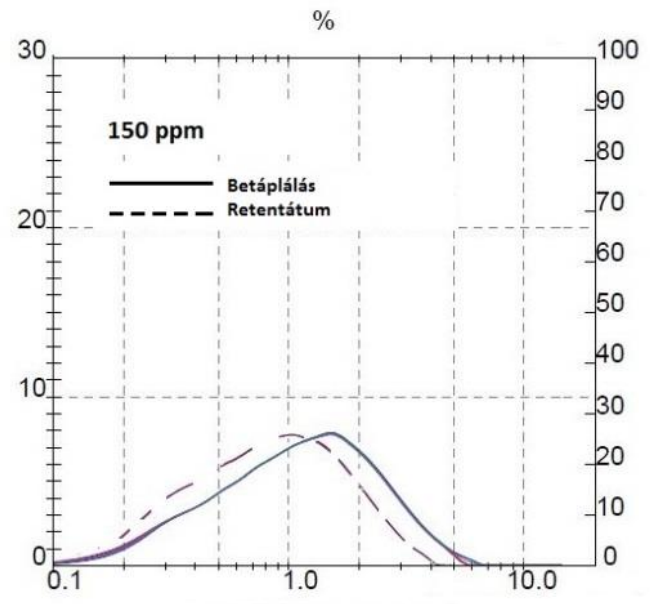

Részecske átmérője $(\mu \mathrm{m}$.)

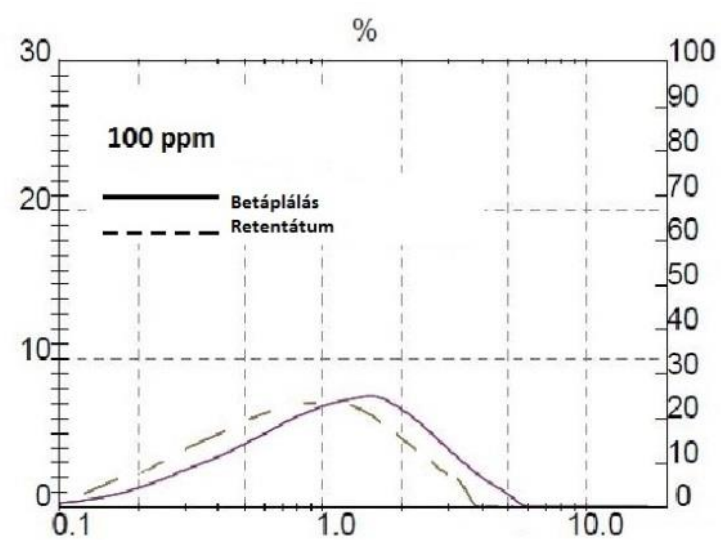

Részecske átmérője ( $\mu \mathrm{m}$.)

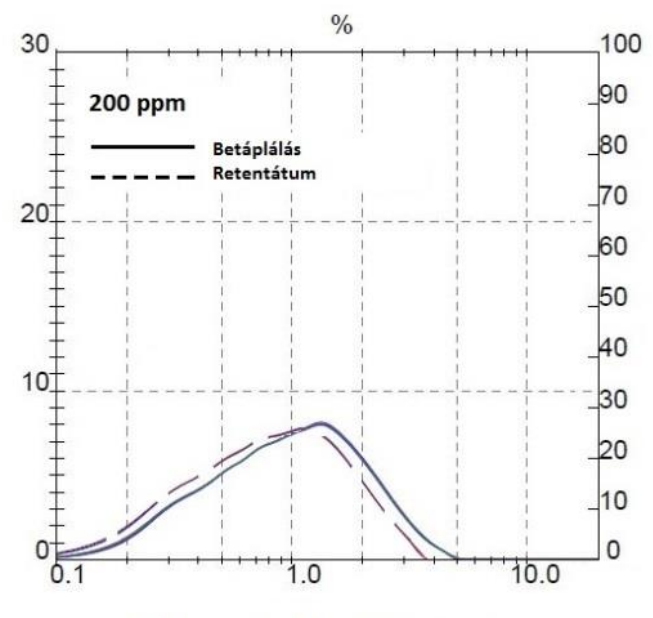

Részecske átmérője $(\mu \mathrm{m}$.

38. ábra A VMD művelet betáplálásának, majd pedig retentátumának a részecskeméret-eloszlása 


\subsection{A többlépcsős membrános eljárás zsályahatóanyagok kinyerésének eredményei}

A következő alfejezetben a zsályakivonat koncentrálásához kapcsolódó művelettani és kémiai analízis során kapott eredményeimet ismertetem. A kiindulási $15 \mathrm{~L}, 0,9 \mathrm{~m} / \mathrm{m} \%$-os zsályakivonat a koncentrálási folyamat eredményeképpen $0,28 \mathrm{~L}, 32,4 \mathrm{~m} / \mathrm{m} \%$-os értékre koncentrálódott, mely folyamat sürítési aránya $\mathrm{VRF}=53,37$.

\subsubsection{Zsályakivonat mikroszürésének eredményei}

Az 39. ábra szemlélteti a mikroszürés szürletfluxusát desztillált víz és a zsályakivonat szürése során. Jól látható a várt lineáris összefüggés a szürletfluxus és a transzmembrán nyomáskülönbség között, desztillált víz esetére. A membrán permeabilitási állandója $311,55 \mathrm{Lm}^{-2} \mathrm{~h}^{-1} \mathrm{bar}^{-1}$, az illesztett egyenes $\mathrm{R}^{2}=0,9926$.

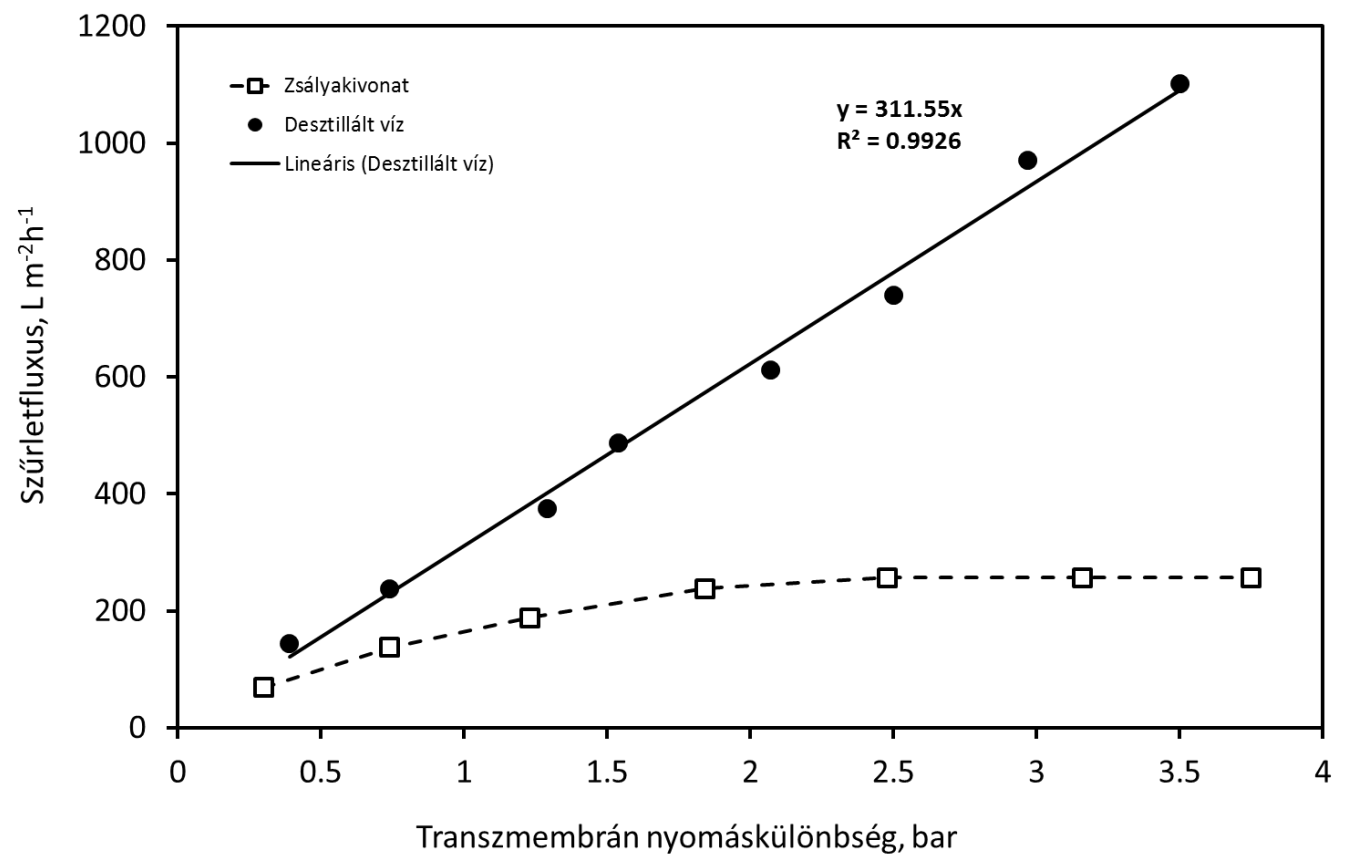

39. ábra Desztillált víz és a zsályakivonat mikroszürése során fellépő fluxusértékek a transzmembrán nyomáskülönbség függvényében $\left(\mathrm{T}=30^{\circ} \mathrm{C}, \mathrm{Q}_{\mathrm{rec}}=500 \mathrm{Lh}^{-1}\right)$

A zsályakivonat mikroszürésének görbéjéböl megállapítható az ún. kritikus fluxus, amelyet $237 \mathrm{~L} \mathrm{~m}^{-2} \mathrm{~h}^{-1}$ értéknek határoztam meg, 1,84 bar transzmembrán nyomáskülönbség mellett. A 39. ábrán a hajtóerő növelés további hatását figyelve észrevehető, hogy egy bizonyos érték fölött gyakorlatilag nem tapasztalható szürletfluxus növekedés. A limitáló fluxus $256 \mathrm{~L} \mathrm{~m}^{-2} \mathrm{~h}^{-1}$, a nyomáskülönbség pedig 2,5 bar volt. 
$\mathrm{Az}$ 40. ábra mutatja a zsályakivonat mikroszürése során fellépő fluxuscsökkenést a sürítési arány függvényében. Összességében a 15 L zsályakivonat-szürés elvégzése 30 percig tartott és 14 L tükrösített szürletet eredményezett, $0,9 \mathrm{~m} / \mathrm{m} \%$ szárazanyag-tartalommal. Ez a kiindulási értékkel megegyezik, ami mutatja, hogy a 0,45 $\mu \mathrm{m}$-es membrán gyakorlatilag csak a szuszpendált szilárd részeket és az esetleges mikroorganizmusokat távolította el, amit a refraktométer nem tudott mérni. Ha megfigyeljük az ábrát, láthatjuk, hogy a kritikus transzmembrán nyomáskülönbség mellett is érzékelhető fluxuscsökkenés, ami a membrán eltömődéséböl következik. Ez, az ábra értékei alaján, 15\%-os fluxuscsökkenést jelentett a folyamat végére.

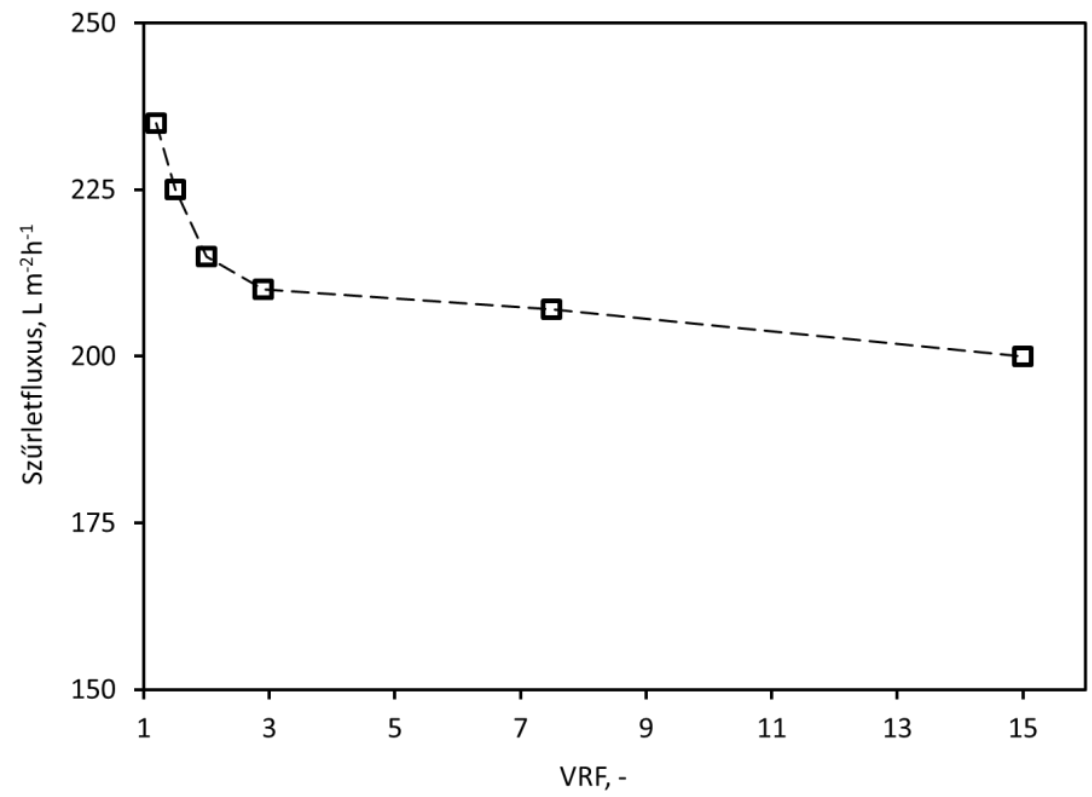

40. ábra Zsályakivonat mikroszürése során fellépő szürletfluxus csökkenés a növekvő sürítési arány

$$
\text { függvényében }\left(\mathrm{T}=30^{\circ} \mathrm{C}, \mathrm{Q}_{\mathrm{rec}}=500 \mathrm{Lh}^{-1}, \mathrm{TMP}=1,84 \text { bar }\right)
$$

\subsubsection{Zsályakivonat fordított ozmózisos elősürítésének eredményei}

A 41. ábra szemlélteti a fordított ozmósis alkalmazásának eredményeit a zsályakivonat koncentrálására vonatkozóan. A membrán permeabilitási tényező értéke $1,992 \mathrm{Lm}^{-2} \mathrm{~h}^{-1}$ bar $^{-1}$ volt $\left(\mathrm{R}^{2}=0,9685\right)$. Ugyanez a paraméter a zsályakivonat esetében $0,6382 \mathrm{Lm}^{-2} \mathrm{~h}^{-1} \mathrm{bar}^{-1}\left(\mathrm{R}^{2}=0,9906\right)$. Az eltérés a membrán eltömődésével és a koncentráció polarizáció jelenségével magyarázható.

A kritikus és limitáló értékek megállapítása nem volt megvalósítható, ezek az értékek az ebben a rendszerben előállítható legnagyobb transzmembrán nyomáskülönbség felett lehetnek, ami viszont már nem tekinthető gazdaságos üzemeltetésnek ( $>50$ bar). A legmagasabb elért fluxusérték $35 \mathrm{Lm}^{-2} \mathrm{~h}^{-1}$ volt, 50 bar transzemembrán nyomáskülönbség mellett. 


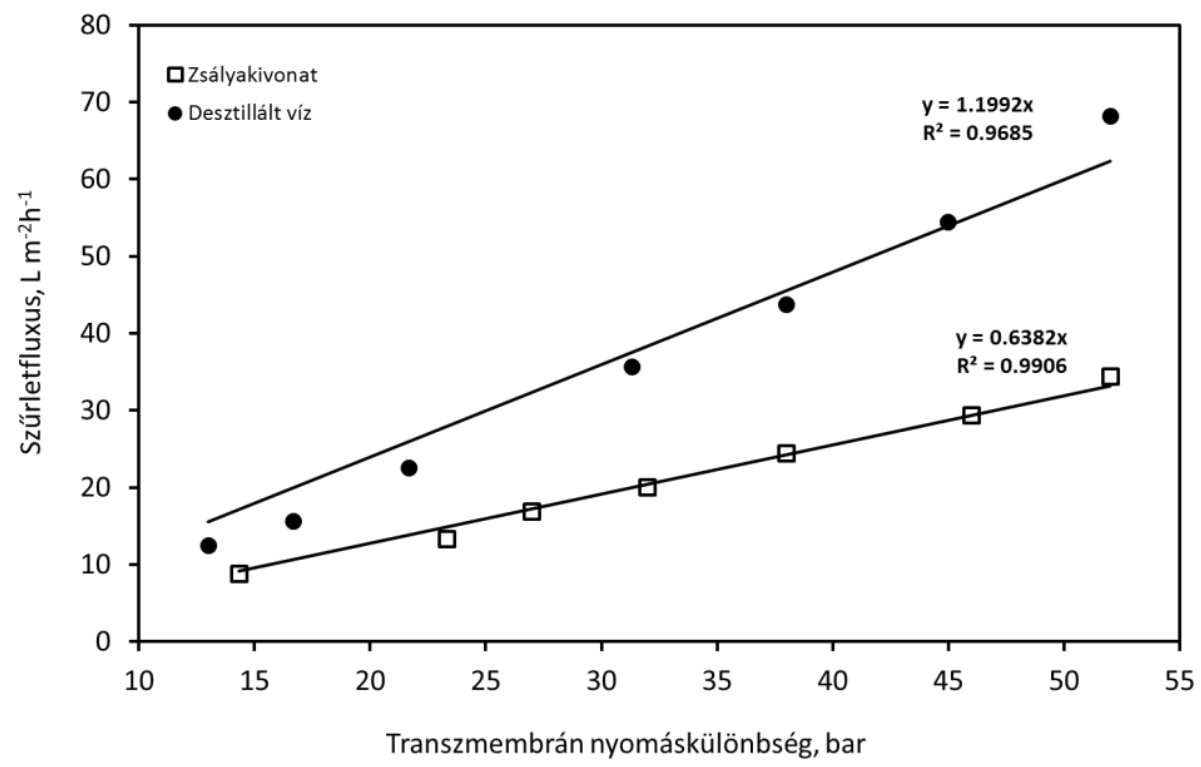

41. ábra Zsályakivonat elősürítése fordított ozmózissal, különböző transzemembrán nyomáskülönbségek mellett $\left(\mathrm{T}=30^{\circ} \mathrm{C}, \mathrm{Q}_{\mathrm{rec}}=600 \mathrm{Lh}^{-1}\right)$

A 42. ábra mutatja a szürletfluxus változását és a szárazanyag-tartalom változását a sürítési arány függvényében.

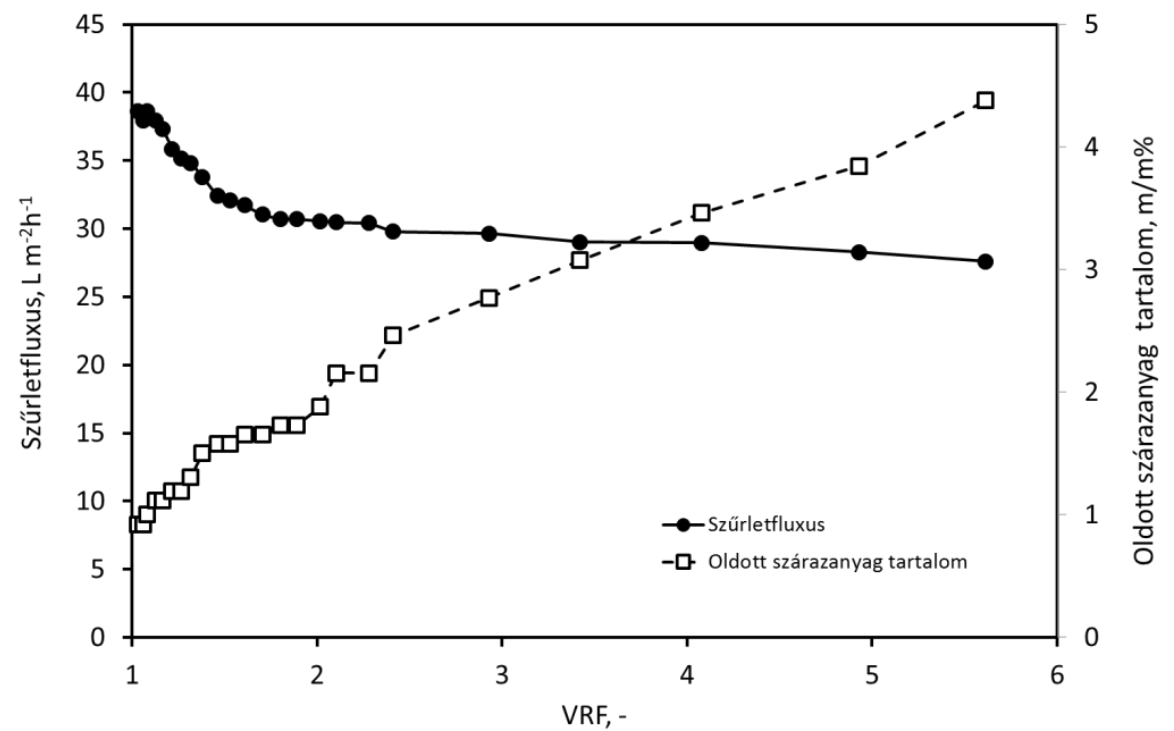

42. ábra Zsályakivonat szürletfluxusának és szárazanyag-tartalmának alakulása a sürítési arány függvényében $\left(\mathrm{T}=30^{\circ} \mathrm{C}, \mathrm{Q}_{\mathrm{rec}}=600 \mathrm{Lh}^{-1}, \mathrm{TMP}=50 \mathrm{bar}\right)$ 
$\mathrm{Az}$ 42. ábra azt mutatja, hogy a sürítési folyamat elörehaladásával a fluxus folyamatosan

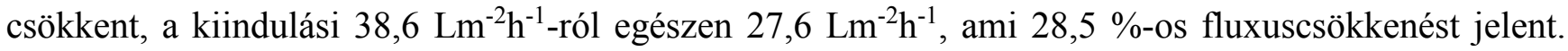
Ennek folyamán a kiindulási $0,9 \mathrm{~m} / \mathrm{m} \%$-ról a szárazanyag tartalom 4,38 $\mathrm{mm}^{-1} \%$ ra emelkedett, és ennek a lépésenk a sürítési aránya így $\mathrm{VRF}=5,61$.

\subsubsection{Zsályakivonat végsürítése ozmotikus desztillációval}

A mikroszüréssel kezelt és fordított ozmózissal elősűrített zsályakivonat végsürítését ozmotikus desztillációval valósítottam meg. A 43. ábra mutatja a folyamatra jellemező fluxusértékeket, a sürítési arány függvényében. A kiindulási, 2,25 $\mathrm{kgm}^{-2} \mathrm{~h}^{-1}$ desztillátum fluxus értéke a folyamat végére lecsökkent egészen $1,71 \mathrm{kgm}^{-2} \mathrm{~h}^{-1}$-ra. Ennek oka az, hogy a folyamatot szakaszosan hajtottam végre, így az ozmotikus oldat kiindulási koncentráció a folymat előrehaladtával folyamatosan csökkent, és a zsályakivonaté pedig folyamatosan nőtt. Ennek következtében a hajtóőerő (az oldatok membránpórusok bejáratánál kialakuló gőznyomáskülönbsége) folyamatosan csökkent.

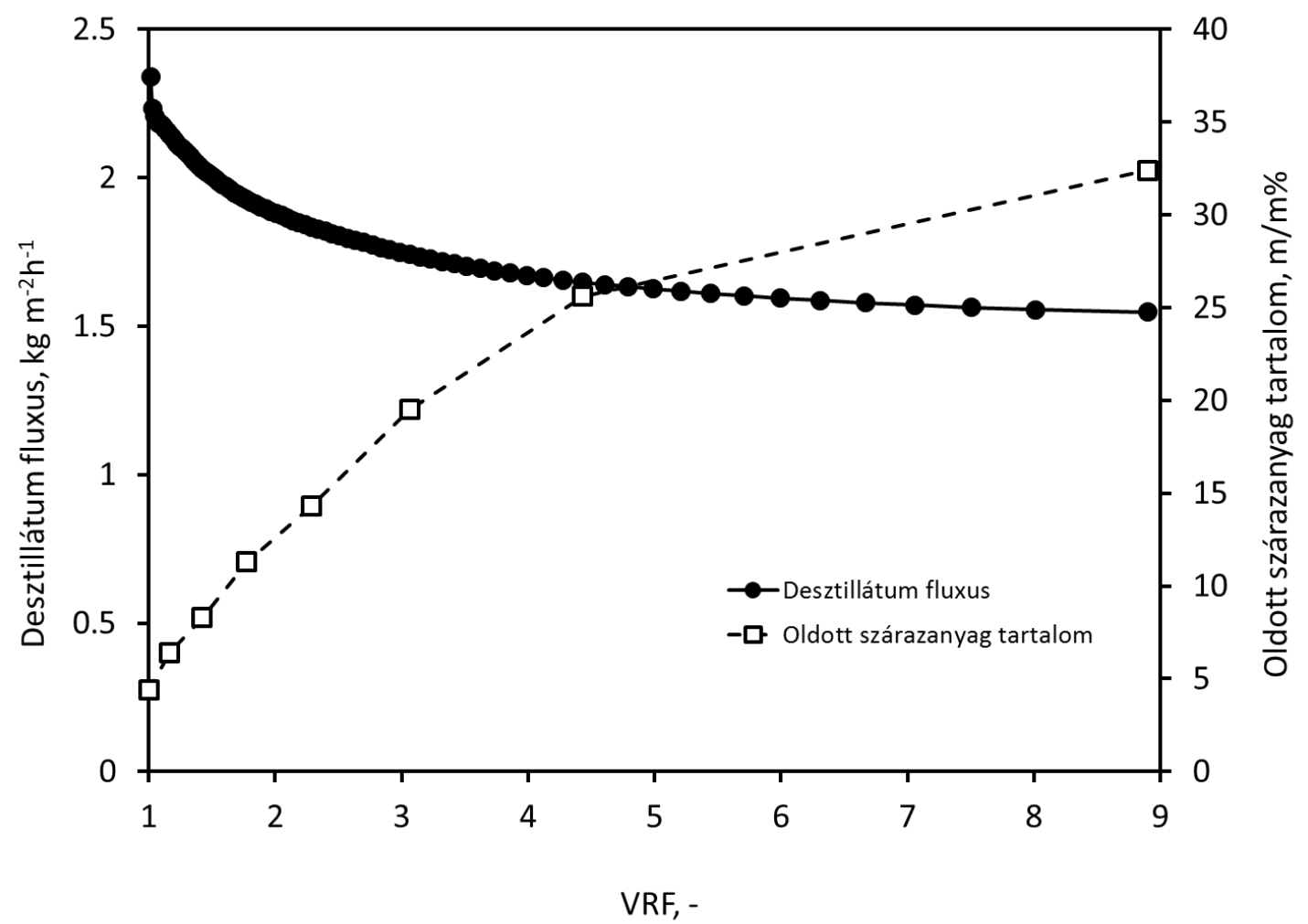

43. ábra Zsályakivonat végsürítése ozmotikus desztillációval $\left(\mathrm{T}=25^{\circ} \mathrm{C}, \mathrm{Q}_{\mathrm{rec}}=30 \mathrm{Lh}^{-1}\right)$

Ettől függetlenül az ozmotikus desztilláció a kiindulási 4,38 m/m\%-os szárazanyag tartalmat sikeren megemelte egészen 32,4 m/m\%-ra, ami az instatizálás szempontjából megfelelö összetétel. A 
kiindulási, 2,5 L mennyisége lecsökkent 0,28 L koncentrált zsályakivonat térfogatra, ami VRF=8,93 sürítési arányt jelent.

\subsubsection{Zsályakivonat bioaktív komponseinek vizsgálata}

A következő alfejezetben a zsályakivonat összes polifenol tartalmának, összes flavonoid tartalmának, antioxidáns kapacitásának, valamint jellemző polifenol vegyületeinek vizsgálata során elért eredményeimet ismertetem.

\subsubsection{Zsályakivonat összes polifenol, összes flavonoid és antioxidáns kapacitásának vizsgálata}

A 7. táblázat mutatja a spektrofotometriás analitikai mérések eredményeit. A mikroszürési mủveleti egység után nem történt elemzés, mivel a retentátum és a szürlet refraktometriásan mérhető oldott szárazanyag-tartalma megegyezett $(0,9 \mathrm{~m} / \mathrm{m} \%)$. Ez azt jelenti, hogy a membrán nem tartja vissza az oldott szárazanyagot, és mivel a fenolos vegyületek oldott állapotban vannak, valamint átlagos méretük jóval kisebb, mint az alkalmazott mikroszürő membrán pórusai $(0,45 \mu \mathrm{m})$, így a mikroszürés permeátumának vizsgálatát nem tartottam szükségesnek.

7. táblázat Zsályakivonat összes polifenol, flavonoid és antioxidáns aktivitás értékei

\begin{tabular}{|c|c|c|c|}
\hline & $\begin{array}{c}\text { TPC, mg GSE/mL } \\
\text { kivonat }\end{array}$ & $\begin{array}{c}\text { TFC, mg (+) } \\
\text { KE/mL kivonat }\end{array}$ & $\begin{array}{c}\text { AA (IC } \mathbf{5 0}), \\
\text { mL/mg DPPH }\end{array}$ \\
\hline Kiindulási zsályakvonat & $2,656 \pm 0,100$ & $2,491 \pm 0,039$ & $7,364 \pm 0,113$ \\
\hline Elősürített kivonat & $9,383 \pm 0,012$ & $7,746 \pm 0,024$ & $2,347 \pm 0,092$ \\
\hline Végsürítmény & $77,050 \pm 0,495$ & $64,744 \pm 3,349$ & $0,264 \pm 0,008$ \\
\hline
\end{tabular}

A 7. táblázat jól szemlélteti, hogy a folyamat előrehaladtával nőtt a minták összes polifenol és flavovnoid tartalma, valamint antioxidáns hatása (kevesebb oldat volt elegentő $1 \mathrm{mg}$ DPPH gyök 50\%-os gátlásához). Az összes polifenol és flavonoid a zsályanövény 80 percig tartó, $80^{\circ} \mathrm{C}$-on történő vizes extrakciója során Torun munkájában 3,444 mg GSE/ mL kivonat és 2,920 mg (+)KE/mL kivonat koncentrációként lett meghatározva (Torun et al., 2014). Az általam elöállított és megmért értékek 2,656 GSE/ mL kivonat és 2,491 mg $(+) \mathrm{KE} / \mathrm{mL}$ kivonat, amely kissé alacsonyabb érték. Ez a különbség eredhet a keverési eljárás intenzitásának különbségéből, a levelek felaprítási módjának, és 
ezzel az anyagátadási felület méretének különbségéből, valamint akár maga a növény származásából, mivel a két kiindulási minta eltérő évben és eltérö területről volt begyüjtve.

Ahhoz, hogy kijelenthessem, valójában történt-e veszteség, illetve milyen hatékony volt a koncentrálási folyamat, ezeket az értékeket a sürítési arány értékeivel korrigálni kell, ezt mutatja a 44. ábra.

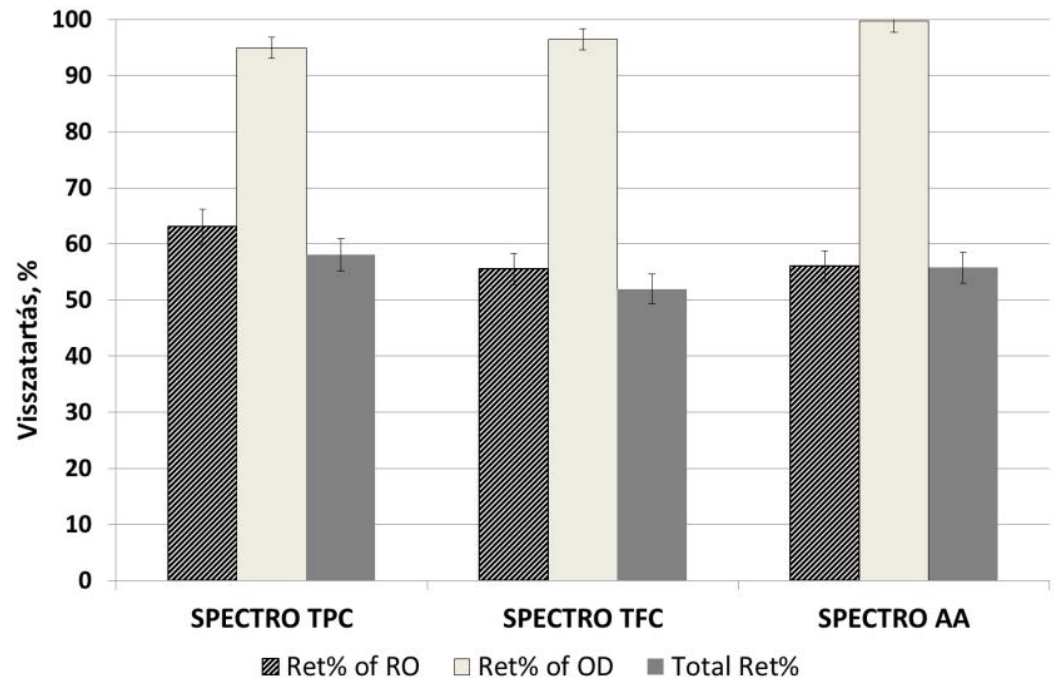

44. ábra A zsályakivonat sürítési müveleti egységeinek, és az egész folyamarta vonatkozatott visszatartások értékei

A 44. ábrán jól megfigyelhető, hogy az elősürítési, fordított ozmózisos folyamat során mind a három analitikai paraméter esetében a visszatartások értékei mérsékeltnek tekinthetőek. A polifenolokat a fordított ozmózis müvelete $63 \%$, a flavonoidokat $56 \%$, és az antioxidáns kapacitást is mindössze 53\%-ban tudta visszatartani. Az ozmotikus desztillációs mérések eredményei meggyőzőek: itt minden esetben legalább 95\%-os visszatartást sikerült elérni (95\%, 96\% és 99\% a TPC, TFC és összes visszatartás tekintetében). Kijelenthető így, hogy az egész folyamat minőségi paramétereit a fordított ozmózisos müveleti egység határozza meg - bár ezzel a folyamat időbeli hatékonysága növelhető, viszont ez a fajta előny a jelentős mértékben csökkenő termékminőségben eltünik.

Mivel a szakirodalomban gyógynövény koncentrátumok elkészítésére kapcsolt membrános eljárásokkal nincs példa, ezért eredményeimet gyümölcslé sürítésének során kapott eredményekkel hasonlítom össze. AGUIAR és mtsai (2012) almalevet koncentráltak fordított ozmózis és ozmotikus desztilláció segítségével és vizsgálták az összes polifenol tartalom és antioxidáns kapacitás változását. Munkájukban sikeresen tudtak 89\%-os visszatartást elérni fordított ozmózissal a polifenol tartalomra, viszont az antioxidáns kapacitást tekintve 79\%-os visszatartást értek csak el, és 92\%-os visszatartást 
ozmotikus desztillációval polifenol tartalomra és 78\%-os visszatartást antioxidáns kapacitásra. A náluk is jelentősnek mondható értékes anyag csökkenést az antioxidáns tekintetében az oxidatív stresszenek tulajdonították, amit a gyümölcslé a kezelés során elszenvedett.

\subsubsection{Zsályakivonat polifenelos vegyületeinek megatározása}

Nyolc különböző polifenolt mutatott ki a vizsgálat: négy fenolsavat (kávésav, p-kumársav, ferulasav, rozmaringsav) és további négy flavonoidot (rutin, luteolin, heszperetin, apigenin). A 45. ábra mutatja minták folyadékkromatográfiás kromatorgamját.

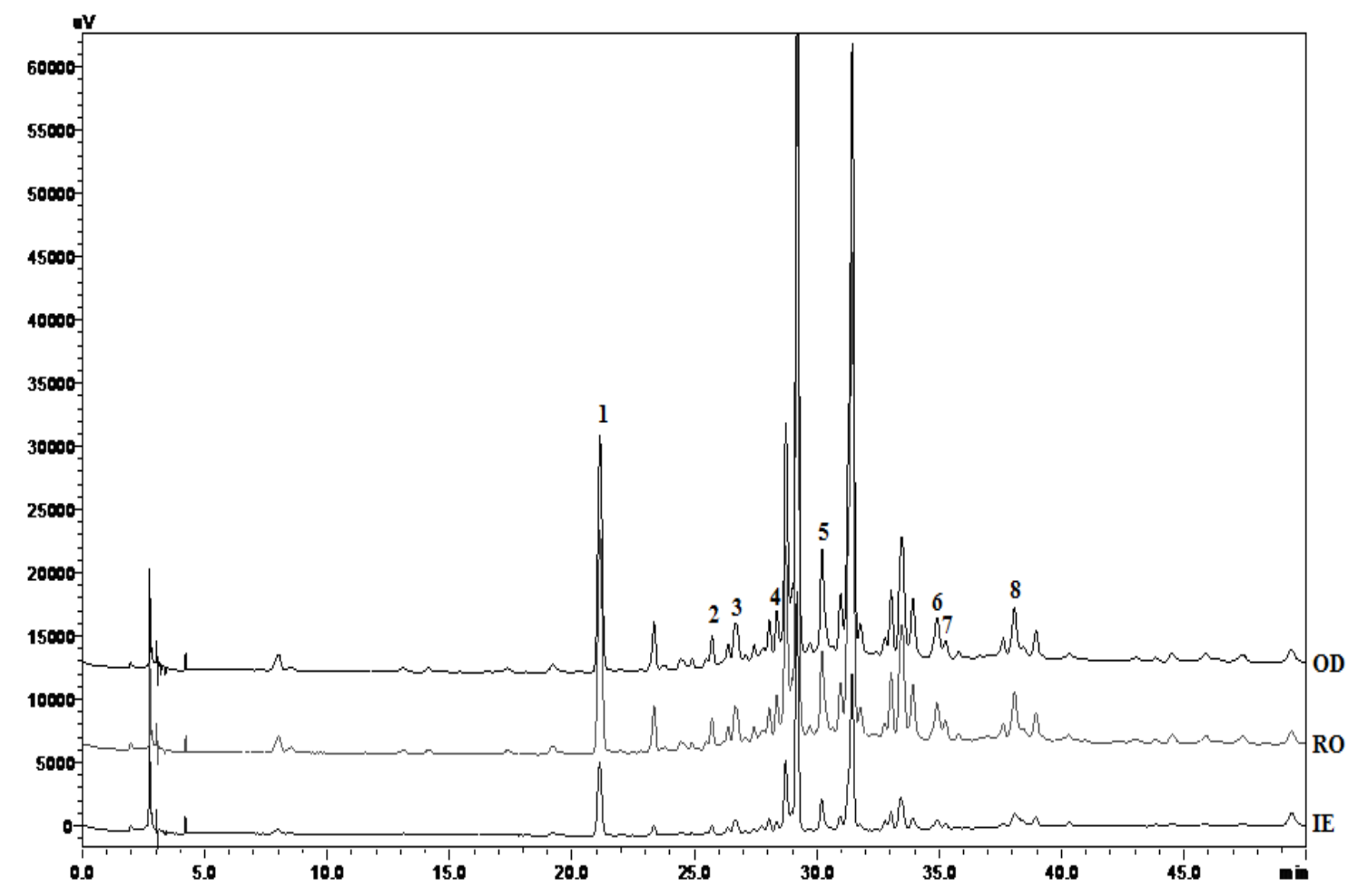

45. ábra HPLC kromatogramok a kiindulási (Initial extract (IE)), elősürített (RO) és végsürített (OD) zsályakivonat polifenol komponenseiről (1. kávésav, 2. p-kumársav, 3. feralsav, 4. rutin, 5. rosmaringsav, 6. luteolin, 7. heszperetin, 8. apigenin)

A 8. táblázat mutatja az egyedi komponensek koncentrációit a kiindulási kivonatban, az elősűrített, fordított ozmózissal nyert sürítményben, és az ozmotikus desztillációval előállított végsürítményben. A táblázatból egyértelmüen kiolvasható az individuális komponensek koncentrációjának növekvő tendenciája. 
8. táblázat Az egyedi polifenolok koncentrációja a részfolyamatokból vett mintákban

\begin{tabular}{|c|c|c|c|c|c|}
\hline & Retenciós & Molekulat & Kiindulási & Elösürített & Végsürítmény, \\
& idő, min & ömeg, & kivonat, & kivonat, $\mathbf{~ m g m L ~}^{-1}$ & mgmL $^{-1}$ \\
gmol $^{-1}$ & mgmL $^{-1}$ & & \\
\hline kávésav & 21,1 & 180,16 & $0,305 \pm 0,048$ & $1,294 \pm 0,086$ & $10,482 \pm 0,006$ \\
\hline p-kumársav & 26,5 & 164,16 & $0,330 \pm 0,027$ & $1,705 \pm 0,067$ & $13,238 \pm 0,019$ \\
\hline ferulasav & 27,0 & 194,18 & $0,270 \pm 0,005$ & $0,592 \pm 0,007$ & $4,901 \pm 0,003$ \\
\hline rutin & 28,5 & 610,52 & $0,260 \pm 0,001$ & $1,285 \pm 0,013$ & $10,720 \pm 0,006$ \\
\hline rozmaringsav & 30,2 & 360,31 & $0,340 \pm 0,002$ & $1,526 \pm 0,008$ & $13,160 \pm 0,007$ \\
\hline luteolin & 35,0 & 286,24 & $0,578 \pm 0,002$ & $0,992 \pm 0,011$ & $8,054 \pm 0,007$ \\
\hline heszperetin & 35,1 & 610,56 & $0,323 \pm 0,04$ & $0,685 \pm 0,062$ & $4,862 \pm 0,027$ \\
\hline apigenin & 38,0 & 270,24 & $0,257 \pm 0,003$ & $0,453 \pm 0,015$ & $3,731 \pm 0,020$ \\
\hline
\end{tabular}

Az 46. ábra szemlélteti, hogy az egyedi komponenseket a fordított ozmózisos membrán, az ozmotikus desztillációs eljárás mennyire tudta visszatartani. Az egész sürítési folymatra vonatkozó visszatartásokat szintén feltüntettem táblázatban, melyek az egész folyamat, a polifenolok megőrzésének hatékonyságára vonatkozó információkat hordozza.

A táblázatból láthatjuk, hogy a fordított ozmózis folyamata egyes komponenseket viszonylag nagy hatékonysággal tudott visszatartani, viszont egyes polifenolos alkotók visszatartása nagyon alacsonynak mondható. A rutin, p-kumársav és rozmaringsav vegyületek visszatartása 80-90\%-os, ezzel szemben a ferulasav, heszperetin luteolin és apigenin visszatartásai nagyon alacsonynak mutatkoztak (30-40\%). Ez a fajta tendencia nem magyarázható a molekulák méretével, mivel a rutin nagy molekulatömegével $\left(610,52 \mathrm{gmol}^{-1}\right)$ magas visszatartással rendelkezett $(88 \%)$, ezzel szemben a legnagyobb molekulatömegü heszperetin mindössze 34-35 \% mutatott. A jelenségek okainak több magyarázata is lehet. A molekulaméret alapján történő szétválasztás mellett a fordított ozmózis anyagátadása során a membránba való beoldódást is figyelembe kell vennünk. Így fontos a különböző molekulák hidrofób/hidrofil jellegét, térbeli elrendeződését is figyelembe venni a membránnal való 
viselkedés szempontjából. Ezek vizsgálatát érdemes lenne elsőként standard oldatokkal megvalósítani, majd különböző összetételek mellett, hogy valós képet kapjunk a jelenség valódi természetéről, mely nem volt tárgya jelenlegi munkámnak.

ONSEKIZOGLU és mtsai (2013) gránátalmalé kémiai összetevőit határozták meg és nyomon követték a lé karatkerének változását a koncentrálási folyamat során. A mért komponensek közül az ozmotikus desztilláció során a galluszsav, az ellágsav a (+) katechin, a klorogénsav, valamint a kávésav komponensek visszatartásai 56,4 és 86,2 \% között volt kimutatható.

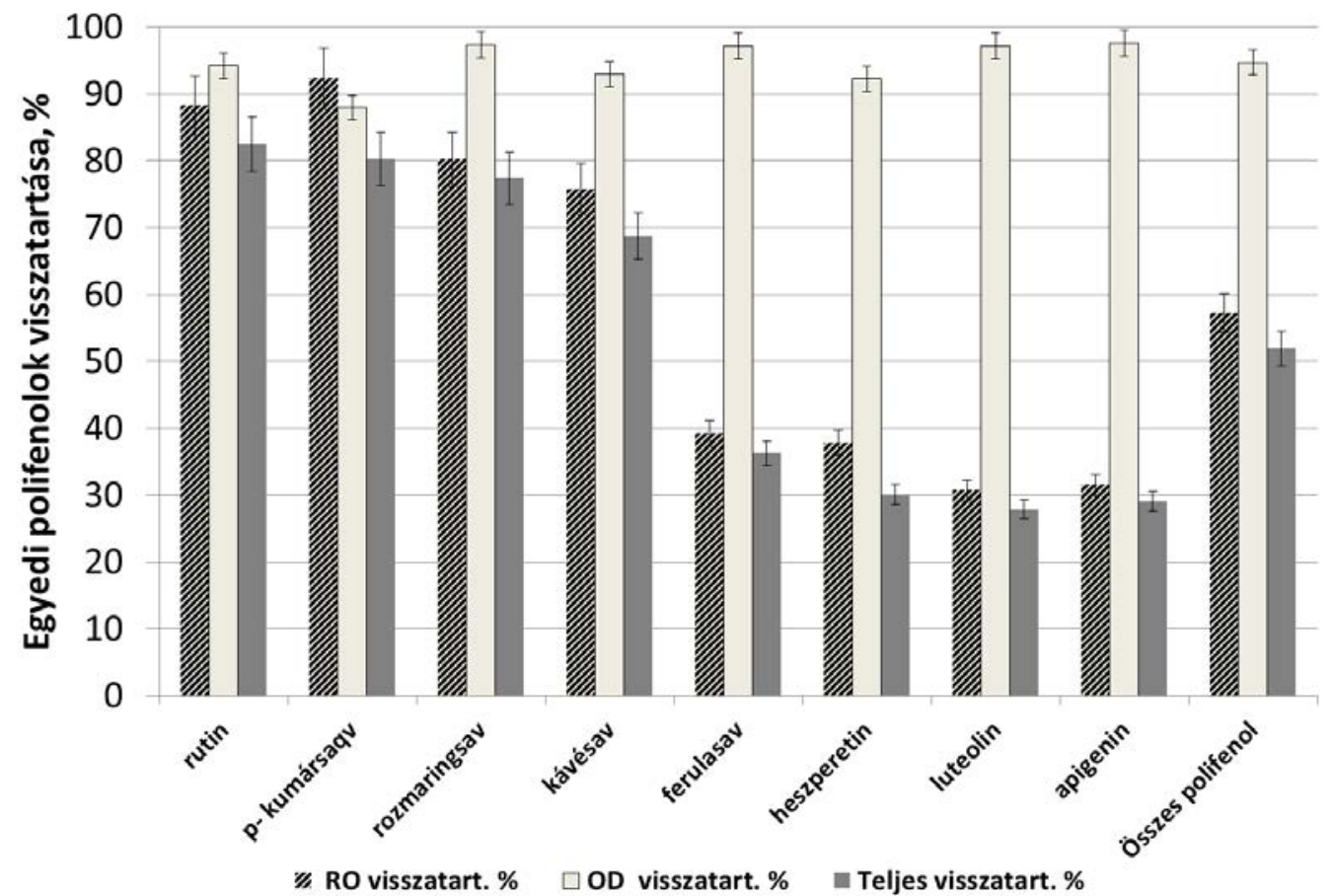

46. ábra Az egyedi polifenolok visszatartása a különböző koncentrálási müveletek során

Az ozmotikus desztilláció visszatartások magas, minden esetben legalább 92\%-os visszatartást eredményeztek. Ez alátámasztja az elvi alapokat, miszerint a polifenolok alapvetően nem jellemzően illékony komponensek, így nem képesek átpárologni az ozmotikus ágens oldalába. CASSANO (2003) munkájában fény derült arra, hogy a fordított ozmózis során citrus gyümölcsök összes antioxidáns kapacitás értékében csökkenés mutattak ki, amit a nagy alkalmazott transzmembrán nyomáskülönbség hatásának (50 bar) tulajdonítottak. 


\section{4. Új ozmotikus oldatok lehetőségének vizsgálata}

\subsubsection{Különböző ozmotikus oldatok hatékonyságának összehasonlítása}

Az irodalmi részben megfogalmazott szempontok alapján kiválasztott ozmotikus oldatokat desztillált vizes betáplálás mellett vizsgáltam meg, így elkerülve a betáplálás oldalon kialakuló határréteg koncentráció polarizációs hatását. A 47. ábra mutatja az eredményeket, szakaszos müveletként vizsgálva a folyamatot, ennek okán jelentkezik a fluxus csökkenése, ami a csökkenő hajtóerőből eredeztethető. Minden egyes mérés esetében $1000 \mathrm{~g}$ telített kiindulási ozmotikus oldattal kezdődött a folyamat, és 25 percig zajlott a müvelet. Az üzemeltetési körülmények minden esetben megegyeztek $\left(\mathrm{T}=30^{\circ} \mathrm{C}, Q_{\text {betáp }}=22 \mathrm{~L} / \mathrm{h}\right)$. Az ozmotikus oldat a kapillárisokban áramlott, mivel az előkísérletekhez szükséges sóalapanyag mennyiséget így minimalizáltam. Minden esetben korrigáltam a membrán aktív felületét azzal, hogy a desztillátum iránya köpenytérből haladt befelelé a kapillárisokba.

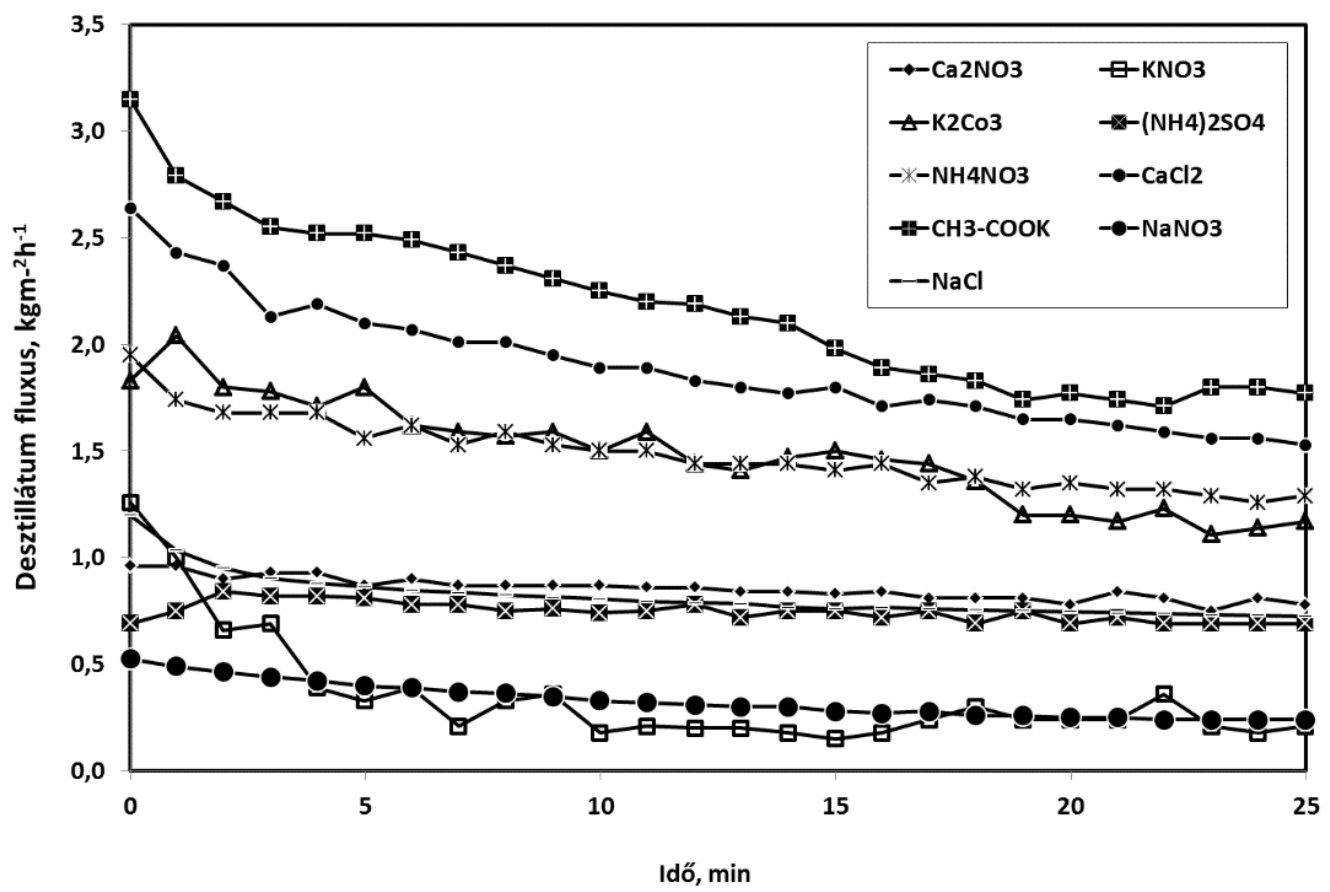

47. Különböző ozmotikus oldatok desztillátum fluxusa (MD $020 \mathrm{CP} 2 \mathrm{~N})\left(\mathrm{T}=30^{\circ} \mathrm{C}\right.$, Qbetáp $\left.=22 \mathrm{Lh}^{-1}\right)$

Jól látható az ábrán, hogy a legnagyobb hatékonyságot a $\mathrm{CH}_{3} \mathrm{COOK}$ oldat mutatta, majd a leggyakrabban alkalmazott $\mathrm{CaCl}_{2}$ követi, utána $\mathrm{K}_{2} \mathrm{CO}_{3}$ és $\mathrm{NH}_{4} \mathrm{NO}_{3}$, ezután a $\mathrm{Ca}\left(\mathrm{NO}_{3}\right)_{2}, \mathrm{NaCl}$ és $\left(\mathrm{NH}_{4}\right)_{2} \mathrm{SO}_{4}$, végül pedig a $\mathrm{NaNO}_{3}$ és $\mathrm{KNO}_{3}$. 
Nyilvánvaló, hogy szakaszos rendszerek során a leggyorsabb folyamat eredményezi a legnagyobb hatjóerö, azaz fluxuscsökkenést az intenzívebb hígulás miatt. Ezért, hogy össze lehessen hasonlítani a különböző oldatok „maximális hatjóerejét”, azaz a folyamat telített állapotbeli értékeit, a 9. táblázat mutatja a különböző oldatok maximálisan kinyerhető desztillátum fluxus kapacitását. Ezeket úgy állapítottam meg, hogy azoknak a fluxusértékeknek átlagát hasonlítottam össze, ahol az ozmotikus ágensek hígulása nem érte el az $1 \%$-ot (mivel ennyit hígult a leglassabb, $\mathrm{KNO}_{3}$ oldat, tehát ezt kellett alapnak vennem).

9. táblázat Ozmotikus oldatok integrált desztillátum fluxusa, 1\%-os hígulás mellett $\left(30^{\circ} \mathrm{C}\right)$

\begin{tabular}{|c|c|c|}
\hline Szervetlen sók & $\begin{array}{l}\text { Integrált desztillátum } \\
\text { fluxus, } \mathrm{kgm}^{-2} \mathrm{~h}^{-1}\end{array}$ & Fluxusnövekmény, \% \\
\hline $\mathrm{CH}_{3} \mathrm{COOK}$ & 2,97 & $+17 \%$ \\
\hline $\mathrm{CaCl}_{2}$ & 2,54 & - \\
\hline $\mathrm{K}_{2} \mathrm{CO}_{3}$ & 1,83 & $-28 \%$ \\
\hline $\mathrm{NH}_{4} \mathrm{NO}_{3}$ & 1,79 & $-30 \%$ \\
\hline $\mathrm{Ca}\left(\mathrm{NO}_{3}\right)_{2}$ & 0,94 & $-62 \%$ \\
\hline $\mathrm{NaCl}$ & 0,82 & $-68 \%$ \\
\hline$\left(\mathrm{NH}_{4}\right)_{2} \mathrm{SO}_{4}$ & 0,77 & $-70 \%$ \\
\hline $\mathrm{NaNO}_{3}$ & 0,51 & $-80 \%$ \\
\hline $\mathrm{KNO}_{3}$ & 0,35 & $-86 \%$ \\
\hline
\end{tabular}

A 9. táblázat alapjána $\mathrm{CH}_{3} \mathrm{COOK}$ oldat 17\%-kal nagyobb desztillátum fluxust képes biztosítani, szemben a leggyakrabban alkalmazott referencia $\mathrm{CaCl}_{2}$-dal. Az összes többi vizsgált anyag hatékonysága kisebbnek bizonyult a referencia oldattól. Így, az előkísérletek alapján, a $\mathrm{CH}_{3} \mathrm{COOK}$-ot választottam további vizsgálataim alapjául.

\subsubsection{Kísérletterv kiértékelése a kiválasztott ozmotikus oldat múveleti paramétereire}

A müveleti paraméterek desztillátum fluxusra gyakorolt hatását STATISTICA program segítségével értékeltem ki, és teljes faktoros analízissel, hogy alátámasszam a kísérletek grafikus kiértékelése során kapott eredményeket. Felállítottam egy olyan célfüggvényt, amely a főhatások, azaz az egyes müveleti paraméterek mellett azok interakcióját, együttes hatásait is tartalmazza. 
A statisztikai analízis elvégzéséhez az 48. ábrán bemutatott fluxus görbékről minden egyes kísérlet esetén integrált átlagfluxus értékeket számoltam. A kapott átlag értékek jól közelítik a különböző paraméterek mellett végzett méréseket. Az integrált átlag értékeket az M.IV. melléklet tartalmazza.

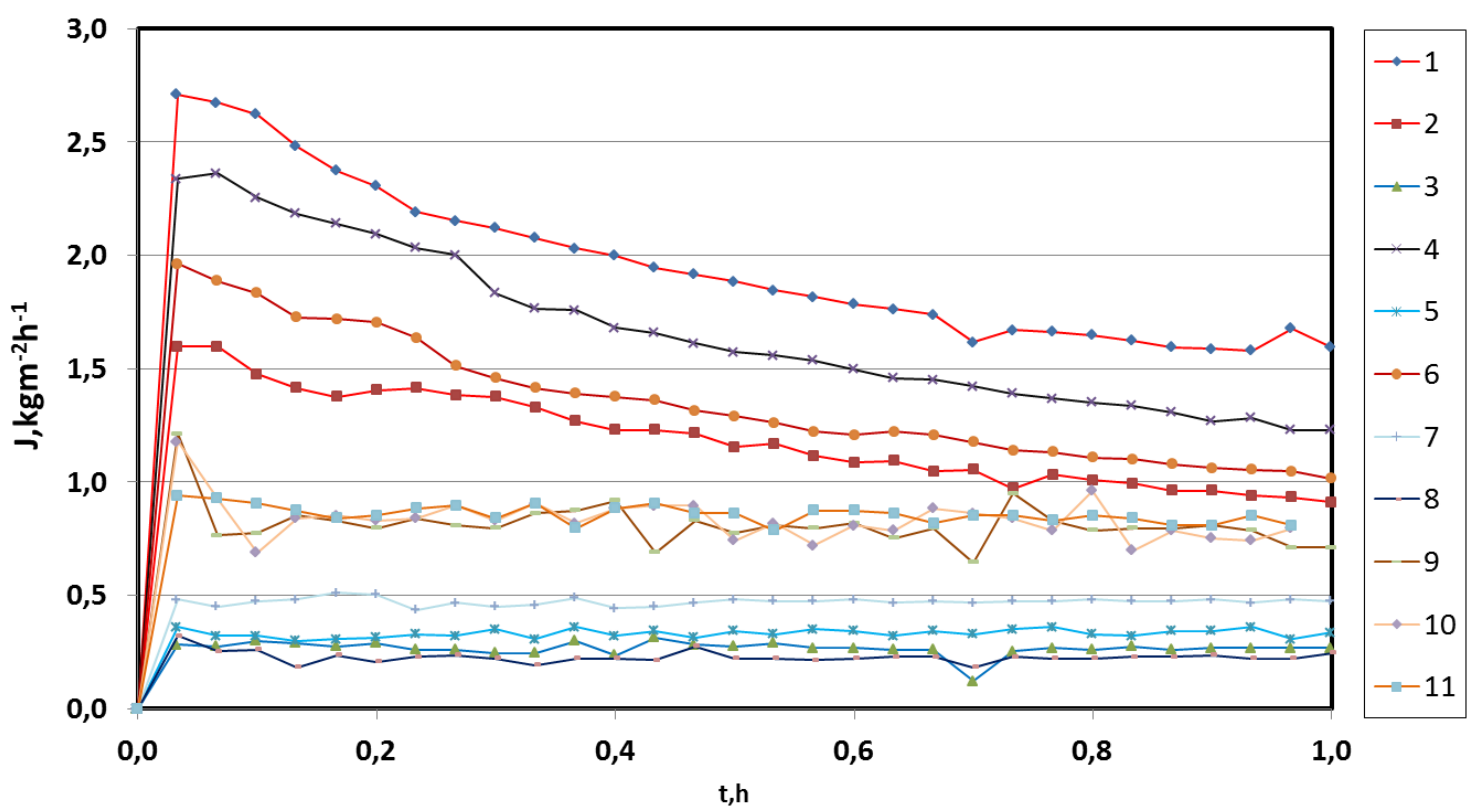

48. ábra A fluxusértékek a kísérletterv alapján

A 49. ábra grafikusan szemlélteti a kísérletterv sarokpontjaiban elvégzett mérések integrál fluxus értékeit, a számok az oszlopok felett a mérések sorszámét jelöli. Ebből az ábrából már lehet feltételezni, hogy a koncentrációnak jelentős hatása van a vizsgált tartományon belül is, és a betáplálás hőmérsékletének hatása is feltételezhető. De ahhoz, hogy egyértelmű kijelentéseket tehessünk, meg kell néznünk, hogy a faktoranalízis milyen értékeket ad meg. 


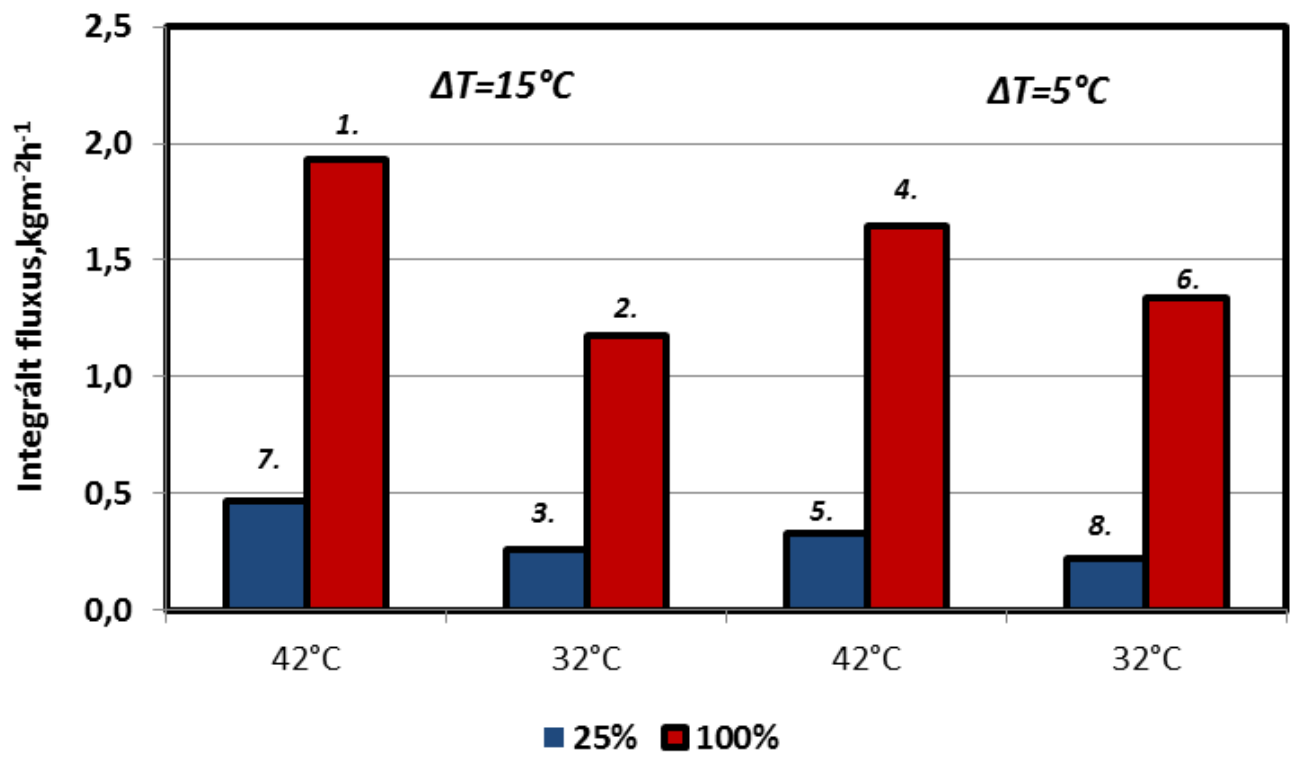

49. Az integrált értékek oszlopdiagramos összehasonlítása

Az elvégzett statisztikai elemézt 95\%-os szignifikancia szinten végeztem el. A 10. táblázat és M.V-VI. mellékletek bemutatják az elemzés statiszikai eredményét. Egyértelmüen látszik az illesztett lienáris egyenlet $\mathrm{R}^{2}=0,99233$ értéke, mely bizonyítja a modell kellő pontosságát. A piros szín mutatja a sziginfikáns hatásokat is, melyet az 50 és 51 . ábra is személtet.

10. táblázat $2^{\mathrm{p}}$-ksérletterv kiértékelése, 95\%-os szignifikancia szinten

\begin{tabular}{|c|c|c|c|c|c|c|c|c|c|c|}
\hline \multirow[b]{2}{*}{ Factor } & \multicolumn{10}{|c|}{$\begin{array}{l}\text { Effect Estimates; Var.:DV_ 1; R-sqr=,99233; Adj: } 97443 \text { (Design: } 2^{\star \star}(3-0) \text { design (Spreadsheet11) in nagyonjó.stw) } \\
2^{\star \star}(3-0) \text { design; MS Residual=,0084159 } \\
\text { DV: DV_1 }\end{array}$} \\
\hline & Effect & Std.Err. & $t(3)$ & $p$ & $\begin{array}{c}-95, \% \\
\text { Cnf.Limt }\end{array}$ & \begin{tabular}{|r|}
$+95, \%$ \\
Cnf.Limt
\end{tabular} & Coeff. & $\begin{array}{l}\text { Std.Err. } \\
\text { Coeff. }\end{array}$ & $\begin{array}{c}-95, \% \\
\text { Cnf.Limt }\end{array}$ & $\begin{array}{r}+95, \% \\
\text { Cnf.Limt }\end{array}$ \\
\hline Mean/Interc. & 0.890818 & 0,027660 & 32,20581 & 0,000066 & 0,802791 & 0,978846 & 0,890818 & 0,027660 & 0,802791 & 0,978846 \\
\hline (1)Sat(\%) & 1,203725 & 0,064869 & 18,55628 & 0,000342 & 0,997283 & 1,410167 & 0,601863 & 0,032434 & 0,498642 & 0,705083 \\
\hline (2) $\mathrm{T}\left({ }^{\circ} \mathrm{C}\right)$ & 0,340775 & 0,064869 & 5,25329 & 0,013435 & 0,134333 & 0,547217 & 0,170387 & 0,032434 & 0,067167 & 608 \\
\hline (3)deltaT $\left({ }^{\circ} \mathrm{C}\right)$ & 0,073475 & 0,064869 & 1,13267 & 0,339695 & $-0,132967$ & 0,279917 & 0,036737 & 0,032434 & $-0,066483$ & 0,139958 \\
\hline 1 by 2 & 0,190175 & 0,064869 & 2,93168 & 0,060918 & $-0,016267$ & 0,396617 & 0,095087 & 0,032434 & $-0,008133$ & 0,198308 \\
\hline 1 by 3 & $-0,011825$ & 0,064869 & $-0,18229$ & 0,866977 & $-0,218267$ & 0,194617 & $-0,005913$ & 0,032434 & $-0,109133$ & 0,097308 \\
\hline 2 by 3 & 0,135325 & 0,064869 & 2,08613 & 0,128249 & $-0,071117$ & 0,341767 & 0,067662 & 0,032434 & $-0,035558$ & 0,170883 \\
\hline $1 * 2 * 3$ & 0,087325 & 0,064869 & 1,34618 & 0,270929 & $-0,119117$ & 0,293767 & 0,043663 & 0,032434 & $-0,059558$ & 0,146883 \\
\hline
\end{tabular}

A legerősebb szignifikáns hatása egyértelmüen az ozmotikus oldat koncentrációjának volt. További sziginfikáns hatása volt a betáplálás hőmérsékletének, így ebben az esetben is érdemes a lehető legmagasabb értéken múködtetni a folyamatot a nagyobb hatékonység elérése céljából. A hatásokat az 51. diagramon is szemléltetem. 


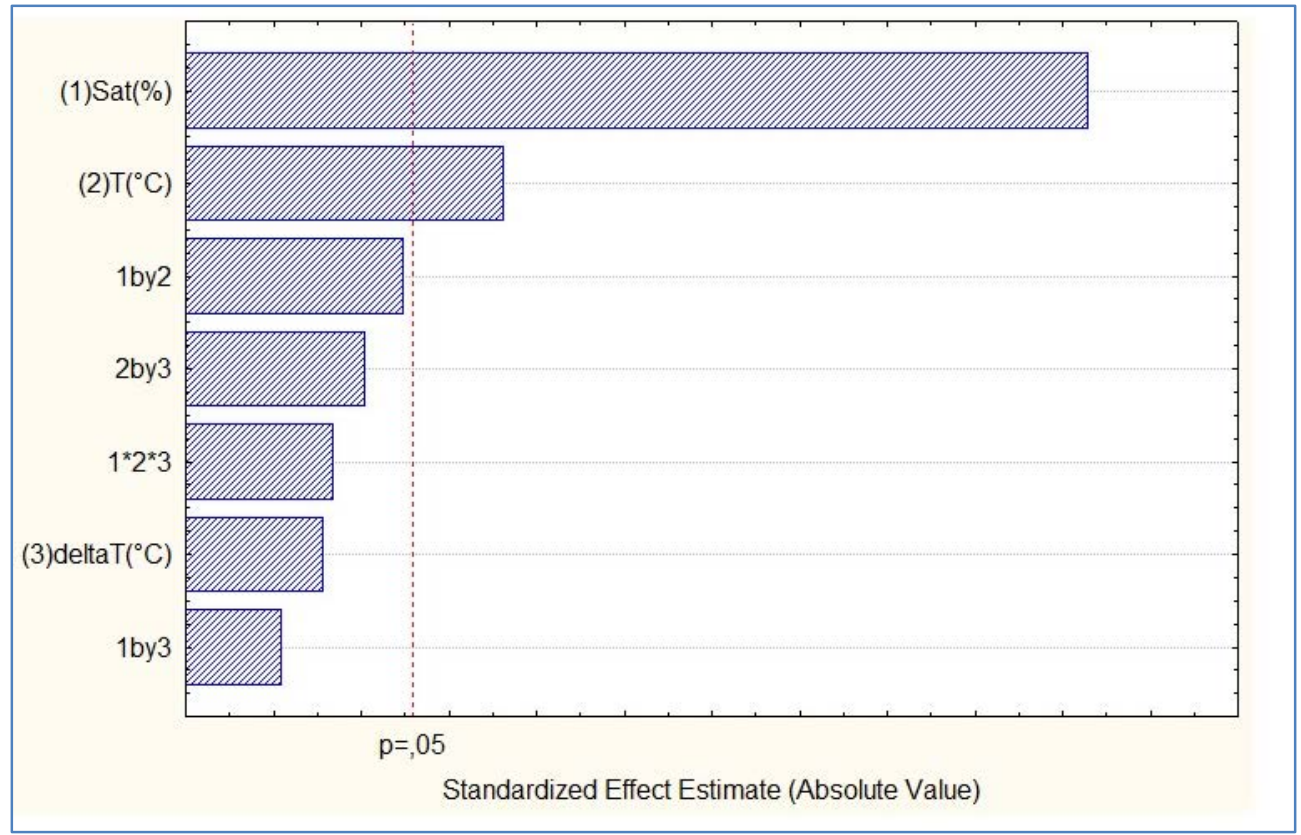

50. $2^{\mathrm{p}}$-kísérletterv fö- és kereszthatásokkal együtt ábrázolva

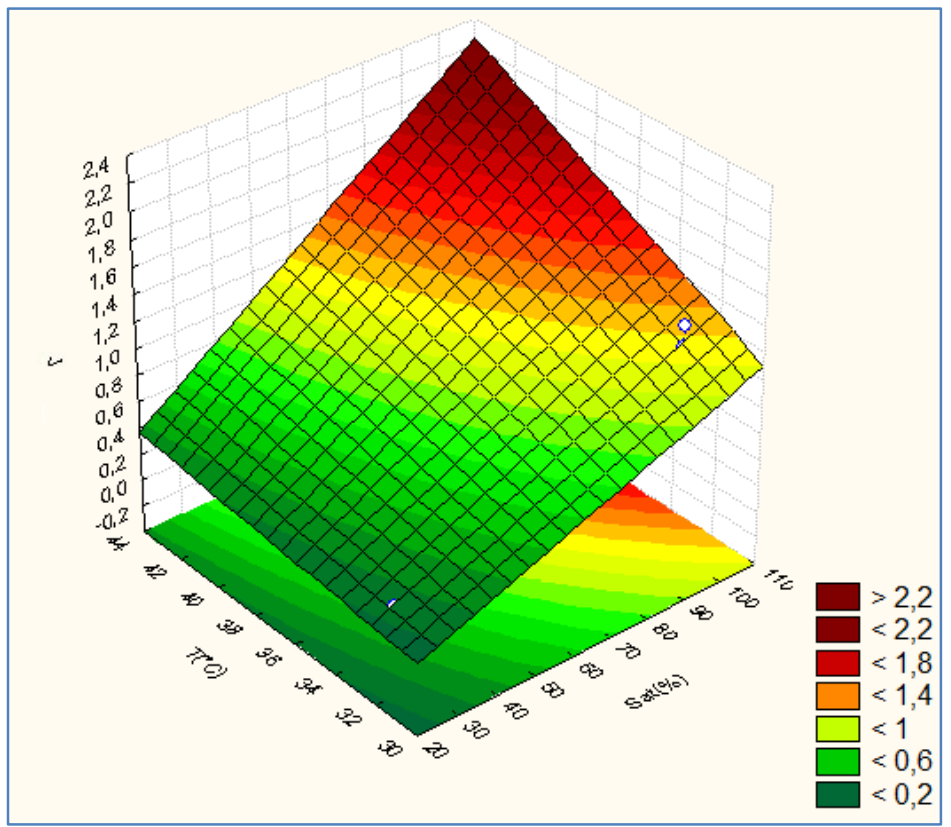

51. Szignifikáns hatások a desztillátum fluxusra, betáplálás hőmérséklete és az ozmotikus oldat koncentráció függvényében

A kiértékelés alapján továbbá az is egyértelmüen látszik, hogy a vizsgált tartományon belül $\left(\mathrm{T}_{\text {betáp }}=32-42 ; \Delta \mathrm{T}=5-15^{\circ} \mathrm{C}\right)$ a hőmérsékletkülönbség hatása nem tekinthető szignifikánsnak, $\mathrm{CH}_{3} \mathrm{COOK}$ ozmotikus oldat esetében. Így elkerülhető a művelet költségét növelő, ozmotikus ágens oldali hütés szükségessége. 
A $2^{\mathrm{p}}$ teljes faktoranalízis alapján, a szignifikáns hatásokat figyelembe véve a lineáris regresszió eredménye (9):

$$
J=0,8908+0,6019 \frac{C(\%)-62,5}{37,5}+0,1704 \frac{T\left({ }^{\circ} \mathrm{C}\right)-37}{5}
$$

melynek érvényessége $\mathrm{T}_{\text {betáp }}=32-42^{\circ} \mathrm{C}, \Delta \mathrm{T}=5-15^{\circ} \mathrm{C}$, ozmotikus oldat telítettsége $25-100 \%$ tartományban.

\subsection{Meggysürítmény kíméletes sürítése kapcsolt membrános eljárással}

A következő alfejezet a meggysürítmény kíméletes előállítását mutatja be kapcsolt membrántechnológiával. Mikroszüréssel történt a kiindulási meggylé elöszürése és tükrösítése, fordított ozmózisos eljárással történt az elősürítés, ezt követően különböző ozmotikus oldatokkal, ozmotikus desztillációval végeztem el a végsürítést. Vizsgáltam a mikroszürés csírátlanító hatását, a fordított ozmózis és az ozmotikus desztilláció hatását a meggylé összes polifenol tartalamára és antioxidáns kapacitására vontakozóan.

\subsubsection{Meggylé előszürése és hideg csírátlanítása mikroszüréssel}

A kipréselt és vásznon előszürt meggylevet 0,45 $\mu \mathrm{m}$ pórusú mikroszürő membránon szürtem a tükrösítés és a mikroorganizmusok eltávolítása céljából. A 52. ábra mutatja a permeátum-fluxus változását a mikroszürés időbeli előrehaladásának függvényében. Jól követhető, hogy az előszürt meggylé permeátum fluxusa $29 \mathrm{Lm}^{-2} \mathrm{~h}^{-1}$-ról 9,8 $\mathrm{Lm}^{-2} \mathrm{~h}^{-1}$-ra csökken, az eltömődés miatt. A permeátum és a retentátum szárazanyag tartalma megegyezett, 5,8 Brix, mely azt igazolja, hogy az oldott szénhidráttartalmat a membrán nem tartotta vissza, mindössze a szuszpendált, illetve kolloidálisan jelenlévő anyagokat, melyek okozták a szürési eltömődést. 


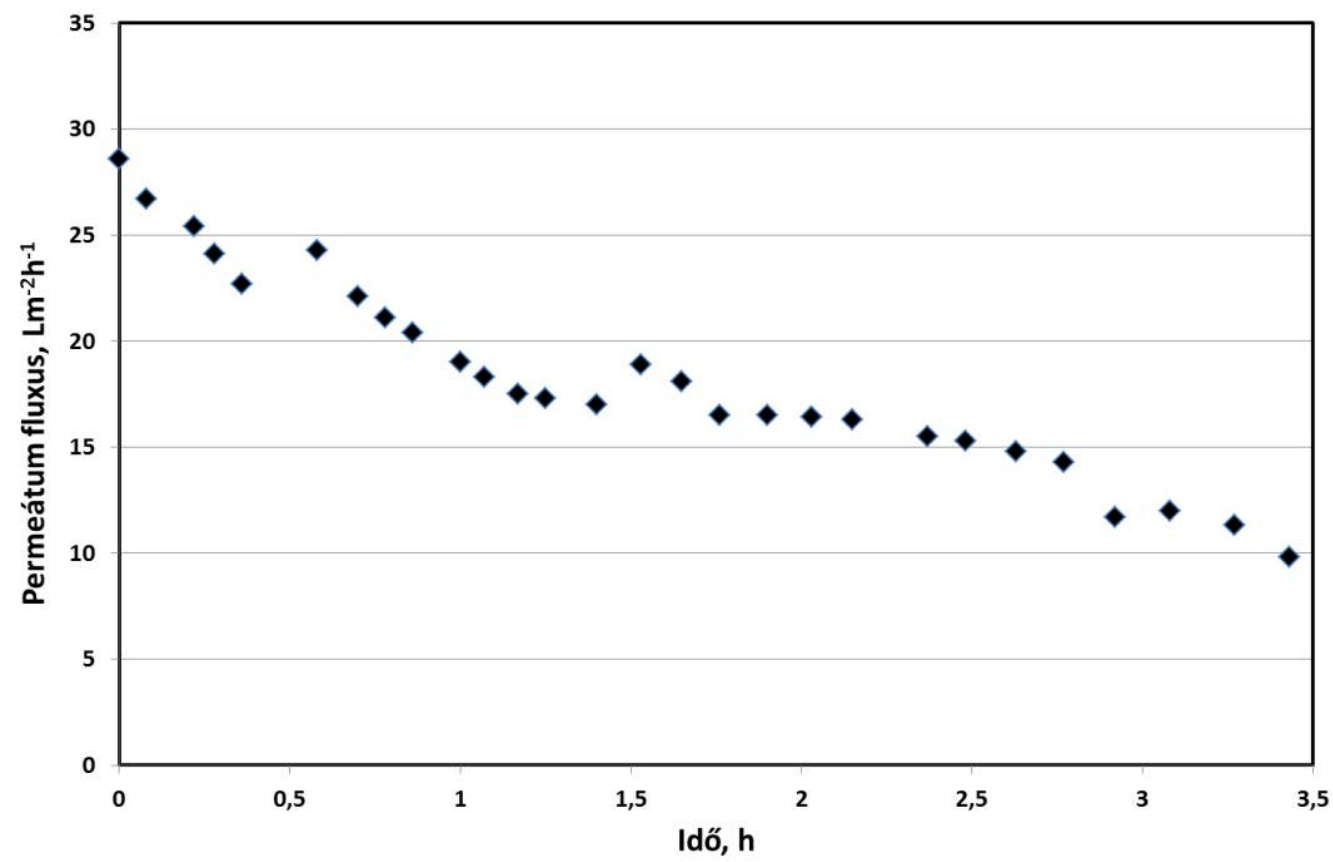

52. Az előszürt meggylé permeátum fluxusának időbeli lefolyása, $20^{\circ} \mathrm{C}$-on, 1,5 bar transzembrán nyomáskülönbség és $Q_{\text {rec }}=500 \mathrm{Lh}^{-1}$ üzemeltetési térfogatáram mellett

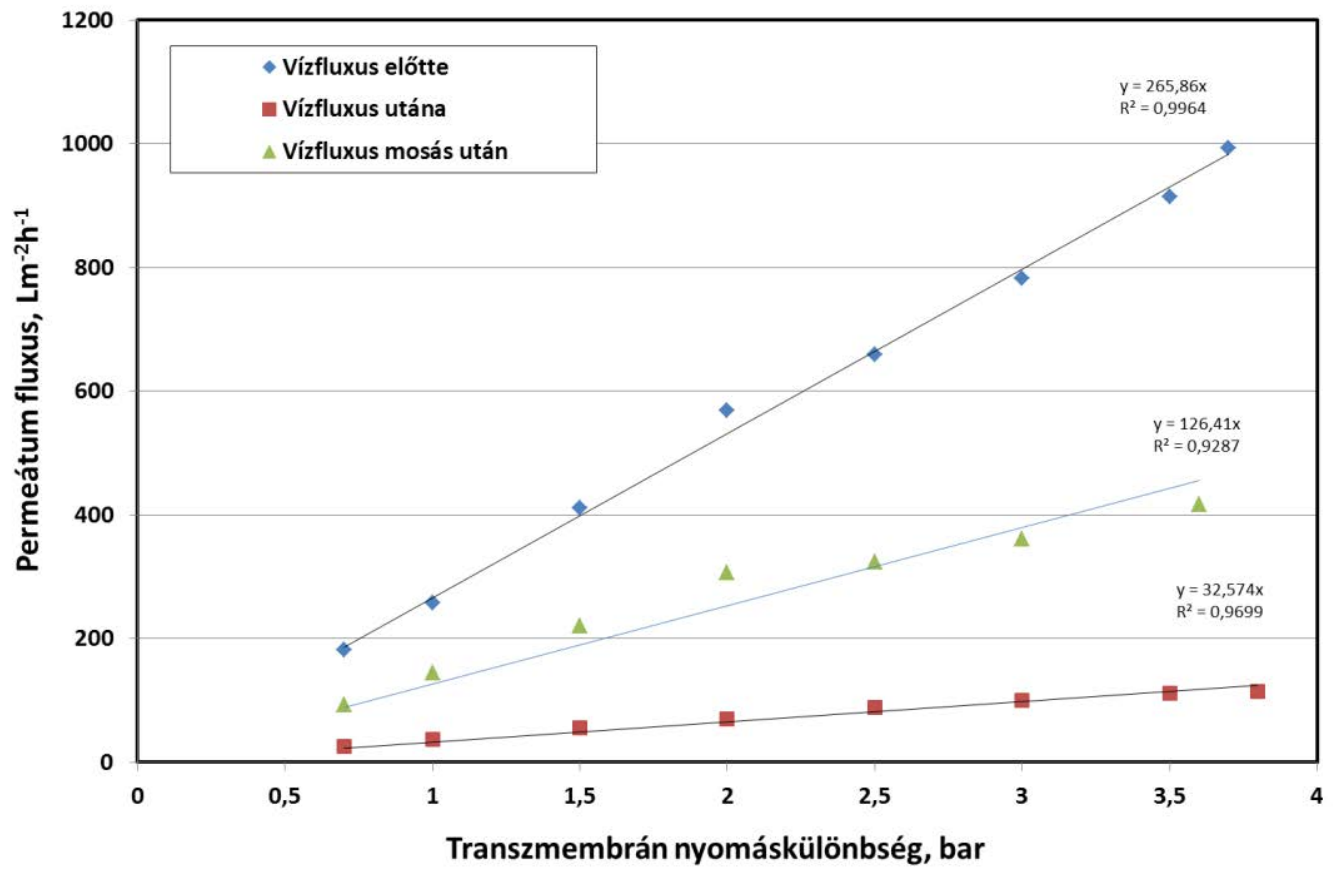

53. Ioncserélt vizes mérések a permeabilitási tényező meghatározásáhoza művelet előtt, után és a mosási procedúra elvégézése után $20^{\circ} \mathrm{C}$-on, 1,5 bar transzembrán nyomáskülönbség és $\mathrm{Q}_{\mathrm{rec}}=500 \mathrm{Lh}^{-1}$ üzemeltetési térfogatáram mellett. 
A 53. ábráról leolvasható, hogy a mikroszürő membrán kiindulási, ioncserélt vízre vonatkozatott permeabilitási együtthatója 256,86 $\mathrm{Lm}^{-2} \mathrm{~h}^{-1} \mathrm{bar}^{-1}$, mely a megggylé sürítése során folyamatosan csökkent, és a folyamat végére egy enyhe ioncserélt vizes öblítés után közel a tizedére csökkent, az értéke 32,57 $\mathrm{Lm}^{-2} \mathrm{~h}^{-1}$ bar $^{-1}$. Ez a csökkenés jelenti a membrán pórusainak az eltömödését, és a membrán felületéről egyszerü fizikai módszerrel nem eltávolítható fluxust csökkentő lerakódásokat.

Végül alapos Na-hipokloritos mosás után csak részben tudtam az eredei permeabiltiást visszanyerni, így a permeabilitási tényező értéke $126,41 \mathrm{Lm}^{-2} \mathrm{~h}^{-1} \mathrm{bar}^{-1}$ lett. Ezt többszörös és magasabb hőmérsékletű mosással sem lehetett eltávolítani, így ez egy állandó eltömődésnek tekinthető. Az adott hőmérséklet állandóságát biztosítva, és az ioncserélt víz dinamikai viszkoztását $\eta_{\mathrm{w}}=10^{-3}$ Pas értéken rögzítve, a transzmembrán nyomáskülönbséget 1,5 bar-nak véve, a membrán ellenállását $20^{\circ} \mathrm{C}$-on $1,44 \times 10^{12} \mathrm{~m}^{-1}$ értéknek számítottam. Miután a kezelt meggylevet a kísérleti berendezésből eltávolítottam, és desztillált vízzel átöblítettem, az eltömődési ellenállás számítható volt, mivel így eltávolítottam a polarizációs réteget, lehetővé téve az eltömődés egyszerü vizsgálatát. A számítások alapján ez az érték $1,1 \times 10^{13} \mathrm{~m}^{-1}$-nek adódott, mely összehasonlítva a membrán ellenállással egy nagyságrenddel nagyobb érték.

Végül az előző két ellenállás ismeretében visszaszámolható polarizációs réteg ellenállása is. A meggylé dinamikai viszkozitását $\eta_{\text {meggylé }}=1,3 \times 10^{-3}$ Pas értékkel közelítettem, amely megegyezik a megegyező koncentrációjú szacharóz oldat dinamikai viszkozitásával. Mivel a meggylé mikroszüréses tükrösítése 1,5 bar-on, $20^{\circ} \mathrm{C}$-on történt, de a permeátum fluxusa folyamatosan csökkent, a folyamat végére jellemző permeátum fluxust felhasználva számoltam a polarizációs réteg ellenállását. Ennek értéke $1,24 \times 10^{13} \mathrm{~m}^{-1}$ értéke volt. A három értéket összegzően a 54. ábra szemlélteti. 


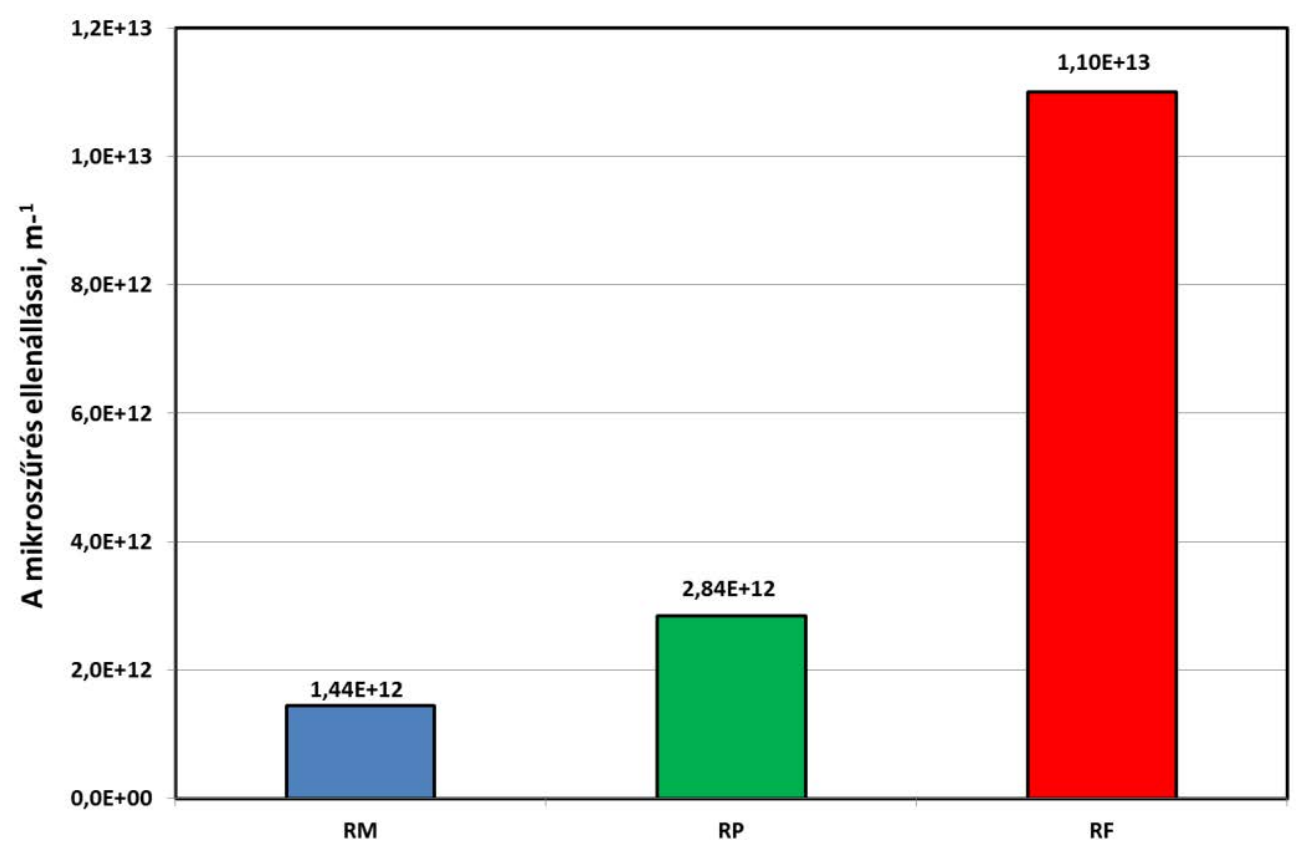

54. ábra A meggylé mikroszürésének ellenállásai $20^{\circ} \mathrm{C}$-on, 1,5 bar transzembrán nyomáskülönbség és $Q_{\text {rec }}=.500 \mathrm{~L} \mathrm{~h}^{-1}$ üzemeltetési térfogatáram mellett $\left(\mathrm{R}_{\mathrm{M}}\right.$-membrán ellenállása, $\mathrm{R}_{\mathrm{P}}$ ploarizációs réteg ellenállása, $R_{F}$ - eltömődési ellenállás)

Az 54. ábrán bemutatott ellenállások összege a folyamat során összesen fellépő ellenállás. Az $\mathrm{R}_{\mathrm{M}}$ gyakorlatilag azon eltömődési ellenállásokat jelenti egyben, melynek egy részét a tisztítási procedúrával sikeresen el lehet távolítani, más részük állandó eltömődésként továbbra is fennmaradtak. Ezek eltávolítására létezik eljárás, kemencében való hevítéssel a kemármia anyagában nem történik károsodás magas hőtürése miatt, viszont a szerves eltömődése elég, elporlad. Ebben az esetben ezt a hevítést nem tudtam kivitelezni, így ezzel a maradó eltömődéssel számolni kell.

$\mathrm{Az}$ 55. ábra mutatja a folyamat kiindulási szürletfluxusra vonatkoztatott átlagos fluxuscsökkenések arányát, azok okaival feltüntetve. Láthatjuk, hogy a folyamat során összesen fellépő fluxuscsökkenés gyakorlatilag több mint 90\%-os volt, és ennek oka alapvetően az eltömődés. A polarizációs hatás mindössze 5\%-ot tett ki ebböl. Az alapos mosás hatására az eltömődés 35\%-át meg lehetett szüntetni, de még így is jelentős, 45\%-os maradó eltömődésési fluxuscsökkenési hatást lehetett kimutatni. 


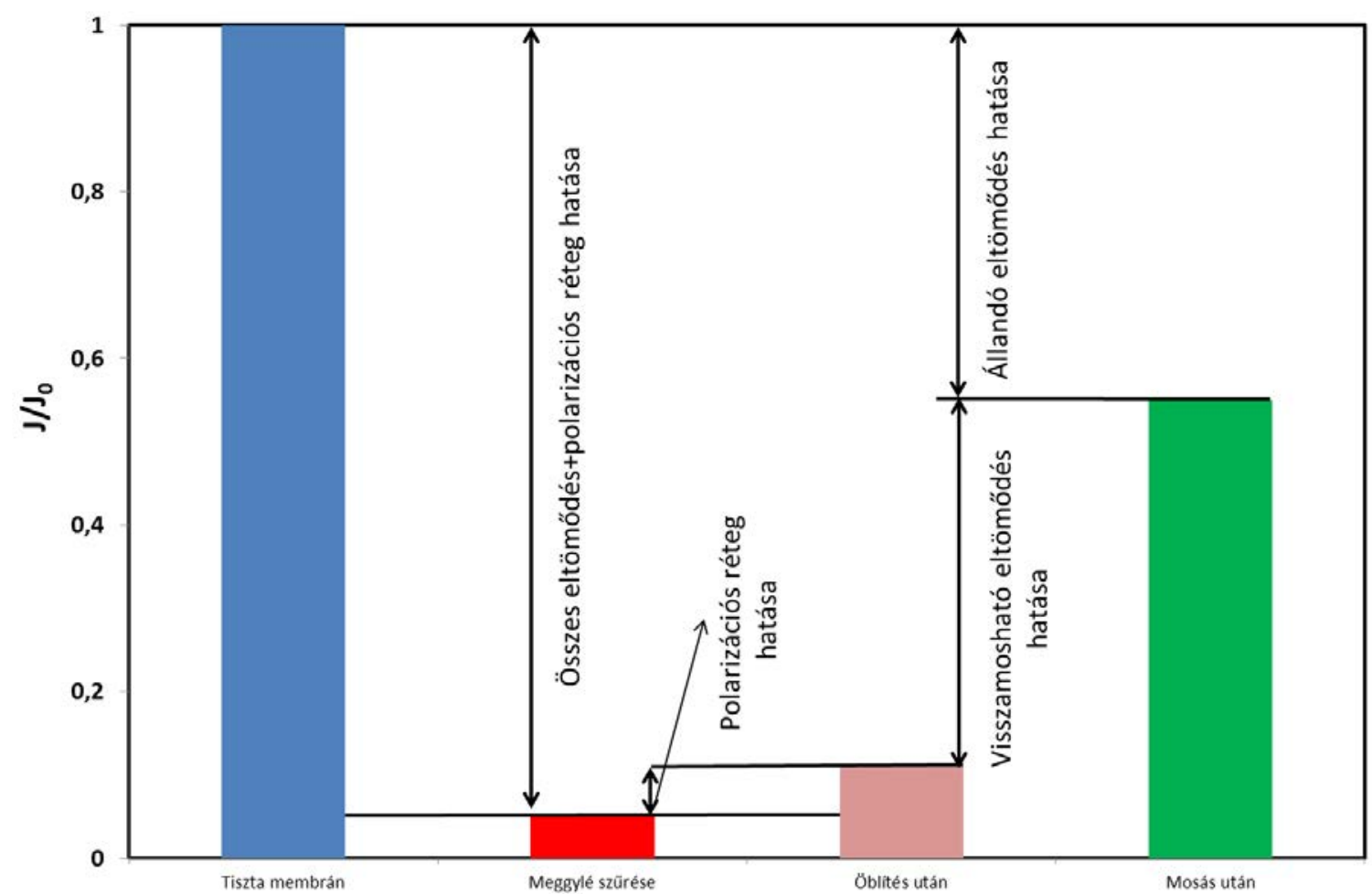

55. ábra A különböző ellenállások fluxuscsökkentő hatása

A mikroszürés az adott üzemeltetési paraméterek mellett képes volt az összcsíraszámot 1,9x10 1 értékről 0-ra csökkenteni, az élesztő és penész számot pedig $1 \times 10^{2}$-ről $<1 \times 10^{2}$ értékre csökkenteni, ami a kimutathatósági határ alatt volt. A 11. táblázat a mikroszürés csírátlanítási hatását mutatja be. Észrevehető, hogy a betáplálás kiindulási 19 telepe a 3,5 órás kezelés alatt a visszamaradó retentátumban 23 db-ra emelkedett. Ez betudható mind a koncentrálódás, mind pedig a szaporodási hatásnak. Viszont az egyértlemüen szembetünik, hogy a termékben, azaz a szürletben $0 \mathrm{db}$ telep fejlődött ki, ami egyértelmü jele a sikeres csírátlanításnak. Az élesztő és penészszámra is ez a jellemző, ott is sikeresen, a szabvány szerinti kimutatható érték alá sikerült $\left(<1 \times 10^{2}\right)$ csökkeneti a mikroorganizmusok jelenétét.

11. Összcsíra, élesztő és penészszám meghatározás eredményei

\begin{tabular}{|l|c|c|c|}
\hline Minta & Hígítás & Összcsíraszám (cfu/ml) & Élesztő és penész (cfu/ml) \\
\hline Betáplálás $(\mathrm{t}=0 \mathrm{~h})$ & 0 & $1,9 \times 10^{1}$ & $1 \times 10^{2}$ \\
\hline Sürítmény $(\mathrm{t}=3,5 \mathrm{~h})$ & 0 & $2,3 \times 10^{1}$ & $3 \times 10^{2}$ \\
\hline Szürlet $(\mathrm{t}=0 \mathrm{~h})$ & 0 & 0 & $<1 \times 10^{2}$ \\
\hline
\end{tabular}




\subsubsection{Meggylé elősürítése fordított ozmózissal spirál tekercs modullal}

A tükrösített és hidegen csírátlanított mikroszürésből érkező meggylevet fordított ozmózisos eljárással sürítettem tovább. Ennek célja alapvetően az ozmotikus desztillációs vizsgálatokhoz szükséges magasabb koncentráció elérése volt. A folyamatosan növekvő szénhidrát és egyéb oldott alkotók koncentrációjának függvényében a fordított ozmózisos folyamata egyre nagyobb energiabefektetést igényel, továbbá egyre jelentősebb lehet az értékes anyagok permeációja a membránon keresztül, ami veszteséget jelent.
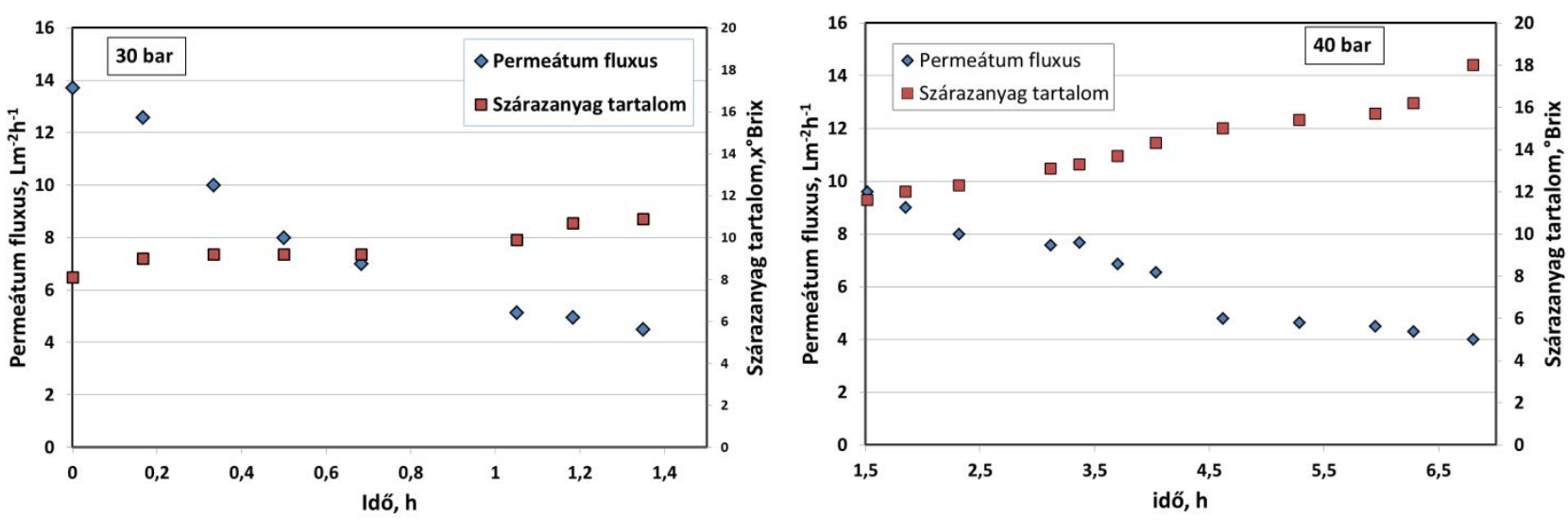

56. ábra Meggylé elősürítése fordított ozmózissal $\left(30^{\circ} \mathrm{C}, 500 \mathrm{Lh}^{-1}\right)$

A mủvelet során a kiindulási 5,8 ${ }^{\circ}$ Brix szárazanyag tartalmat sikeresen, egészen $18^{\circ}$ Brix értékre tudtam süríteni. A 56. ábra mutatja, hogy ezt a folyamatot két lépésben sikerült véghezvinnem, mivel a kezdeti, 30 bar transzmembrán nyomáskülönbség mellett kevesebb, mint 1,4 óra alatt a kiindulási $13,71 \mathrm{Lm}^{-2} \mathrm{~h}^{-1}$-ről 4,51 $\mathrm{Lm}^{-2} \mathrm{~h}^{-1}$-re csökkent a fluxus, és a szárazanyag tartalom mindössze $5,8^{\circ}$ Brix-röl $10,9^{\circ}$ Brix-re nőtt. Ezután a hajtóerőt 40 bar értékre növeltem, így sikerült további 5,4 óra alatt 10,9³rix-röl $18,0^{\circ}$ Brix-re, mialatt a 9,6 $\mathrm{Lm}^{-2} \mathrm{~h}^{-1}$-ról $4 \mathrm{Lm}^{-2} \mathrm{~h}^{-1}$-ra csökkent a fluxus értéke.

A 57. diagram a vízfluxus müvelet előtti és müvelet utáni értékeit mutatja. Jól látszik, hogy teljes mértékben sikerült a tisztítási procedúra, nem maradt fennt állandó eltömődési jelenség. 


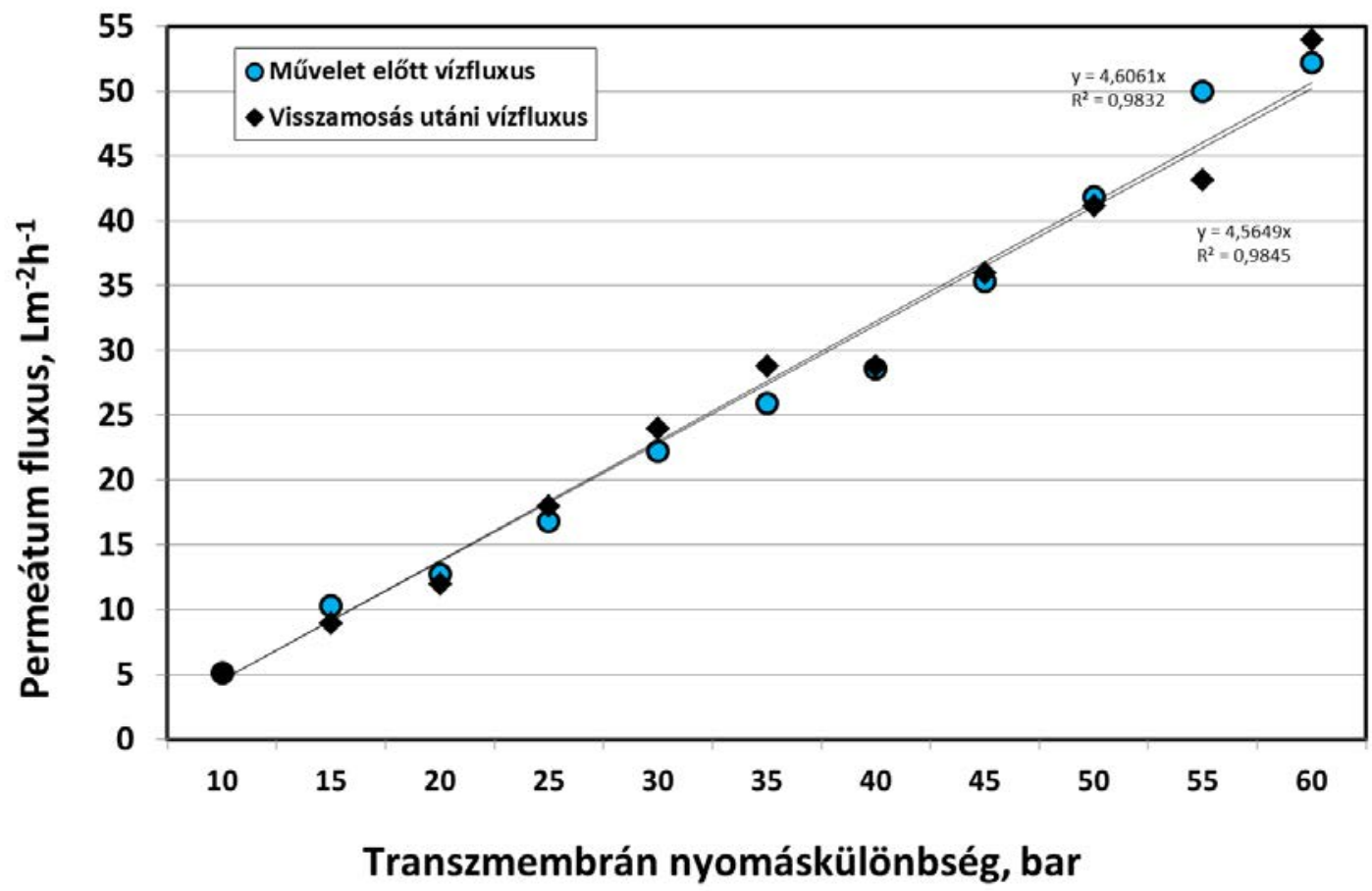

57. Vízfluxus az RO müvelet elött és mosás után $\left(30^{\circ} \mathrm{C}, 500 \mathrm{~L} / \mathrm{h}\right)$

\subsubsection{Meggylé elősürítése fordított ozmózissal, lapmembrán modullal}

A kísérleteket lapmembrán modulon is elvégeztem, hogy összehasonlítsam a spiráltekercs modullal elvégzett eredményekkel. A 58. ábra mutatja, hogy a szakaszos folyamat során a kiindulási $5,8^{\circ}$ Brix koncentrációt 4,1 óra alatt $15,6^{\circ}$ Brix értékre sikerült süríteni, míg a fluxus $7,4 \mathrm{Lm}^{-2} \mathrm{~h}^{-1}$-ról $3,1 \mathrm{Lm}^{-2} \mathrm{~h}^{-1}$-ra csökkent.

A 59. ábrán megfigyelhetjük a lapmembrán fordított ozmózis rendszer vízzel szembei viselkedését a meggysürítési procedúra előtt és utána. A megadott mosási procedúra elvégzése után is maradt egy kisebb eltömődés a membránon, mely esetleges, 0,45 $\mu$ m-nél kisebb sejtalkotókból, illetve óriás molekulákból származhat. 


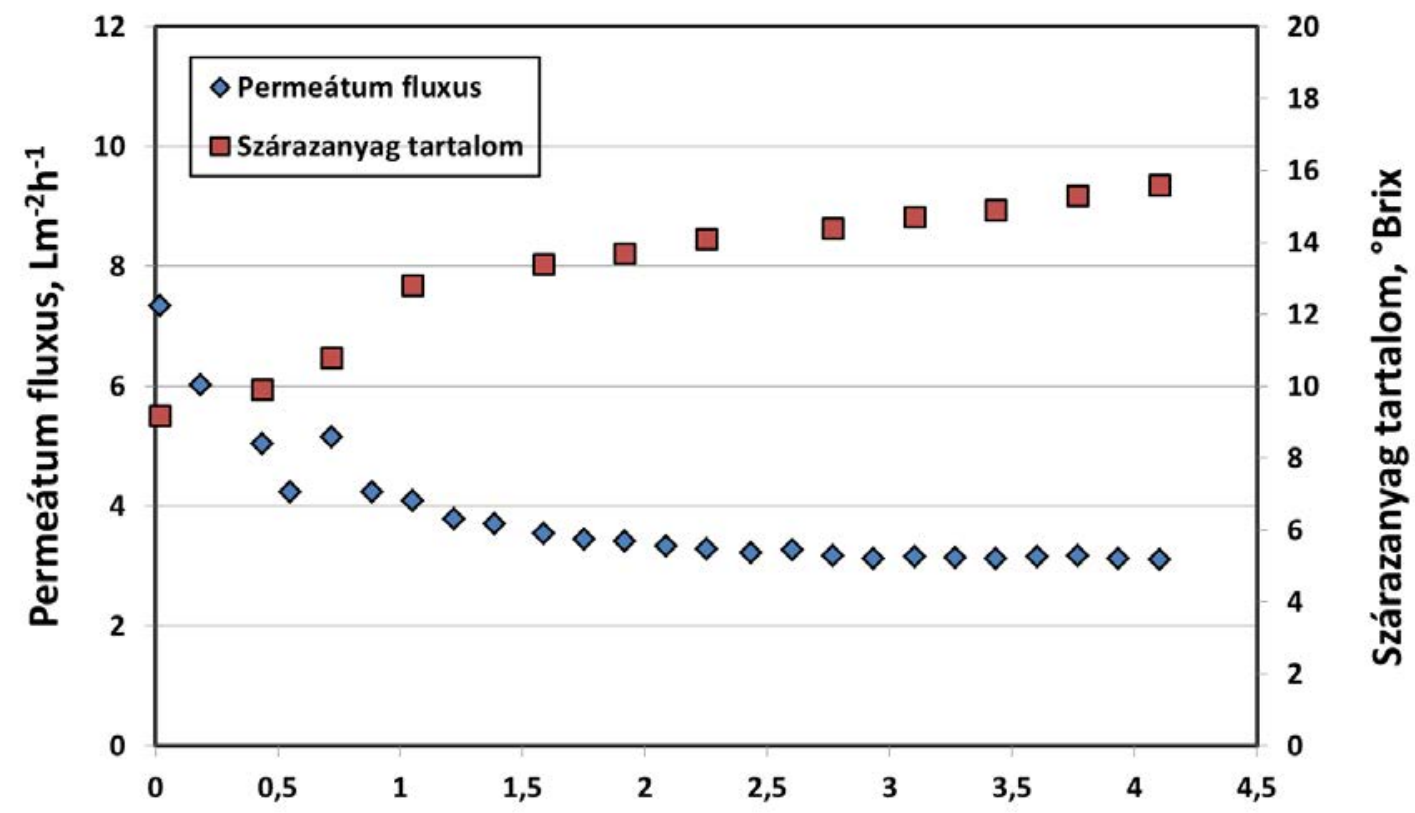

Idő, $\mathbf{h}$

58. ábra Meggylé elősürítése lapmembrán fordított ozmózissal $\left(20\right.$ bar, $\left.30^{\circ} \mathrm{C}, 500 \mathrm{~L} / \mathrm{h}\right)$

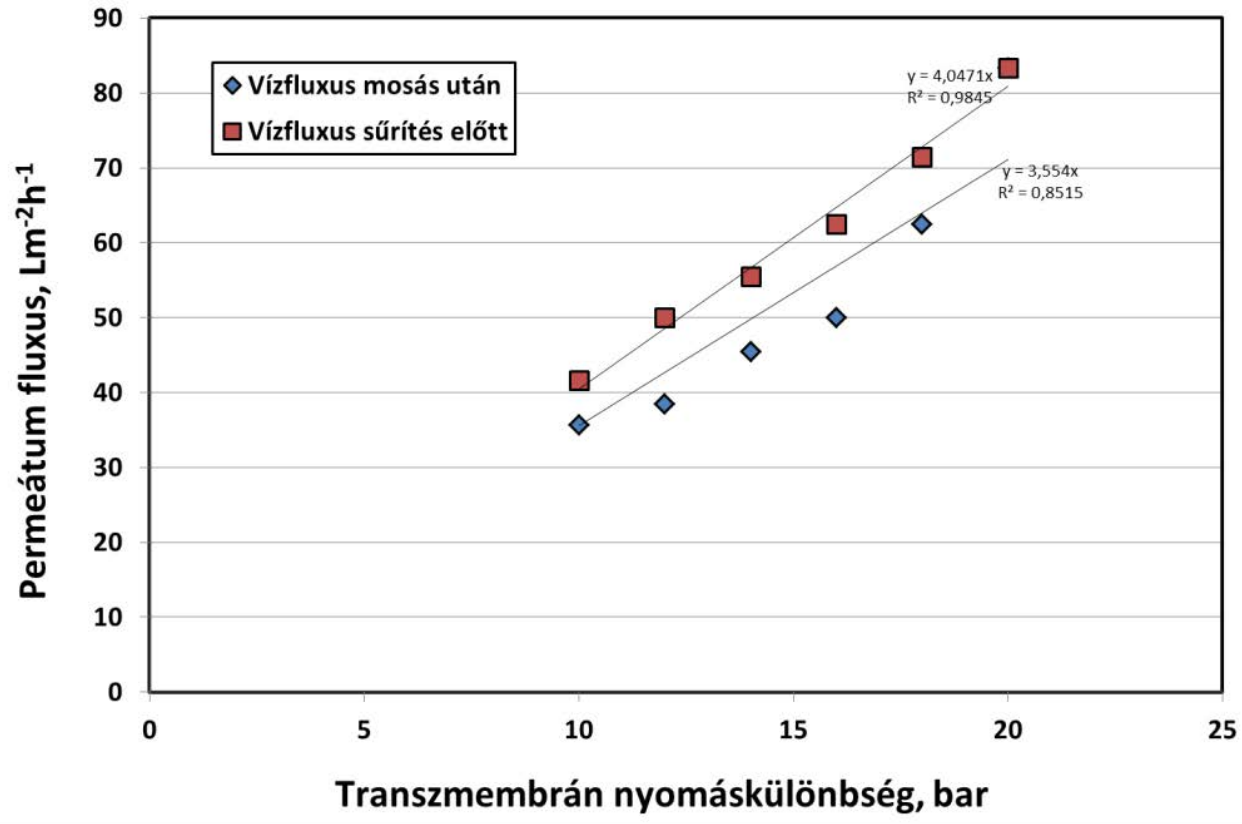

59. ábra Lapmembrán fordított ozmózis vízfluxusa a meggysűrtés előtt és után, a megfelelő mosási procedúrát követően $\left(30^{\circ} \mathrm{C}, 500 \mathrm{~L} / \mathrm{h}\right)$ 


\subsubsection{Meggylé koncentrálása ozmotikus desztillációval}

Az előkísérletek alapján megvizsgáltam a négy leghatékonyabbnak bizonyult ozmotikus oldattal való sürítés fluxusait, a 60. ábra mutatja ennek eredményét. Minden esetben a kiindulási oldat közel telített ozmotikus oldat volt, és a meggysürítmény kiindulási száraznyag-tartalma a fordított ozmózisos elősürítés $18,0^{\circ}$ Brix értéke volt. A folyamatot szakaszos körülmények között hajtottam végre, ennek okán figyelhető meg a folyamatos fluxuscsökkenés.

Jól látható, hogy a vártaknak megfelelően a legnagyobb fluxust a $\mathrm{CH}_{3} \mathrm{COOK}$ oldattal történő üzemeltetés eredményezte. Ezután következett a $\mathrm{CaCl}_{2}$, majd pedig az $\mathrm{NH}_{4} \mathrm{NO}_{3}$ és végül a $\mathrm{K}_{2} \mathrm{CO}_{3}$ oldatos sürítés.

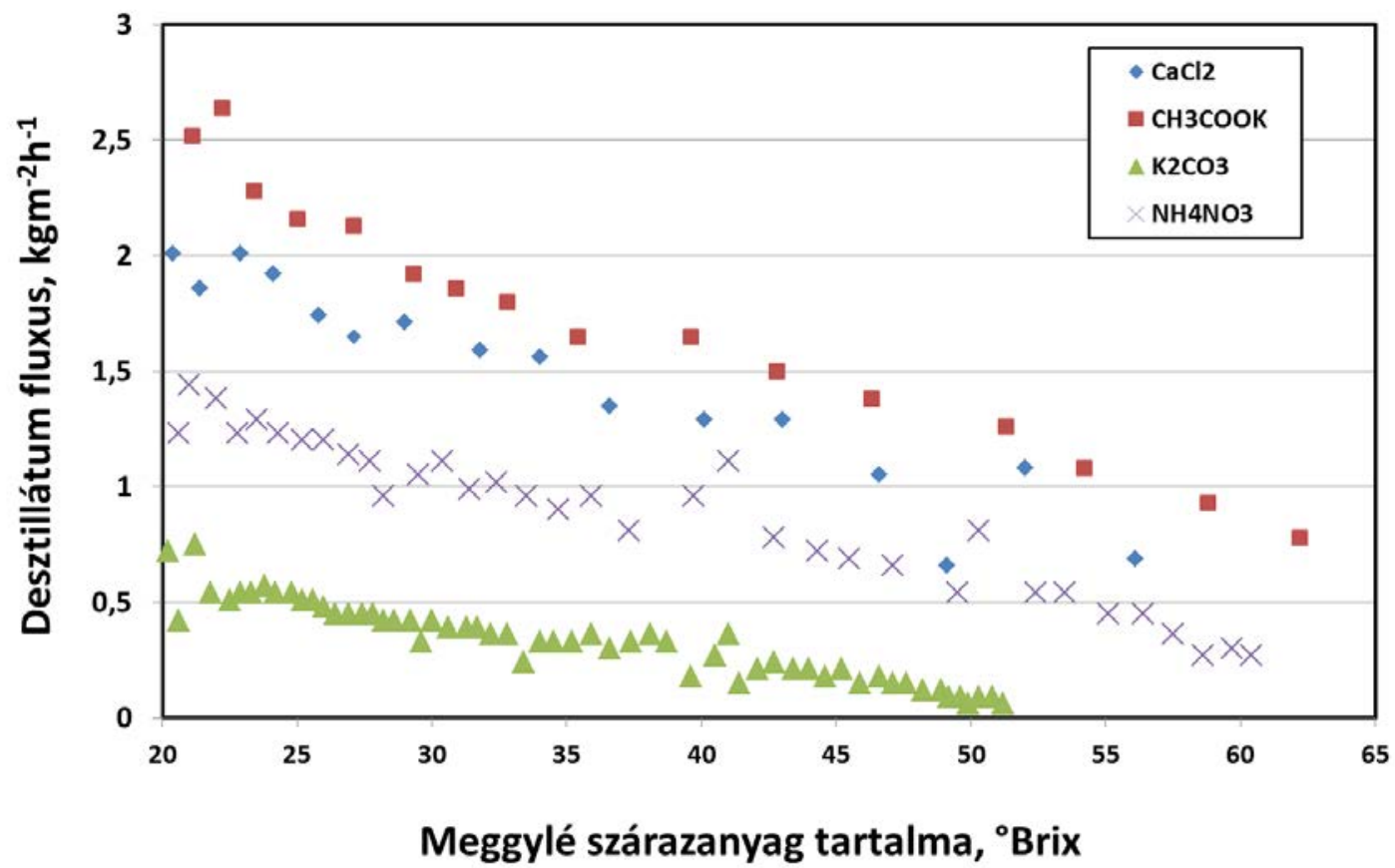

60. ábra Ozmotikus desztilláció különböző ozmotikus oldatokkal $\left(30^{\circ} \mathrm{C}, Q_{\text {betáp }}=22 \mathrm{~L} / \mathrm{h}\right)$

A legmagasab végsürítési értéket a $\mathrm{CH}_{3} \mathrm{COOK}, \mathrm{CaCl}_{2}$ és $\mathrm{NH}_{4} \mathrm{NO}_{3}$ oldatokkal sikerült elérnem, mindhárom esetben nagyobb, mint $60^{\circ}$ Brix végkoncentrációt. $\mathrm{CH}_{3} \mathrm{COOK}$ esetében $62,5^{\circ}$ Brix értéket sikerült elérnem, és ez bizonyult a legnagyobb értéknek. 
A 61. ábra mutatja a vízaktivitási értékeket, valamint a gőznyomás értékeket a kiválasztott két ozmotikus ágens, és a meggylé összetételének függvényében.

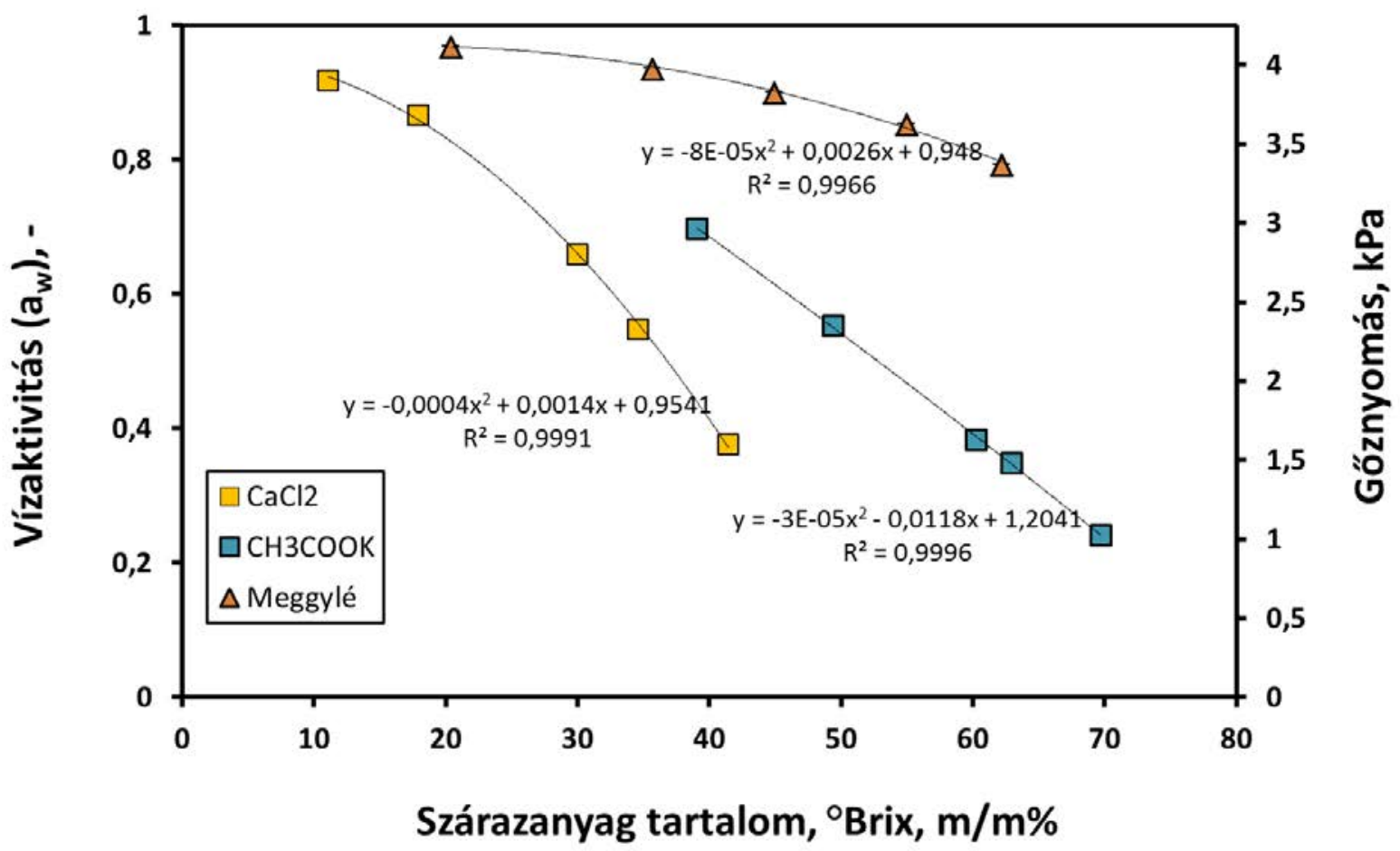

61. ábra $\mathrm{CH}_{3} \mathrm{COOK}, \mathrm{CaCl}_{2}$ és a meggylé vízaktivitás és vízgőznyomás értéke a koncentráció függvényében $\left(30^{\circ} \mathrm{C}\right)$

$\mathrm{Az}$ ábrán jól megfigylehető, hogy a $\mathrm{CH}_{3} \mathrm{COOK} 70 \mathrm{~mm}^{-1} \%$-os értékéhez tartozik a legkisebb vízaktivitás $(0,24)$, és ezáltal vízgőznyomás $(1,03 \mathrm{kPa})$ érték, az adott hőmérsékleten $\left(30^{\circ} \mathrm{C}\right)$. Ezzel szemben a $\mathrm{CaCl}_{2}$ oldat adott höméréskleten elérhető legalacsonyabb vízaktivitás értéke 0,34 , ami $1,60 \mathrm{kPa}$ értéknek felel meg gőznyomás tekintetében.

Az ábrán az is megfigyelhető, hogy a $\sim 20^{\circ}$ Brix kiindulási meggylé vízaktivitása 0,93 , és a végsürítmény $62,2^{\circ}$ Brix értéke mellett 0,79 vízaktivitás értéket lehetett megállapítani. Ettől az értéktől magasabb értéken a müveletet korlátozott mértékben lehet kivitelezni, mivel a meggysürítmény dinamikai viszkozitás értéke szintén drámaian megnő (M.VII.). Így, az anyagátbocsátási jelenségek magyarátánál és leírásánál figylelembe kell vennünk a dinamikai viszkozitás változásának szerepét, mivel a két ozmotikus ágens dinamikai viszkoztása más értékeket vesz fel a koncentráció függvényében. 
A 62. ábra mutatja, hogyan változik a hajtóerő a sürítés folyamán a $\mathrm{CH}_{3} \mathrm{COOK}$ és $\mathrm{CaCl}_{2}$ oldatok esetében, a meggylé szárazanyag-tartalmának függvényében.

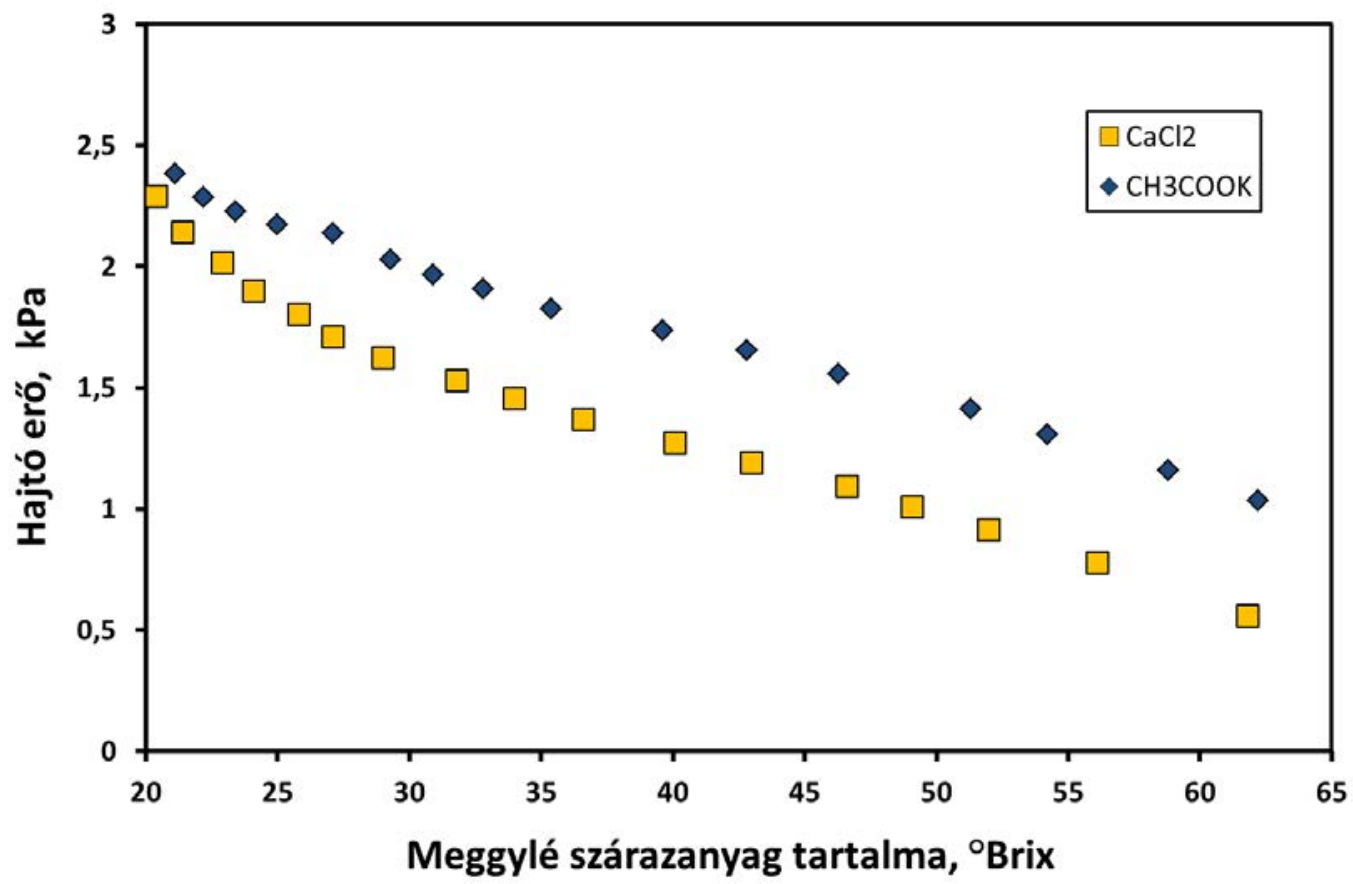

62. ábra Az ozmotikus desztilláció hatjóerejének változása a meggylé szárazanyag-tartalmának függvényében, a koncentrálás során

Az ábra alátámasztja azt a feltételezést, hogy a fluxusbeli különbségek alapvetően a létesíthető hajtóerő-különbségeből erednek, és mivel a $\mathrm{CH}_{3} \mathrm{COOK}$ oldattal magasabb érték állítható elö, alapvetően ez a hatás indukálja a hatékonyabb anyagátbocsátást.

Az irodalmi áttekintés és anyagok és módszerek fejezetekben feltüntetett összefüggések alapján a fluxusok és a hajtóerő függvényében egyszerüen ki lehet számítani az anyagátbocsátási együttható értékét mind a két ozmotikus oldat esetében, ezt mutatja az 63. ábra. Látható, hogy nagyságrendileg megegyező értékeket kaptam $\left(2-3 \times 10^{-7} \mathrm{kgm}^{-2} \mathrm{~s}^{-1} \mathrm{~Pa}^{-1}\right)$, habár az alacsonyabb hajtóerők mellett az anyagátbocsátási tényező értéke magasabb volt a $\mathrm{CaCl}_{2}$ esetében, mint a $\mathrm{CH}_{3} \mathrm{COOK}$ esetében.

Ez a jelenség azzal magyarázható, hogy habár a gőznyomás értékek megegyeznek ilyenkor minkét ozmotikus oldat esetében, de az adott összetételhez tartozó dinamikus viszkozitások eltérőek lehetnek, mely kihat az ozmotikus oldat oldali anyagátadási tényező értékére. 


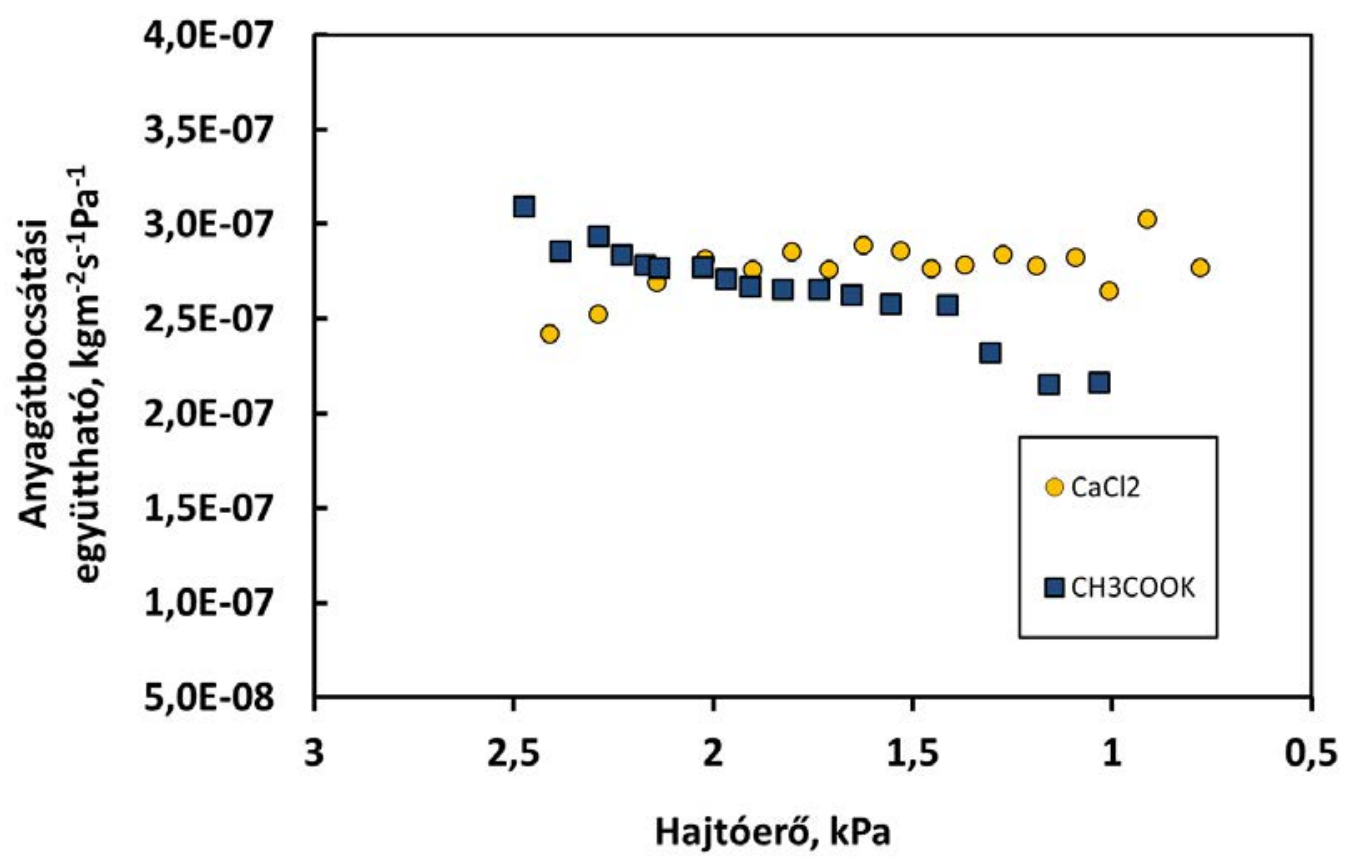

63. ábra $\mathrm{Az}$ anyagátbocsátási tényező értéke a meggysürítés folyamán $\mathrm{CH}_{3} \mathrm{COOK}$ és $\mathrm{CaCl}_{2}$ oldatokkal

$\mathrm{Az}$ 63. ábra azt is mutatja, hogy magasabb koncentráció tartományban az $\mathrm{CH}_{3} \mathrm{COOK}$ hatékonyabban müködik, mint a $\mathrm{CaCl}_{2}$ oldat. Ezt megjeleníthetjük úgy is, hogy a fluxusokat a telítettségi állapotukhoz képest hasonlítjuk össze (64. ábra). Az ábrán látható, hogy a $\mathrm{CaCl}_{2}$ oldat esetében a kiindulási ozmotikus oldat közel telített volt (95\%), míg a $\mathrm{CH}_{3} \mathrm{COOK}$ esetében ez mindössze $83 \%$ volt. Ez annak tudható be, hogy a $\mathrm{CH}_{3} \mathrm{COOK}$ oldat sokkal kisebb mennyiségü víz hatására lesz kevésbé telített, felhígul, így a berendezés holtteréből felvett víz ebben az esetben a rendelkezésre álló oldat mennyiséghez képest jóval nagyobb hígulást eredményezett. 


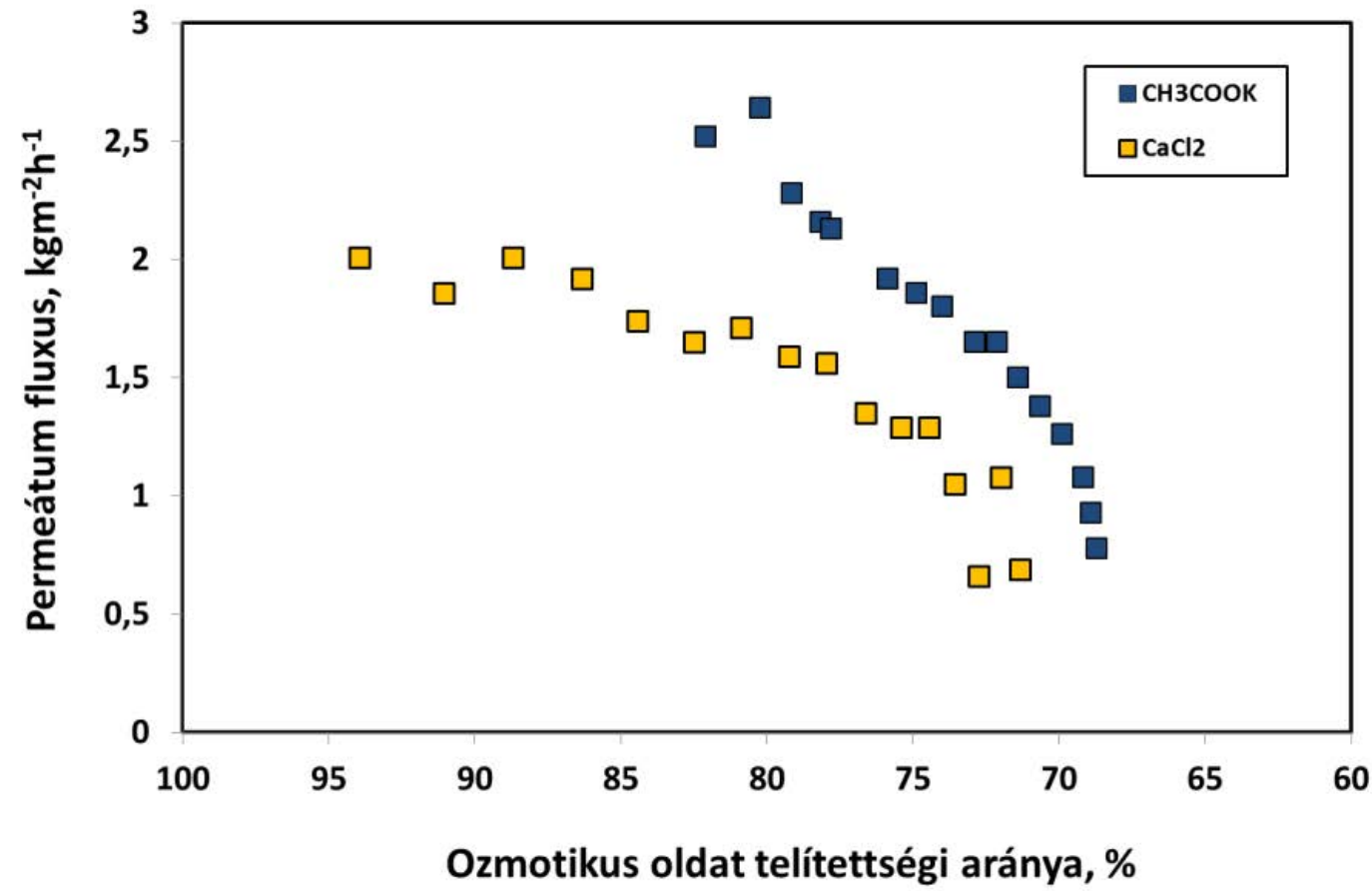

64. ábra Meggysürítés fluxusai az ozmotikus oldatok telítettségének függvényében

Ettől függetlenül kijelenthető a 63. és 64. ábrák alapján, hogy a $\mathrm{CH}_{3} \mathrm{COOK}$ akkor tud hatékonyan müködni egy folytonos rendszerben, ha a folyamatos regenerálást úgy oldjuk meg, hogy nem engedjük felhígulását $80 \%$ alá, így a $\mathrm{CaCl}_{2}$ oldathoz képest folyamatos fluxustöbbletet tudunk generálni, ezzel biztosítva a hatékony üzemeltetés körülményeit.

\subsubsection{Meggylé analitikai vizsgálata}

A következő fejezetben a meggylé összpolifenol és antioxidáns kapacitásának mérési eredményeit mutatom be, és azt, hogy a különböző eljárások milyen hatással voltak ezek koncentrációjára. A 65. ábra a különböző állapotok összes polifenol és összes antioxidáns kapacitását szemlélteti. 


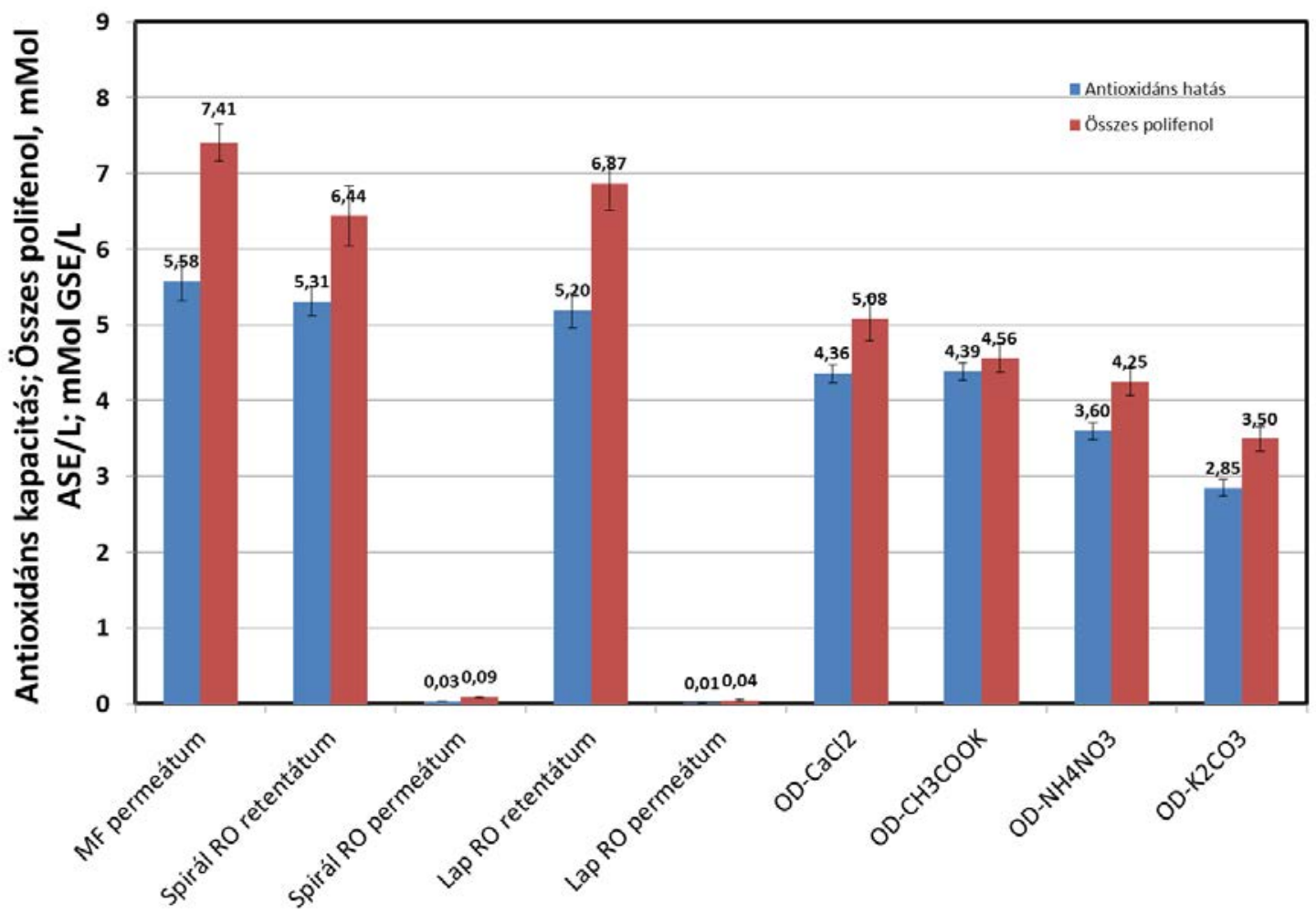

65. ábra A meggysürítés különböző állapotainak antioxidáns és összes polifenol értékei

Az ábrán megfigyelhető, hogy a sürítés a sürítmények összes polifenoltartalma és antioxidáns hatása a visszahígított meggylevek esetében csökkenést eredményezett. A mérések azt mutatják, hogy az összes polifenol tartalmat illetően a $\mathrm{CaCl}_{2}$ bizonyult a leghatásosabbnak, ezt követte a $\mathrm{CH}_{3} \mathrm{COOK}$ oldat, majd pedig az $\mathrm{NH}_{4} \mathrm{NO}_{3}$ és a $\mathrm{K}_{2} \mathrm{CO}_{3}$ oldattal való sürítés. Az ábrából az is egyértelmüen kitünik, hogy az RO permeátumban csak alig mérhetö értékesanyag tartalmat sikerült kimutatnom, ami a membrán magas visszatartását bizonyítja.

Ahhoz, hogy valóban megállapíthassam, történt-e szignifikáns változás a vizsgált paramétereket illetően, a sürítési arányokkal korrigált, „visszahígított” értékeket is meg kell, hogy vizsgáljam. Ezek után Games-Howell statisztikai elemzés útján megállapítható $(\alpha=0,05)$, hogy történt-e a müveleti lánc bármelyik részében értékesanyag veszteség.

Az 66. és 67. ábra az antioxidáns hatás és az összes polifenoltartalom értékeit mutatja. Homogenitás és normalitás vizsgálat után Games-Howell robusztus statisztikai módszer segítségével határoztam meg azt, hogy a kiindulási meggyléhez képest a müvelet mely fázisában jelentkezik szignifikáns csökkenés. 


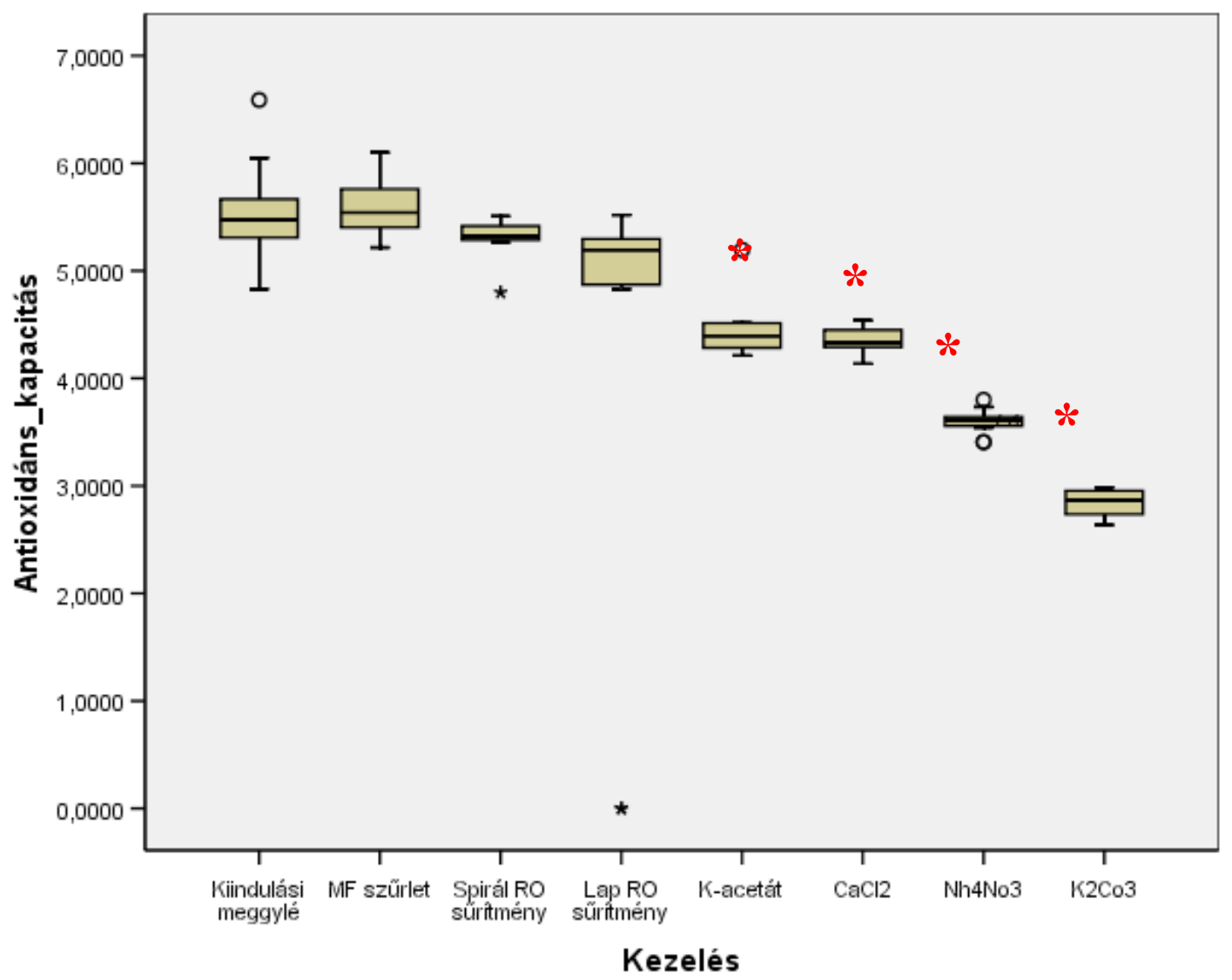

66. ábra Antioxidáns kapacitás változása a müveleti lépések során, jelölve a szignifikáns eltéréseket a kiindulási meggylé értékéhez képest $(\alpha=0,05)$

Az 66. ábra azt mutatja, hogy az antioxidáns hatásra egyik elökezelésnek (mikroszürés, fordított ozmózis lapmembránnal, spirál tekercs modull) sem volt szignifikáns hatása. Ezzel szemben az ozmotikus desztillációs vizsgálatok esetében szignifikáns csökkenést találtam. A M.VIII. mellékletben látható, hogy bár a K-acetát alkalmazása is szignifikáns hatást generált, de a négy különböző ozmotikus oldat tekintetében ez eredményezte a legkisebb eltérést. 


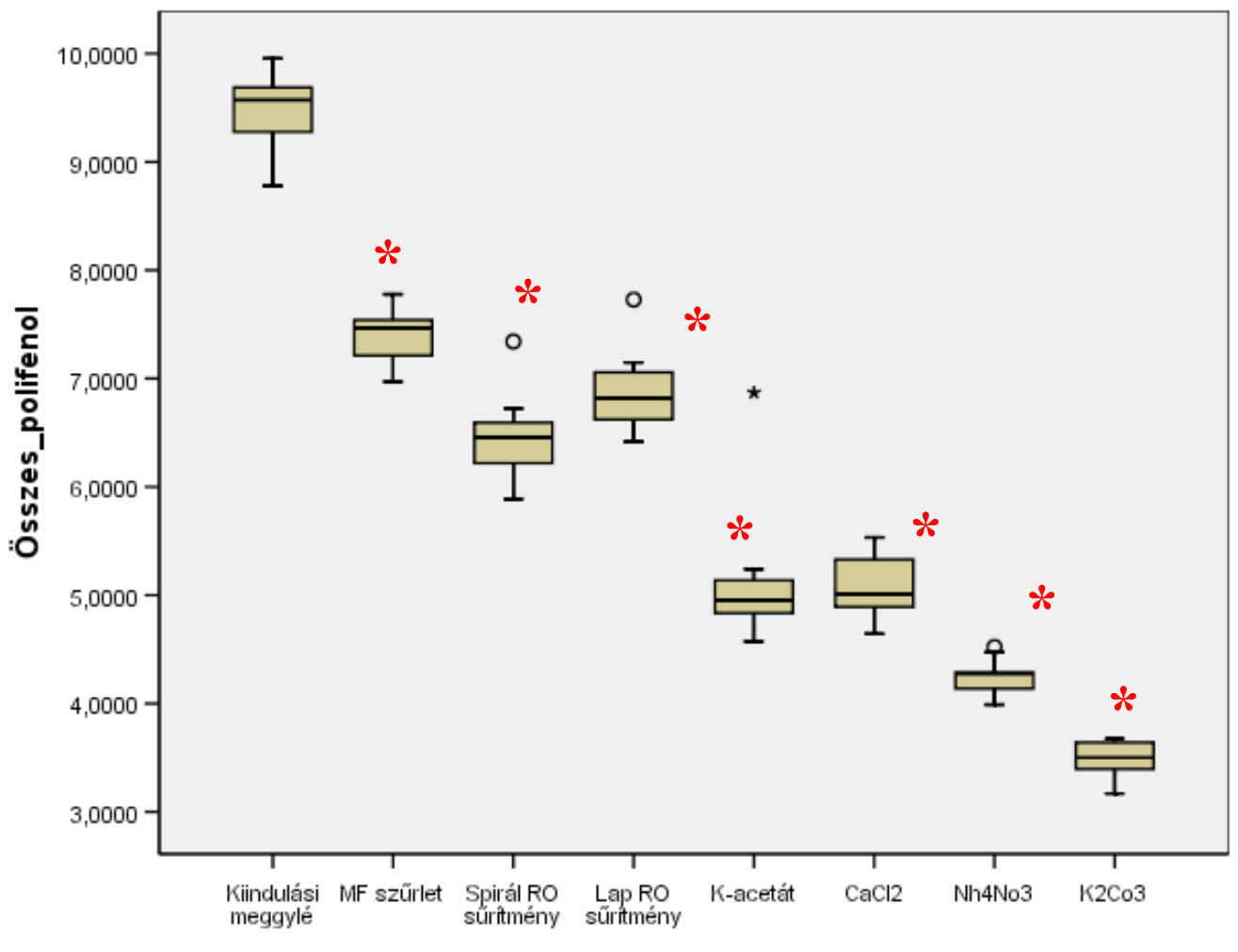

Kezelés

67. ábra Antioxidáns kapacitás változása a műveleti lépések során, jelölve a szignifikáns eltéréseket a kiindulási meggylé értékéhez képest $(\alpha=0,05)$

Az 67. ábra azt mutatja, hogy az összes polifenol tartalmat tekintve már a mikroszürés is szignifikás eltérést eredényezett. Ennek következményeként az ezeket követő lépések már alapvetően szignifikánsan el kell, hogy térjenek a kiindulási meggylé összes polifenol tartalmától.

A 12. táblázat szemlélteti a további múveleti lépések közti viszonyokat. Jól látható, hogy ebben az esetben mindkét fordított ozmózis esetében volt szignifikáns eltérés, viszont a két módszer között nem volt statisztikai különbség. A spirál tekercs modullal elvégzett fordított ozmózisos, és a lapmembrán modullal elvégzett fordított ozmózisos eljárás után elvégzett bármelyik ozmotikus desztillációs módszernél találtam szignifikáns eltérést, bár a $\mathrm{CH}_{3} \mathrm{COOK}$ és $\mathrm{CaCl}_{2}$ oldatokkal végzett sürítések között nem volt szignifikáns különbség. A legnagyobb csökkenést a $\mathrm{NH}_{4} \mathrm{NO}_{3}$, és végül a $\mathrm{K}_{2} \mathrm{CO}_{3}$ ozmotikus oldatok jelentették. 
12. táblázat Szignifikáns hatások az összes polifenol tartalom tekintetében $(\alpha=0,05)$

\begin{tabular}{|l|c|c|}
\hline MF & Spirál RO & $*$ \\
\hline Spirál RO & Lap RO & $*$ \\
\hline Spirál RO & $\mathrm{Lap} \mathrm{RO}$ & 0 \\
\hline & $\mathrm{CH}_{3} \mathrm{COOK}$ & $*$ \\
& $\mathrm{CaCl}_{2}$ & $*$ \\
\hline$\underline{\text { Lap RO }}$ & $\mathrm{NH}_{4} \mathrm{NO}_{3}$ & $*$ \\
& $\mathrm{~K}_{2} \mathrm{CO}_{3}$ & $*$ \\
& $\mathrm{CH}_{3} \mathrm{COOK}$ & $*$ \\
\hline$\underline{\text { CH}}$ COOK & $\mathrm{CaCl}_{2}$ & $*$ \\
& $\mathrm{NH}_{4} \mathrm{NO}_{3}$ & $*$ \\
\hline
\end{tabular}

A 68. ábra az ozmotikus desztillációs sürítések hatását szemlélteti az antioxidáns hatásra, és az összes polifenol tartalomra a müveleti idő függvényben. Az ábráról egyértelmüen megállapítható, hogy a hosszabb müveleti idő nagyobb értékes komponens veszteséget jelentett. Ez arra utalhat, hogy az értékes komponensek egy része a folyamat során elbomlik, vagy a hőmérséklet, vagy a levegő oxigéntartalma, vagy a fény, vagy pedig mindhárom tényező hatására.

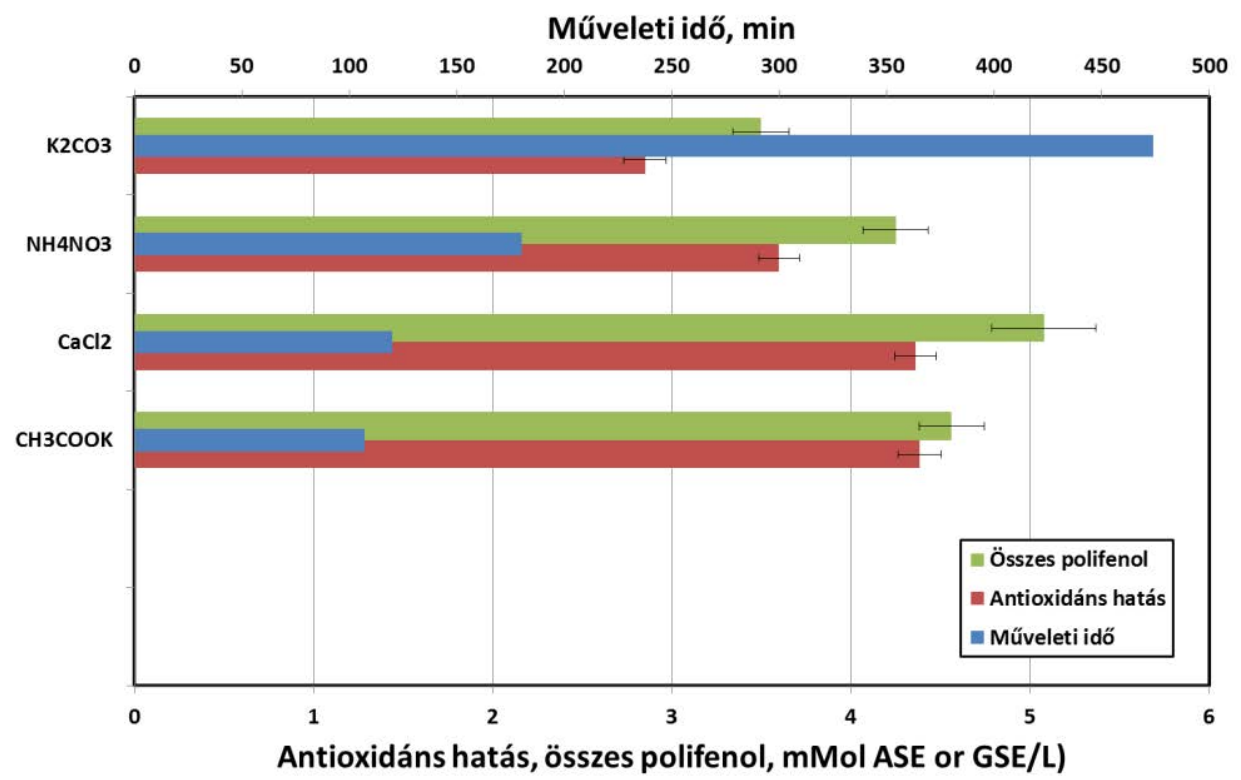

68. ábra Értékes komponensek tartalmának változása az ozmotikus desztillációs vizsgálatok során, a müveleti idő függvényében 


\section{6. Új tudományos eredmények}

I. Új, dinamikus mérési módszert dolgoztam ki a folyadék behatolási nyomás ( $\left.\mathrm{LEP}_{\mathrm{w}}\right)$ mérésére közvetlen érintkeztetéssel (DCMD) és vákuummal megvalósított membrándesztillációs (VMD) konfigurációkban. Bizonyítottam, hogy a dinamikus módszer alkalmas az $\mathrm{LEP}_{\mathrm{w}}$ meghatározására ezekben a konfigurációkban. Azt is bizonyítottam a VMD konfigurációt tekintve, hogy a dinamikus módszerrel megállapított $\mathrm{LEP}_{\mathrm{w}}$ értéke alacsonyabb a statikus módszerhez képest, így a dinamikus módszer a desztillátum minősége szempontjából egy szigorúbb műveleti korlátot eredményez a statikus módszerrel szemben, amelynek tudatában magasabb desztillátum minőséget, ezálta müveleti üzembiztonság érhető el.

II. Új, vákuummal történő membránregenerálási eljárást dolgoztam ki lapmembrán esetére szendvics modulban elhelyezve, mely jelentősen megkönnyíti a pórusokban rekedt nedvesség eltávolítását anélkül, hogy a membránt a berendezésből el kellene távolítani.

III. Vákuum-membrándesztillációs (VMD) kísérleti berendezés segítségével bizonyítottam, hogy az olajkoncentrációnak nincs hatása a desztillátum fluxusára egy spontán nedvesedési pont eléréséig. Ez az érték a vizsgált membrán és müveleti körülmények esetében 250 ppm olajkoncentrációt jelentett. Továbbá itt is bizonyítást nyert az, miszerint a dinamikus módszerrel megállapított LEP értékek alacsonyabbak a statikus módszer segítségével megállapított értékektől.

IV. Új, eddig még kevéssé, vagy egyáltalán nem vizsgált ozmotikus oldatokat alkalmaztam az ozmotikus desztilláció intenzifikálásának céljából, és a $\mathrm{CH}_{3} \mathrm{COOK}$ oldat bizonyult a leghatékonyabbnak. A következő regressziós modellt kaptam:

$$
J=0,8908+0,6019 \frac{C(\%)-62,5}{37,5}+0,1704 \frac{T\left({ }^{\circ} C\right)-37}{5}
$$

melynek érvényessége $\mathrm{T}_{\text {betáp }}=32-42^{\circ} \mathrm{C}, \quad \Delta \mathrm{T}=5-15^{\circ} \mathrm{C}$, ozmotikus oldat telítettsége $25-100 \%$ tartományban. 
V. A meggy értékes komponenseinek vizsgálata során bizonyítást nyert, hogy az összes polifenol tartalom tekintetében a fordított ozmózisos lapmembránnal és spiráltekercs modullal egyaránt szignifikáns értékesanyag-csökkenés vehető észre, az ozmotikus desztillációs kísérletek tekintetében szintúgy. Az antioxidáns kapacitás nem csökkent szignifikánsan sem a spirál, sem a lapmembrán alkalmazásával, de az ozmotikus desztilláció esetében itt is szignifikáns volt a csökkenés. Továbbá megállapítást nyert az is, hogy a csökkenés mértéke a $\mathrm{CH}_{3} \mathrm{COOK}$ esetében a legkisebb, ami a legrövidebb müveleti idővel van kapcsolatban. Ennek oka feltételezhetően a különböző fizikai behatásokra és ezen behatások hosszára vezethető vissza (fény, hőmérséklet, levegő oxigénjével való reakció).

VI. Többlépcsős membrántechnikát végeztem el eddig még nem vizsgált zsályakoncentrátum sürítésére. Munkám során bizonytást nyert, hogy a kezdeti $0,9 \mathrm{~m} / \mathrm{m} \%$ oldott szárazanyag-tartalmat az MF-RO-OD müveleti kapcsolás 32,4 m/m\% tudja süríteni. A munkám során arra is fény derült, hogy a fordított ozmózisos lépés 60\%-ban tartotta vissza az értékes komponenseket, az ozmotikus desztilláció viszont nagyobb több mint 90\%-ban. 


\section{KÖVETKEZTETÉSEK ÉS JAVASLATOK}

I. A membrándesztillációs müveletek esetében a kritikus LEP paraméter meghatározása dinamikus módszerrel, sokkal „valóságszerübb” információt biztosít, mint a hagyományos, irodalomban fellelhető statikus módszer. Egy ilyen müveleti feladat első lépéseként ennek a paraméternek a meghatározása elengedhetetlen a magasszintü üzembiztonság feltételének teljesítéséhez, és a dinamikus módszer erre kiválóan alkalmas.

II. A nedvesedett lapmembránpórusok vákuum segítségével regenerálhatóak, és így elkerülhető a hosszadalmas és költséges szerelés, újra üzembe helyezés. Viszont érdemes lenne az eljárás további vizsgálata, mégpedig speciális átlátszó modulok segítségével, ahol szemügyre vehető, nincs-e olyan hely a modulban, ahol a nedvesség panghat, ezáltal kialakítható egy olyan módszer (vákuum érték, áramlási sebesség, stb.), amiben az etanol pozitív hatása megmutatkozhat.

III. Olaj-víz emulziók szétválasztására a membrándesztilláció alkalmas, viszont kritikus tényező a megfelelő modulkialakítás, és hogy a betáplált elegy olajtartalma egy meghatározott, ún. kritikus koncentráció alatt legyen, ezzel elkerülve a pórusok spontán nedvesedésének lehetőségét. Ennek elkerülésére célszerü a rendszert folyamatos üzemben vizsgálni, ahol a rendszer a kritikus LEP értéke alatt üzemel. Egy ilyen folyamatos rendszer laboratóriumi vizsgálata szükséges lenne a továbbiakban.

IV. Zsályakivonat koncentrálása membrános müveletekkel egy ígéretes lehetőség, viszont a kritikus tényező a fordított ozmózis lépése, mely során jelentős értékes anyag csökkenés léphet fel. A megfelelő membrán és modulkialakítás felderítése további, részeltesebb kísérletezést igényel.

V. Az ozmotikus desztillációs kísérletek hatékony elvégzésére kíváló alternatíva lehet a $\mathrm{CH}_{3} \mathrm{COOK}$ oldat. Élelmiszeripari felhasználása lehetséges, így ez által kiváltható a visszasürítése, mivel termékként értékesíthető, vagy legalábbis csak egy részét szükséges regenerálni.

VI. A vizsgált koncentráció tartományban a hőmérséklet-különbség alkalmazása szignifikánsan nem növeli az OD hatékonyságát. Érdemes lenne tovább vizsgálni, vajon van-e olyan tartomány, melyben megjelenik ennek a szignifikáns hatása. 
VII. A kapcsolt membrán müveletek alkalmasak a meggylé sürítésére, viszont a megfelelő fordított ozmózisos membránok megtalálása, és az ozmotikus desztilláció során fellépő értékes anyag csökkenés alapvető oka még ismeretlen. Fontos lenne annak kiderítése, hogy ennek az oka a müveleti körülményektől, azon belül is mely hatásoktól függ leginkább és hogyan lehet a negatív hatást elkerülni. 


\section{7. ÖSSZEFOGLALÁS}

A membrán- és ozmotikus desztilláció az elkövetkezendő években jelentős szerephez juthat ipari méretekben is. Membrándesztillációs rendszereket már ma is kaphatunk, az ozmotikus desztilláció ipari méretben még nem megvalósított. Kísérleteim során azt a célt tartottam szem előtt, hogy minél több olyan eredmény szülessen, ami által megvalósítható az ipari méretü rendszerek kivitelezése. Munkám kétpólusú: a membrándesztilláció alapkutatáshoz kapcsolódó LEP és regenerálási vizsgálatok, valamint az ezekhez köthető olajos szennyvizek kezelésének lehetősége membrándesztillációval. Másik pólusként az ozmotikus desztilláció jelenik meg, és az ehhez kapcsolódó új ozmotikus oldatok vizsgálata, másrészről pedig ezek alkalmazása valós, meggylé és zsályakoncentrátum elkészítése céljából.

Elöremutató eredményeket kaptam mindkét pólus tekintetében. Az általam kidolgozott dinamikus LEP mérési módszer az irodalomban fellelhető módszerrel szemben alacsonyabb értékeket eredményezett, ami nagyobb körültekéntésre figyelmeztet bennünket az ipari megvalósítások tervezése és méretezése esetén.

A VMD eljárás egy megfelelő alternatíva lehet olajos szennyvizek szétválasztására, habár ehhez a membránok intenzívebb fejlesztése elengedhetetlen lesz a jövőben. Az átlalam kidolgozott LEP mérési módszer pedig valós képet mutat az üzemeltetőknek arról, hogy milyen keretek között tudják hatékonyan müködtetni a jövőben az ilyen rendszereiket, akár olajos fázist emulzió formájában tartalmazó betáplálások mellett is.

A zsályakivont értékes alkotóinak a koncentrálása többlépcsős membrános technikákkal (MF-RO-OD) összhangban az előző tapasztalatokkal, megvalósítható. Munkában viszont fény derült arra, hogy a RO lépés kritikus az értékes komponensek megóvását tekintve. Zsályakivonat esetében az ozmotikus desztilláció egy megfelelő végsürítési eljárásnak bizonyult.

Az ozmotikus desztilláció ipari méretekben való megvalósításához kapcsolódó eredményeim is biztatóak. Vizsgálatam ozmotikus ágensként olyan élelmiszer-adalékanyagokat és mütrágya alapanyagokat, melyek felhígulás után értékesíthetőek lehetnek. Az új ozmotikus oldatok tekintetében egyértelmüen pozitív képet mutat a $\mathrm{CH}_{3} \mathrm{COOK}$ oldata, már az előkísérletek során ezzek sikerült a legnagyobb integrált desztillátumfluxust elérnem $\left(2,97 \mathrm{kgm}^{-2} \mathrm{~h}^{-1}\right)$. Ez egy élelmiszeripari adalékanyag, így felhasználása nem jelent gondot az iparban, az emberi szervezetre ártalmatlan. Viszont ahhoz, hogy 
egy ozmotikus desztillációs rendszer jól tudjon müködni elengedhetetlen, hogy mélyebb ismereteket szerezzünk az anyagátadási jelenségekről, melyek a művelet során lezajlanak.

Teljes faktoros analízissal bizonyítottam, hogy a vizsgált tartományon belül a hőmérsékletkülönbségnek a betáplálás és ozmotikus oldal között nincs szignifikáns hatása a desztillátumfluxursa, míg az ozmotiks oldat telítettési állapotának, és a betáplálási hőmérsékletnek van szignifikáns hatása. Munkámmal bizonyítottam, hogy ez az oldat magasabb telítettségi tartományban sokkal hatásosabb a megszokott $\mathrm{CaCl}_{2}$-hoz képest, ami az elérhető alacsonyabb gőznyomás értékeknek köszönhető, hatékonyabb meggysürítést sikerült kiviteleznek ezzel az oldattal.

Többlépcsős MF-RO-OD meggysürítésre való felhasználását bizonyítottam, hogy ezzel a müveleti kapcsolással megvalósítható a préselt meggylé sürítése, a használt mikroszürés sikeresen csírátlanította a meggylevet, majd pedig az RO-OD kapcsolás alkalmas volt a meggylé magas $\left(\sim 60^{\circ}\right.$ Brix $)$ koncentráció tartományba való sürítésére. A mikroszürést és az fordított ozmózis két módszerét tekintve, összes antioxodáns kapacitásban nem okozott szignifikáns csökkenést, míg az összes polifenol tartalomban igen. Az ozmotikus desztilláció müveletei a különböző ozmotikus oldatokkal minden esetben szignifikáns csökkenést eredményeztek. Ezek közül viszont a legkisebb csökkenés a $\mathrm{CH}_{3} \mathrm{COOK}$ esetén volt észrevehető, mely a rövidebb müveleti idővel van összefüggésban. Ezáltal megállapítottam, hogy a müveleti körülmények által az értékes komponensek oxidatív stresszt szenvednek el, így a levegő oxigénjétől való teljes elszigetelés, a rendszer teljes fénytől való elfedése, és a lehető legrövidebb müveleti idó fontos kritériumok a magas értékesanyag tartalmú sürítmények előállítása szempontjából 


\section{CONCLUSIONS}

In the near future membrane distillation and osmotic distillation are going to be cited as an economically process. Recently, some turnkey membrane dsitillation systems are already available however, osmotic distillation is working on only in the scientific laboratories. My thesis has attempted to demonstrate how these techniques can be further insified and implemented in the industry.

My thesis focuses on two main topic: identification of LEP value and the regeneration of the wetted membranes and based on these, treatment of oil-in-water emulsion to produce clear high purity water. Another main topic is to insify osmotic distillation process applying new osmotic solution which later can be sell as product withouth supplement regeneration process. Finally, coupled membrane processes containing microfiltration (MF), reverse osmosis (RO) and osmotic distillation has been applied to concentrate sage extract and sour cherry juice.

Regarding membrane distillation, a new approach has been developed to determine one of the critical parameter in MD processes, so-called liquid entry pressure (LEP). This approach possesses advantages compared to the classical, ,static" method, because it is imitating a real process run. From this point of view operators can be extract informations which can be more crucial regarding distillate quality and process efficiency as well. Based on these results separation of an oil-in-water emulsion is practically feasible, however, a critical concentration of the dispersed oil exists. This limit can be only overcome with new-type of membranes which have to be developed in the near future. These membranes still under construction, but in small-scale application have already been acheived.

Concentrating sage extract can be overcome using coupled process. MF-RO-OD coupled process is suggested in my thesis which can use for effective cocnetration of the extract. However, siginficant valuable compond loss is occured along with the RO process. In case of osmotic distilltaion negligible valuable comőound loss is determined.

Emplying osmotic distillation with $\mathrm{CH}_{3} \mathrm{COOK}$ solution is a promising option. This salt is very soluble, thus, a solution with very low vapor pressure can be reachable, it can be perfectly use for effective osmotic distillation processes. Furthermore, this compound is a well-known food additive, thus non-toxic, it can be apply in liquid food concentration tasks. The results have presented that using $\mathrm{CH}_{3} \mathrm{COOK}$ is more effective than the classical $\mathrm{CaCl}_{2}$, however, the juice suffers valuable compound loss along the process. This can origin from the ambient physical effect such as oxidantion with 
oxygene in the air, or photochemical effect, or even temperature. To find the right answer more experiments are required. 


\section{MEGJELENT KÖZLEMÉNYEK}

\section{Szakcikk nemzetközi, impakt faktorral rendelkezö folvóiratban:}

Rácz G, Kerker S, Schmitz O, Schnabel B, Kovács Z, Vatai Gy, Ebrahimi M, Czermak P, Experimental determination of liquid entry pressure (LEP) in vacuum membrane distillation for oily wastewaters, Membrane water treatment, 2015, $\underline{\mathbf{I F}=\mathbf{0 , 4 3 6}(\mathbf{2 0 1 3})}$ (elfogadva közlésre)

Rácz G, Kerker S, Kovács Z, Vatai Gy, Ebrahimi M, Czermak P, Theoretical and experimental approaches of liquid entry pressure determination in membrane distillation processes, Polytechnica perioidica, Vol 58, No 2 (2014), pp. 81-91, DOI: 10.3311/PPch.2179 $\underline{\mathbf{I F = \mathbf { 0 , 1 3 0 }} \text { (2013) }}$

Rácz G, Alam M.R., Arekatte Ch. K, Albert K, Papp N, Stefanovits-Bányai É, Russo P, Di Matteo M, Vatai Gy, Potassium acetate solution as a promising option to osmotic distillation for sour cherry juice (Prunis Cerasus L) concentration (2014) Acta alimentaria Volume 43, Supplement 1, P: 114-123 DOI 10.1556/AAlim.43.2014.Suppl.17 $\underline{\mathbf{I F}=\mathbf{0 , 4 2 7} \text { (2013) }}$

Torun M, Rácz G, Fogarassy E, Vatai Gy, Dinçer C, Topuz A, Özdemir F, Concentration of Sage (Salvia fruticosa Miller) extract by using integrated membrane process, Separation and Purification Technology, (2014); 132:244-251. DOI: 10.1016/j.seppur.2014.05.039 $\underline{\mathbf{I F}=\mathbf{3 , 0 6 5} \text { (2013) }}$

\section{Szakcikk hazai folvóiratban:}

Rácz G, Kozák Á, Mủveleti paraméterek hatásának kísérleti vizsgálata modell oldatok ozmotikus desztillációja esetén, Membrántechnika, 2009, ISSN 2061-6392. Nyilv. szám: 76.206/1997, p.: 41-54.

\section{Szakcikk nemzetközi folyóiratban:}

Rácz G, Papp N, Hegedüs A, Szabó Z, Nyéki J, Szabó T, Stefanovits-Bányai É, Vatai Gy, Concentration of 'Oblachinska' sour cherry juice using osmotic distillation, International Journal of Horticultural Science 2012, 18 (1): 31-34. 


\section{Hazai konferencia összefoglaló:}

Rácz G, Papp N, Értékes anyagokban dús meggysürítmény elóállítása ozmotikus desztillációval, 2011. Keszthely XVII. Ifjúsági Tudományos Fórum, ISBN 987-963-9639-42-3

Rácz G, Fogarassy E, Vatai Gy, Torun M, Sahin H, Özdemir F, Zsályakivonat koncentrálása többlépcsős membrántechnikai eljárással. Müszaki Kémiai Napok, Veszprém 2011, ISBN 978-6155044-07-6, p.:189.

Rácz G, Kozák Á, Műveleti paraméterek hatása a membrán és ozmotikus desztilláció folyamatára, MTA-AMB Kutatási és Fejlesztési Tanácskozás, 2010, Gödöllö ISBN 978-963-269-165-7, p.:22.

\section{Nemzetközi konferencia összefoglaló:}

Rácz G, S. Kerker, Z. Kovács, M. Ebrahimi, P. Czermak: The Perpectives of membrane distillation in produced water treatment. Müszaki Kémiai Napok 2013, Veszprém, ISBN 978-615-5044-79-3, p.:119.

Galkó Á, Rácz G, Galambos I, Vatai Gy, Microfiltration intensification (0.1 um) using static mixer and aeration in case of whey filtration, Élelmiszertudományi Konferencia 2013, 2013, Budapest, ISBN 978963-503-550-2, p.:121-124.

Rácz G, Papp N, Vatai Gy, Concentration of sour cherry juice, XXVIII Membrane Summer School EMS, 2011, Smardzewice, Poland, ISBN 978-83-7789-027-1, p.:63.

Rácz G, Fogarassy E, Vatai Gy, Torum M, Dincer C, Sahin H, Özdemir F, Effects of the concentration treatments on sage (Salvia fruticosa) extract, 1st International Congress on Food Technology, 2010, Antalya, Turkey ISBN: 978-975-00373-3-7 p.:486, p.:189.

Rácz G, Fogarassy E, Vatai Gy, Torun M, Sahin H, Özdemir F, Concetration of Sage (Salvia Fruticosa) extract by using multistep membrane separation processes. Permea 2010, 2010, Tatranksé Matliare, Slovakia, ISBN: 978-80-227-3339-7, p.:129. 


\section{Nemzetközi konferencia teljes anyag:}

Rácz G, Kerker S, Hild J, Schmitz O, Schnabel B, Kovács Z, Vatai Gy, Ebrahimi M, Czermak P, Promising vacuum membrane distillation treatment for oil-in-water emusion as model produced water purification, Élelmiszertudományi Konferencia 2013, 2013, Budapest, ISBN 978-963-503-550-2, p.:137-140.

Rácz G, Md Rizvi Alam, Albert K, Papp N, Koris A, Di Matteo M, Vatai Gy, Estimation of overall mass transfer coefficient in osmotic distillation for gentle sour cherry juice concentration, Élelmiszertudományi Konferencia 2013, Budapest, ISBN 978-963-503-550-2, p.: 93-96.

Rácz G, Papp N, Hegedűs A, Bányai É, Vatai Gy, Concentration of Sour Cherry Juice Using Osmotic Distillation, Chinese-European cooperation for a long-term sustainability, 2011, Budapest, Corvinus University of Budapest 


\section{MELLÉKLETEK}

\section{M.I. Irodalomjegyzék}

AGUiAR, I. B., MIRANDA, N. G. M., GOMES, F. S., SANTOS, M. C. S., FREITAS, D. D. G. C., TONON, R. V. \& CABRAL, L. M. C. 2012. Physicochemical and sensory properties of apple juice concentrated by reverse osmosis and osmotic evaporation. Innovative Food Science \& Emerging Technologies, 16, 137-142.

ALKLAIBI, A. M. \& LIOR, N. 2005. Membrane-distillation desalination: Status and potential. Desalination, 171, 111-131.

Álvarez, S., RIERA, F. A., ÁlvareZ, R., COCA, J., CUPERUS, F. P., TH BOUWER, S., BOSWINKEL, G., VAN GEMERT, R. W., VELDSINK, J. W., GIORNO, L., DONATO, L., TODISCO, S., DRIOLI, E., OLSSON, J., TRÄGÅRDH, G., GAETA, S. N. \& PANYOR, L. 2000. A new integrated membrane process for producing clarified apple juice and apple juice aroma concentrate. Journal of Food Engineering, 46, 109-125.

BANAT F.A., J. S. 1994. Theoretical and experimental study in membrane distillation. Desalination, 95, 39-52.

BANAT F.A., J. S. 1995. Removal of benzene traces from contaminated water by vacuum membrane distillation. Chemical Engineering Science, 51, 1257-1265,.

BANAT F.A., J. S. 1999. Membrane distillation for dilute ethanol separation from aqueous streams. J. Membr. Sci. , 163, 333-348.

BANDINI S., A. S., G.C. SARTI 1997. Vacuum membrane distillation: experiments and modeling. AIChE J., 43, 398-408.

BANDINI S., C. G., G.C. SARTI 1992. Separation efficiency in vacuum membrane distillation. J. Membr. Sci., 73, 217-229.

BÉLAFI-BAKÓ, K. \& KOROKNAI, B. 2006. Enhanced water flux in fruit juice concentration: Coupled operation of osmotic evaporation and membrane distillation. Journal of Membrane Science, 269, 187-193.

BENZIE, I. F. F. \& STRAIN, J. J. 1996. The Ferric Reducing Ability of Plasma (FRAP) as a Measure of "Antioxidant Power": The FRAP Assay. Analytical Biochemistry, 239, 70-76. 
BLOIS, M. S. 1958. Antioxidant Determinations by the Use of a Stable Free Radical. Nature, 181, 1199-1200.

BODELL, B. R. 1963. Silicone rubber vapor diffusion in saline water distillation.

BOI, C., BANDINI, S. \& SARTI, G. C. 2005. Pollutants removal from wastewaters through membrane distillation. Desalination, 183, 383-394.

CASSANO, A., DRIOLI, E., GAlAVERNA, G., MARCHELli, R., DI SilveSTRO, G. \& CAGNASSO, P. 2003. Clarification and concentration of citrus and carrot juices by integrated membrane processes. Journal of Food Engineering, 57, 153-163.

CASSANO, A., JIAO, B. \& DRIOLI, E. 2004. Production of concentrated kiwifruit juice by integrated membrane process. Food Research International, 37, 139-148.

CASSANO, A., FIGOLI, A., TAGARELli, A., SINDONA, G. \& DRIOLI, E. 2006. Integrated membrane process for the production of highly nutritional kiwifruit juice. Desalination, 189, 21-30.

CELERE, M. \& GOSTOLI, C. 2004. Osmotic distillation with propylene glycol, glycerol and glycerolsalt mixtures. Journal of Membrane Science, 229, 159-170.

CELERE, M. \& GOSTOLI, C. 2005. Heat and mass transfer in osmotic distillation with brines, glycerol and glycerol-salt mixtures. Journal of Membrane Science, 257, 99-110.

CHANG, C. C., YANG, M. H., WEN, H. M. \& CHERN, J. C. 2002. Estimation of total flavonoid content in propolis by two complementary colometric methods. Journal of Food and Drug Analysis, 10, 178-182.

CHIAM, C.-K. \& SARBATLY, R. 2013. Vacuum membrane distillation processes for aqueous solution treatment-A review. Chemical Engineering and Processing: Process Intensification, 74, 2754.

COUFFIN N., C. C., V. LAHOUSSINE-TURCAUD 1998 A new process to remove halogenated VOCs for drinking water production vacuum membrane distillation. Desalination, 117, 233-245.

CRISCUOli, A., ZHONG, J., FIGOli, A., CARNEVAlE, M. C., HUANG, R. \& DRIOLI, E. 2008. Treatment of dye solutions by vacuum membrane distillation. Water Res, 42, 5031-7. 
CRISCUOLI, A., BAFARO, P. \& DRIOLI, E. 2012. Vacuum membrane distillation for purifying waters containing arsenic. Desalination.

CSÉFALVAY E., D. A., FARKAS TIVADAR, HANÁK LÁSZLÓ, MIKA LÁSZLÓ TAMÁS, MIZSEY PÉTER, SAWINSKY JÁNOS, SIMÁNDI BÉLA, SZÁNYA TIBOR, SZÉKEKY EDIT, VÁGÓ EMESE 2011. Vegyipari müveletek II. Anyagátadó müveletek és kémiai reaktorok, Budapest, Typotex Kiadó.

Delamare L., A. P., MOSCHEN-PISTOREllo, I. T., ARTICO, L., ATTI-SERAFINI, L. \& ECHEVERRIGARAY, S. 2007. Antibacterial activity of the essential oils of Salvia officinalis L. and Salvia triloba L. cultivated in South Brazil. Food Chemistry, 100, 603-608.

DINCER, C., TOPUZ, A., SAHIN-NADEEM, H., OZDEMIR, K. S., CAM, I. B., TONTUL, I., GOKTURK, R. S. \& AY, S. T. 2012. A comparative study on phenolic composition, antioxidant activity and essential oil content of wild and cultivated sage (Salvia fruticosa Miller) as influenced by storage. Industrial Crops and Products, 39, 170-176.

DING, Z., LIU, L., LI, Z., MA, R. \& YANG, Z. 2006. Experimental study of ammonia removal from water by membrane distillation (MD): The comparison of three configurations. Journal of Membrane Science, 286, 93-103.

DING, Z., LIU, L., YU, J., MA, R. \& YANG, Z. 2008. Concentrating the extract of traditional Chinese medicine by direct contact membrane distillation. Journal of Membrane Science, 310, 539-549.

DRIOLI E., Y. W., V. CALABRO 1987. Membrane distillation in the treatment of aqueous solutions. J. Membr. Sci. , 33, 277-284.

EL AMALI A., S. B., M. MAALEJ 2004. Experimental study of air gap and direct contact membrane distillation configurations: application to geothermal and seawater desalination. Desalination, 168 (2004), 357.

EL-SAYED, N. H., EL-ERAKY, W., IBRAHIM, M. T. \& MABRY, T. J. 2006. Antiinflammatory and ulcerogenic activities of Salvia triloba extracts. Fitoterapia, 77, 333-5.

FINDLEY, M. E. 1967. Vaporization through porous membranes. Ind. Eng. Chem. Process Des. Dev., $6,226-37$. 
FRANKEN A.C.M., J. A. M. N., M.H.V. MULDER, D. BARGEMAN AND C, A. SMOLDERS 1987. Wetting criteria for the applicability of membrane distillation. Journal of Membrane Science, 33, 315328.

GAlAVERNA, G., DI SIlVESTRO, G., CASSANO, A., SFORZA, S., DOSSENA, A., DRIOLI, E. \& MARCHELLI, R. 2008. A new integrated membrane process for the production of concentrated blood orange juice: Effect on bioactive compounds and antioxidant activity. Food Chemistry, 106, 10211030.

GÁLVEZ JULIÁN BLANCO, L. G.-R., ISABEL MARTÍN-MATEOS 2009. Seawater desalination by an innovative solar-powered membrane distillation system: the MEDESOL project. Desalination, 246, $567-576$.

GARCÍA-PAYO M.C., M. A. I.-G., C. FERNÁNDEZ-PINEDA 2000a. Air gap membrane distillation of aqueous alcohol solutions. Journal of Membrane Science, 169 61-80.

GARCIA-PAYO, M. C., IZQUIERDO-GIL, M. A. \& FERNANDEZ-PINEDA, C. 2000b. Wetting Study of Hydrophobic Membranes via Liquid Entry Pressure Measurements with Aqueous Alcohol Solutions. J Colloid Interface Sci, 230, 420-431.

GARCÍA-PAYO M.C., C. A. R., I.W. MARISON, U. VON STOCKAR 2002. Separation of binary mixtures by thermostatic sweeping gas membrane distillation II. Experimental results with aqueous formic acid solutions. Journal of Membrane Science, 198 (2002) 197-210.

GETHARD, K. \& MITRA, S. 2011. Membrane distillation as an online concentration technique: application to the determination of pharmaceutical residues in natural waters. Anal Bioanal Chem, 400, $571-5$.

GRYTA M., K. K. 1999. The application of membrane distillation for the concentration of oil-water emulsions. Desalination, 121 (1999), 23-29.

GRYTA M. KARAKULSKI K., A. W. M. 2001. Purification of wastewater by hybrid UF/MD. Wat. Res., 35, 3665-3669.

GRYTA, M. 2001. The fermentation process integrated with membrane distillation. Separation and Purification Technology, 24 (2001), 283-296. 
GRYTA, M. 2002. The assessment of microorganism growth in the membrane distillation system. Desalination, 142 (2002), 79-88.

GRYTA, M. 2008a. Alkaline scaling in the membrane distillation process. Desalination, 228, 128-134.

GRYTA, M. 2008b. Fouling in direct contact membrane distillation process. Journal of Membrane Science, 325, 383-394.

HANEMAAIJER, J. H. 2004. Memstill ${ }^{\circledR}$ — low cost membrane distillation technology for seawater desalination. Desalination, 168, 355.

HANEMAAIJER, J. H., VAN MEDEVOORT, J., JANSEN, A. E., DOTREMONT, C., VAN SONSBEEK, E., YUAN, T. \& DE RYCK, L. 2006. Memstill membrane distillation - a future desalination technology. Desalination, 199, 175-176.

HASANOĞLU, A., REBOllEDO, F., PlAZA, A., TORRES, A. \& ROMERO, J. 2012. Effect of the operating variables on the extraction and recovery of aroma compounds in an osmotic distillation process coupled to a vacuum membrane distillation system. Journal of Food Engineering, 111, 632641.

HE, K., HWANG, H. J. \& MOON, I. S. 2011. Air gap membrane distillation on the different types of membrane. Korean Journal of Chemical Engineering, 28, 770-777.

HEGEDÜS A., S. B. É. 2012. Természetes antioxidáns-forrásunk: a gyümölcs, Debreceni Egyetem, AGTC, Kertészettudományi Intézet.

HOGAN PAUl A., R. P. C., PAUL A. PETERSON, ROBERT A. JOHNSON, ALAN S. MICHAELS, 1998. A new option - osmotic distillation. CHEMICAL ENGINEERING PROGRESS.

HONGVAlEERAT, C., CABRAL, L. M. C., DORNIER, M., REYNES, M. \& NINGSANOND, S. 2008. Concentration of pineapple juice by osmotic evaporation. Journal of Food Engineering, 88, 548552.

IMDAKM, A. O. \& MATSUURA, T. 2005. Simulation of heat and mass transfer in direct contact membrane distillation (MD): The effect of membrane physical properties. Journal of Membrane Science, 262, 117-128. 
IZQUIERDO-GIL M.A., M. C. G.-P., C. FERNAÂNDEZ-PINEDA 1999 Air gap membrane distillation of sucrose aqueous solutions. Journal of Membrane Science, 155, 291 - 307.

JANSEN, A. E., ASSINK, J. W., HANEMAAIJER, J. H., VAN MEDEVOORT, J. \& VAN SONSBEEK, E. 2013. Development and pilot testing of full-scale membrane distillation modules for deployment of waste heat. Desalination, 323, 55-65.

JAYAPRAKASAM, B., VAREED, S. K., OLSON, L. K. \& NAIR, M. G. 2005. Insulin secretion by bioactive anthocyanins and anthocyanidins present in fruits. J Agric Food Chem, 53, 28-31.

JIAO, B., CASSANO, A. \& DRIOLI, E. 2004. Recent advances on membrane processes for the concentration of fruit juices: a review. Journal of Food Engineering, 63, 303-324.

KANG, S. Y., SEERAM, N. P., NAIR, M. G. \& BOURQUIN, L. D. 2003. Tart cherry anthocyanins inhibit tumor development in Apc(Min) mice and reduce proliferation of human colon cancer cells. Cancer Lett, 194, 13-9.

KARAKULSKI K., A. K., A.W. MORAWSKI 1995. Purification of oily wastewater by ultrafiltration. Separations Technology, 5 (1995), 197-205.

KHAYET M., T. M. 2003. Application of surface modifying macromolecules for the preparation of membranes for membrane distillation. Desalination, 158 (2003), 51-56.

KHAYET MOHAMED, T. M. 2001. Preparation and Characterization of Polyvinylidene Fluoride Membranes for Membrane Distillation. Ind. Eng. Chem. Res., 40, 5710-5718.

KHAYET M., M. P. G., J.I. MENGUAL 2004a. Study of asymmetric polarization in direct contact membrane distillation. Sep. Sci. Technol. , 39, 125-147.

KHAYET, M., VELÁZQUEZ, A. \& MENGUAL, J. I. 2004b. Modelling mass transport through a porous partition: Effect of pore size distribution. Journal of Non-Equilibrium Thermodynamics, 29.

KHAYET, M., MATSUURA, T., MENGUAL, J. I. \& QTAISHAT, M. 2006. Design of novel direct contact membrane distillation membranes. Desalination, 192, 105-111.

KHAYET, M. 2011a. Membranes and theoretical modeling of membrane distillation: a review. Adv Colloid Interface Sci, 164, 56-88.

KHAYET, M., MATSUURA, T. 2011b. Membrane distillation: Principles and Applications, Elsevier. 
KHEMAKHEM, S. \& AMAR, R. B. 2011. Modification of Tunisian clay membrane surface by silane grafting: Application for desalination with Air Gap Membrane Distillation process. Colloids and Surfaces A: Physicochemical and Engineering Aspects, 387, 79-85.

KIM J., S. E. P., T.S. KIM, D.Y. JEONG, K.H. KO 2004. Isotopic water separation using AGMD and VEMD. Nukleonika, 49, 137-142.

KOROKNAI, B., KISS, K., GUBICZA, L. \& BELAFI-BAKO, K. 2006. Coupled operation of membrane distillation and osmotic evaporation in fruit juice concentration. Desalination, 200, 526-527.

KOZÁK, Á., BÁNVÖLGYI, S., VINCZE, I., KISS, I., BÉKÁSSY-MOLNÁR, E. \& VATAI, G. 2008. Comparison of integrated large scale and laboratory scale membrane processes for the production of black currant juice concentrate. Chemical Engineering and Processing: Process Intensification, 47, 1171-1177.

KOZÁK, Á., BÉKÁSSY-MOLNÁR, E. \& VATAI, G. 2009. Production of black-currant juice concentrate by using membrane distillation. Desalination, 241, 309-314.

LAWSON KEVIN W., M. S. H., DOUGLAS R. LLOYD 1995. Compaction of microporous membranes used in membrane distillation. I. Effect on gas permeability. Journal of Membrane Science, $101(1995)$

LAWSON KEVIN W., D. R. L. 1996 Membrane distillation. I. Module design and performance evaluation using vacuum membrane distillation. Journal of Membrane Science, 121 (1996), 111-121.

LAWSON KEVIN W., D. R. L. 1997. Review: Membrane distillation. Journal of Membrane Science, 124 (1997), 125.

LEE C.H., W. H. H. 2001. Effect of operating variables on the flux and selectivity in sweep gas membrane distillation for dilute aqueous isopropanol. J. Membr. Sci. , 188 (2001), 79-86.

LEWANDOWICZ, G., BIAŁAS, W., MARCZEWSKI, B. \& SZYMANOWSKA, D. 2011. Application of membrane distillation for ethanol recovery during fuel ethanol production. Journal of Membrane Science, 375, 212-219. 
MARTINEZ-DIEZ L., M. I. V.-G. 1998. Effect of polarization on mass transport through hydrophobic porous membranes. J. Ind. Eng. Chem. Res., 37, 4128-4135.

MARTÍ1NEZ-DÍEZ L., M. I. V.-G. 1999 Temperature and concentration polarization in membrane disillation of aqueous salt solutions. Journal of Membrane Science, 156, 265-273.

MENGUAL, J. I., KHAYET, M. \& GODINO, M. P. 2004. Heat and mass transfer in vacuum membrane distillation. International Journal of Heat and Mass Transfer, 47, 865-875.

NANDI B. K., R. U. M. K. P. 2009. Treatment of Oily Waste Water Using Low-Cost Ceramic Membrane: Flux Decline Mechanism and Economic Feasibility Separation Science and Technology 44.

NENE SANJAY, S. K., K. SUMOD, BHAGYASHREE JOSHI, K.S.M.S. RAGHAVARAO 2002. Membrane distillation for the concentration of raw cane-sugar syrup and membrane clarified sugarcane juice. Desalination, 147 157-160.

NGHIEM, L. D. \& CATH, T. 2011. A scaling mitigation approach during direct contact membrane distillation. Separation and Purification Technology, 80, 315-322.

ONSEKIZOGLU, P. 2013. Production of high quality clarified pomegranate juice concentrate by membrane processes. Journal of Membrane Science, 442, 264-271.

PAL, P. \& MANNA, A. K. 2010. Removal of arsenic from contaminated groundwater by solar-driven membrane distillation using three different commercial membranes. Water Res, 44, 5750-60.

PERRY, R. H., DON W. GREEN, JAMES O. MALONEY 1984. Perry's Chemical Engineers' Handbook, New York: McGraw-Hill, .

PHATTARANAWIK J., R. J., A.G. FANE 2003. Heat transport and membrane distillation coefficients in direct contact membrane distillation. Journal of Membrane Science, 212 (2003), 177-193.

QU, D., WANG, J., HOU, D., LUAN, Z., FAN, B. \& ZHAO, C. 2009. Experimental study of arsenic removal by direct contact membrane distillation. J Hazard Mater, 163, 874-9.

RALUY, R. G., SCHWANTES, R., SUBIELA, V. J., PEÑATE, B., MELIÁN, G. \& BETANCORT, J. R. 2012. Operational experience of a solar membrane distillation demonstration plant in Pozo Izquierdo-Gran Canaria Island (Spain). Desalination, 290, 1-13. 
REKTOR, A., VATAI, G. \& BÉKÁSSY-MOLNÁR, E. 2006. Multi-step membrane processes for the concentration of grape juice. Desalination, 191, 446-453.

RIVIER C.A., M. C. G.-P., I.W. MARISON, U. VON STOCKAR 2002. Separation of binary mixtures by thermostatic sweeping gas membrane distillation I. Theory and simulations. Journal of Membrane Science 201 (2002) 1-16.

RODRIGUES, R. B., MENEZES, H. C., CABRAL, L. M. C., DORNIER, M., RIOS, G. M. \& REYNES, M. 2004. Evaluation of reverse osmosis and osmotic evaporation to concentrate camu-camu juice (Myrciaria dubia). Journal of Food Engineering, 63, 97-102.

SAKAI K., T. K., TOSHIHITO MUROI 1988. Effect of temperature polarization on water vapor permeability for blood in membrane distillation. Chem. Eng. Jpn., 38, 833.

SCHOFIELD R.W., A. G. F., C.J.D. FELL, R. MACOUN 1987. Heat and mass transfer in membrane distillation. J. Membr. Sci. , 33, 299-313.

SCHOFIELD R.W., A. G. F., C.J.D. FELL, R. MACOUN 1990a. Factors affecting flux in membrane distillation. Desalination, 77, 279-294.

SCHOFIELD R.W., A. G. F., C.J.D. FELL, R. MACOUN 1990b. Gas and vapor transport through microporous membrane. I. Knudsen-Poiseuille transition. J. Membr. Sci. , 53 159-171.

SEERAM, N. P., MOMIN, R. A., NAIR, M. G. \& BOURQUIN, L. D. 2001. Cyclooxygenase inhibitory and antioxidant cyanidin glycosides in cherries and berries. Phytomedicine, 8, 362-9.

SHIN, C. H. \& JOHNSON, R. 2007. Identification of an appropriate osmotic agent for use in osmotic distillation. Journal of Industrial and Engineering Chemistry, 13, 926-931.

SINGH V., M. K. P. C. D. 2011. Cross-Flow Microfiltration of Industrial Oily Wastewater: Experimental and Theoretical Consideration Separation Science and Technology, 46.

SINGH, D. \& SIRKAR, K. K. 2012. Desalination of brine and produced water by direct contact membrane distillation at high temperatures and pressures. Journal of Membrane Science, 389, 380-388.

SINGLETON V.L., J. A. R. 1965. Colorimetry of Total Phenolics with PhosphomolybdicPhosphotungstic Acid Reagents. Am. J. Enol. Vitic., 16, 144-158.

SMOLDER, K. F., A. D. M. 1989. Terminology for Membrane Distillation. Desalination, 72, 249. 
SUSANTO, H. 2011. Towards practical implementations of membrane distillation. Chemical Engineering and Processing: Process Intensification, 50, 139-150.

TEPE, B., SOKMEN, M., AKPUlAT, H. A. \& SOKMEN, A. 2006. Screening of the antioxidant potentials of six Salvia species from Turkey. Food Chemistry, 95, 200-204.

TOMASZEWSKA M., M. G., A.W. MORAWSKI 1995. Study on the concentration of acids by membrane distillation. Journal of Membrane Science, 102, 113-122.

TOMASZEWSKA M., M. G., A.W. MORAWSKI 1998. The influence of salt in solution on hydrochloric acid recovery by membrane distillation. Sep. Purif. Technol., 14, 183-188.

TOPCU, G. 2006. Bioactive Triterpenoids from Salvia Species. J. Nat. Prod., 69, 482-487.

TORUN, M., DINCER, C., TOPUZ, A., SAHIN-NADEEM, H. \& OZDEMIR, F. 2014. Aqueous extraction kinetics of soluble solids, phenolics and flavonoids from sage (Salvia fruticosa Miller) leaves. Journal of Food Science and Technology, 1-9.

VALDÉS, H., ROMERO, J., SAAVEDRA, A., PLAZA, A. \& BUBNOVICH, V. 2009. Concentration of noni juice by means of osmotic distillation. Journal of Membrane Science, 330, 205-213.

VINCZE, I., BÁNYAI-STEFANOVITS, É. \& VATAI, G. 2007. Concentration of sea buckthorn (Hippophae rhamnoides L.) juice with membrane separation. Separation and Purification Technology, $57,455-460$.

WANG, B.-J., WEI, T.-C. \& YU, Z.-R. 2005. Effect of operating temperature on component distribution of West Indian cherry juice in a microfiltration system. LWT - Food Science and Technology, 38, 683-689.

WINTER, D., KOSCHIKOWSKI, J. \& WIEGHAUS, M. 2011. Desalination using membrane distillation: Experimental studies on full scale spiral wound modules. Journal of Membrane Science, $375,104-112$.

XIE, Z., DUONG, T., HOANG, M., NGUYEN, C. \& BOLTO, B. 2009. Ammonia removal by sweep gas membrane distillation. Water Res, 43, 1693-9. 
YARLAGADDA, S., GUDE, V. G., CAMACHO, L. M., PINAPPU, S. \& DENG, S. 2011. Potable water recovery from As, U, and F contaminated ground waters by direct contact membrane distillation process. J Hazard Mater, 192, 1388-94.

ZAKRZEWSKA-TRZNADEL G. M. H., A.G. CHMIELEWSKI 1999 Concentration of radioactive components in liquid low-level radioactive. Journal of Membrane Science (1999) 163, 257-264.

ZHAO, Z.-P., MA, F.-W., LIU, W.-F. \& LIU, D.-Z. 2008. Concentration of ginseng extracts aqueous solution by vacuum membrane distillation. 1. Effects of operating conditions. Desalination, 234, 152157.

ZHAO, Z.-P. , ZHU, C.-Y., LIU, D.-Z. \& LIU, W.-F. 2011. Concentration of ginseng extracts aqueous solution by vacuum membrane distillation 2. Theory analysis of critical operating conditions and experimental confirmation. Desalination, 267, 147-153. 


\section{M.II. A membránpórus-nedvesedés jelelensége}

\begin{tabular}{|c|c|c|c|c|c|c|}
\hline Gyártó & Membrán & Polimer & Modul & $\mathbf{d}_{\mathrm{p}}, \boldsymbol{\mu m}$ & LEP $_{w}$, bar & Hivatkozás \\
\hline $\begin{array}{l}\text { Pall Gelman } \\
\text { (Port Washington, } \\
\text { NY, USA) }\end{array}$ & TF200 & $\mathrm{PTFE} / \mathrm{PP}^{\mathrm{a}}$ & $\begin{array}{l}\text { Kompozit } \\
\text { lapmembrán }\end{array}$ & 0,20 & $2,82 / 2,76 \pm 0,09$ & $\begin{array}{l}\text { Membrane data sheet by Pall } \\
\text { Gelman/ Measured value } \\
\text { (Khayet et al., 2004) }\end{array}$ \\
\hline $\begin{array}{c}\text { Pall Gelman (Port } \\
\text { Washington, NY, } \\
\text { USA) }\end{array}$ & TF450 & $\mathrm{PTFE} / \mathrm{PP}^{\mathrm{a}}$ & $\begin{array}{l}\text { Kompozit } \\
\text { lapmembrán }\end{array}$ & 0,45 & 1,38 & $\begin{array}{c}\text { Membrane data sheet by Pall } \\
\text { Gelman }\end{array}$ \\
\hline $\begin{array}{c}\text { Pall Gelman (Port } \\
\text { Washington, NY, } \\
\text { USA) }\end{array}$ & TF1000 & $\mathrm{PTFE} / \mathrm{PP}^{\mathrm{a}}$ & $\begin{array}{l}\text { Supported } \\
\text { lapmembrán }\end{array}$ & 1,00 & 0,48 & $\begin{array}{c}\text { Membrane data sheet by Pall } \\
\text { Gelman }\end{array}$ \\
\hline $\begin{array}{c}\text { Gore Inc. } \\
\text { (Newark, USA) }\end{array}$ & Gore (PT20) & PTFE & lapmembrán & 0,2 & $3,68 \pm 0,01$ & $\begin{array}{l}\text { Measured value (M.A. } \\
\text { Izquierdo-Gil, } 1999 \text { ) }\end{array}$ \\
\hline $\begin{array}{c}\text { Gore Inc. } \\
\text { (Newark, USA) }\end{array}$ & Gore (PT45) & PTFE & lapmembrán & 0,45 & $2,88 \pm 0,01$ & $\begin{array}{l}\text { Measured value (M.A. } \\
\text { Izquierdo-Gil, 1999) }\end{array}$ \\
\hline $\begin{array}{c}\text { Gore Inc. } \\
\text { (Newark, USA) }\end{array}$ & Gore (PTS20) & $\mathrm{PTFE} / \mathrm{PP}^{\mathrm{a}}$ & $\begin{array}{l}\text { Kompozit } \\
\text { lapmembrán }\end{array}$ & 0,2 & 4,63 & $\begin{array}{l}\text { Measured value (M.A. } \\
\text { Izquierdo-Gil, 1999) }\end{array}$ \\
\hline $\begin{array}{l}\text { Microdyn- Nadir } \\
\text { GmbH (Wiesbaden, } \\
\text { Germany) }\end{array}$ & MD020CP2N & PP & $\begin{array}{l}\text { Csöves } \\
\text { membrán modul }\end{array}$ & 0,2 & 1,40 & $\begin{array}{c}\text { Membrane data sheet by } \\
\text { Microdyn-Nadir (Mengual et } \\
\text { al., 2004) }\end{array}$ \\
\hline $\begin{array}{l}\text { Merck Millipore Inc. } \\
\text { (Billerica, USA) }\end{array}$ & GVHP/Durapore & PVDF & lapmembrán & 0,22 & $2,04 / 2,29 \pm 0,03$ & $\begin{array}{c}\text { Membrane data sheet by } \\
\text { Merck Millipore/ Measured } \\
\text { value (M.A. Izquierdo-Gil, } \\
1999 \text { ) }\end{array}$ \\
\hline $\begin{array}{l}\text { Merck Millipore Inc. } \\
\text { (Billerica, USA) }\end{array}$ & HVHP/Durapore & PVDF & lapmembrán & 0,45 & $\begin{array}{l}1,05 / 1,10 \pm \\
0,04\end{array}$ & $\begin{array}{l}\text { Membrane data sheet by } \\
\text { Merck Millipore/ (M.A. } \\
\text { Izquierdo-Gil, 1999) }\end{array}$ \\
\hline $\begin{array}{l}\text { Merck Millipore Inc. } \\
\text { (Billerica, USA) }\end{array}$ & FGLP & $\mathrm{PTFE} / \mathrm{PE}^{\mathrm{a}}$ & $\begin{array}{c}\text { Kompozit } \\
\text { lapmembrán }\end{array}$ & 0,20 & 2,80 & $\begin{array}{l}\text { Membrane data sheet by } \\
\text { Merck Millipore }\end{array}$ \\
\hline $\begin{array}{l}\text { Merck Millipore Inc. } \\
\text { (Billerica, USA) }\end{array}$ & FHLP & $\mathrm{PTFE} / \mathrm{PE}^{\mathrm{a}}$ & $\begin{array}{c}\text { Kompozit } \\
\text { lapmembrán }\end{array}$ & 0,50 & 1,24 & $\begin{array}{l}\text { Membrane data sheet by } \\
\text { Merck Millipore }\end{array}$ \\
\hline
\end{tabular}


M.III. Vákuumos regenerálási eljárás folyamatábrája.

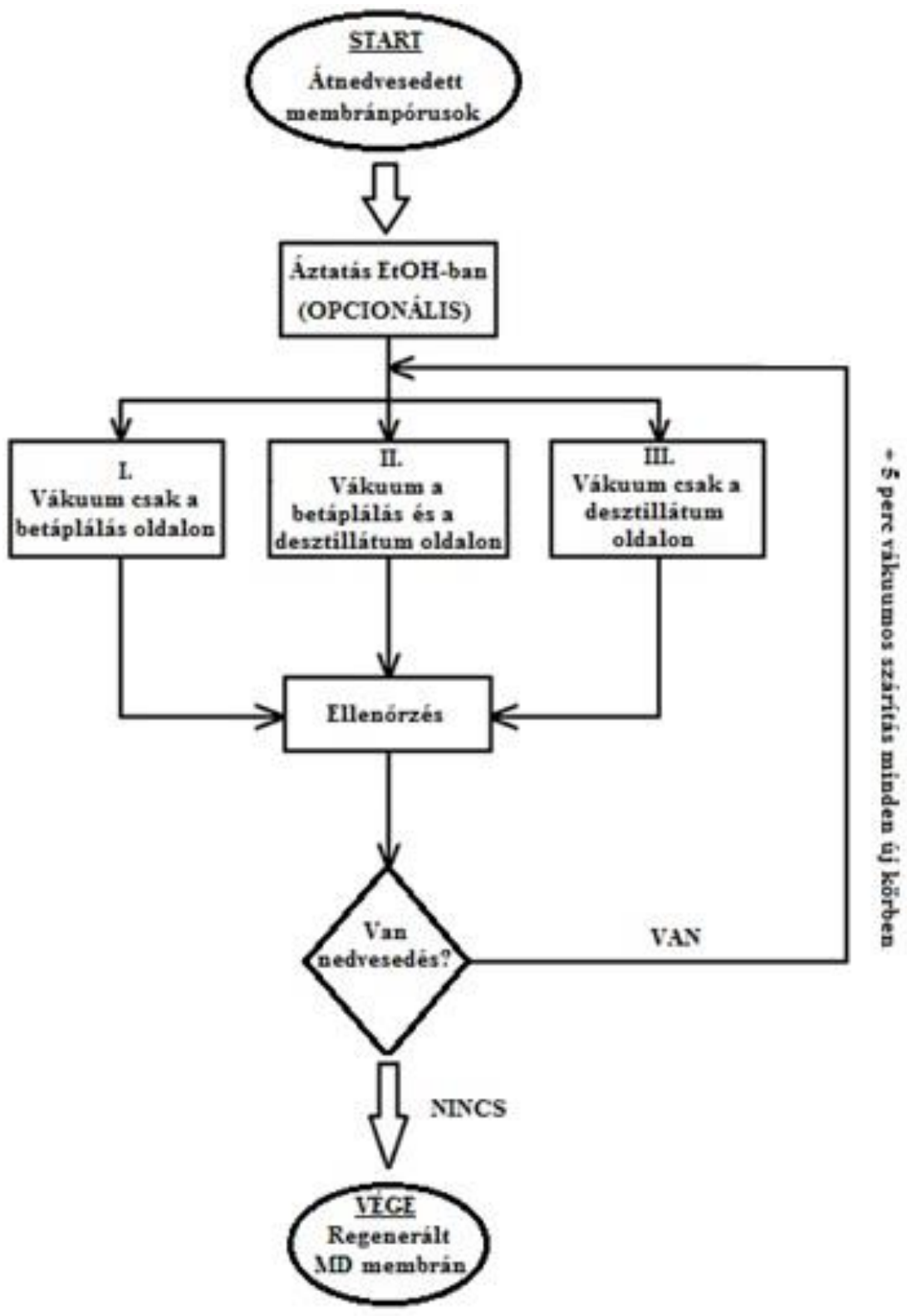




\section{M.IV. Kísérlettervhez integrált desztillátumfluxus értékei}

\begin{tabular}{|c|c|c|c|c|}
\hline Mérési szám & $\Delta \mathbf{T}\left({ }^{\circ} \mathbf{C}\right)$ & $\mathbf{C}_{\text {sóoldat }(\%)}$ & $\mathbf{T}_{\text {betáp }}\left({ }^{\circ} \mathbf{C}\right)$ & $\begin{array}{c}\text { Integrált desztillátum fluxus } \\
\mathbf{k g m}^{-2} \mathbf{h}^{-\mathbf{1}}\end{array}$ \\
\hline $\mathbf{1 .}$ & + & + & + & 1,93 \\
\hline $\mathbf{2 .}$ & + & + & - & 1,18 \\
\hline $\mathbf{3 .}$ & + & - & - & 0,26 \\
\hline $\mathbf{4 .}$ & - & + & + & 1,65 \\
\hline $\mathbf{5 .}$ & - & - & + & 0,33 \\
\hline $\mathbf{6 .}$ & - & + & - & 0,46 \\
\hline $\mathbf{7 .}$ & + & - & + & 0,22 \\
\hline $\mathbf{8 .}$ & - & - & - & 0,80 \\
\hline $\mathbf{9 .}$ & 0 & 0 & 0 & 0,81 \\
\hline $\mathbf{1 0 .}$ & 0 & 0 & 0 & 0,83 \\
\hline $\mathbf{1 1 .}$ & 0 & 0 & 0 & \\
\hline
\end{tabular}




\section{M.V. Kísérlettervhez kapcsolódó statisztikai táblák és ábrák}

\begin{tabular}{|c|c|c|c|c|c|c|c|c|c|c|}
\hline \multirow[b]{2}{*}{ Factor } & \multicolumn{10}{|c|}{$\begin{array}{l}\text { Effect Estimates; Var :DV_1; R-sqr=,99233; Adj:,97443 (Design: } 2^{* *}(3-0) \text { design (Spreadsheet11) in nagyonjó.stw } \\
2^{\star *}(3-0) \text { design; MS Residual=,0084159 } \\
\text { DV: DV_1 }\end{array}$} \\
\hline & Effect & Std.Err. & $t(3)$ & $p$ & $\begin{array}{c}-95, \% \\
\text { Cnf.Limt }\end{array}$ & $\begin{array}{r}+95, \% \\
\text { Cnf.Limt }\end{array}$ & Coeff. & $\begin{array}{c}\text { Std.Err. } \\
\text { Coeff. }\end{array}$ & $\begin{array}{c}-95, \% \\
\text { Cnf.Limt }\end{array}$ & $\begin{array}{r}+95, \% \\
\text { Cnf.Limt }\end{array}$ \\
\hline Mean/Interc. & 0,890818 & 0,027660 & 32,20581 & 0,000066 & 0,802791 & 0,978846 & 0,890818 & 0,027660 & 0,802791 & 0,978846 \\
\hline (1)Sat(\%) & 1,203725 & 0,064869 & 18,55628 & 0,000342 & 0,997283 & 1,410167 & 0,601863 & 0,032434 & 0,498642 & 0,705083 \\
\hline$(2) \mathrm{T}\left({ }^{\circ} \mathrm{C}\right)$ & 0,340775 & 0,064869 & 5,25329 & 0,013435 & 0,134333 & 0,547217 & 0,170387 & 0,032434 & 0,067167 & 0,273608 \\
\hline (3)deltaT $\left({ }^{\circ} \mathrm{C}\right)$ & 0,073475 & 0,064869 & 1,13267 & 0,339695 & $-0,132967$ & 0,279917 & 0,036737 & 0,032434 & $-0,066483$ & 0,139958 \\
\hline 1 by 2 & 0,190175 & 0,064869 & 2,93168 & 0,060918 & $-0,016267$ & 0,396617 & 0,095087 & 0,032434 & $-0,008133$ & 0,198308 \\
\hline 1 by 3 & $-0,011825$ & 0,064869 & $-0,18229$ & 0,866977 & $-0,218267$ & 0,194617 & $-0,005913$ & 0,032434 & $-0,109133$ & 0,097308 \\
\hline 2 by 3 & 0,135325 & 0,064869 & 2,08613 & 0,128249 & $-0,071117$ & 0,341767 & 0,067662 & 0,032434 & $-0,035558$ & 0,170883 \\
\hline $1 * 2 * 3$ & 0,087325 & 0,064869 & 1,34618 & 0,270929 & $-0,119117$ & 0,293767 & 0,043663 & 0,032434 & $-0,059558$ & 0,146883 \\
\hline
\end{tabular}

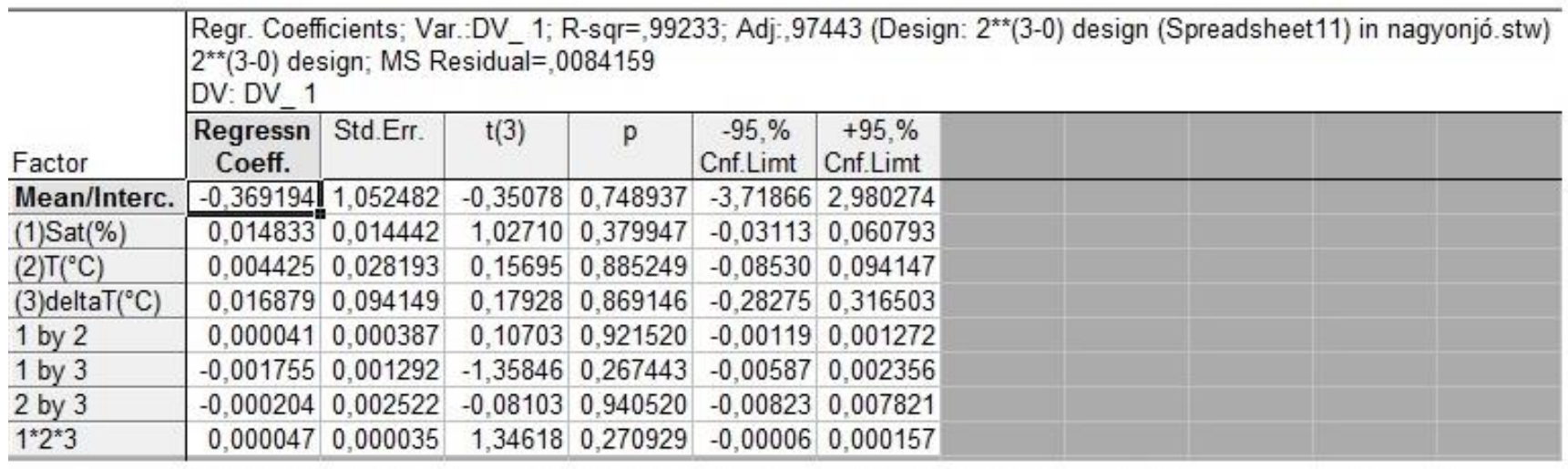

ANOVA; Var.:DV_ 1; R-sqr=,99233; Adj:,97443 (Design: 2**(3-0) design (Spreadsheet11) in nagyonjó.stw) $2^{* *}(3-0)$ design; $\overline{M S}$ Residual $=, 0084159$

DV: DV_ 1

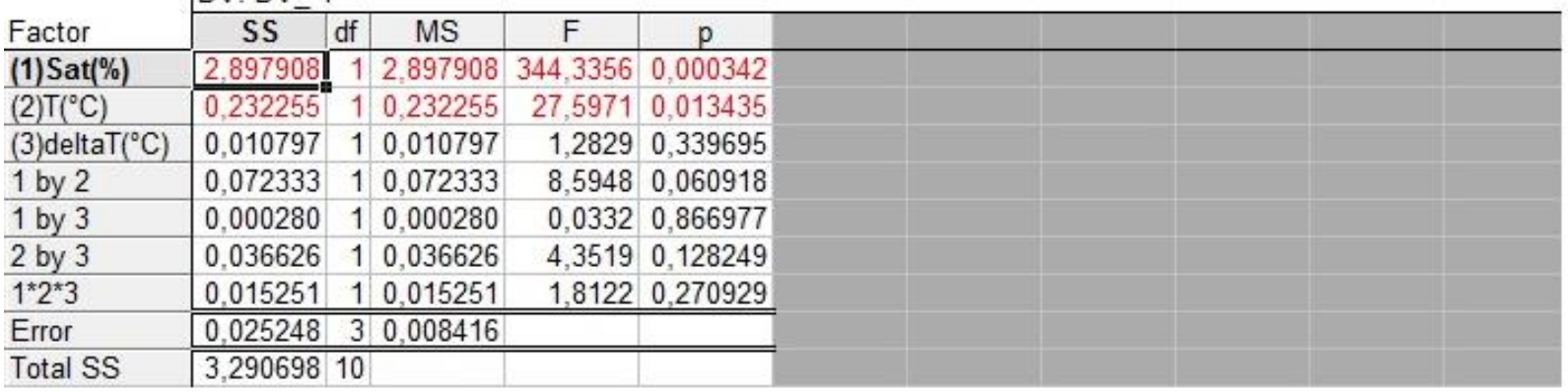


M.VI. Kísérlettervhez kapcsolódó statisztikai táblák és ábrák
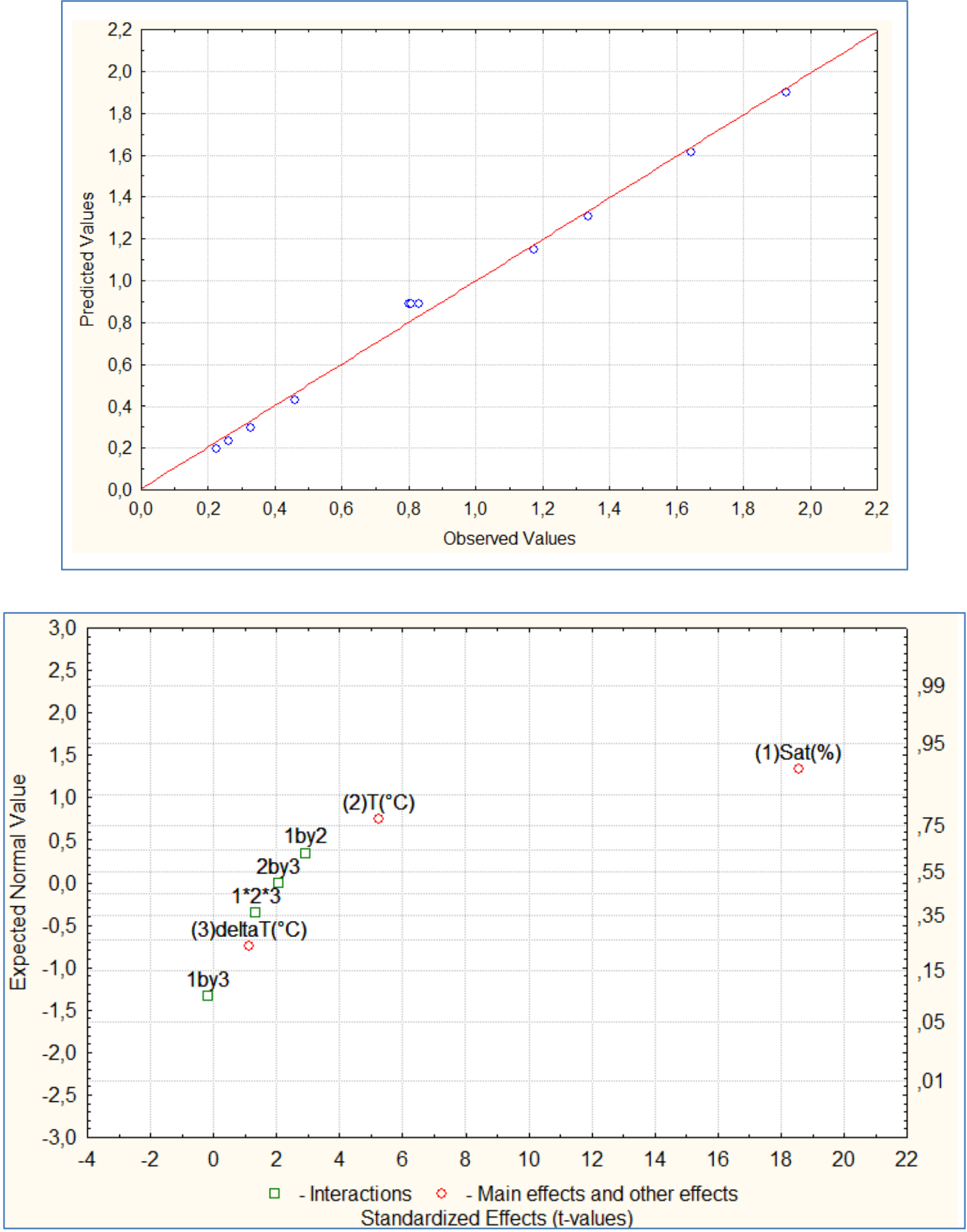
M.VII. Meggylé, $\mathrm{CH}_{3} \mathrm{COOK}$ és $\mathrm{CaCl}_{2}$ látszólagos viszkozitása az összetétel függvénylében $\left(3^{\circ} \mathrm{C}\right)$.

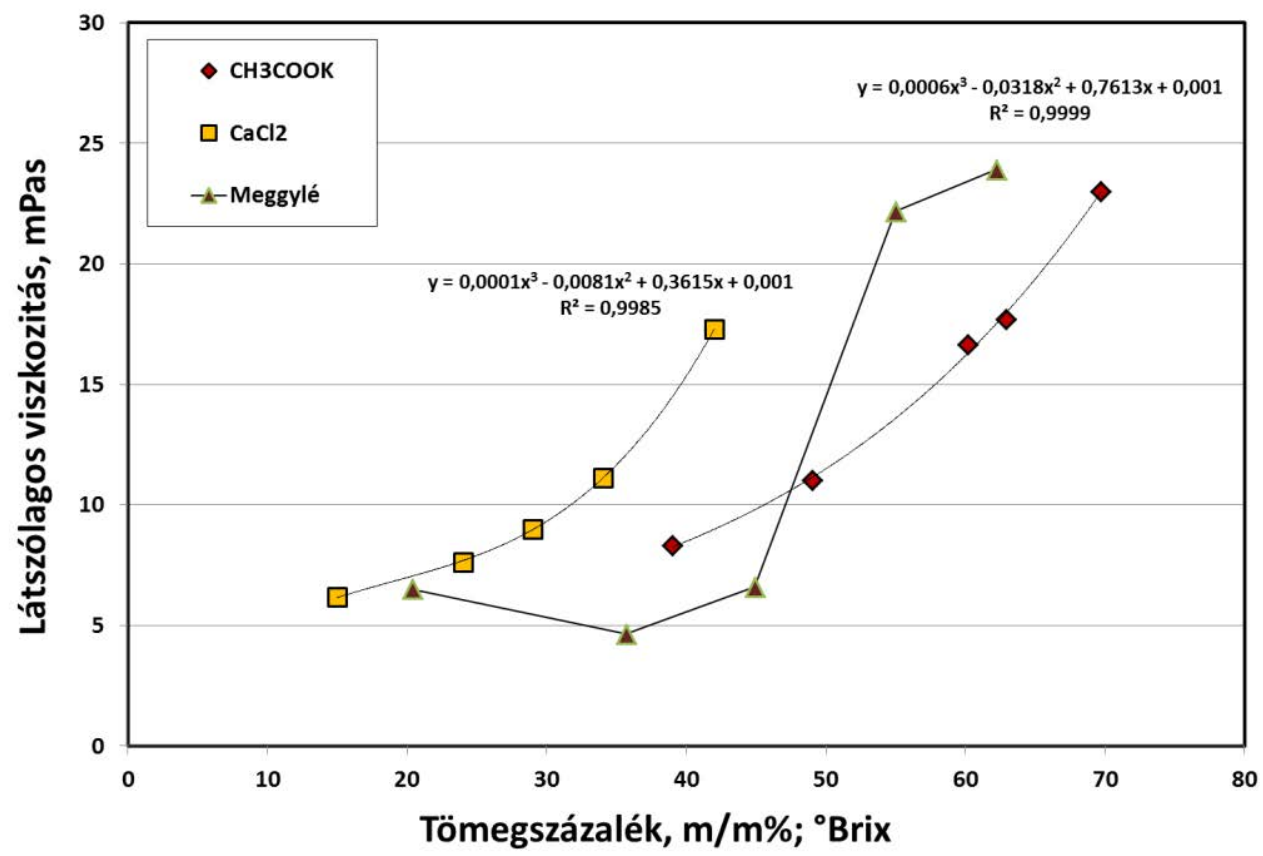


M.VIII. Statisztikai próbák táblázatai a meggysürítés folyamatában - táblázat szétszedése

ANOVA

\begin{tabular}{|ll|r|r|r|r|r|}
\hline & & \multicolumn{1}{|c|}{$\begin{array}{c}\text { Sum of } \\
\text { Squares }\end{array}$} & df & Mean Square & \multicolumn{1}{c|}{ F } & Sig. \\
\hline Antioxidáns_kapacitás & Between Groups & 70,623 & 7 & 10,089 & 16,201 &, 000 \\
& Within Groups & 49,820 & 80 &, 623 & & \\
& Total & 120,443 & 87 & & & \\
Összes_polifenol & Between Groups & 302,118 & 7 & 43,160 & 354,721 &, 000 \\
& Within Groups & 10,220 & 84 &, 122 & & \\
& Total & 312,339 & 91 & & & \\
& & &
\end{tabular}

Games-Howell

\begin{tabular}{|c|c|c|c|c|c|c|c|}
\hline $\begin{array}{l}\text { Dependent } \\
\text { Variable }\end{array}$ & (I) Kezelés & (J) Kezelés & $\begin{array}{c}\text { Mean Difference } \\
\text { (I-J) }\end{array}$ & Std. Error & Sig. & \multicolumn{2}{|c|}{$95 \%$ Confidence Interval } \\
\hline & & & & & & Lower Bound & Upper Bound \\
\hline \multirow{28}{*}{$\begin{array}{l}\text { Antioxidáns_ } \\
\text { kapacitás }\end{array}$} & \multirow{7}{*}{$\begin{array}{l}\text { Kiindulási } \\
\text { meggylé }\end{array}$} & MF szürlet &,- 0328338 & 1598454 & 1,000 &,- 589886 & ,524218 \\
\hline & & Spirál RO sürítmény & 2371662 & 1520616 & ,765 &,- 305431 & ,779763 \\
\hline & & Lap RO sủrítmény & 1,2160680 & 6035875 &, 510 &,- 960054 & 3,392190 \\
\hline & & K-acetát & $1,0715487\left(^{*}\right)$ & , 1794953 & ,000 & ,454618 & 1,688480 \\
\hline & & $\mathrm{CaCl} 2$ & $1,1843398\left({ }^{*}\right)$ & , 1453278 &, 000 & 650836 & 1,717843 \\
\hline & & Nh4No3 & $1,9460912(*)$ & , 1451601 & ,000 & 1,412754 & 2,479428 \\
\hline & & $\mathrm{K} 2 \mathrm{Co} 3$ & $2,6944398(*)$ & ,1461678 &, 000 & 2,159966 & 3,228914 \\
\hline & \multirow[t]{6}{*}{ MF szürlet } & Kiindulási meggylé &, 0328338 & (1598454 & 1,000 &,- 524218 & ,589886 \\
\hline & & Spirál RO sürítmény & 2700000 & 0930900 & ,125 &,- 043958 & ,583958 \\
\hline & & $\begin{array}{l}\text { Lap RO sủrítmény } \\
\text { K-acetát }\end{array}$ & $\begin{array}{r}1,2489019 \\
1043826(*)\end{array}$ & $\begin{array}{r}, 5914904 \\
1332725\end{array}$ & $\begin{array}{l}, 461 \\
000\end{array}$ & $\begin{array}{r}-, 913734 \\
629066\end{array}$ & $\begin{array}{l}3,411538 \\
1,579700\end{array}$ \\
\hline & & $\mathrm{CaCl} 2$ & $1,2171736(*)$ & 0816282 & ,000 & ,932721 & 1,501626 \\
\hline & & Nh4No3 & $1,9789250(*)$ & 0813293 & ,000 & 1,695062 & 2,262788 \\
\hline & & $\mathrm{K} 2 \mathrm{Co} 3$ & $2,7272736(*)$ & ,0831147 &, 000 & 2,439257 & 3,015290 \\
\hline & \multirow[t]{7}{*}{$\begin{array}{l}\text { Spirál RO } \\
\text { sürítmény }\end{array}$} & Kiindulási meggylé &,- 2371662 & 1520616 & ,765 &,- 779763 & ,305431 \\
\hline & & MF szürlet &,- 2700000 & (0930900 & ,125 &,- 583958 & ,043958 \\
\hline & & Lap RO sürítmény & 9789019 & ,5894345 & ,710 & $-1,181841$ & 3,139645 \\
\hline & & K-acetát &, $8343826(*)$ & , 1238294 & ,001 & ,375086 & 1,293679 \\
\hline & & $\mathrm{CaCl} 2$ &, $9471736(*)$ & 0650794 & ,000 & ,722795 & 1,171553 \\
\hline & & Nh4No3 & $1,7089250(*)$ & 0647041 & ,000 & 1,485428 & 1,932422 \\
\hline & & $\mathrm{K} 2 \mathrm{Co} 3$ & $2,4572736\left(^{*}\right)$ & ,0669344 & ,000 & 2,227395 & 2,687153 \\
\hline & \multirow{7}{*}{$\begin{array}{l}\text { Lap RO } \\
\text { sürítmény }\end{array}$} & Kiindulási meggylé & $-1,2160680$ & 6035875 & ,510 & $-3,392190$ & ,960054 \\
\hline & & MF szürlet & $-1,2489019$ & (5914904 & ,461 & $-3,411538$ & ,913734 \\
\hline & & Spirál RO sürítmény &,- 9789019 & ,5894345 &, 710 & $-3,139645$ & 1,181841 \\
\hline & & K-acetát &,- 1445193 & 5971004 & 1,000 & $-2,313179$ & 2,024141 \\
\hline & & $\mathrm{CaCl} 2$ &,- 0317282 & ,5877333 & 1,000 & $-2,190986$ & 2,127530 \\
\hline & & Nh4No3 & ,7300232 & -5876919, & 902 & $-1,429199$ & 2,889246 \\
\hline & & $\mathrm{K} 2 \mathrm{Co} 3$ & 1,4783718 & (5879416 & ,280 &,- 681065 & 3,637808 \\
\hline & K-acetát & Kiindulási meggylé & $-1,0715487(*)$ & ,1794953 & ,000 & $-1,688480$ &,- 454618 \\
\hline
\end{tabular}


MELLÉKLETEK

\begin{tabular}{|c|c|c|c|c|c|c|c|}
\hline & & MF szürlet & $-1,1043826(*)$ & ,1332725 & ,000 & $-1,579700$ &,- 629066 \\
\hline & & Spirál RO sürítmény &,$- 8343826(*)$ & ,1238294 & ,001 & $-1,293679$ &,- 375086 \\
\hline & & Lap RO sürítmény &, 1445193 & 5971004 & 1,000 & $-2,024141$ & 2,313179 \\
\hline & & $\mathrm{CaCl} 2$ &, 1127911 & ,1154606 & ,966 &,- 339774 &, 565356 \\
\hline & & Nh4No3 & ,8745424(*) & ,1152495 & ,001 & ,421999 & 1,327086 \\
\hline & & $\mathrm{K} 2 \mathrm{Co} 3$ & $1,6228910(*)$ &, 1165162 &, 000 & 1,169904 & 2,075878 \\
\hline & $\mathrm{CaCl} 2$ & Kiindulási meggylé & $-1,1843398(*)$ & , 1453278 & ,000 & $-1,717843$ &,- 650836 \\
\hline & & MF szürlet & $-1,2171736(*)$ & ,0816282 &, 000 & $-1,501626$ &,- 932721 \\
\hline & & Spirál RO sürítmény &,$- 9471736(*)$ & ,0650794 &, 000 & $-1,171553$ &,- 722795 \\
\hline & & Lap RO sűrítmény &, 0317282 &, 5877333 & 1,000 & $-2,127530$ & 2,190986 \\
\hline & & K-acetát &,- 1127911 & ,1154606 & ,966 &,- 565356 & ,339774 \\
\hline & & Nh4No3 &, $7617514(*)$ &, 0467338 &, 000 &, 605712 & 917790 \\
\hline & & $\mathrm{K} 2 \mathrm{Co} 3$ & $1,5101000(*)$ & ,0497759 & ,000 & 1,341581 & 1,678619 \\
\hline & NH4NO3 & Kiindulási meggylé & $-1,9460912(*)$ &, 1451601 &, 000 & $-2,479428$ & $-1,412754$ \\
\hline & & MF szürlet & $-1,9789250(*)$ & 0813293 & ,000 & $-2,262788$ & $-1,695062$ \\
\hline & & Spirál RO sürítmény & $-1,7089250(*)$ & 0647041 & ,000 & $-1,932422$ & $-1,485428$ \\
\hline & & Lap RO sürítmény &,- 7300232 & ,5876919 & ,902 & $-2,889246$ & 1,429199 \\
\hline & & K-acetát &,$- 8745424(*)$ &, 1152495 & ,001 & $-1,327086$ &,- 421999 \\
\hline & & $\mathrm{CaCl} 2$ &,$- 7617514(*)$ &, 0467338 &, 000 &,- 917790 &,- 605712 \\
\hline & & $\mathrm{K} 2 \mathrm{Co} 3$ &, $7483486(*)$ & ,0492842 &, 000 & ,581328 & ,915369 \\
\hline & $\mathrm{K} 2 \mathrm{CO} 3$ & Kiindulási meggylé & $-2,6944398(*)$ & , 1461678 &, 000 & $-3,228914$ & $-2,159966$ \\
\hline & & MF szürlet & $-2,7272736(*)$ & 0831147 &, 000 & $-3,015290$ & $-2,439257$ \\
\hline & & Spirál RO sürítmény & $-2,4572736(*)$ &, 0669344 & ,000 & $-2,687153$ & $-2,227395$ \\
\hline & & Lap RO sürítmény & $-1,4783718$ & ,5879416 & ,280 & $-3,637808$ & ,681065 \\
\hline & & K-acetát & $-1,6228910(*)$ & ,1165162 & ,000 & $-2,075878$ & $-1,169904$ \\
\hline & & $\mathrm{CaCl} 2$ & $-1,5101000(*)$ & ,0497759 &, 000 & $-1,678619$ & $-1,341581$ \\
\hline & & Nh4No3 &,$- 7483486(*)$ &, 0492842 &, 000 &,- 915369 &,- 581328 \\
\hline Összes_polife & $\begin{array}{l}\text { Kiindulási } \\
\text { meogvlé }\end{array}$ & MF szürlet & $2,0849609(*)$ & ,1209254 & ,000 & 1,677469 & 2,492453 \\
\hline & & Spirál RO sürítmény & $3,0497234(*)$ & ,1499832 & ,000 & 2,547896 & 3,551551 \\
\hline & & Lap RO sürítmény & $2,6222522(*)$ & ,1424628 &, 000 & 2,146460 & 3,098044 \\
\hline & & K-acetát & $4,3905343(*)$ & , 1957448 &, 000 & 3,720969 & 5,060099 \\
\hline & & $\mathrm{CaCl} 2$ & $4,3950936(*)$ &, 1311732 & ,000 & 3,954930 & 4,835257 \\
\hline & & Nh4No3 & $5,2416655(*)$ &, 1150123 &, 000 & 4,847984 & 5,635347 \\
\hline & & $\mathrm{K} 2 \mathrm{Co} 3$ & $5,9936713(*)$ & , 1078668 &, 000 & 5,618709 & 6,368633 \\
\hline & MF szürlet & Kiindulási meggylé & $-2,0849609(*)$ &, 1209254 & ,000 & $-2,492453$ & $-1,677469$ \\
\hline & & $\begin{array}{l}\text { Spiral RU suritmeny } \\
\text { Lap RO sürítmény }\end{array}$ & $\begin{array}{l}, 9647625(*) \\
, 5372913(*)\end{array}$ & ,1340599 & $\begin{array}{l}, 000 \\
, 008\end{array}$ & $\begin{array}{l}, 508 / 85 \\
, 112701\end{array}$ & $\begin{array}{r}1,420 / 40 \\
, 961882\end{array}$ \\
\hline & & K-acetát & $2,3055733(*)$ & ,1838291 &, 000 & 1,661902 & 2,949245 \\
\hline & & $\mathrm{CaCl} 2$ & $2,3101327(*)$ & ,1126211 &, 000 & 1,929953 & 2,690312 \\
\hline & & Nh4No3 & $3,1567046(*)$ & ,0933002 &, 000 & 2,840404 & 3,473005 \\
\hline & & $\mathrm{K} 2 \mathrm{Co} 3$ & $3,9087103(*)$ & ,0843348 & ,000 & 3,622290 & 4,195131 \\
\hline & $\begin{array}{l}\text { Spirál RO } \\
\text { sürítmény }\end{array}$ & Kiindulási meggylé & $-3,0497234(*)$ & , 1499832 &, 000 & $-3,551551$ & $-2,547896$ \\
\hline & & MF szürlet &,$- 9647625(*)$ & ,1340599 &, 000 & $-1,420740$ &,- 508785 \\
\hline & & Lap RO sürítmény &,- 4274712 & ,1537685 &, 152 &,- 941292 & ,086349 \\
\hline & & K-acetát & $1,3408108(*)$ & ,2041204 &, 000 & ,649733 & 2,031889 \\
\hline & & $\mathrm{CaCl} 2$ & $1,3453702(*)$ & , 1433719 & ,000 &, 862327 & 1,828413 \\
\hline & & Nh4No3 & $2,1919421\left({ }^{*}\right)$ &, 1287514 & ,000 & 1,747307 & 2,636577 \\
\hline & & $\mathrm{K} 2 \mathrm{Co} 3$ & $2,9439479(*)$ & ,1224106 &, 000 & 2,513930 & 3,373965 \\
\hline & Lap RO & Kiindulási meggylé & $-2,6222522(*)$ &, 1424628 &, 000 & $-3,098044$ & $-2,146460$ \\
\hline
\end{tabular}


sürítmény
MF szürlet

Spirál RO sürítmény

K-acetát

$\mathrm{CaCl} 2$

Nh4No3

$\mathrm{K} 2 \mathrm{Co} 3$

Kiindulási meggylé

MF szürlet

Spirál RO sürítmény

Lap RO sürítmény

$\mathrm{CaCl} 2$

Nh4No3

$\mathrm{K} 2 \mathrm{Co} 3$

Kiindulási meggylé MF szürlet

Spirál RO sürítmény

Lap RO sürítmény

K-acetát

Nh4No3

$\mathrm{K} 2 \mathrm{Co} 3$

Nh4No3

Kiindulási meggylé

MF szürlet

Spirál RO sürítmény

Lap RO sürítmény

K-acetát

$\mathrm{CaCl} 2$

$\mathrm{K} 2 \mathrm{Co} 3$

$\mathrm{K} 2 \mathrm{Co} 3$

Kiindulási meggylé

MF szürlet

Spirál RO sürítmény

Lap RO sürítmény

K-acetát

$\mathrm{CaCl} 2$

Nh4No3

\begin{tabular}{|c|c|}
\hline,$- 5372913(*)$ & ,1255896 \\
\hline ,4274712 &, 1537685 \\
\hline $1,7682820(*)$ &, 1986600 \\
\hline $1,7728414(*)$ &, 1354850 \\
\hline $2,6194133(*)$ & ,1199066 \\
\hline $3,3714191(*)$ & ,1130709 \\
\hline$-4,3905343(*)$ & ,1957448 \\
\hline$-2,3055733\left({ }^{*}\right)$ & ,1838291 \\
\hline$-1,3408108(*)$ & ,2041204 \\
\hline$-1,7682820(*)$ &, 1986600 \\
\hline, 0045594 & ,1907264 \\
\hline, $8511313(*)$ & ,1799944 \\
\hline $1,6031370(*)$ &, 1755147 \\
\hline$-4,3950936(*)$ & ,1311732 \\
\hline$-2,3101327(*)$ &, 1126211 \\
\hline$-1,3453702(*)$ & ,1433719 \\
\hline$-1,7728414(*)$ &, 1354850 \\
\hline,- 0045594 & ,1907264 \\
\hline, $8465719(*)$ &, 1062468 \\
\hline $1,5985776(*)$ & ,0984673 \\
\hline$-5,2416655(*)$ &, 1150123 \\
\hline$-3,1567046(*)$ & ,0933002 \\
\hline$-2,1919421(*)$ &, 1287514 \\
\hline$-2,6194133(*)$ & ,1199066 \\
\hline,$- 8511313(*)$ & ,1799944 \\
\hline,$- 8465719(*)$ &, 1062468 \\
\hline, $7520057(*)$ &, 0756123 \\
\hline$-5,9936713(*)$ &, 1078668 \\
\hline$-3,9087103(*)$ &, 0843348 \\
\hline$-2,9439479(*)$ & ,1224106 \\
\hline$-3,3714191(*)$ & ,1130709 \\
\hline$-1,6031370(*)$ &, 1755147 \\
\hline$-1,5985776(*)$ & ,0984673 \\
\hline,$- 7520057(*)$ &, 0756123 \\
\hline
\end{tabular}

$-, 112701$

,941292

2,445073

2,227951

3,031150

3,766080

$-3,720969$

$-1,661902$

$-, 649733$

$-1,091491$

,663003

1,488602

2,233295

$-3,954930$

$-1,929953$

$-, 862327$

$-1,317732$

, 653885

1,211551

1,942109

$-4,847984$

$-2,840404$

$-1,747307$

$-2,207677$

$-, 213661$

$-, 481593$

1,014018

$-5,618709$

$-3,622290$

$-2,513930$

$-2,976758$

$-, 972979$

$-1,255046$

$-, 489994$

* The mean difference is significant at the .05 level. 


\section{Köszönetnyilvánítás}

Ezúton szeretném megköszönni témavezetöimnek, Dr. Vatai Gyulának és

Dr. Kovács Zoltánnak munkám alatt és dolgozatom elkészítésében nyújtott áldozatkész segitségüket.

Szeretném megköszönni az Élelmiszeripari Müveletek és Gépek Tanszék dolgozóinak, köztük Békássyné dr. Molnár Erikának, Dr. Csury Istvánnak, Dr. Márki Editnek, Dr. Koris Andrásnak, Dr. Bánvölgyi Szilviának, Dr. Fogarassy Eszternek, Köszegi Lászlónénak, Gáspár Igornak, Gudor Enikőnek, a volt és jelenlegi PhD hallgatóknak, Albert Krisztinának, Verasztó Balázsnak, Molnár Máténak az évek alatt nyújtott sok-sok segitséget és a közös munkát.

Továbbá köszönöm Mehmet Torunnak, Franku Tamásnak, MD Rizvi Alamnak és Chetana Kumarnak a lelkiismeretes és kitartó munkájukat a szak-ill. diplomadolgozatuk elkészitése során.

Köszönöm az Alkalmazott Kémia Tanszék dolgozóinak, Stefanovitsné dr. Bányai Évának, Papp Nórának és Hanek Ferencének a sok-sok türelmet és segitséget.

Dolgozatom nem jöhetett volna a THM-IBPT dolgozóinak és diákjainak a segítsége nélkül. Köszönöm Prof. Dr. Peter Czermak és Mehrdad Ebrahimi témavezetőknek, és az Intézet munkatársainak és hallgatóinak, hogy mindig fordulhattam hozzájuk bármilyen kérdéssel.

Végül szeretném megköszönni Édesanyámnak, Édesapámnak, Testvéremnek és családjának, és Barátaimnak, hogy mindig pozitívan álltak céljaimhoz és támogattak azok elérésében. 